\title{
KIWICÎTOWEK INSINIWUK: NEHINUW GOVERNANCE IN NEHINUW TERMS
}

\author{
by \\ Réal Carrière \\ Bachelor of Arts, 2006, Simon Fraser University \\ Master of Public Administration, 2010, University of Regina \\ A dissertation \\ presented to Ryerson University \\ in partial fulfillment of the \\ requirements for the degree of \\ Doctor of Philosophy \\ in the program of \\ Policy Studies
}

Toronto, Ontario, Canada, 2018

(C) Réal Carrière, 2018 


\section{AUTHOR'S DECLARATION FOR ELECTRONIC SUBMISSION OF A DISSERTATION}

I hereby declare that I am the sole author of this dissertation. This is a true copy of the dissertation, including any required final revisions, as accepted by my examiners.

I authorize Ryerson University to lend this dissertation to other institutions or individuals for the purpose of scholarly research.

I further authorize Ryerson University to reproduce this dissertation by photocopying or by other means, in total or in part, at the request of other institutions or individuals for the purpose of scholarly research.

I understand that my dissertation may be made electronically available to the public. 


\begin{abstract}
KIWICITTOWEK INSINIWUK: NEHINUW GOVERNANCE IN NEHINUW TERMS

Ph.D., 2018, Réal Carrière, Policy Studies, Ryerson University

Indigenous nations have diverse, complex, and ancient governance theories and practices,
\end{abstract} yet settler governments have consistently tried to eliminate these theories and practices. Despite the objectives of colonization, Indigenous people have maintained the knowledge of Indigenous governance. To understand Indigenous governance, an effort must be made to understand these theories from a specific Indigenous worldview. In other words, what is Indigenous governance in Indigenous terms? This dissertation aims to address this question by exploring governance through the knowledge of the Nehinuw by asking, what does Nehinuw knowledge teach us about Nehinuw governance? To understand Nehinuw governance from a Nehinuw worldview, the author researched using a Nehinuw theoretical framework which included specific Nehinuw research methods and a method analysis based on the Nehinuw concept of Nistotên (to understand). The findings of this dissertation consider the complexity and diversity of Nehinuw governance theory and practice that challenge mainstream perspectives of Indigenous governance and provide valuable lessons for policymakers that work in the field of Indigenous governance. The outcome of this dissertation fills more than a gap in the literature because using the Nehinuw theoretical framework has enabled me to empower the communities covered in this dissertation, and develop, in partnership with local educators, educational resources on Nehinuw governance that can and will be used by the community to educate future generations on Nehinuw governance and become the foundation of future scholarly research and practice. Keywords: Indigenous Governance, Indigenous Knowledge, Nehinuw Governance, Nehinuw Knowledge. 


\section{Acknowledgements}

Before I tell you about this dissertation, I want to acknowledge the people, places, and spirits that have helped me get to where I am today. I would like to acknowledge the land, water, and sky. I am honoured that I can say I grew up on the land. The land has taught me so much and I inspire to protect you for future generations.

I would like to acknowledge my family. You have helped me become the person that I am today. I try to honour and protect the knowledge of my ancestors. I was lucky to have met all my grandparents and my grandmothers are still with me. Nimosom Bill took me out on the land and told me about the ways of our ancestors. He taught me to be patient. My Opa John passed away before we went back to his homeland, but he was always a great spirit. He taught me to laugh. Nokom Josie has always been a great storyteller. I like to begin conversations with her by asking about her past. Tell me about Amisk Lake. My Oma Evadne, you have always been there for me, helping and guiding me throughout my life. You would hold my hand while I fell asleep beside your bed and you would help edit my papers. You taught me to enjoy life. To my mother Renée, we have had many debates. I think you taught me to be critical and passionate. To my father Solomon, we have spent a lot of time on the land. You taught the meaning of hard work even though I never listen. To my sisters Jacqueline, Michela, and Martina, you have helped me so much. Shh. Be quiet. Go feed dogs. To my wife Lori, I love you. To my children, I am excited to see your future. I want to pass on the knowledge of our ancestors to you and future generations. I try to be everything you have taught me and I love you with all my heart.

I would like to acknowledge the support of my participants including Keith Goulet, Stan Wilson, Solomon Carrière, Edwin Jebb, Pauline McKay, William Lathlin, Glen Ross, John 
Carriere, Frank Whitehead, and others. I also want to acknowledge the leadership of the Northern Village of Cumberland House, Cumberland House Cree Nation, and Opaskwayak Cree Nation for their guidance and allowing me to conduct this dissertation on your land and with your knowledge keepers. I appreciate the knowledge you shared with me and it will help future generations learn about our knowledge.

I would like to thank my dissertation committee. To Dr. Lynn Lavallée, as my supervisor you have always helped me see the bigger picture. I am honoured that I got to know you and work with you during this difficult time. To Dr. Pamela Palmater, you have been an invaluable mentor. You inspired me to come to Ryerson. You have helped me see the small details with an extremely critical eye. I don't know how I would have made it this far without your guidance. To Dr. Carolyn Johns, I appreciate all the positive encouragement you gave me over the years and challenged me to see the alternative perspectives. To Dr. Joanne DiNova, I am grateful for your detailed comments on my dissertation. To Dr. Sheryl Lightfoot, I appreciated your thought provoking comments on my work.

I want to acknowledge the funders of this dissertation. I want to thank my supervisor Dr. Lynn Lavallée for suggesting an avenue of funding, the Canadian Institutes of Health Research, Institute of Aboriginal Peoples' Health, and Health Canada - First Nations and Inuit Health Branch \#CIHR-AHI 120532, and the Active Circle Research Project team for accepting my dissertation as part of your large project. Second, I want to thank the Ryerson Aboriginal Education Council for providing me with funds to conduct the field research. I would not have been able to complete this dissertation without your support.

I also want to acknowledge some other people that have helped me along my journey. To Dr. Theo Dombrowski, for always being there when I needed some advice and support. To Dr. 
Andrew Heard, thank you for inspiring me to pursue further studies. To Sonya Taccone, thank you for taking the time to look at my application even though it was late.

Finally, I would like to acknowledge the Creator. I believe that there is a reason to life and it has guided me to this dissertation and place. I am honoured to be working for my people to protect our knowledge.

Kinanâskomitinâwâw (I am grateful to you all). 


\section{Table of Contents}

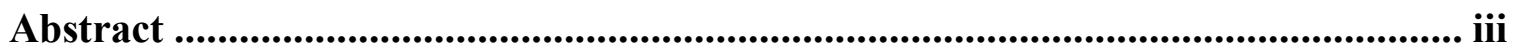

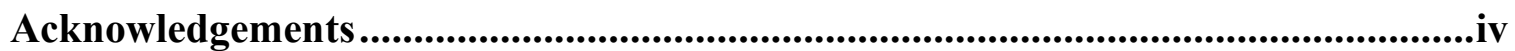

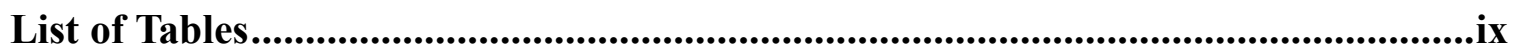

List of Figures ..............................................................................................................

List of Appendices ............................................................................................................

Chapter 1: Nitati-atoskan (I am starting to work).....................................................1

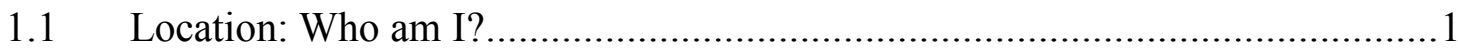

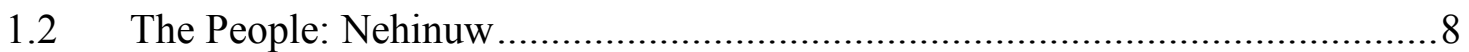

1.3 The Problem: What is Indigenous Governance? …………….......................17

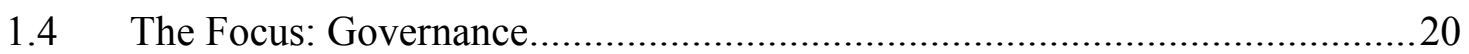

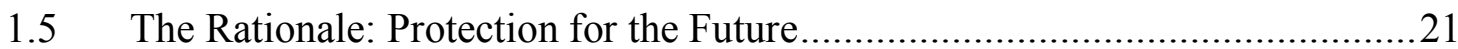

1.6 The Approach: Nehinuw Research Paradigm...............................................25

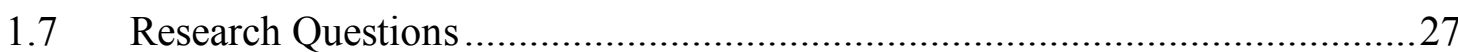

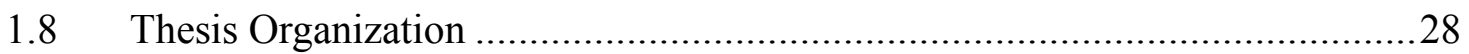

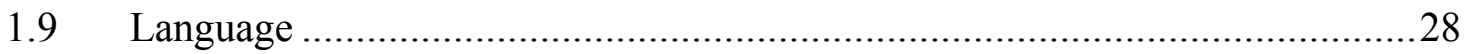

Chapter 2: Kiskinaumasowin (Teaching yourself) .......................................................32

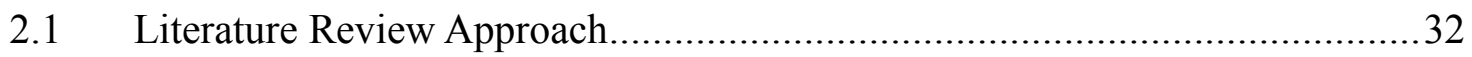

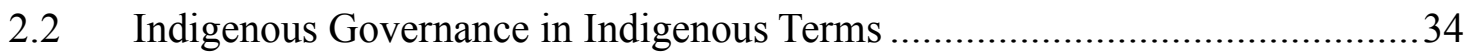

2.3 Colonization: Dispossession, Oppression, and Dependency...........................54

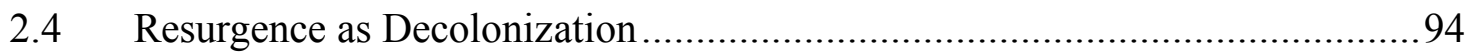

Chapter 3: Weechihitowin (Helping each other)...........................................................104

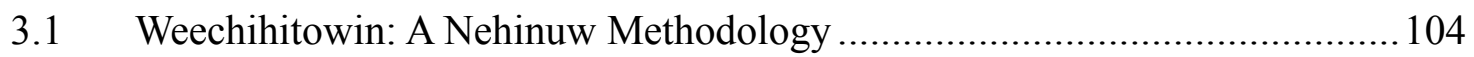

3.2 Weetumatowin: Nehinuw Knowledge Gathering and Research Design......... 113

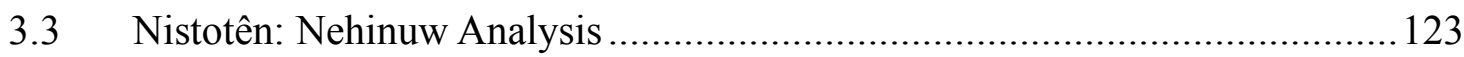

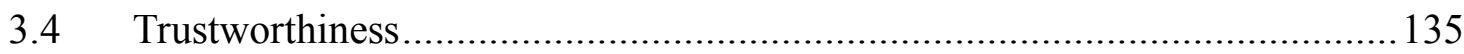

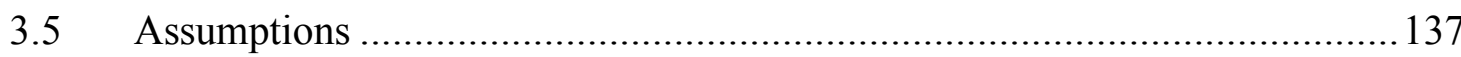

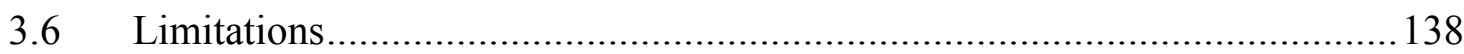

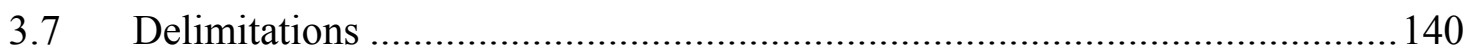

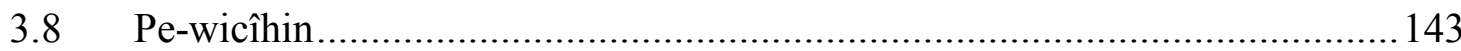

Chapter 4: Weetumatowin (Sharing stories) ...................................................................145

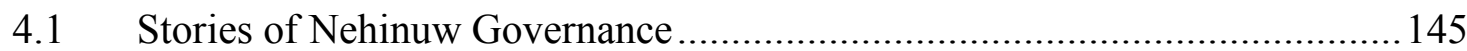

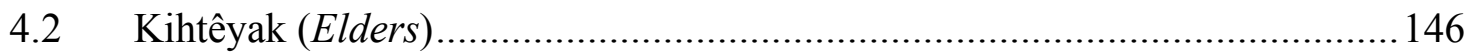

4.3 Kiwicîtowek Insiniwuk (Helping/working together)................................... 152 


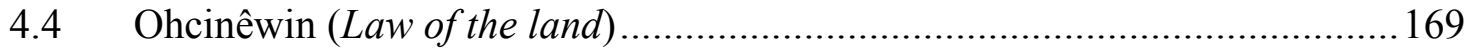

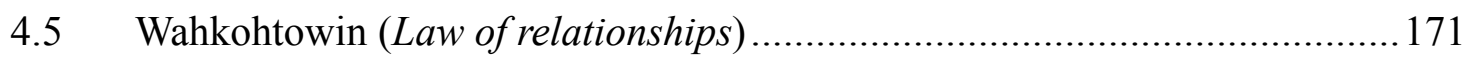

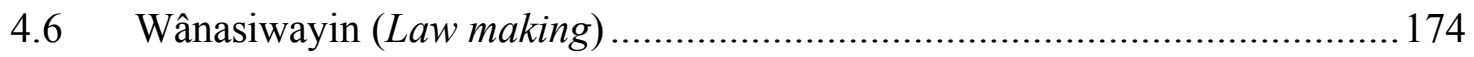

4.7 Askîwipimâcihowascikêwina (Livelihood agreements)..................................177

4.8 Âcimowin (Storytelling)......................................................................... 179

4.9 Okimâwiwaywin (Leadership law).......................................................... 181

4.10 Ininisihcikewin (People ceremony/way of life) ............................................. 187

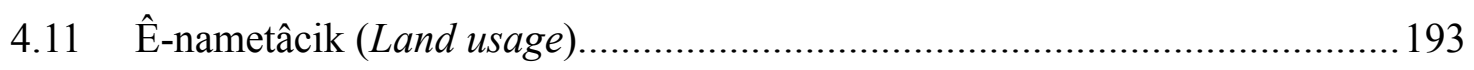

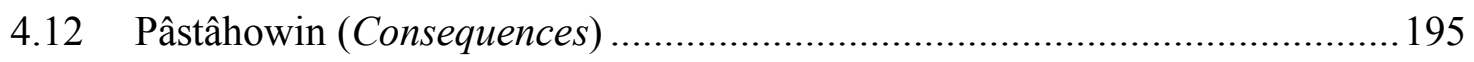

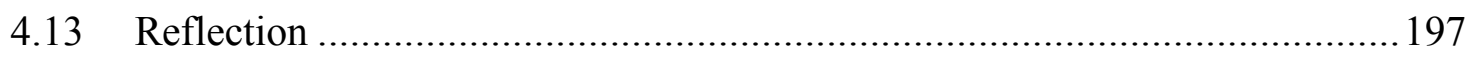

Chapter 5: Kinistotên? (Do you understand?) ............................................................198

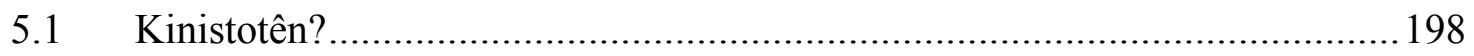

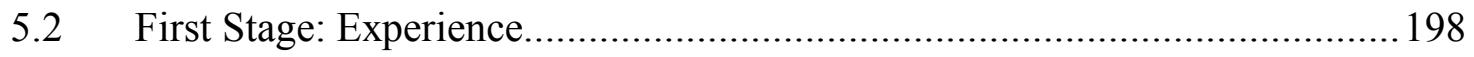

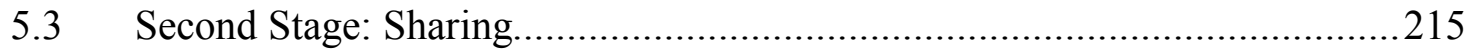

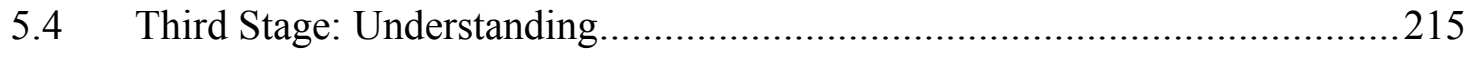

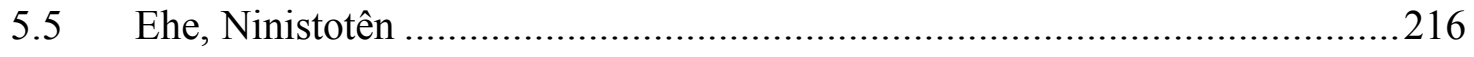

Chapter 6: Miskâsowin (Finding yourself) ...................................................................218

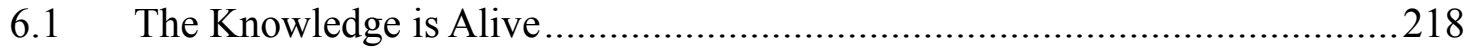

6.2 Glossary of Nehinuw Governance Theories and Practices .............................221

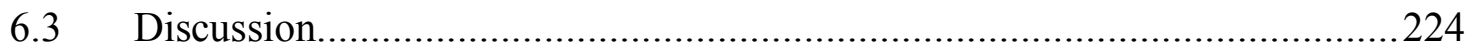

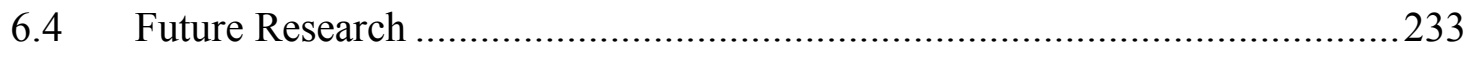

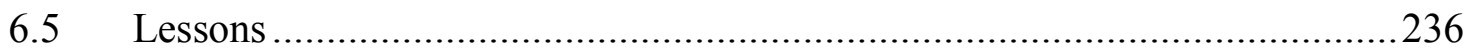

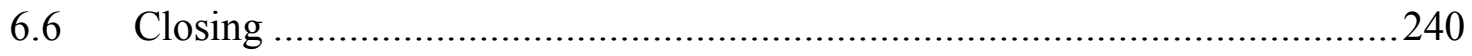

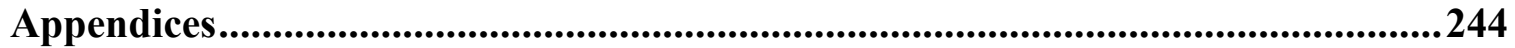

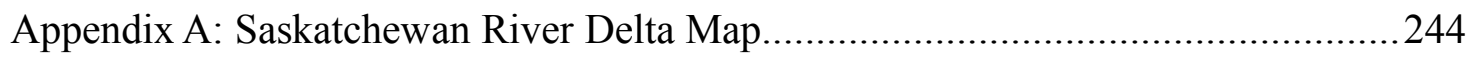

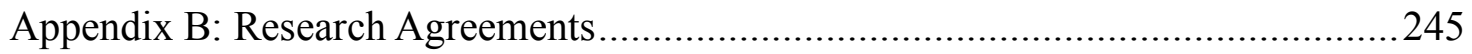

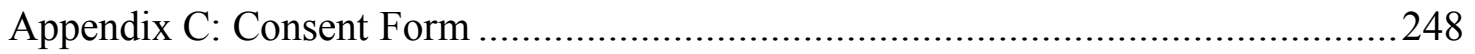

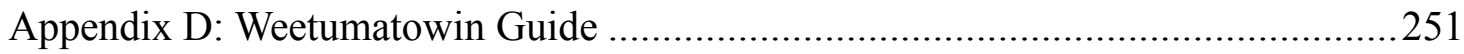

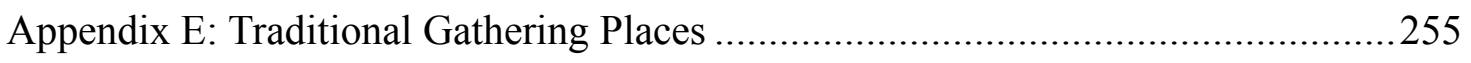

Appendix F: Additional Cree Governance Theories and Practices............................256

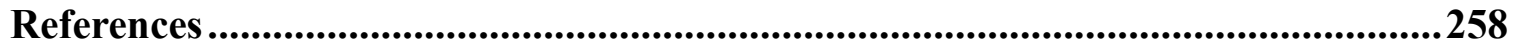




\section{List of Tables}

Table 1.1. Glossary of Nehinuw Governance Theories and Practices 222

Table 1.2. Additional Cree Governance Theories and Practices 256 


\section{List of Figures}

Figure 1.1. Interconnection of Nehinuw legal systems 210 


\section{List of Appendices}

Appendix A Saskatchewan River Delta Map 244

$\begin{array}{lll}\text { Appendix B Research Agreements } & 245\end{array}$

$\begin{array}{lll}\text { Appendix C Consent Form } & 248\end{array}$

$\begin{array}{lll}\text { Appendix D Weetumatowin Guide } & 251\end{array}$

$\begin{array}{lll}\text { Appendix E } & \text { Traditional Gathering Places } & 255\end{array}$

Appendix F Additional Cree Governance Theories and Practices 256 


\section{Chapter 1: Nitati-atoskan (I am starting to work)}

\subsection{Location: Who am I?}

Tansi, Réal Carrière nitisinikason. Nina Nehinuw napew. Mistapikmawak ochi nina ekwa nitati-atoskan. Hello, my name is Réal Carrière. I am a Cree man. I am from Big Eddy and I am starting to work. I want to begin this dissertation by telling you who I am.

Absolon and Willett (2005) argue that Indigenous researchers should begin their research by locating oneself. When you locate yourself, you state who you are, where you are from, and how this influences your research (Absolon, 2011). Location is more than the integration of Indigenous protocols into academia (Lavallée, 2009). Indigenous academics have identified numerous theoretical and practical benefits of location. Location empowers Indigenous research (Kovach, 2009; Wilson, 2007); recognizes individual growth (Lavallée, 2009); situates the researcher within the academic world of knowledge creation (Absolon \& Willett, 2004); accounts for Indigenous oral traditions (Absolon, 2011; Wheeler, 2010); and identifies the researcher as an "authentic researcher" that is part of the community (Swisher, 1986) focused on benefiting the community (Ermine, Sinclair \& Jeffery, 2004). I see location as the first step in establishing the theoretical framework of this dissertation; it allows me to state who I am and how this has influenced the topic, methodology, and intentions of my dissertation.

It has taken me a long time to understand who I am. My mother, Renée Merz, was born and raised in Saskatoon, Saskatchewan, Treaty 6 territory. She has a mixture of English and German ancestry. Her mother was born in Canada. Her maternal grandfather immigrated to Canada from England in 1912. Her maternal grandmother was a second-generation immigrant with roots in England. Her father immigrated to Saskatoon, Saskatchewan from Germany in 
1953 following the Second World War. My father, Solomon Carrière, was born and raised in Cumberland House, Saskatchewan. He has a mixture of Métis, Scottish, French, Nehinuw, Saulteaux, and Nethinaw ancestry. Despite my complex ancestry, I identify with my Father's cultural heritage, which is largely Nehinuw, since I grew up on Nehinuw territory and was immersed in Nehinuw culture. I want to thank my mother for making the decision to raise her family on the land. I know you have had a difficult time being accepted by the community, but if you had not made the decision to move out to Nehinuw territory, I would not be the person I am today. I am a Nehinuw man. No matter where I am, I try to honour the values and traditions of my ancestors.

Since Canadian law and policy has interfered with Indigenous citizenship theories and practices (Andersen, 2014; Palmater, 2011a), I want to take you on the journey I went through to identify as Nehinuw because this journey influences what I studied and how I designed this dissertation. First, I thought that I was Métis because I have mixed Indigenous and nonIndigenous genealogy. Additionally, since I was not officially recognized by the Indian Act, as either status Indian or band member, I felt that I must be Métis. In other words, I thought that to be mixed and unrecognized was to be Métis. Many people identify as Métis because they have mixed Indigenous/Non-Indigenous ancestry and no official recognition under the Indian Act (Andersen, 2014; Nickel, 2014). However, I now understand that Métis-as-mixed is problematic because the Métis-as-mixed narrative ignores who the Métis are as Indigenous people and their unique social, political and cultural genesis (Andersen, 2014). Furthermore, the Indian Act does not represent Indigenous citizenship theories and practices (Andersen, 2014; Innes, 2013; Lawrence, 2004; Lee, 2015; Palmater, 2011a). Reflecting on my Métis identity and Métis scholarship, Métis identity in my home territory has largely been created in response to Canadian 
Indigenous identity policy, which has divided the Nehinuw into status and non-status Indians, and many outsiders refer to themselves as Métis rather than having an actual connection to the Métis people. I would like to explore this further in a future paper; but I have moved away from identifying as Métis because I misunderstood what it meant to be Métis.

Second, I thought if I was not Métis then I must be Aboriginal. The Canadian Constitution defines three categories of Aboriginal people including Indian, Métis, and Inuit. However, Aboriginal is an English term. Furthermore, Aboriginal was designed by the Canadian government to assimilate Indigenous citizenship theories and practices (Aboriginal Justice Inquiry of Manitoba, 1999; Alfred \& Corntassel, 2005; Alfred, 2009b; Andersen, 2014; Lee, 2015; Palmater, 2011a, 2013; Simpson, 2008c). Furthermore, it is impossible to be Aboriginal because this term includes three, if not hundreds of mutually exclusive people (Andersen, 2014). As I reflected upon the meaning and history of the term "Aboriginal", I decided not to use this term because I do not want to assimilate. I want to support the intellectual diversity of Aborignal peoples and the term Aboriginal does nothing but homogenize our knowledge.

In rejecting Aboriginal, I began to use the term "Indigenous", which had received recognition in the United Nations Declaration on the Rights of Indigenous Peoples (UNDRIP) (United Nations, 2007). UNDRIP, which provides a comprehensive framework for the recognition of Indigenous people in international law, was a major accomplishment for Indigenous people (Davis, 2008) that reinforces Indigenous legal orders (Henderson, 2008b) and challenges international politics by making room for Indigneous rights (Lightfoot, 2016). Yet, there are concerns that UNDRIP “distracts us from our real priorities” (Corntassel, 2012a, p.93) and creates conflicts between collective and individual rights (Belanger, 2011). Despite the strengths and weaknesses of the declaration, UNDRIP did provide international recognition of 
Indigenous peoples and rights. However, when I reflected on my usage of the term Indigenous, I realized that the term has a similar homogenous effect as Aboriginal, which I had rejected for this point. As Corntassel (2003) notes, there are multiple frameworks used to identify Indigenous peoples and many of these frameworks are not Indigenous. Thus, my need to recognize Indigenous identity in Indigenous terms grew stronger throughout this dissertation as I read more on the diversity of Indigenous knowledge (Absolon, 2011; Battiste, 2000; Battiste \& Henderson, 2000; Grenier, 1998; Simpson, 2004; Wilson, 2007). This believe has evolved to the point that I use Indigenous terms, an example is the title of this dissertation, throughout my work and life. I say this because I have had the privilege of sharing knowledge and stories with many people from many Indigenous nations such as Apache, Dene, and Onkwehon:we. In each instance, I found myself learning about a unique worldview, the same way you would learn about different cultures if you travel across Europe. Therefore, I concluded that the only way to discuss my identity and the focus of this dissertation was to use a specific Indigenous term.

Since I decided to focus on the diversity of Indigenous political traditions and a specific Indigenous people, I thought it would be acceptable to use the English translation Cree or Swampy Cree. However, during the first year of my doctoral studies, I met the resident Elder at Ryerson University, Mr. Ed Sackaney. Mr. Sackaney told me he was a Muskegowuk Cree from Fort Albany, Ontario. I had known that the Cree had a vast territory stretching from Alberta to Quebec. Mandelbaum (1979) argues that the Cree migrated from Muskegowuk territory around James Bay into central Canada. Therefore, I was not surprised when he identified as a Cree person; but, his use of Muskegowuk was provocative. I know that Muskegowuk means swampy people. Mr. Sackaney translated Muskegowuk into "Swampy Cree". This definition posed a problem for my dissertation because Swampy Cree is the term that people use from my territory 
(Wilson, 1989), but I had not heard of the specific use of Muskegowuk. This broad view of the Swampy Cree is also supported in the literature (Okimasis, 2004; Paupanekis, 2008; Ratt, 2016; Wolvengrey, 2011). So, either we are the same group of people, or there are two Swampy Cree people. I answered this question as I got to know Mr. Sackaney. We shared stories about our people and I realized that we had different mythologies even though we both considered ourselves to be Cree. For example, Mr. Sackaney talked about hunting geese in the spring and I told him that my people hunt geese in the fall. At that moment, I knew that using Cree or any other English designation for Cree identity, such as Swampy Cree, was problematic. I needed to frame this dissertation around a specific Cree concept. I needed to know what term the Cree in my area use to refer to our identity.

Growing up I had heard multiple Cree terms, so I decided to consult with people from my community about the Cree name for our people to find a term that I could use in this dissertation. I began by consulting the respected Elder/Scholar Keith Goulet (Hansen, 2013). He is one of the first from the area to discuss the validity of Cree knowledge (Goulet, 1986) and he has published research on Cree pedagogy (Goulet \& Goulet, 2014). After consulting him, he provided the term Nehinuw. As he explained, Nehinuw is reference to the $\mathrm{N}$ dialect of Cree, which is spoken in my territory (Goulet \& Goulet, 2014). I reviewed language texts and resources to provide additional context. There are five dialects of Cree (Okimasis, 2004; Paupanekis, 2008; Ratt, 2016;

Wolvengrey, 2011) and the $\mathrm{N}$ dialect of Cree is one of these dialects. The $\mathrm{N}$ dialect refers to the group of Cree people that frequently use the N sound within the language (Wolvengrey, 2011). For example, the first-person pronoun Nina $(I)$ highlights the use of the $\mathrm{N}$ sound whereas in the Y dialect the same pronoun is said Niya. The difference between these dialects is not a simple as replacing specific sounds. Many different concepts, words, and phrases are used between the 
dialects (Ahenakew, 1987). N dialect Cree speakers are frequently referred to as Swampy Cree (Wolvengrey, 2011). However, I also realized that using one term is problematic because each person I consulted with used a slightly different term. I experienced what Brightman (1993) refers to as "relational identity". In his study of the Cree, he noted that the Cree people use different terms to discuss identity depending on context. The use of multiple terms posed an interesting intellectual problem for this dissertation. What is the appropriate layer to discuss Cree knowledge because the layers of Cree identity are so specific that identity can be defined on a continuum anywhere between international and family. I decided to use the broadest concept that was identified by several sources; however, I use Keith Goulet's spelling "Nehinuw". More research is needed to explore the complexities of Indigenous identity.

Once I identified the term Nehinuw, I used Nehinuw in all written forms related to my dissertation. I also use this term in my personal life, and I identify as Nehinuw even though according to Canadian law I am both non-status and Métis. I recognize the complexity of Nehinuw identity, and when I am talking to my people I use more specific terminology to discuss identity. Using Nehinuw provided the focus that I needed for this dissertation. If you would like to discuss my identity in further detail, elaborating on my identity is beyond the scope of this chapter and Ph.D. However, I could show you the extensive research my grandfather conducted in the early 90s when he applied for Indian status, which documented all my Indigenous ancestry. You could contact my community to ask them if they know who I am and that I am from this community. You can read the transcript of the Saskatchewan Legislative assembly that recognizes my accomplishments as a youth from Cumberland House (Legislative Assembly of Saskatchewan, 2000). I have some European-settler genealogy, I speak English, I do not fluently speak the Nehinuw language, but in my heart I am Nehinuw and I identify as such. I am 
Nehinuw. Nehinuw territory is in my dreams. The important thing is that I have designed this dissertation to protect Nehinuw knowledge for future generations by respecting the research and knowledge protocols of my Nehinuw ancestors.

Protection of Indigenous knowledge in academic research can be a controversial topic for Indigenous people. Research is not a neutral exploration of knowledge. Past research has exploited Indigenous people and knowledge (Smith, 2012). As a Nehinuw researcher, I have had a challenging time reconciling the tensions between western and Indigenous worldviews. On one hand, I am a Ph.D. candidate in a western post-secondary institution, expected to become an expert on a specific topic and to produce an original and comprehensive written source of knowledge (Dunleavy, 2003). In one of my first classes for my doctoral program, Dr. Mehrunnisa Ali described a Ph.D. as making the transition from knowledge consumer to producer. The Ph.D. process conflicted with my understanding of Nehinuw pedagogy. Indigenous knowledge is a collective body of oral knowledge (Chilisa, 2012; Ermine, Sinclair, \& Jeffery, 2004) and becoming an expert is a lifelong process (Kovach, 2009; Steinhauer-Hill, 2008). Relationships are fundamental to a Nehinuw pedagogy (Goulet \& Goulet, 2014; Wilson, 2008). I feel that I have reconciled these differences by centering this dissertation on Nehinuw research protocols. I describe the processes and protocols of this dissertation in Chapter 3. I followed these processes and protocols because there is less of a tension between academia and Indigenous worldviews when the researcher follows an Indigenous research paradigm. Thus, I feel that I have been successful in designing a dissertation that has helped me learn about my people, gain a deeper understanding of Nehinuw and Indigenous governance, honour the protocols of my people, protect this knowledge for future generations, and fulfill the requirements of a dissertation. 


\subsection{The People: Nehinuw}

This dissertation focuses on my people, the Nehinuw. The Nehinuw are one of several groups of Cree people (Brightman, 1993; Okimasis, 2004; Paupanekis, 2008; Ratt, 2016; Wolvengrey, 2011), and they have a traditional territory spread across Northern Saskatchewan and Manitoba (K. Goulet, personal communication, October 25, 2012; Wolvengrey, 2011). I have focused on the Nehinuw that lived in and around my traditional territory, the Saskatchewan River Delta (Morrison, 2012). Based on this approach and after engagement with Nehinuw communities, I achieved consent to conduct research in two Nehinuw communities, Cumberland House, Saskatchewan and Opaskwayak Cree Nation, Manitoba. For a detailed map of the Saskatchewan River Delta, please see Appendix A.

While language texts employ dialect approach to the Cree language and identity, Nehinuw identity has evolved and is much more complex than the dialect approach suggests. Nehinuw identity, like other groups of Cree, is relational (Brightman, 1993: Wilson, 2008), which means that depending on the context, the Nehinuw may use a diverse set of terms to reference their identity including but not limited to "Nehinuw", "Ininew", "Ininiwuk" and "Waskahikanihk" (Goulet, 2013; Goulet \& Goulet, 2014, Wilson, 1989). Cree identity exists on a continuum between international to specific family territories. As Brightman explains, A Cree of Pukatawagan, Manitoba, might be defined in different contexts as Nihithaw 'Cree' (as opposed to other Indians or to Whites), as Asiniskaw-ithiniw 'Rock Cree' (as opposed to Swampy Cree or Plains Cree), as Pakitawakan-ithiniw “Pukatawagan person' (as opposed to other regional bands or reserve groups), and as Mwakwa-sakahikan-ithiniw 'Loon Lake person' or member of a group that hunts and traps at Loon Lake (as opposed to other Pukatawagan trapline groups). It is 
not always clear to which of these levels of social classification the names give in documentary sources refer. Neither, given the fluidity and mobility of Cree society, it is probable that groups or their names remained stable over time. (Brightman, 1993, p. 6)

Even though Brightman's work $(1993,2007)$ focuses specifically on the Rock Cree, a group of Northern Cree, his description accurately captures my understanding of Nehinuw identity. Therefore, there are several communities that speak the Nehinuw dialect and multiple ways to frame Nehinuw identity.

Contemporary political boundaries complicate Nehinuw identity even further. The Nehinuw community of Cumberland House has been separated into two communities, a municipality and reserve. This separation is the result of an intersection between multiple contemporary political boundaries such as treaty, the Indian Act, and the Canadian Constitution. While I like to think that the boundaries are only abstract, that we are a united people, boundaries have had a real impact on the Nehinuw identity of Cumberland House and the entire Nehinuw nation. For example, the Nehinuw have been separated by three provincial borders. Furthermore, Opaskwayak Cree Nation is the official name of the First Nation near The Pas, Manitoba. Opaskwayak is the only Nehinuw term in their official name. Thus, are individuals Nehinuw, Cree, or First Nation? The Nehinuw have never collectively sat down to create a consensus definition for Nehinuw identity. In other words, there is no universally applied identity term in the Nehinuw language and identity is much more dynamic and multicultural than the rigid assimilation model proposed in the Indian Act (Innes, 2013), which is currently in place and imposed by the Canadian Federal government (Palmater 2011a). In future research, I would like to explore the impact contemporary boundaries have had on Nehinuw identity. 
One Nehinuw community I worked with is Cumberland House. The Nehinuw people of Cumberland House have lived in the area since time immemorial (Goulet, 2013). Cumberland House is not the Nehinuw name for this area. There are three names for this area including Waskahikanihk (at the house) (Goulet, 2013), Kaminstigominuhigoskak (the bluff of spruce trees) (Goulet \& Goulet, 2014), and Menistick Menhague-a-skow (island of spruce land) (Rich, 1951). Waskahikanihk became a common term after the 1774 establishment of the Hudson Bay Trading post in Cumberland House (Goulet, 2013). Menistick Menhague-a-skow is a term the Hudson Bay Company recorded in 1775. Based on Nehinuw scholarship and historical records, most likely the Nehinuw people have always referenced the large bluff of spruce trees when describing the area that is now site of the Cumberland House municipality and adjacent Cumberland House Cree Nation reserve. Thus, depending on whom you talk with in the community, any one of these terms may be used to describe the area including both Nehinuw and English terms.

During the peak of the fur trade, Cumberland House was the most important trading post for the Hudson Bay Company (Goulet, 2013) as it is located at the convergence of two major waterways and in the center of North America's largest inland delta, ideal territory for beaver and other fur-bearing animals (Casey, 2013; Marchildon \& Robinson, 2015). From Cumberland House, it was easy to travel east-west and north-south to connect to numerous other resources in the area. In addition to being a significant junction, which the Nehinuw people had used for generations, it was easy to travel these rivers and between 1874-1932 steamboats were actively used to transport large quantities of tradable goods. Traders at the post were encouraged to intermarry with the local people (Goulet, 2013). The population in the area significantly decreased between 1780-1830 due to a small pox epidemic (Decker, 1988; Dorion \& Paquin, 
2003). The trading post in Cumberland House was in continual decline after 1850, as the fur trade economy was in decline and other trading posts rose to prominence, such as the post in The Pas, Manitoba (Dorion \& Paquin, 2003). In other words, the Cumberland House and surrounding area has been a site of Indigenous and settler interactions since at least 1774. Other settler interactions include the establishment of European missionaries including the first Anglican Church (1839) and first Catholic Church (1875). Indigenous people in the area signed Treaty 5 in 1875 (Goulet, 2013). However, some individuals signed Treaty 10 in 1906 (Dorion $\&$ Paquin, 2003). Treaty 5 established five reserves spread throughout the Saskatchewan River Delta including Cumberland House Cree Nation 20, Pine Bluff 20A and 20B, Muskeg River 20C, and Budd's Point 20D.

A significant influx of Métis moved into the area following the Red River insurrection in 1869-1870 (Bicentennial Committee of Cumberland House, 1974; Mailhot \& Sprague, 1985). Many of these Métis families moved to the area because they had been "discouraged by humiliations, bewildered by new government policies and uncertain about recognition of property rights" (Bicentennial Committee of Cumberland House, 1974, p.5) and the area was viewed as a land that could support their way of life. While the historical records do not discuss the social or political reactions of the Nehinuw people to this influx, the people in the region suffered through several epidemics (Mailhot \& Sprague, 1985) in some cases killing up to 50\% of the population (Bicentennial Committee of Cumberland House, 1974, p.5). My grandfather's genealogic research into his own Indian status found that several of his ancestors did at one time receive Treaty annuity payments with the Cumberland House Band (Indian and Northern Affairs Canada, personal communication, August 22, 1997). However, following the 1885 Northwest Métis resistance, the Canadian government sent agents to negotiate scrip in the area with anyone 
that had Indian and European ancestry (Mailhot \& Sprague 1985). I could not locate the exact numbers of Cumberland House Métis families that accepted scrip.

In reviewing my grandfather's genealogic research, I have started to wonder about the agency people had during the scrip process. For example, my great-grandfather negotiated scrip for his family. I know this because I have the scrips for him and his family. Each scrip has his signature. But it is my great-grandmother that was on the Cumberland House Band list. What agency did my great-grandmother have in the scrip negotiation process? Did she truly want to consent to this process or did this occur automatically once my great-grandfather accepted scrip? The outcome of accepting scrip has a profound impact on my family since they were then recognized by the Canadian state as not being Indian thereby not receiving treaty and status recognition such as attendance at residential school. Métis identity becomes prevalent in the area following the imposition of scrip (Dorion \& Paquin, 2003).

After 1885, the use of the steamboats in the area continued to diminish and impact the significance of the area's importance in the fur trade. Eventually, the trade significance of the area collapsed when the railway was completed through The Pas, Manitoba, in 1917. The Hudson's Bay Company transferred all trade functions from Cumberland House to The Pas at that time (Barris, 1977; Frances, 1982). Indigenous people in the area continue to maintain their way of life in the area throughout the World Wars and the depression. Thirty-five Cumberland House Veterans volunteered for WWI and 37 for WWII.

In 1962, the provincial government constructed the Squaw Rapids Hydro Dam. The dam severely alters water levels in the region, and a series of droughts debilitates the local trapping economy (Dorion \& Paquin, 2003; Goulet, 2013). While Indigenous people had lived in the area since time immemorial and the settlement of Cumberland House existed as a Hudson's Bay 
trading post since 1774, the municipality, Northern Village of Cumberland House was formally established by local leaders in 1973 (Dorion \& Paquin, 2003) creating two community centres. The Northern Village of Cumberland House is situated in the northern part of the island and is commonly referred to as "town". The Cumberland House Cree Nation is situated adjacent to the Northern Village on one of five reserves part of Cumberland House Cree Nation (Indigenous and Northern Affairs Canada, 2016a). For a visual overlay of the territory please see Appendix A. The division continues to this day, as now there are separate and duplicate services for the municipality and reserve. For example, there are two schools, one on reserve and the other in the village.

Cumberland House Cree Nation is the official name of the First Nation community. There were 1681 registered Indians as of September 2017 and 692 live off reserve (Indigenous and Northern Affairs Canada, 2017a). Cumberland House Cree Nation follows various components of Indian Act governance model. The various components of the Indian Act governance model are reviewed in section 2.3. The Indian Act (1985) was developed by the Canadian government, and the Canadian government has passed 92 additional acts and 26 regulations that provide further clarification on the implementation of the Indian Act (Indigenous and Northern Affairs Canada, 2017b). For example, Cumberland House Cree Nations uses a Custom Electoral System (Cumberland House Cree Nation, 2015; Indigenous and Northern Affairs Canada, 2017c), which is one of four electoral systems recognized by the Canadian government (Indigenous and Northern Affairs, 2016a). Under this system one Chief and four Councilors serve three-year terms (Indigenous and Northern Affairs Canada, 2016a). The Cumberland House Cree Nation also uses the Indian Band Council Procedure Regulation (2009), which dictates the procedures of band council meetings. During additional discussions with 
community leadership, Councilors are assigned specific work portfolios and band council decisions are made by vote and the Chief has the deciding vote. Furthermore, there are frequent community forums to discuss a variety of decisions and the Cree Nation has created an Elder's council, which participates in band council meetings. Nehinuw and English are the working languages. I have not formally worked for the Cumberland House Cree Nation, but in my interactions with the Chief and Council, the Nehinuw language and governance theories are used within the contemporary Indian Act governance system.

Northern Village of Cumberland House is the official name of the local provincial community. As of 2016, there were 671 people living in the Northern Village of Cumberland House (Statistics Canada, 2016). The Municipalities and Northern Municipalities Acts defines the powers and governance processes of the Northern Village of Cumberland House (Government of Saskatchewan, 2015). Cumberland House follows the provincial electoral system outlined in these Acts, which sees one Mayor and four Aldermen democratically elected to represent the community. In addition, one administrator and one clerk staff the Northern Village (Government of Saskatchewan, 2016). One caveat in Cumberland House's decisionmaking process is that Aldermen are assigned specific portfolios instead of using committees, as recommended in the Northern Municipalities Act. However, decision-making is still decided by vote and the Mayor can vote on all motions (A. Bishoff, personal communication, December 7, 2016). English is the working language since not all members are Nehinuw, but Nehinuw is frequently spoken by the Mayor and Council. This dissertation was completed in partnership with both the Northern Village and Cree Nation.

The second Nehinuw community I focused on in this dissertation is The Opaskwayak Cree Nation, previously known as The Pas Indian Band. Opaskwayak is a Nehinuw term that 
means "wooded narrows" (Wilson, 1989). The Opaskwayak Cree Nation also has a long history of contact with Europeans. The French first build a fort in 1749 in the area named Fort Paskoyak (Thistle, 1986). While European settlers described the area as an "important seasonally occupied Indian village" (Thistle, 1986, p.20), Nehinuw origin stories place people within the region since time immemorial.

In total, there are four names of the modern area of Opaskwayak Cree Nation, Opaskwayak, The Pas, Fort Paskoyak, and Basquiau. During the 1760's, the Nehinuw and settlers increasingly interacted with each other, specifically through the competition of the fur trade in the region (Thistle, 1986). Increased fur trade in the region led to hostilities between the Nehinuw and settlers. In 1775, a headman of Cree families denied entry of traders into the area (Thistle, 1986). The Cree continue to maintain their independence in the area until a series of epidemics and starvation between 1821-1840 decimated the Cree population (Barris, 1977; Thistle, 1986). The first Anglican church was established in the area in 1840 (Ray, 1974). The Opaskwayak Cree Nation signed Treaty 5 in 1876 . However, Opaskwayak leadership protested the terms of Treaty because previous treaties had provided better terms. The Canadian government argued that Treaty 5 provided fair compensation since Northern lands had less agricultural value (Coates \& Morrison, 1986). In 1906, the Opaskwayak Cree Nation was forced to surrender a portion of their land on the south bank of the Saskatchewan River as part of the bands treaty obligations. This land would become both the site of the new railroad (Coates \& Morrison, 1986) and the town site of The Pas municipality, which incorporated in 1912 (Opaskwayak Cree Nation, 2016b). The region continues to be defined by this 1912 separation and currently the Opaskwayak Cree Nation is predominantly on the north shore of the Saskatchewan River, although the Opaskwayak Cree Nation has several reserves in the 
surrounding area, and the municipality of The Pas is located on the south shore (Wilson, 1989). Throughout the early part of the 1900s, resource development in the area shifted away from the fur trade to the lumber industry, which laid the foundation for the industry to this day (Barris, 1977).

The Opaskwayak Cree Nation underwent a revitalization once some of the restrictive measures of the Indian Act were dropped in the 50s and 60s including cultural restrictions and right to legal counsel. Following these developments, the Opaskwayak Cree Nation "pursued greater autonomy in the management of Band Affairs" (Opaskwayak Cree Nation, 2016b, para.4) including administration and program delivery, governance authority, and economic development. The Opaskwayak Cree Nation has developed many businesses and provides significant support for the community including Paskwayak Business Development Corporation, Otineka Shopping Mall, and Opaskwayak Cree Nation Blizzard (Opaskwayak Cree Nation, 2016b). Despite diversity of the Opaskwayak Cree Nation's business portfolio, the region is in a severe economic crisis as many local businesses have closed and major industries such as the local pulp mill and retail stories have closed or relocated (Kavanagh, 2016).

As of 2017, there were 3294 registered Indians living on reserve. In total, Opaskwaywak Cree Nation has 6098 registered Indians (Indigenous and Northern Affairs Canada, 2017d). The community uses a Custom Electoral System titled Opaskwayak Cree Nation Election Code in which one Chief, one Vice Chief, and seven Councillors are elected to serve three-year terms (Opaskwayak Cree Nation, 2016a, p.5). While there are specific regulations for the format of band council meetings, see the Indian Band Council Procedure Regulation (2009), the decisionmaking process of the Opaskwayak Cree Nation is dynamic process that includes elected representatives and Elders. This dynamic process represents just one way a First Nation 
community has found ways to subvert the processes of the Indian Act, such as using Nehinuw terms for Chief and Councillors, Onekanew and Oneschewaka, and a greater role for the Assembly of Elders. Both the Nehinuw and English language were used during the meeting that I attended.

Despite calling both these communities my home, I did not truly understand the impact Canadian law and policy was having on these communities until I started to study Indigenous governance. The Indigenous governance that I wanted to learn about was Indigenous governance in Indigenous terms. Using this lens, comparing the Indian Act structures of these two communities would not meet that goal. The Indian Act and all components of the Canadian Indigenous governance framework would tell us something about the contemporary reality of Indigenous governance but not what Indigenous governance is in Indigenous terms.

\subsection{The Problem: What is Indigenous Governance?}

I never had a clear idea what I wanted to do with my life until I began to learn about Indigenous governance. Being Indigenous is a political experience. The Canadian state creates boundaries within our nations, by defining who is and is not an Indian, and between our nations, the Saskatchewan/Manitoba boundary intersects Nehinuw territory. I gained a practical understanding of the challenges and opportunities of Indigenous governance when I worked for the Saskatchewan provincial government and at the Federation of Saskatchewan Indian Nations, now known as the Federation of Sovereign Indigenous Nations. Formally, I started to learn about Indigenous governance in my undergraduate political science degree at Simon Fraser University. However, Indigenous governance was never the central focus of my formal education; it was either a special topic or not covered at all throughout my career in political science, public administration, public policy and policy studies. At Ryerson University during 
my Ph.D. course work, there was no Ph.D. class on Indigenous governance. I had to enroll in a master's class and design a directed readings class to learn more about Indigenous governance. I realized that much of what I had learned about Indigenous governance was not Indigenous. The field of Indigenous governance is predominately studied within the framework of Canadian governance. For example, understanding the Indian Act, Section 35 of the Constitution, and Supreme Court decisions are components of Canadian Indigenous governance, so they are not Indigenous instruments of governance. In other words, nearly my entire education on Indigenous governance explored Canadian Indigenous governance. Despite all I had learned, I had never asked what is Indigenous governance in Indigenous terms? I used my preparation for this dissertation to help me gain a deeper understanding of Indigenous governance in Indigenous terms and the literature told me a story that I had experienced throughout my life.

Indigenous people have complex and ancient political theories and practices (Alfred, 1995; Battiste, 1997; Borrows, 2010; Deloria Jr., 1997; Ladner, 2001b; Pratt, Bone, \& The Treaty and Dakota Elders of Manitoba, 2014; Simpson, 2011). These theories and practices have not solely been implemented within Indigenous society; they have influenced Canadian and American political institutions (Jacobs, 1991; Johansen, 2009; Saul, 2008; Wilkins \& Stark, 2011). For example, Canadian political authority is derived from its treaty relationship with Indigenous peoples (Borrows, 1997; Henderson, 1994; Venne, 1997), yet official government policy, law, and academic research has tried to assimilate, eliminate, suppress, and deny the theories and practices of Indigenous governance (Ladner, 2001b; Miller, 2004; Palmater, 2011b). The result is that contemporary Indigenous governance has been largely structured according to Euro-Canadian knowledge and values (Ladner, 2014). Thus, to answer a question like, what is 
Indigenous governance, requires a careful examination of the literature and an explicit focus on the knowledge of Indigenous people.

As I started to explore the literature, I realized that much of the literature focuses on the Canadian Indigenous governance framework. Belanger and Newhouse (2004) recognize that the field of Indigenous governance reemerged in response to Prime Minister Pierre Trudeau's attempted termination of Indigenous rights in 1969. In Belanger's (2008) foundational Indigenous governance text, the book frames Indigenous governance in relation to the Canadian state. Of course, the authors recognize the unique and ancient nature of Indigenous governance (Belanger, 2008; Belanger \& Newhouse, 2008; Chartrand, 2008). Henderson (2008a) discusses the Indigenous political theory of Treaty Federalism, but Treaty Federalism is framed in English terms and does not identify a specific nation's body of knowledge. Henderson (2008) provides the best example of discussing the relevance of Indigenous governance in Indigenous terms when she critiques the Nunavut Land Claim Agreements inability to incorporate Inuit Quajimajatuquangit (Inuit traditional knowledge); however, this chapter critiques the Nunavut land claim and does not specifically explore Inuit governance. While this book only represents a small sample of the Indigenous governance literature, little research has explored Indigenous governance in Indigenous terms. The research and activism has focused on the how and why of Indigenous governance (Belanger \& Newhouse, 2004; von der Porten, 2012). There is a growing body of research that argues for the resurgence and revitalization of Indigenous governance in Canada (Alfred, 2005; Borrows, 2010; Corntassel, 2012b; Coulthard, 2014; Ladner, 2001b; McAdam, 2015; Palmater, 2011a; Simpson, 2011; Wastesicoot; 2015), and this dissertation aims to expand our theoretical knowledge of Indigenous governance by addressing the question of what is Indigenous governance through the knowledge of the Nehinuw. Thus, the main research 
question of this dissertation is: what does Nehinuw knowledge teach us about Nehinuw governance?

\subsection{The Focus: Governance}

I have chosen governance as the central research term for two reasons. First, governance has a broad definition that encompasses elements of politics, law, decision-making, and administration (Beatty, 2006).

Governance refers...to all processes of governing, whether undertaken by a government, market, or network, whether over a family, tribe, formal or informal organization, or territory, and whether through laws, norms, power or language. Governance differs from government in that it focuses less on the state and its institutions and more on social practices and activities. (Bevir, 2012, 1. 391)

Framing this study around a broad concept like governance is critical because there are so many Indigenous perspectives on governance and research is only just beginning to explore, "Indigenous governance [in] its own terms" (Ladner, 2001b, p. 11). Thus, a broad term will allow my participants to share their understanding of governance. If I were to focus instead on another concept, such as politics, this concept could potentially limit discussions on Nehinuw governance. For example, an individual that did not have specific political experience might feel that they could not contribute. Other concepts like political science, which has traditionally focused on the state (Peters, Pierre, \& Stoker, 2010), and public administration, which has traditionally focused on the bureaucracy (Inwood, 2012), could also limit the discussions I want to have on Nehinuw governance. While the rigid separation of politics and administration has been challenged (Frederickson \& Smith, 2003; Overeem, 2008; Svara, 2008; Waldo, 1948) and the centrality of the state has been questioned (Isett, Mergel, LeRoux, Mischen \& Rethemeyer, 
2011; Kahler, 2009; Stoker, 1998; Wachhaus, 2009), using a broad term will allow for an openended exploration of governance in Indigenous terms.

Second, governance is a frequently used concept in the field. For example, Saskatchewan Indigenous institutions have used and use this term (Federation of Saskatchewan Indian Nations, 2015; Opekokew, 1980) and the term has become a rallying point since the 1969 Statement of the Government on Indian Policy (Belanger \& Newhouse, 2004; Shaw, 2013). The Indigenous Governance program at the University of Victoria defines Indigenous governance as "traditional structures and ways of governance and encompassing the values, perspectives, concepts, and principles of Indigenous political cultures" (University of Victoria, 2013, para. 1). Additionally, the Canadian government supports Research Chairs in Indigenous Governance (Government of Canada, 2013) and other institutions have chairs and programs in Indigenous Governance. For example, Ryerson has the Centre for Indigenous Governance and a Chair in Indigenous Governance (Ryerson University, 2017).

\subsection{The Rationale: Protection for the Future}

There are several reasons why I have framed this dissertation around the Nehinuw and Nehinuw governance. Nehinuw is an Indigenous term and it is used in the field and academic literature (Goulet \& Goulet, 2014). I agree that decolonization requires a commitment to exploring Indigenous knowledge in its own terms (Alfred \& Corntassel, 2005; Ladner, 2001b; Simpson, 2004). Furthermore, using an English equivalent would be general and inaccurate. While I agree that the Cree people have some shared philosophical beliefs (Cardinal \& Hildebrandt, 2000), the Cree have an extremely diverse and complex identity (Brightman, 1993; K. Goulet, personal communication, October 25, 2012). Using the appropriate Indigenous term empowers Indigenous citizenship theories and practices and ensures that you are discussing a 
specific group of people and concepts. Thus, I mainly use the term Nehinuw to discuss the people that are the focus of this dissertation.

I also use several English terms and concepts throughout this dissertation, such as Indigenous, First Nation, Cree, Swampy Cree and Aboriginal. In the broader context, I primarily use Indigenous because "Indigenous" captures the spirit of resurgence and empowerment that inspires this dissertation. "The communities, clans, nations and tribes we call Indigenous peoples are just that: Indigenous to the lands they inhabit" (Alfred \& Corntassel, 2005, p. 597). There are many Indigenous peoples in Canada, First Nations, Inuit, and Métis. There are situations that call for the use of a specific English term and concept, where appropriate I will use these specific concepts. For example, there is a part of this dissertation that analyzes the impact of section 35 of the Constitution. This section of the constitution uses the term "Aboriginal". In the context of that assessment I will use Aboriginal. Furthermore, when discussing the literature, I will use the specific terms identified by the author. For example, Battiste first used the term Míkmaw (1997) and in future publications used the term Mi'kmaw (2016).

In terms of Nehinuw governance, there are a several gaps that are addressed by this dissertation. First, research on Indigenous governance in Indigenous terms is limited and underrepresented in the literature (Abele, 2007a; Fondahl \& Irlbacher-Fox, 2009; Ladner, 2001b; Maaka \& Fleras, 2009; Timpson, 2006), and no study has explicitly explored Nehinuw governance. Despite the long history of contact between the Nehinuw and European settlers (Barris, 1977; Francis, 1982; Ray, 1974; Rich, 1951), knowledge of Nehinuw governance is still alive and is collectively held by the Nehinuw. Elders are the experts. Furthermore, many people in the area are fluent in Nehinuw culture and language. Language is a key source of knowledge 
and self-determination (Viatori \& Ushigua 2007). Exploring Nehinuw knowledge on Nehinuw governance will allow us to learn about a unique approach to Indigenous governance.

Furthermore, in the face of this long history of colonization in the area, exploring Nehinuw knowledge on Nehinuw governance has considerable potential to revitalize Nehinuw forms of governance and support the resurgence of the Nehinuw people.

Second, critical research on Indigenous governance that explores governance in Indigenous terms is a new and developing field of research. Indigenous scholars (Borrows, 2002; Ladner, 2001b) have continually advocated for more research on Indigenous political traditions. The Social Sciences and Humanities Research Council (SSHRC) identifies a "very wide range of Aboriginal research themes [including but not limited to] Aboriginal governance" (McNaughton \& Rock, 2004, p. 4). Academics have also called for the development of alternative approaches on governance (Jones \& McBeth, 2010; Maaka \& Fleras, 2009; Orsini \& Smith, 2007; Roe, 1994; Sabatier, 2007; Schlager \& Weible, 2013), Indigenous theories of governance (Riley, 2007), and the revitalization and decolonization of Indigenous knowledge (Alfred, 2005; Simpson, 2008b; Smith, 2012). In addition to addressing these gaps, this dissertation was designed from a Nehinuw theoretical perspective, as detailed in Chapter 3. This approach makes considerable contributions to the broader field of Indigenous knowledge by expanding perspectives on Indigenous research.

Third, this dissertation will help stakeholders develop a deeper understanding of Nehinuw governance. Of course, to have this impact I will ensure that my dissertation is widely published beyond the dissertation. The stakeholders that will benefit the most from this knowledge are the federal and provincial government, business organizations, and the non-profit sector. I believe that a lack of understanding the diversity and complexity of Indigenous governance on the part 
of non-Indigenous scholars, policy makers, and stakeholders has been one of the central causes for the continued colonization of Indigenous people. If these stakeholders developed a deeper understanding of Nehinuw governance, this will lead to the creation of better and more responsive policy, laws, and legislation. I make this claim because the Canadian Indigenous governance framework is paternalistic (Coulthard, 2014; Palmater, 2011a, 2011b, 2015) and genocidal (Ladner, 2014; Neu \& Therrien, 2003; Truth and Reconciliation Commission of Canada, 2015) because it has not recognized Indigenous governance (Belanger \& Newhouse, 2008; Henderson, 2008). So, meaningful understanding will only occur when Canadians recognize Indigneous constitutional orders (Ladner, 2005). If that theoretical argument is not convincing, policies that integrate Indigenous knowledge have been shown to be more successful (Cooke \& McWhirter, 2011; Cornell \& Kalt, 1998; Cornell \& Taylor, 2000; Irlbacher-Fox, 2009; Jorgensen \& Taylor, 2000; Mitchell \& Bruhn, 2009; Niezen, 1993; Regan, 2010; Timpson, 2006).

Finally, and most importantly, Indigenous knowledge around the world is either threatened, near extinction, or extinct (Makokis, 2001; Settee, 2007; Stonechild, 2016). Nehinuw knowledge is no different. The key outcome of this dissertation is the Glossary of Nehinuw Governance Theories and Practices. This glossary represents the concepts that were shared by Nehinuw Elders and experts. I feel that this glossary protects the knowledge explored in this dissertation for future Nehinuw generations, and I hope that one day I will be recognized by my community as a knowledge keeper. For the moment, I know that I still have much to learn. 


\subsection{The Approach: Nehinuw Research Paradigm}

I am Nehinuw. It feels great to say this, but it also feels great to put the knowledge of my people into action and work towards the protection of this knowledge. Being Nehinuw has shaped the topic and theoretical framework that I have used for this dissertation. I have consciously made the effort to research from a Nehinuw research paradigm. While the protocols and procedures of a Nehinuw research paradigm are not defined in a central document, this paradigm has existed and been practiced since time immemorial. Because there is no central Nehinuw research paradigm guide, the research paradigm I use in this dissertation is based on my interpretation, the work of Keith Goulet, and Indigenous research literature. Based on these sources, I have identified four key principles of a Nehinuw research paradigm including support and protection of Indigenous knowledge; collection of knowledge using an Indigenous language and methods; interpretation of knowledge based on an Indigenous worldview; and partnership and collaboration with specific Indigenous communities. In addition to these principles, I use several Nehinuw concepts that Goulet identifies in his work (Goulet \& Goulet, 2014) including Weechihitowin, Weetumatowin, and Nistotên. Weechihitowin (helping or supporting each other) is a teaching philosophy that I use as a methodology. I elaborate on the Weechihitowin methodology in Chapter 3. Weetumatowin (sharing of information) is the key narrative framework that I use to explore the central research question. I elaborate in this method in section 3.2. Nistotên (to understand) is the Nehinuw verb to understand and I use this concept as the basis for a unique method of analysis. I elaborate on this in section 3.3. From this moment forward, I will use these Nehinuw concepts to refer to the various components of the research paradigm I used in this dissertation. I expand in detail on these concepts in Chapter 3. 
I felt it was necessary to go beyond the Indigenous methodology literature and focus explicitly on the Nehinuw because there is little research that focuses on the Nehinuw. Furthermore, I believe there are considerable differences amongst the various groups of Cree people that warrant further research on their specific knowledge. For example, the literature recognizes that there are at least three groups of Cree people in Saskatchewan (Okimasis, 2004; Ratt, 2016), yet there are considerable intellectual differences between these groups. When I was in Regina, I met Nêhiyawak (Plains Cree people) from Treaty 4 territory and they would tell me about their history as horse people. Nêhiyawak culture is considerably different from my Nehinuw and the other groups of Cree peoples. These differences are also apparent in the literature. Kovach (2009), who writes from a Nêhiyaw (Plains Cree) perspective, comprehensively discusses Indigenous methodology. She discusses the theoretical value of the Indigenous research. While her work is critical to the field of Indigenous methodology, I felt like I needed to expand on her work because I am unsure if all aspects of methodology that she discusses apply to the Nehinuw. Her work is based on the Nêhiyaw worldview. The Nehinuw and the Nêhiyaw are both groups of Cree (K. Goulet, personal communication, March, 16, 2013; Okimasis, 2004; Ratt, 2016), yet these groups have linguistic and cultural differences (Goulet \& Goulet, 2014, Okimasis, 2004). I feel there is enough of a difference that more effort should be put into working with Indigenous communities to use appropriate methodologies. We should not assume that there is a pan-Indigenous methodology. There should be an effort on the part of the researcher to ask Elders for guidance on the methods of each Indigenous group. For example, Kovach (2009) discusses the role of sharing circles in the Indigenous methodology. However, based on my experiences and input from other researchers in the area, I wondered if the Nehinuw had used sharing circle as a research method within their worldview. Therefore, I collaborated 
with the communities that are part of this dissertation to ascertain which method was preferred by the communities. Based on input from the communities, interviews were the preferred method of research.

\subsection{Research Questions}

This dissertation explored Nehinuw governance through the Nehinuw narrative framework of Weetumatowin. As has been shown from previous research, Indigenous governance is largely structured by Euro-Canadian philosophies and institutions (Abele, 2007b; Alfred, 2009a; Gunn, 2007; Ladner, 2001b; Monture-Angus, 1999; Palmater, 2011a), little research has explored Indigenous governance in Indigenous terms, and none has explored Nehinuw governance. In recognition of these gaps, the main research question of this dissertation is, what does Nehinuw knowledge teach us about Nehinuw governance? To answer the main research question of this dissertation, I have also identified several sub-questions as a guide around the central research question.

1) What is Nehinuw governance?

2) How does Nehinuw governance incorporate Nehinuw knowledge?

3) Who were and are the key actors of the Nehinuw governance and has that changed?

4) What is the jurisdiction of Nehinuw governance and has that changed?

5) How does the contemporary governance process utilize traditional values and principles of governance?

6) How can Canadian governance become more inclusive of Nehinuw governance?

7) How do other Indigenous organizations incorporate Indigenous knowledge?

8) What aspects of Nehinuw governance should key stakeholders be aware of when working with Nehinuw communities? 


\subsection{Thesis Organization}

This dissertation is organized into six chapters. In this first chapter, I have identified the inspirations and goals of this dissertation. This chapter includes my self-location, a brief overview of the context, and a brief description of the theoretical framework used to explore Nehinuw governance in Nehinuw terms. I use chapter two to kiskinaumasowin (teach myself) about Indigenous governance. I have used this review to explore the field of Indigenous governance. I begin discussing research that explores Indigenous governance in Indigenous terms with a specific emphasis on Cree governance literature. I then proceed to discuss the field of Indigenous governance in terms of two broad themes colonization and decolonization. I use this chapter to show the lack of research that explores Indigenous governance in Indigenous terms. This dissertation aims to address this gap. Chapter three describes the theoretical approach and describes in detail the methodology and procedures of this dissertation. Chapter four presents the findings of this study. These findings are organized according to themes that emerged during Weetumatowin. I support each theme with several stories and reflections. The fifth chapter is my attempt to analyze Weetumatowin using the framework of Nistotên. Nistotên is the Nehinuw term for understanding. In this chapter, I attempt to show that ninistotên ( $I$ understand) Nehinuw governance within the Nehinuw worldview. The final chapter discusses the implications, lessons, and recommendations for further research.

\subsection{Language}

The Nehinuw language is prevalent throughout this dissertation. This dissertation is structured using the American Psychological Association style. The guide implies that writers should use italics for foreign phrases not common in English (American Psychological Association, 2010). For example, one sentence from this dissertation is "I want to prove to you 
that ninistotên (I understand) Nehinuw governance". According to the American Psychological Association manual, this sentence should be written "I want to prove to you that ninistotên Nehinuw governance". Like Jobin (2014), I have decided to make this change because I believe that not using italics empowers the Nehinuw language to stand on equal terms with English. There are cases where I will be discussing a specific concept within a paragraph and I will not continually include the translation each time I use the concept. Furthermore, there are cases where I describe the Nehinuw term in English and brackets are not required. The one exception to this rule is the term Nehinuw. I provide a detailed definition of this term in section 1.2 and I do not provide any additional translation for this term.

In addition to resisting the use of italics around Nehinuw terms, I have also used several different spelling formats in this dissertation. As mentioned earlier, I am not fluent in the Nehinuw language and I only have a working knowledge of the language. The spelling of Nehinuw and other Cree terms are based specific spellings used in text, identified in Cree language texts, identified by the research participants, and my understanding of the Cree language, which I reviewed with an interpreter. Keith Goulet and other sources use a phonetic spelling style. This spelling style is more common in older texts. For example, the historic Hudson's Bay Journals use the phonetic spelling style (Rich, 1951). Modern sources utilize standard roman orthography. Standard roman orthography is "a phonemically-based writing system now in increasingly common use throughout much of western Cree territory and advocated by First Nations University and the Saskatchewan Cree Language Retention Committee among other education authorities" (Wolvengrey, 2011, p. 9). As noted here, the issue with standard roman orthography is that this technique is still developing (Jobin 2014). 
Thus, even in sources that use standard roman orthography there are slight differences in spelling.

Finally, the verb Nistotên (to understand) is central to the method of analysis undertaken in this dissertation. Verbs are central to the Nehinuw language and there are several forms of verbs in the language (Ratt, 2016; Wolvengrey, 2011). The key difference in the Nehinuw language, and other languages in the same family, surrounds the concept of animacy.

The most important grammatical distinction to be found in Cree, and throughout the Algonquian family of languages, is the 'gender' or noun classification distinction between 'animate' and 'inanimate'. Much has been written concerning the elusive semantic basis for this distinction (cf. Goddard 2002 for a summary of selected "descriptions of Algonquian gender, 1634-2000"), with a fairly common theme being the anthropologically-based attribution of spiritual power to the animate at the apparent expense of the inanimate (e.g. Darnell and Vanek 1976)... Regardless of the ultimate basis of the animacy distinction, the importance of this difference to the grammar of the Algonquian languages and certainly to Cree is beyond doubt. In fact, it could (and will) be argued that the animacy distinction has become even more important to Cree grammatical distinctions than throughout the remainder of the Algonquian family. (Wolvengrey, 2011, p.12)

The reason I mention the concept of animacy is that animacy impacts most Nehinuw verbs and Nistotên is one of those verbs. I have chosen this verb form because this form is what Cree linguistic scholars would classify as an intransitive animate verb. These types of verbs "are of a common occurrence which have animate actors and take no objects" (Ratt, 2016, p.88). The translation of this form of the verb Nistotên is "to understand", but as noted above this specific 
verb form takes no object. In other words, when I say Ninistotên the translation is "I understand", but there is no object to understand. Focusing on the intransitive animate verb form of Nistotên may be problematic because this dissertation attempts to understand and explore Nehinuw governance. Since I am attempting to understand an object, in this case Nehinuw governance, one of the other verb forms, depending on animacy/inanimacy context, may be more accurate. However, I use the intransitive animate verb form in this dissertation because this form translates broadly into Nistotên "to understand" and Ninistotên "I understand". This intransitive animate verb form and broader translation may be more appropriate since I did not discuss the animacy of Nehinuw governance or the other Nehinuw concepts in this dissertation. 


\section{Chapter 2: Kiskinaumasowin (Teaching yourself)}

\subsection{Literature Review Approach}

Kiskinaumasowin refers to "the act of teaching oneself" (Goulet \& Goulet, 2014, p. 65).

I see the literature review and this chapter as a process in which I teach myself about Indigenous governance. I want to learn about Indigenous governance because this dissertation aims to contribute to the field of Indigenous governance by exploring Nehinuw governance in Nehinuw

terms. To obtain literature on this topic I used a three-pronged search string. The first term used in my search string was "Nehinuw". I combined this term with one the following governance terminologies, "governance”, “politics”, “self-government”, "law”, “policy”, "public administration", and "political theory". These two terms were encased in quotation marks. The search string also included the geographic location of Canada. For example, one final search string was "Nehinuw governance" and Canada. Finally, I decided not to place a time restriction on my searches to access the widest possible amount of literature on Nehinuw governance.

I began by entering these search strings into the Ryerson University library and archive (RULA) research website. RULA has access to over 300 online databases including ProQuest Research Library, America: History \& Life, Sociological Abstracts, Social Services Abstracts, North American Indian Thought and Culture, CPI.Q Canadian Periodicals Index, CBCA Complete, ProQuest - Social Sciences, Academic Search Premier, Scopus, IngentaConnect, Canadian Research Index, Dissertations \& Theses, and Worldwide Political Science Abstracts. RULA also has access to the Informit Indigenous Collection which has access to "over 15,700 full text records from 111 resources" (Ryerson University Library and Archives, 2016, para. 4). Following these searches, I reviewed material from specific journals that publish research on Indigenous governance including Canadian Journal of Native Studies, Native Studies Review, 
First Peoples Child \& Family Review, Wicazo Sa Review: A Journal of Native American Studies, Aboriginal Policy Studies, Indigenous Affairs, Indigenous Law Journal, and Decolonization: Indigeneity, Education \& Society. Additionally, I searched grey literature from government and non-governmental organizations including Government of Canada, Assembly of First Nations, National Centre for First Nations Governance, and the United Nations. I also reviewed sources that were shared with me during the research process. I reviewed literature from diverse disciplines including Native studies, education, health, law, politics, public administration, and Indigenous methodology. Finally, source reference lists were reviewed to obtain additional material that may have been published outside of these venues. Since no literature was discovered that focused explicitly on Nehinuw governance in Canada, I expanded my search strings to include "Cree", "Native", "Native American", "American Indian" "First Nations", "Tribal", "Metis", "Indigenous", and "Aboriginal" as the primary search term. I excluded some terms that are used in the field that would refer to people that have not traditionally occupied space within the Saskatchewan River Delta including Inuit, Pacific Islander, Alaskan Native, Hawaiian, Maori, Sami, and Australian. Based on the broader search results, I found multiple sources on this topic that have helped me kiskinaumasowin (teach myself) about Indigenous governance.

Because there are several complex and interconnected layers to this literature, I use a chronological thematic approach to assess this literature. Unlike Belanger (2005), who feels that "maintaining a balanced academic approach is an important objective" (p. 11) to assess the legacy of Canadian Indigenous policy, I feel that the narrative of this relationship is one of colonization and to structure it any other way ignores the reality of historical and current policy objectives. Therefore, I have structured this chapter according to this narrative. I begin by 
reviewing literature that explores Indigenous governance in Indigenous terms. This literature is foundational to understand Indigenous governance. Next, I will chronologically discuss the impact colonization has had on Indigenous governance. I begin by discussing the foundations of settler Indigenous policy and then proceed to analyze the central laws and policies of the Canadian Indigenous governance framework. Finally, since I believe that the decolonization of Indigenous governance is best served by the resurgence of Indigenous governance theories and practices, the last section of this chapter will assess the resurgence of Indigenous governance. I use this structure to kiskinaumasowin (teach myself) about Indigenous governance and to show there is a need for research that explores Indigenous governance in Indigenous terms, a gap addressed by this dissertation.

\subsection{Indigenous Governance in Indigenous Terms}

The theory of Indigenous governance, like other forms of Indigenous knowledge (Deloria Jr., 1997), has been ignored in academia (Irlbacher-Fox, 2009; Ladner, 2001b), and the practices

of Indigenous governance have been erased (Ladner, 2014). Yet, Indigenous governance theories and practices have had an impact in Canada and the United States (Borrows, 2010; Doxtater, 2011; Mann, 2006, 2011; Saul, 2008; Tully, 1995; Williams, 1993). For example, Jacobs (1991) argues that the Iroquois Great Law of Peace influenced the development and structure of the United States Constitution. Indigenous people, nations, and academics are now exploring the decolonization of Indigenous governance. While it may not be possible, after 400 years of settler-colonialism, to access “pure” knowledge of Indigenous governance, knowledge of Indigenous governance is alive and contained in the oral knowledge of Indigenous peoples (McAdam, 2015; Porter, 2005; Wheeler, 2010). The central issue that this dissertation aims to address is, what is Indigenous governance in Indigenous terms, specifically through the lens of 
the Nehinuw people. I want to ask this question because the field of Indigenous governance has predominately focused on the Canadian Indigenous governance framework. The Canadian Indigenous governance framework is the governance of Indigenous people according to EuroCanadian theory and practice, which includes laws and policies such as the Indian Act, selfgovernment agreements, and the Constitution. For example, the Indian Act replaced First Nations governance theories and practices with a specific set of Euro-Canadian governance rules and procedures (Monture-Angus, 1999). While understanding the Canadian Indigenous governance framework is critical to contemporary practices of Indigenous governance and the decolonization of Indigenous governance, Canadian Indigenous governance is not Indigenous governance. I begin my quest to kiskinaumasowin (teach myself) and show the need for this dissertation by exploring Indigenous governance in Indigenous terms.

Indigenous nations have always had governance. Pre-contact Indigenous governance was a mixture of intratribal and intertribal governance theories and practices (Belanger, 2014; Wastesicoot, 2015). There are two sources, oral and written, for information on pre-contact Indigenous governance theories and practices. Much, if not all, of the written information about Indigenous people at contact is based on European historical records (Ray, 1974; Russell, 1991) and is extremely descriptive (Smith, 1981). On the other hand, Indigenous oral knowledge, while told in a contemporary setting, is a living body of knowledge and there are specific and sacred protocols for passing down that knowledge (Wheeler, 2010). Thus, I want to begin this exploration of Indigenous governance focusing on Indigenous authors that discuss Indigenous knowledge from an Indigenous lens. Furthermore, since this dissertation focused on the Nehinuw, one of many groups of Cree people in Canada, I have focused specifically on Nehinuw 
and Cree literature. I will then discuss Indigenous governance literature from the lens of other Indigenous nations across Canada.

While there are many reports and articles that discuss the Cree, I will begin my journey to teach myself about Cree governance by discussing the first comprehensive ethnographic and historical study of the Plains Cree (Mandelbaum, 1979). Mandelbaum, a non-Indigenous American anthropologist, discussed Plains Cree life primarily based fieldwork completed between 1934-35. Even though Mandelbaum is non-Indigenous, I am including his work in this review because Mandelbaum's work was based on the oral knowledge of several key Plains Cree informants, principally Kamiokisihkwew (Fine Day). As an ethnography and historical study of the Plains Cree, Mandelbaum (1979) provides a comprehensive view into the life of the Plains Cree. For example, he provides extensive descriptions of Plains Cree games such as the stick dropping game. Of relevance for this review is the chapter Social Life. In this chapter, he describes chieftainship, social division, and justice based on long verbatim stories from his informants and using Plains Cree concepts. In terms of chieftainship, there is no mention of the Plains Cree word for Chief, but he does provide some details on the expectations of a Chief, namely a Chief must be brave, accomplished, and knowledgeable. Furthermore, the chieftainship was often hereditary. Mandelbaum also provides some description on several groups within the community. Ocakitostamakew were individuals that carried news and orders around the community. Otepwestamakew were additional criers that had a higher level of prestige than Ocakitostamakew. Otepwestamakew were often older, and directly connected to the Chief. Underneath the Chief, there were Okihtcitawak (Warriors) then Kihtochinikiwak (Worthy Young Men). Eventually, older warriors became Oskapewisak (Servers) and they would help the Chief, warriors and worthy young men. Finally, in terms of justice, decisions within the 
community were made based on input from the entire community. Elders and Chiefs had considerable influence in the outcome of the justice system and decisions were finalized with a pipe ceremony.

Mandelbaum's (1979) work, originally completed between 1934-1940, is considered a seminal piece of anthropological research and the first comprehensive view of the Plains Cree. In terms of governance, we get a sense that Plains Cree leadership was dynamic and complex. While it appears that Chiefs had considerable influence, we also see that there were various groups that influenced decision making such as Okihtcitawak (Warriors) or Kihtochinikiwak (Worthy Young Men). However, there are several issues with Mandelbaum's work. First, his work is descriptive. Once he identifies specific concepts there is no further discussion on that specific concept. For example, he describes the qualities of a Chief supported with one informant story before continuing to the next topic. There is no analysis or further discussion on the role of the Chief beyond the description. Second, Mandelbaum's methodology is questionable since he explicitly relies on one key informant Kamiokisihkwew (Fine Day), with input from other informants, yet he is unclear how he obtains certain intimate and sacred information. For example, in the chapter The Individual Life Cycle, he details his observations during a birth ceremony, but he does not identify who is his source on this information. In other words, it appears that this section was based solely on his observations, and I do not feel that he would be able to understand this ceremony without the input from a woman. Furthermore, Russell (1991) showed that much of Mandelbaum's historical analysis was not based on evidence. Finally, at the 1975 Plains Cree conference Plains Cree Elders did not agree with Mandelbaum's assessment of the Plains Cree (Tootoosis, 1975). 
Venne's (1997) work is foundational because she is one of the first Indigenous scholars in the literature to analyze treaty from an Indigenous perspective. She questions the Canadian interpretation of treaty using three layers of logic; what would our ancestors want; what does our community want; and what do we want for the future. She argues that to understand treaty we must move beyond the written text and consider the Indigenous perspectives of Treaty. To do this, Venne reviews Cree oral histories of Treaty 6 and integrates Cree concepts. For example, Elders present at Treaty 6 recall the agreement being made between Indigenous nations and the Queen. As Venne (1997) argues, "the government of Canada, which is not a party to the treaty, does not have the authority to change the treaty" (p. 189). Furthermore, Venne points out that despite the historical disregard of the Treaties, treaties signify international status for Indigenous nations.

In addition to providing an Indigenous analysis of Treaty, Venne (1997) discusses several Cree governance theories and practices. First, she discusses the theoretical and practical foundation of Cree leadership. Okimâw (Chiefs or Headmen) are skilled and respected members of the community, selected based on their skills and knowledge. Second, she discusses the difference between peace and war Okimâw and uses details of Big Bear as an example of an Okimâw that could be both types of leaders (Venne, 1997). While Okimâw have power and authority, Okimâw are "only empowered to implement decisions made by their citizens" (p. 179). Leaders cannot act without the consent of their people. Thus, Cree governance is dynamic including both executive leadership and community-based governance. Third, Venne discussed the importance of ceremony in Cree governance. For the Cree, ceremony is not just a way to conclude political agreements, but ceremony and protocol represent the sacred nature of Treaty. 
Sacred agreements are the highest level of Cree law. Finally, Venne discusses the role of women in Cree governance.

Because of this spiritual connection with the Creator and Mother Earth, it is the women who own the land. Man can use the land, protect and guard it, but not own it. Women can pass on authority of use to the man, but not the life of the earth. When a man hunts, the women come along and claim the meat. If a woman is the Chief's wife, she distributes the choice meat in the village after the hunt, because the women own the meat and the hide.

To comprehend the role of women is to understand the limits placed upon the Chiefs in the negotiation of the treaty. The Chiefs did not go to the treaty table with unlimited authority to negotiate with the representatives of the Crown. Just as the Queen's commissioner was limited by the Crown's legislative authority, so too were the Chiefs limited.

The Chiefs who entered into treaty only had the authority to share the lands, never to sell or surrender it. One of the reasons women did not take on political roles such as Chief, or participate in the treaty-making process, was to protect their jurisdiction and possessory rights. Women never signed the treaties: they never signed away possession of the lands to the Crown. This is the main reason that the Elders and Chiefs can say with such authority that the land was never sold in the treaty process. (p. 191)

Venne's (1997) chapter is foundational to the field of Indigenous governance because she discussed Indigenous governance in Indigenous terms. In this short chapter, she succinctly analyzed theoretical and practical aspects of Cree governance. Despite this chapter being 20 
years old, this chapter continues to be relevant because her discussion is based on the living knowledge of Cree governance. This work serves as inspiration for me, since I want to take this approach and apply it to my people the Nehinuw.

In Treaty Elders of Saskatchewan, Cardinal and Hildebrandt (2000) explore the Indigenous understandings of the numbered treaties signed in Saskatchewan between Indigenous and settler societies. Since Treaty Elders of Saskatchewan was based on "seven Treaty Elders forums and numerous Elders focus sessions across the province of Saskatchewan with Elders from Dene, Cree, Assiniboine and Saulteaux Nations between 1997 and 2000” (p. vi), it is one of the most comprehensive sources of Saskatchewan Indigenous knowledge. While Treaty Elders of Saskatchewan (Cardinal \& Hildebrandt, 2000) focuses on the numbered treaties, the book explores the core aspects of Indigenous treaty theory and practice and is a valuable contribution to the field of Indigenous governance. The foremost contribution is Cardinal and Hildebrandt's discussion of Indigenous spirituality. Their analysis centres around the Cree concepts of Iyiniw sawêyihtâkosiwin (the peoples'sacred gifts) and Kihci-asotamâtowin (sacred promises to one another).

Iyiniw sawêyihtâkosiwin (the peoples'sacred gifts) is a Cree concept that refers to the connection between people and the creator. "The traditional teachings of the First Nations in Saskatchewan tell them that they are the children of the Creator" (Cardinal \& Hildebrandt, 2000, p.10). This teaching means that the Creator is the foundation of First Nations sovereignty and that this relationship "provided the framework for the political, social, educational, and cultural institutions and laws of their peoples that allowed them to survive as nations from the beginning of time to the present" (p.11). While Cardinal and Hildebrandt discuss Iyiniw sawêyihtâkosiwin 
as a concept that influences First Nations, the role of spirituality also influenced interactions with First Nations and settler society.

Next, they discuss the concept of Kihci-asotamâtowin (sacred promises to one another). The numbered treaties signed between the First Nations people of Saskatchewan and the Crown are examples of Kihci-asotamâtowin (sacred promises to one another). As sacred promises, treaties are "interwoven with and derive their existence from the spiritual and ceremonial fabric of First Nations societies" (Cardinal \& Hildebrandt, p.38). In other words, treaties are not merely political agreements, but they are international agreements that represent the foundation of Indigenous spirituality. To break Kihci-asotamâtowin is the most serious offence in the Indigenous worldview. Once you understand the significance of Indigenous spirituality, you start to see that the other theoretical components discussed in Treaty Elders are more than aspirational goals; these concepts are the theories of Indigenous governance. For example, Miyowîcêhtowin, the Cree principle that "individuals and nations conduct themselves in a manner that they create positive relationships" (p. 14), becomes the theoretical basis of international relations. The end goal is positive relationships reinforced by spiritual law.

Every Cree concept discussed in the book has similar implications. Wahkohtowin, which refers to the laws governing social relations and outlines the duties and responsibilities of each member of the family unit, is the theoretical framework for the governance of Cree families and communities. Wîtaskêwin, which refers to entering agreements to share the land, is the theoretical basis for resource sharing. Pimâcihowin, which refers to the spiritual, physical, and economic connection to the land and the ability to make a living, represents the holistic and interconnected view of these theories of Indigenous governance. In other words, Pimâcihowin, 
as a concept that centers around the land and the future, connects the spiritual nature of Indigenous governance with these other significant concepts.

While Treaty Elders is a foundational book for Indigenous governance, there a few limitations to this text. First, while all the governance theories and practices discussed are Cree, methodologically the book is based on the input of multiple Indigenous Elders from multiple Indigenous nations. Thus, it is unclear how the concepts translate between the various Indigenous nations. Furthermore, despite input from multiple Indigenous nations, Treaty Elders of Saskatchewan centers around Plains Cree knowledge. Second, the book focuses on a theoretical discussion of Cree concepts, but there is little explanation on how these theories are implemented in the contemporary context. For example, Miyo-wîcêhtowin is a theory and practice of maintaining good relations, but Treaty Elders looks specifically at the historical numbered treaties. How do you implement Miyo-wîcêhtowin in the contemporary context? Can new treaties be signed according to Miyo-wîcêhtowin? Finally, while women are recognized as sources in the book, their knowledge is utilized significantly less than men (Snyder, 2016). Thus, how would the knowledge change if women had been included equally or if the source relied only on women? Nevertheless, the theories and practices discussed in this book represent a living body of Indigenous knowledge on Indigenous governance with specific emphasis on Cree knowledge.

Makokis (2001), a Cree speaking woman from Saddle Lake First Nation, uses grounded theory to explore Indigenous knowledge and governance. Her study focuses on the Cree people of Saddle Lake First Nation in North-Eastern Alberta. She discusses a wide variety of Cree concepts such as love, worldview, ceremony, history, and governance. Her dissertation addresses how Cree concepts could be utilized within the self-government process. She refers to 
governance as "Iyiniw Pahminsowin". This conceptualization includes "Iyiniw", the Cree term for the people she studies and "Pahminsowin", which is translated into "to be in control or take care of" (p. 121). When put together, she suggests that "Iyiniw Pahminsowin" is how the Cree people control activities in their region. She uses the wheel as an analogy for the structure of Cree governance, noting that at the centre of the wheel is traditional knowledge and from all that knowledge flows Cree governance. Other works reviewed do not reference Iyiniw Pahminsowin or the wheel conceptualization of governance. In addition to Iyiniw Pahminsowin, Makokis (2001) discusses numerous other Cree governance concepts. Iyintoweyasowewina (Natural Laws) is a group of four laws including Kiseywatisowin (Love), Kweyaskatesowin (Honesty), Wichitowin (Sharing), and Sohkisowin (Strength). Kanawapaminkowina refers to the roles and responsibilities of individuals to follow the natural laws. These roles and responsibilities intersect with an individual's skills and role in their community. Makokis identifies nine roles that are part of Iyiniw Pahminsowin including “leadership, women's society, hunters, Elders, medicine persons, peacekeepers, gatherers, and criers" (p. 123).

Makokis' (2001) work is an example of an exploration of Indigenous governance in Indigenous terms, with a specific focus on the Cree perspective of Saddle Lake. She accomplished the goals of her dissertation, which were "what are the Cree core values and beliefs; how can these beliefs be used to change neo-colonial attitudes and then assist us to reshape our governance systems" (p. 185). Thus, this dissertation provides a strong discussion on Cree theory, the impact of colonization, and suggestions for the resurgence of Cree theory. The limitations with her work is that discussion of Cree theory is theoretical and there could have been more of an exploration of how this theory was implemented. For example, Makokis (2001) and her participants discussed the theory of Iyintoweyasowewina (Natural Laws), but what 
happened when Iyintoweyasowewina were broken and how would these laws be implemented in the contemporary setting. Furthermore, Makokis (2001) uses a wheel as an analogy for governance; the centre of the wheel is traditional knowledge and from traditional knowledge flows the system of governance. I would not use the wheel analogy because Indigenous governance is much more dynamic than a wheel with fixed parts and layers.

Jobin (2005, 2014), a Cree woman and member of Red Pheasant Cree First Nation, uses Cree concepts throughout her work. In her 2005 master's thesis, she analyzed the philosophies and governance structure of Bent Arrow Traditional Healing Society, a contemporary urban Indigenous cultural organization. She separates the concepts into two categories, philosophies and governance. Philosophies are the fundamental values and beliefs that guide the organization. For example, the medicine wheel is a guiding philosophy of Bent Arrow. The four directions of the medicine wheel symbolize specific values, including Îyinewiwin (Humanness), Ayamihewâtsowin (Spirituality), Kitimâkeyimowin (Passion), and Cikâstepekisin (Reflection) that an individual needs to maintain to achieve Miyo-wîcêhtowin (Good relationships). Governance is the way these values are implemented by specific individuals. For example, she discusses how Nîkânîwin (Leadership) conduct themselves according to the philosophies. Jobin's thesis (2005) provides a valuable separation of philosophies and governance, so it is possible to see the connection between theory and practice. The limitation of his work is that she focuses on a specific organization and not an Indigenous nation.

Jobin's (2014) doctoral dissertation does focus explicitly on an Indigenous nation. Her dissertation is an in-depth analysis of settler-colonialism. She argues that the Plains Cree people should resist settler-colonialism based on Cree philosophies including "principles such as mâmawi-hitêyihtamowin (thinking about all), manatisowin (civility), and kiskinowâpamewin 
(learning through observation), as well as practices such as emekinawet (gift-giving)" (p. iii). I agree with Jobin's approach, and I find the structure of her dissertation inspirational. However, while there is considerable use of Cree concepts throughout her work, the goal of this dissertation is to critique settler-colonialism. Thus, she uses Cree theory to critique settler colonialism. I think this is a valuable endeavor, but I am interested in work that explores Indigenous governance in Indigenous terms.

Hansen (2013), an assistant professor in Sociology at the University of Saskatchewan and a member of Opaskwayak Cree Nation, explored the Swampy Cree justice system asking, "what constitutes justice from an Omushkegowuk perceptive" (p.12). The Omuskegowuk people are the Swampy Cree people "who live in swampy areas throughout Northern Ontario, along James and Hudson's Bay) and northern Manitoba" (p. 12). Furthermore, the Omushkegowuk people speak "the N dialect of the Cree language" (p. 12). As mentioned above, his work explored Swampy Cree conceptions of justice. He does not claim that Swampy Cree justice is unaffected by colonization, rather that Cree knowledge is alive and still practiced by Elders. In terms of his analysis, Omushkegowuk justice is a system that closely "harmonizes with the philosophy of restorative justice or justice as healing" (p. 219). While Hansen provides a valuable analysis of the framework of Omushkegowuk justice, there is little discussion around Omushkegowuk concepts. He only discussed one Omushkegowuk term "Poonâ 'yétum", which translated means "not thinking about it anymore" (p.151). This concept is a restorative justice outcome in which someone forgives someone.

Goulet (2013), a Cree woman and member of Peter Ballantyne Cree Nation, examines the Cree legal traditions of two different Saskatchewan Cree communities, Cumberland House and Pelican Narrows. Her analysis focuses on assessing six Cree concepts including Onisinweuk, 
Wahkohtowin, Miyo-wîcêhtowin, Pâstâhowin, Ohcinêwin, and Kwayaskitotamowin.

"Onisinweuk refers to the people who keep the law" (p. 16). "Wahkohtowin was the overarching principle fundamental to understanding Cree values and legal principles" (p. 16). "Miyo-wîcêhtowin is a legal principle based on the relationship of the Cree with the Creator" (p. 17). This view of Miyo-wîcêhtowin differs from that put forward by Cardinal and Hildebrandt (2000); in their work Miyo-wîcêhtowin is the "laws concerning good relations" (p. 14). Pâstâhowin refers to the consequences of breaking "spiritual or natural law" (p.19). Ohcinêwin is "the negative consequences that flowed from a failure to abide by Cree law" (p. 19). In this framework, there are several punishments that could be prescribed depending on the crime. For example, Atameyimew (blame) might be the appropriate punishment. Kwayaskitotamowin refers to how the individual lives in accordance with Cree legal traditions. I am grateful that Goulet has taken the effort to discuss various Cree concepts, and I agree with her that these concepts need to be the foundation of revitalization. The main issue I have with this study is that the source of these Cree concepts is unclear and inconsistent. The thesis is meant to focus on Cree concepts identified in the historical Hudson Bay Company journals. However, when she discusses Onisinweuk, this concept comes from Borrows (2010) not the Hudson Bay journals. At the same time, why is there an emphasis on Cree concepts in text and no discussion with knowledge holders?

The Treaty Relations Commission of Manitoba has completed a comprehensive four volume series of Treaty Elders' Teachings. This project met with nearly every First Nation in Manitoba, held numerous focus groups and interviewed " 228 Elders from the seven Treaty areas and five Manitoba linguistic groups" (Treaty Relations Commission of Manitoba, 2016, para. 1). The research for this project began in 2006 and was completed in 2011. Volumes one and two 
were published in 2014, Volume three was published in late 2015, and Volume four was published in the end of 2016. These volumes contain a variety of Indigenous teachings from various Indigenous Elders across Manitoba including teachings on creation, law, sacred practices, social relations, language, and education. Of relevance for this dissertation is the section on "Kihche'othasowewin" (the Great Law), which is a code of twelve Nehetho laws and principles. The Nehetho are a group of Cree people in northern Saskatchewan and Manitoba.

1. Kwayaskonikiwin, means that the conduct of a person must be reconciled with Kihche'othasowewin.

2. Kistethichikewin, means that the conduct of a person must be based on the sacred responsibility to treat all things with respect and honour. In the context of road access management this means that a person must show respect by requesting access.

3. Tawinamakewin, means that a person is welcome. In the context of road access management this means that a person granting access has a duty to consider the land and its resources and has a duty to consult, including consideration for the well-being of the inhabitants. Therefore, the inhabitants will consider the request for access, including considering for the well-being of a person requesting access.

4. Aski Kanache Pumenikewin, which means that the conduct of a person must be in accordance with the sacred duty to protect N'tuskenan (the land, life, home and spiritual shelter entrusted to us by Kihche'manitou for our children michimahch'ohc (since time immemorial).

5. Ethinesewin, means traditional knowledge, including the influence of moons and season on climate, weather, animals, plants and Ethiniwuk (Individuals) as well as seasonal harvesting cycles and practices, there is a duty to respect and seek. 
6. N'totumakewin, means that a person must seek not to be understood but to first understand. It establishes a duty to teach, as well as to understand and to share, as well as to seek Ethinesewin.

7. Ayakwamisiwin, means that a person must be cautious of his or her actions where there is uncertainty.

8. O'chinewin, means what a person does to nature will come back to that person.

9. Aniskowatesewe Kanache Pumenikewin, means that a person must act in accordance with the sacred responsibility to protect heritage resources.

10. Kanatethechikewin, means that the conduct of a person must be in accordance with the sacred responsibility to ensure that Ethinewikuna (human remains) and Aniskowe Apuchetawina (artifacts; the things we use while here on Earth) must not be disturbed.

11. Asehewewin, means what a person does to Ethinewikuna (human remains) and Aniskowe Apuchetawina (artifacts) will affect that person's whole being.

12. Nehetho Tipethimisowin, means the exercise of sovereignty. The conduct of all persons must be consistent with Kihche' othasowewin and must reflect decisionmaking roles in accord with Nehetho Tipethimisowin. (Pratt, Bone, \& The Treaty and Dakota Elders of Manitoba, 2014, p. 32-33)

In addition to these twelve principles, in the glossary there is reference to additional governance concepts. "Itasowét - to govern, to make laws, and enforcing laws" (p. 132), “Tipínimisiwin; self-government” (p. 136), and "Wanascikáték; being set up, self-government laws" (p. 136), but there is no reference to the source or any further explanation of these concepts. While the Nehetho people are a different group than the focus of this dissertation, I am 
intrigued by the possibility of great law. I would like to know if my people the Nehinuw had a "Great Law" with a specific number of laws, because I see several concepts in this code that my people also use. For example, principle eight O'chinewin, is also a concept used by my people. My struggle with these resources is that there is little attempt to explain how this knowledge is used in practice. For example, what is the connection between principles one and two? This limitation is largely based on the format of this text, as the code is simply put on one page without any additional commentary from the Elder.

McAdam (2015), co-founder of Idle No More and a Nêhiyaw woman and citizen, discusses the framework of the Nêhiyaw legal system. Nêhiyaw is an Indigenous term used to refer to the group of people in Southern Saskatchewan and Alberta. While this book is titled Nationhood Interrupted: Revitalizing Nêhiyaw Legal Systems suggesting a specific focus on the Nêhiyaw, McAdam's book is designed to be a general guide on the protocols and methodologies of Indigenous law based on the input of Indigenous Elders and knowledge- keepers from various Indigenous nations including Dene, Nakawe, Lakota, Dakota, Nakota, and Cree. Nevertheless, McAdam does focus on many Nêhiyaw political concepts. She begins by discussing the role of Oskâpêws, which are "sacred helpers" (p. 17). The highest level the Nêhiyaw legal system is called Manitow wiyinikêwina. There are four components to Manitow Wiyinikêwina including human, earth, spiritual, and animal. The set of laws that apply specifically to human interactions called Nêhiyaw Wiyasiwêwina. In this model, there is a specific role for women called Okihcitâwiskwêwak. Women implemented laws, provided analysis on a case-by-case basis and carried children. The consequences of illegal actions in the Nêhiyaw legal system are referred to as Pâstâhowin, which means "the breaking of laws against another human being" (p. 43) and Ohcinêwin, which means "breaking of law against another other than a human being" (p. 44). 
McAdam also discusses traditional leadership selection. She notes that, "at the time of treaty making, a [leadership] structure was in place that involved selecting a 'Okimâw' (Chief) and his 'Onîkânîwak' (Headman)” (p. 80). Like other works discussed in this section, McAdam described the theories and practices of Cree governance while arguing that resurgence should be based on Cree theory. But how were these Cree theories implemented and how should these theories be implemented in contemporary Cree institutions. For example, she discusses the theory of Pâstâhowin "the breaking of laws against another human being" (p. 43). However, how was Pâstâhowin implemented? Whatare the punishments for breaking the laws of Pâstâhowin? Discussing the implementation of these theoretical concepts is important because this type of analysis would allow us to see how Pâstâhowin would be implemented in the contemporary context.

Wastesicoot $(2004,2015)$, a fluent Cree speaker and woman from Northern Manitoba, explored Cree spirituality and the impact spirituality has on law and self-governance. For her research, she participated in an Elder's gathering, conducted interviews, and reviewed historical records for references to Cree religion. Wastesicoot (2015) sees Cree spirituality as the core basis of the Cree people; therefore, law and governance flow from Cree spirituality. "Cree people's knowledge of spirituality and law requires an understanding of their belief system, known as Tapwetamowin, understood as faith that Cree people have carried in their "ways of knowing" (p. 24). Wanasiwewin is the central branch of Cree spiritual law and breaking this law results in "Pastahwewin" (sin) and Ojina (spiritual suffering)" (p. 63). There were several Okihtsitawak (societies/groups) of people that were responsible for peacekeeping. When a person has committed a crime, "it is usually the Elder who is knowledgeable about the old ways, who will say how to bring balance back. Most often a person will have to provide tipahikewin (payment) 
or pakitinasowin (offering) to the spirits to bring back harmony and balance" (p .166).

Wastesicoot's research provides valuable insights into Cree spirituality. While I agree that Cree spirituality needs to be the basis of Cree governance (2004, 2015), beyond the normative components of spirituality she does not analyze theories or practices of Cree governance.

The above literature explores various aspects of Cree governance theories and practices. However, much of this literature has focused on a specific group of Cree people, the Nêhiyawak (the Plains Cree), and the work on the Nehinuw has not explicitly analyzed Nehinuw governance in Nehinuw terms. I want to understand Nehinuw governance because I am Nehinuw and this perspective has not been explicitly explored in the literture. I hope this work challenges the homogenous view of Indigenous and Cree governance and provides new insight into the theory and practice of governance. More importantly, I want this work to protect the knowledge of Nehinuw governance for future generations as I believe that Nehinuw knowledge is threatened. In addition to this Cree focused literature, there is considerable amount of research that explores Indigenous governance theories and practices from the various Indigenous nations. Central to this literature is the robust amount of research that has analyzed Indigenous treaty theory (Alexie, 2011; Asch, 2014; Battiste, 2016; Borrows, 1997; Henderson, 1994, 2008a; Hill, 2008; Jacobs, 1991; Ladner, 2006; Macklem, 2001; McAdam, 2015; Palmater, 2016; Pratt, 2004; Tully, 1995; Simpson, 2008a; Williams, 1993). One perspective of Indigenous treaty theory is that treaties are agreements of "mutual respect and non-interference in each other's internal affairs" (Alfred, 1995, p. 140). At the same time, Indigenous treaties are international agreements to work together (Monture-Angus, 1999). Like the Cree perspectives, several other Indigenous nations across North America view treaties as sacred agreements between multiple parties (Miller, 2009). As sacred agreements, treaties are more than agreements between 
humans; treaties are the highest form of Indigenous law. The sacred components of these treaties have real implications. Finally, Indigenous treaties represented the mutual recognition of sovereignty between Indigenous nations (Opekokew, 1980). These theories were imbedded in Indigenous people's continual negotiation of treaties in good faith with the European powers (Asch, 2014; Miller, 2009). While there has been a tendency to dismiss Indigenous political theory and discuss treaty through the lens of the historical treaties, Indigenous treaty theories are so much more than agreements between Indigenous and settler societies. Treaties are living representations of Indigenous governance and sovereignty (Monture-Angus, 1999; Ladner, 2005), and knowledge of Indigenous treaty theory considerably adds to the field of political science.

Governance is another important topic in the field of Indigenous governance. Ladner (2003) provides a definition of Indigenous governance based on the Blackfoot worldview. Governance is "the way in which a people lives best together" or the way a people has structured their society in relationship to the natural world. In other words, it is an expression of how they see themselves fitting in that world as a part of the circle of life, not as superior beings who claim dominion over other species and other humans. (p. 125)

Scholars have explored specific theories and practices of Indigenous governance. The Inuit have dynamic community and spiritual decision-making processes and unique approaches to leadership (Fossett, 2001; Price, 2008). The Haudenosaunee/Mohawk/Iroquois have a specific code of conduct, Kaienerekowa (the Great Law of Peace), unique political institutions (Alfred, 1995; Fenton, 1998; Jacobs, 1991), and women leadership forums (Simpson, 2014). Ladner (2000, 2001b) analyzed Blackfoot nationalism and governance. For Ladner (2000), Blackfoot 
women played a central leadership role in Blackfoot governance. Belanger (2014) and Stonechild (2002) discussed the structure of various Indigenous alliances including the Iron Alliance. Battiste (1997) and Paul (2006) analyzed decision-making process of the Míkmaw Great Convention Council. Tssessaze (2007) and Keith (2013) assessed Dene governance and decision-making. Tssessaze (2007) focused on Dene governance concepts such as Thlaga Yati (community governance law). Alexie (2011) discusses the land-based practices of the Teetl'it Gwich'in as acts of self-governance and self-determination. She notes the challenge translating Indigenous ideas into academic language. Now there are increasing calls that one of the main goals of decolonization must be the revitalization of the theories and practices of Indigenous governance (Porter, 2005) in a way that is consistent with Indigenous knowledge. For example, Corntassel (2012a) argues that decolonization must be "about reconnecting with our relationships and renewing our roles and responsibilities within our communities" (p.87).

Clearly, there are multiple theories and practices of Indigenous governance and the theories and practices are diverse and complex. I would not be the first scholar to state there is a need for more Indigenous research on Indigenous governance (Irlbacher-Fox, 2009; Ladner, 2001b). However, since only a few sources have focused on the Nehinuw, exploring Nehinuw governance expands our knowledge of Indigenous governance. Goulet (2013) does focus on one Nehinuw community addressed in this dissertation, but her analysis is based on two different communities from two different Cree Nations. Other Cree sources (Cardinal \& Hildebrandt, 2000; McAdam, 2015; Pratt, Bone, \& The Treaty and Dakota Elders of Manitoba, 2014) identify many important Cree governance theories, yet these works are openly based on knowledge from various Indigenous nations. Therefore, do the identified governance principles apply to the Nehinuw? Finally, while the literature discusses the theory of Cree governance, there is not a lot 
of work that attempts analyze the implementation of Cree governance theories. I have designed this dissertation to attempt to address these gaps. This study explores Nehinuw governance in Nehinuw terms; thereby introducing the unique theory of Nehinuw governance into political science, governance, and policy studies, and identifies ways to implement this theory into practice. However, to understand Nehinuw governance it is critical to assess the impact contemporary policy, law and legislation has had on the practice and theory of Nehinuw governance. The next section of this chapter will assess these developments and how these developments have impacted Nehinuw governance.

\subsection{Colonization: Dispossession, Oppression, and Dependency}

Contemporary Indigenous governance is a combination of Indigenous and nonIndigenous theories and practices (Porter, 2005; Wilkins \& Stark, 2011), but understanding the impact of non-Indigenous governance is not as straightforward as analyzing a current Indigenous constitution, which has been done (Alcantara \& Whitfield, 2010). To understand the impact that non-Indigenous theories and practices have had on Indigenous governance, you must take a comprehensive look at the Indigenous-settler relationship. I want to begin this section by analyzing the foundational narratives of the Indigenous-settler relationship. I believe that colonization has always been the foundational intention of settler societies. Knowing that colonization is the foundational intention is important because colonization in the Indigenoussettler relationship has not simply been the establishment of permanent settlements.

Colonization in the Indigenous-settler relationship has resulted in the dispossession of Indigenous lands, the oppression of Indigenous people, and dependency of Indigenous people with the Canadian state (Alfred, 2001; Manuel \& Derrickson, 2015; Williams, 1993). Furthermore, establishing that colonization has always had these intentions provides the 
inspiration for the focus of this dissertation, which is to explore Indigenous governance in Indigenous terms.

For some, colonization does not begin until later in Canadian Indigenous relationship. Miller $(1989,2009)$ structures this relationship into four periods including contact, cooperation, coercion, and confrontation. Early cooperation is first based on commercial, peace, and friendship treaties. For example, the 1725-1779 treaties between the British Crown and Mi'kmaq secured peace and trade (Ladner, 2005). Henderson (1994) sees these treaties as the basis of Treaty Federalism or a nation-to-nation relationship between European and Indigenous people. Military cooperation was also common practice. For example, Indigenous nations were key allies in the War of 1812 (Belanger, 2005; Dickason, 2010). However, the only cooperation that ever existed was on behalf of Indigenous people based on Indigenous treaty theory (Asch, 2014; Cardinal \& Hildebrandt, 2000; Simpson, 2008a; Venne, 1997) because European treaties were ultimately designed to "lull [Indigenous] Nations into a false sense of security until an opportune time arose when they could dispossess [Indigenous people] of all they owned" (Paul, 2006, p. 85). Therefore, while I agree that elements of cooperation exist in early Canadian Indigenous relations, the Canadian Indigenous relationship has always been and should be classified as colonization. To view the Canadian Indigenous relationship as anything but colonization perpetuates the myth of Canadian benevolence (Regan, 2010) and ignores ongoing colonization.

The colonization of the Americas was justified based on the spread of religion and progress (Alfred, 2009b; Frideres \& Gadacz, 2012; Paul, 2006) and the philosophies of the doctrines of discovery and terra nullius (Aboriginal Justice Inquiry of Manitoba, 1999; Hoehn, 2012; McAdam, 2015, Venne 1998; Williams, 1993). The doctrine of discovery provides the 
fundamental justification for the erasure of Indigenous sovereignty and imposition of European governance systems. The doctrine of discovery is the premise that European nations could legally and unilaterally claim land from the Indigenous peoples of the Americas (Venne, 1998; Williams, 1993). Terra Nullius is the Eurocentric view that Indigenous lands were empty and "that no one owned the land prior to the European assertion of sovereignty" (Borrows, 2015, p. 702). While the legal and political reach of terra nullius and settler colonialism increased over a period of several centuries (Fitzmaurice, 2007), colonization immediately impacts the theory and practice of Indigenous governance because the underlying legal and political objectives after contact are based on the doctrine of discovery and terra nullius. Until the Canadian state and society revisits the original intentions of colonization, the legitimacy of the Canadian state is based on the acquisition of Indigenous lands. The unilateral acquisition of Indigenous lands is tenuous (Venne, 1998).

Post-contact Indigenous governance continued to operate based on Indigenous governance theories and practices. Stonechild (2002) discussed the structure and history of the Iron Alliance 1690-1885, which was an alliance in Central Canada between the Cree, Assiniboine, and Blackfoot. This alliance was based on Cree, Assiniboine, and Blackfoot political theories and practices. Other sources have discussed pre-confederate Indigenous governance, Ladner (2000) argued that Blackfoot nationalism predates European nationalism and is much more dynamic than European nationalism. Ladner (2005) also described how the Mi'kmaw maintained their sovereignty within the perspective of salmon fisheries. In other words, despite colonial interference, Indigenous governance continued to flourish. The legitimacy of Indigenous governance is independent of British or Canadian authority (Corntassel, 2012a; Monture-Angus, 1999) and based on Indigenous political theories and practices. 
The Royal Proclamation of 1763 is another significant event that impacts the theory and practice of Indigenous governance. In theoretical terms, the proclamation recognized the sovereignty of Indigenous nations and acknowledged Indigenous title (Alfred, 2001; Borrows, 1994, 1997; Opekokew, 1980; Pratt, 2004; Turner, 2007; Venne, 1998). For example, the Proclamation states that

Nations or Tribes of Indians with whom We are connected, and who live under our Protection, should not be molested or disturbed in the Possession of such Parts of Our Dominions and Territories as, not having been ceded to or purchased by Us. (The Royal Proclamation, 1763)

In addition to establishing Indigenous sovereignty and title, the Proclamation also recognizes Indigenous nations. For Henderson (1994) this creates nation-to-nation relationship based on the Indigenous right to self-determination. While there are various arguments for and against sovereignty (Alfred, 2005; Corntassel, 2012a, Monture-Angus, 1999), the idea of sovereignty is central to Indigenous governance. For Porter (2005), "sovereignty is the power of a people to control their own destiny" (p. 100). In contrast, Corntassel (2012a) has strong reservations against state forms of sovereignty, "given the colonial history of state" (p. 90). Corntassel does not completely reject the idea of sovereignty, rather he would like to see sovereignty implemented within frameworks of Indigenous knowledge. I agree with this position, and I hope to support this goal by exploring Indigenous governance in Indigenous terms.

In practical terms, the Royal Proclamation states the intention and legality of subsequent governments to acquire Indigenous lands (Alfred, 2001; Borrows, 2015; Christie, 2007; 
Dickason, 2010; Henderson, 1994; Isaac, 2012, Isaac \& Annis, 2010; Leslie, 2002). This point is stated further on in the Proclamation,

And We do further declare it to be Our Royal Will and Pleasure, for the present as aforesaid, to reserve under our Sovereignty, Protection, and Dominion, for the use of the said Indians, all the Lands and Territories not included within the Limits of Our said Three new Governments, or within the Limits of the Territory granted to the Hudson's Bay Company, as also all the Lands and Territories lying to the Westward of the Sources of the Rivers which fall into the Sea from the West and North West as aforesaid. (The Royal Proclamation, 1763)

The Royal Proclamation was the principle framework used by subsequent settler-colonial powers until the 1976 Supreme Court of Canada Calder case. The underlying logic of the Royal Proclamation is that Indians had title to their lands and that it was in the interest of the Crown to acquire this land. The result was a series of treaties designed specifically to acquire land for the Crown (Borrows, 2001; Hanson, 2009). However, Indigenous people dispute this view of treaty (Asch, 2014; Battiste, 2016; Borrows, 1997; Cardinal \& Hildebrandt, 2000; Christie, 2007; Hoehn, 2012; Palmater, 2016; Venne, 1997, 1998). Instead, treaties were agreements to share the land with settlers and Indigenous peoples. Yet, the logic of Royal Proclamation was used by the Crown to justify the usurpation of Indigenous lands. Over time, the usurpation of land led to the elimination of Indigenous sovereignty as Indigneous peoples have consistently had to struggle for international recognition (Lightfoot, 2016; Nichols, 2005). The land/sovereignty connection is even more problematic when one considers that Royal Proclamation treaties only acquired a specific part of Canadian territory, largely central Canada (Asch, 2014; Manuel \& Derrickson, 
2015). In other words, the logic of the Royal Proclaimation has had a profound impact on the creation of the Canadian state.

The Royal Proclamation continues to play a central role in Canadian's constitutional order. Without the Royal Proclamation and subsequent treaties, the Canadian state's "use and occupancy of [Indigenous] lands" (Venne, 1997, p. 206) is illegitimate. As Venne (2016) eloquently argued, how can the Canadian constitution claim to maintain peace, order, and good governance without Indigenous participation. Furthermore, since the historic treaties have now been reinforced by the constitution (Borrows, 1998; Miller, 2009), any abrogation of the treaties is a violation of Canadian law (Peach, 2009; Townshend, 2013). Of course, there is currently no mechanism to charge Canadian governments when they violate the treaties they have made with Indigenous nations. For example, the federal government is responsible for the health care needs of status and treaty Indians. This responsibility originates from the constitution and a stipulation in Treaty 6 to maintain healthcare on-reserve. Yet, every year many status and treaty Indians are denied health care coverage due to a provincial/federal jurisdiction debate over the provision of health care services (Blackstock, 2012; Canadian Human Rights Tribunal, 2016).

One of the key issues with the Post-Royal Proclamation treaties surrounds the concepts of honour, spirit, and intent. The Canadian government maintains that they have honoured the spirit and intent the historic treaties. For example, in terms of the treaty right to education, the Canadian government has focused on funding education "to bring First Nations participation rates to a level comparable to the rest of society" (Stonechild, 2006, 1. 2333) instead of addressing the broader implications of the treaty right to education. As Stonechild (2006) argues, the spirit and intent of the educational components of the treaty suggest a state of the art education system for the time. Yet, the Canadian government has narrowly interpreted the 
educational aspects of treaty. Indigenous people have consistently argued that the Canadian government does not fully honour the spirit and intent of the historic treaties (Mercredi \& Turpel, 1993; Monture-Angus, 1999; Palmater, 2000; Stonechild, 2006).

Treaty discouse is clearly intertwined with the Royal Proclamation and the Canadian constitutional order. Treaty discouse is also central to Indigenous governance as numerous Indigenous scholars have stressed the importance of treaties (Henderson, 1994; Venne, 1997). As I have explored Indigenous political theories and practices in more detail, I wonder if the treaty discouse risks reinforcing settler-colonialism because the primary outcome of the treaty discouse is to assess the relationship between Indigenous and settler societies. In my recent analyses of these historical treaties, I attempt to look only at the Indigenous theories and practices of treaty. The Cardinal and Hildebrandt (2000) text is an essential resource that has helped me understand Indigenous treaty theory. When we look at treaties through the lens of Indigenous people, treaties become political tools of the past and the future. In that respect, I look to the historical treaties to ask what the theoretical basis of these treaties is and how can that knowledge be used in future treaties.

While the British government recognized a nation-to-nation relationship in theory following the Royal Proclamation, eventually the British government openly rejected any nationto-nation guarantees. This shift occurred in 1830, when British representatives argued that it was time to "ameliorate the condition of the Indians" (Miller, 1989, p. 100). To achieve this objective, the British government proposed to concentrate Indians on reserves, subject them to schooling, and provide them with agricultural training (Miller, 1989). The Indian Department was established at that time to oversee these goals (Milloy, 2008). While policy at the time was primarily concerned with acquisition of Indian lands, civilization and amelioration were 
established goals of Indian policy (Darcy, 2004; Dickason, 2010; Grammond, 2013). For example, in 1857 the British government passed the Act to Encourage the Gradual Civilization of the Indian Tribes in the Province (Milloy, 2008). Thus, began an era in which the British and Canadian governments would slowly eliminate Indigenous governance theories and practices.

The 1867 British North America or Constitution Act was the next major development for Indigenous governance. This Act created the Dominion of Canada. A dominion was an invented concept used to describe "a regime that was too self-governing to be considered a colony but not entirely independent of the mother country either" (Malcolmson, Myers, Baier, \& Bateman, 2016, p. 23). Canada's first constitution largely dealt with the structure and powers of the Canadian government. Of specific relevance for Indigenous governance are sections 91 and 92 of the constitution that create the division of powers between the federal and provincial government. There are two implications of the jurisdiction created by these sections. First, section 91(24) of the Act provides the Federal government authority over Indians and lands reserved for Indians (Palmater, 2011a). This transfer of authority sets the template for the paternalistic governance of Indigenous people as nation-to-nation was replaced with a specific fiduciary authority defined by the constitution (Milloy, 2008). Recently, the Daniels v. Canada (2016) concluded that the Indians in section 91(24) "includes all Aboriginal people, including non-status and Métis" (p.112). Although, Gaudry and Andersen (2016) argue that judicial logic of the Métis definition in this case is racially and historically problematic. The second implication of section 91 and 92 deals with powers not covered by these sections. Justice Williamson concluded that "Aboriginal rights formed part of the unwritten principles underlying [the Constitution Act 1867]" (Campbell v. British Columbia, 2000, para. 70) and "the Constitution Act, 1867 did not distribute all legislative power to the Parliament and the 
legislatures" (para. 180). In other words, despite the Crown's acquisition of land and sovereignty, the rights of self-government have never been extinguished (Dalton, 2006). The 1867 Constitution is a source of written paternalism and unwritten recognition.

Within nine years of confederation, the Canadian government continued to increase its control over Indigenous society by passing the 1876 Indian Act. While the Indian Act was not the first piece of legislation to use the term "Indian", see the Gradual Enfranchisement Act of 1869, the Act consolidated existing legislation and continues to be the central "Indian" policy (Miller, 2009; Palmater, 2011a). Some literature has a neutral view of this Act, highlighting its history of military alliances; attempt to manage the influx of settlers; and protection of Indian lands (Coates, 2008; Indian and Northern Affairs, 1978; Miller, 2009). Marule (1984) and Kundook (2014) discussed how Indigenous decision-making processes have been incorporated in Indian Act governments. Other scholarship does not have the same view of the Indian Act (Aboriginal Justice Inquiry of Manitoba, 1999; Crane, Mainville, \& Mason, 2008; Imai, 2007; Milloy, 2008). Instead, the Indian Act is viewed as an "unacceptable basis for the relations between First Nations and Canada" (Mercredi \& Turpel, 1993, p. 80). The Indian Act has had a profound impact because the Act comprehensively controls Indigenous societies by imposing Euro-Canadian values and institutions ranging from property ownership, identity, inheritance, fixed territories, non-Indigenous legal system, democratic elections, and fixed term leadership (Abele, 2007b; Aboriginal Justice Inquiry of Manitoba, 1999; Coulthard, 2014; Crane, Mainville, \& Mason, 2008; Grammond, 2013; Kulchyski, 1993; Mercredi \& Turpel, 1993; Milloy, 2008; Palmater, 2000, 2011a; Sanderson, 2014). Furthermore, Indigenous scholars and Elders reject the Indian Act because it was established after Treaty (Leslie, 2002; Venne, 1997) and the Act makes no mention of Treaties (Jobin, 2014). 
Since the Indian Act has been amended multiple times and the impact of the Act is comprehensive and ongoing, it has been a challenge to appropriately place a discussion on the Indian Act. I have decided to discuss the governance implications of the Indian Act at this point, even though some of the amendments were not implemented until later because I agree that the underlying policy objectives of the Act have not changed since it was originally passed (Abele, 2007b; Hurley, 2009; Leslie, 2002). Firstly, the language of the Indian Act has had a profound impact on Indigenous governance. I am using the term Indigenous on purpose because the Act makes an explicit statement on Indigenous identity and governance. The Indian Act erased Indigenous conceptions of identity by explicitly defining who is an Indian. Furthermore, the original definition of "Indian" was sexist. The identity of Indian women was dependent on their marriage status (Palmater, 2011a) and Indian women could not vote in Band elections and run for Council until 1951 (McCallum \& Klassen, 2017). While the overtly gender discriminatory aspects of the act were removed following the 1985 Bill C-31 Indian Act amendments, based on the two new categories of Indian status and current marrying out rates, it is projected that within seven generations there will be no more status Indians (Daniels, 1998; Palmater, 2011a). "Gender discrimination is only one of several types of discrimination currently found in the Indian Act's registration and band membership provisions" (Palmater, 2011a, p. 103). Palmater (2011a) notes that cousin, second generation cut-off, unstated paternity, sibling, and Métis scrip are additional forms of discrimination under the Indian Act. Thus, in defining who is an "Indian", the Canadian government simultaneously eliminated the role women played in Indigenous governance (St. Denis, 2007; Venne, 1997), homogenized the diversity of Indigenous nations, and controlled Indigenous identity. 
In addition to controlling identity, the Indian Act (1985) uses the term "band" to refer to specific groups of Indians. Like the homogenizing effect of "Indian", the use of "band" diminished the diversity of Indigenous governance. Bands are the central political unit in the Indian Act and the governments of bands are referred to as "Band Councils". According to section 74(2) of the Indian Act (1985), band councils consist of "one chief, and one councillor for every one hundred members of the band". There is some variance on the exact composition of Band Councils as there are four potential Band Council structures recognized by the Canadian government including the Indian Act structure mentioned above or a structure outlined in the custom election code system, the First Nation Elections Act, or a structure created by selfgovernment agreement (Indigenous and Northern Affairs, 2016a; Simeone \& Troniak, 2012; Wastesicoot, 2015). While there are four potential Indian Act Band Council structures, a close reading of the Act shows that bands are municipal style governments that exist within the Canadian Federal democracy (Abele, 2007b; Alfred, 2001, 2009a; Borrows, 2008; Jobin, 2014; Monture-Angus, 1999; Venne, 1997). Thus, instead of recognizing Indigenous governance theories and practices, the Act forced a specific vision of governance onto Indigenous people. Indian Act governance fragmented Indigenous nations into specific groups and eliminated Indigenous leadership theories and practices.

Authority of Indigenous governance has been completely removed under the Indian Act (Abele, 2007b). There is no mention of the creator or any other Indigenous authority in the Act. The Minister of Indian and Northern Development maintains the broad powers throughout the Indian Act. The Act limits the jurisdiction of bands to minor matters on reserve. Section 81(1) outlines 22 areas of jurisdiction that the Chief and Council can regulate with by-laws. For example, Chief and Council has authority to "provide for the health of residents on the reserve 
and to prevent the spreading of contagious and infectious diseases", "destruction and control of noxious weeds", and "regulation of bee-keeping and poultry raising". Section 83 provides additional on money by-laws and how this money can be expended. Despite the various areas of authority identified by the Indian Act, none of this authority empowers Indian bands since the minister always maintains the right to approve or disapprove any by-law.

Indigenous decision-making theories and practices have also been removed under the Indian Act. In addition to the areas of by-law authority mentioned above, the government provides guidance for the procedures of band council meetings in the Indian Band Council Procedure Regulation (2009). This additional regulation defines the order and proceedings of band council meetings. Decisions are made according to the majority, and final decisions, referred to as Band Council Resolutions, are formally submitted to the minister for approval. First Nations decisions to enact membership codes and decide on absolute or conditional land surrender are made based on consent of a majority of electors through referendums. This decision-making process is not representative of Indigenous decision-making theories and practices as First Nations have followed, ignored, and adapted to this structure in multiple ways. Abigosis (2003) explored how one community developed a constitution based on traditional philosophies and contemporary process. Baptiste (2007) and Horn-Miller (2013) discuss how several First Nations implemented Indigenous decision-making processes. Under these models, Indigenous consensus is not about unanimity, rather Indigenous consensus is about participation and understanding by all community members including not just those who are voting age.

While some of the restrictive aspects of the Indian Act have been removed (Coté, 2001; Gibson, 2009; Indian and Northern Affairs, 1978; Miller, 1989), the framework of the Act has not changed (Hurley, 2009; Leslie, 2002). Under the Act, Indigenous people are viewed as 
"wards of the state" (Belanger, 2005, p. 5). Prime Minister Macdonald felt "Indians were like children; they were like persons under age, incapable of the management of their own affairs and, therefore, the government had to assume the 'onerous duty of ... guardianship"” (Milloy, 2008, p. 7). Little Bear, Boldt, and Long's (1984) analysis that "Indians would become part and parcel of the Canadian political system" (p. xi) remains to be a valid view of Indigenous governance under the Indian Act. For example, leaders are selected by a democratic majority vote instead of recognizing leaders for their knowledge and skill (Dempsey, 2006; Mandelbaum, 1979; Venne, 1997). Paternalism becomes cultural genocide when overtly restrictive elements are added to the Indian Act following the 1885 Northwest Rebellion. For example, cultural celebrations, legal counsel, Indigenous political structures, and travel off reserve are prohibited to quell any Indigenous resistance (Barron, 1988; Belanger, 2005; Leslie, 2002). For the moment, I will leave this discussion on the Indian Act to discuss other important developments that occurred chronologically.

Another key component of Canadian colonization policy was the Indian Residential School system. I will not discuss all physical, biological, cultural and social impacts of the residential school system because there has been so much valuable work on this topic (Milloy, 2001; Regan, 2010; Truth and Reconciliation Commission of Canada, 2012, 2015). However, I will briefly discuss the impact residential schools had on Indigenous governance. The Truth and Reconciliation Commission of Canada (2015) stated that the Indian residential school system was cultural genocide because it destroyed "the political and social institutions" (p.1) of Indigenous people. The residential school system was designed to erase the connections that Indigenous people had with their culture and identity. For example, children were not allowed to speak their Indigenous languages and specific Euro-Canadian values were imposed. The 
residential school system crippled Indigenous societies, and we are still seeing the impacts of intergenerational trauma (Regan, 2010). The loss of language and knowledge and the imposition of Euro-Canadian values has had an impact on Indigenous governance. First, the survival of the language is critical since knowledge of political theory is contained in language (Viatori \& Ushigua, 2007). Thus, the loss of language and knowledge decreased the knowledge of Indigenous governance. Second, the residential school system imposed "Christian ideologies of gender and gender relations" (St. Denis, 2007, p.46). Shifting gender values impacted the role of Indigenous women within Indigenous governance theories and practices.

Intertwined in this era of overt colonization is a 1930 amendment to the Constitution known as the Natural Resource Transfer Agreement (NRTA). The NRTA is a series of three agreements to transfer the Federal jurisdiction of land and natural resources to the provinces of Manitoba, Saskatchewan, and Alberta (Calliou, 2007; Mochoruk, 2007; Tough, 1995, 2004). From 1930 onwards, provincial governments had constitutional jurisdiction over lands and natural resources. An amendment, such as the NRTA, that impacts livelihood, treaty, and land, had a significant impact on Indigenous governance. The central concern for Indigenous peoples is that natural resources were not covered in treaties signed prior to the 1930 NRTA (Cardinal \& Hildebrandt, 2000; Venne, 1997). Thus, the NRTA illegally transferred natural resource authority to provincial governments (Tough, 1995, 2004). However, the Supreme Court of Canada has upheld the validity of the NRTA. For example, in Frank v. the Queen (1978), a case that dealt with treaty and hunting rights between provincial boundaries, the Crown supported the transfer of jurisdiction to the provincial government.

On December 14, 1929, an agreement between the Government of Canada and the Government of Alberta (the Natural Resources Transfer Agreement) transferred 
from Canada to Alberta the interest of the Crown in all Crown lands, mines and minerals within Alberta. The agreement was approved by the Parliament of Canada (1930 (Can.), c. 3) and by the Legislature of Alberta (1930 (Alta.), c. 21) and thereafter it was confirmed by the Imperial Parliament by the British North America Act, 1930. (Frank v. the Queen. 1978, p. 98)

Indigenous organizations have held national summits on this issue to develop strategies to challenge the NRTA (Wallace, 2012). Yet, Saskatchewan provincial government has continually rejected resource sharing with First Nations (APTN National News, 2015). The validity of this constitutional amendment may not face a challenge since the issue of infringement does not exist until after 1982 when Aboriginal and Treaty rights were affirmed in the constitution and addressed in R. v. Sparrow (1990).

Aside from the significant moral and legitimacy issues with the NRTA, the transfer can be critiqued in terms of practically. Without a significant land base and resource revenue sharing agreement, the operation of Indigenous governance is dependent on Federal funding. For example, despite Indian band having access to several types of funding including funds from various levels of government, settlement funds; own-source revenue; litigation funds; and taxation money on reserve or settlement lands, a majority of the funding for Indian bands are Federal transfers (Richards \& Krass, 2015). Thus, without an independent land base or revenue source, Indigenous governments will continue to be reliant on federal transfers. Dependency is not the type of independence desired by Indigenous people (Alfred, 2009b; Corntassel, 2012a). Finally, the transfer of jurisdiction, created by the NRTA, gave provincial governments considerable bargaining power in the negotiation of modern Indigenous governance agreements. The NRTA limits the future of Indigenous governance. I do not have any creative solutions to 
deal with the NRTA, but the only meaningful way forward is one based on Indigenous knowledge, which is the impetus for this dissertation, to explore Nehinuw governance in Nehinuw terms.

After the NRTA and until the end of the Second World War, Indigenous people were not on the Canadian political agenda. Yet, following the Second World War, Canadian Indigenous policy started to change indirectly. In this era, the Canadian state was engaged a period of social and political renewal as Canada's role in the War solidified itself as a major international power, the Canadian government had championed the development of international human rights, and there was a greater concern for social welfare (Borrows, 2005; Cairns, 2005; Giokas, 1995). At the same time, Indigenous political organizations continued to lobby the federal government to address the major socio-economic problems faced by Indigenous people (Belanger, 2005; Leslie, 2004). While the Canadian government did not extend to support "Aboriginal rights, demands that Indian treaty promises be honoured, [or] the settlement of land claims" (Leslie, 2004, p. 17), the concern for welfare led to changes to Canadian Indian policy.

In 1951, the government unveiled major changes to the Indian Act that repealed and introduced several important governance aspects of the Indian Act governance (Hurley, 2009). In addition to omitting the prohibition on cultural celebrations, the 1951 Act repealed a section that required "anyone soliciting funds for Indian legal claims obtain a license" (Giokas, 1995, p.50) from the Superintendent-General, allowed life chiefs, and omitted the male gender provision for chiefs and councilor candidates. Additions to the Act included an Indian register, new rules on band council financial by-laws, and two-year term for chief and council (Giokas, 1995; Milloy, 2008; Venne, 1981). These changes had profound practical and theoretical implications for Indian and Indigenous governance. No longer requiring Indians to obtain a 
license meant that Indians could legally pursue land claims. As we will discuss further on in this chapter, this change begins a new era of Indigenous legal activism that continues to challenge the legal and political authority of the Canadian state. Furthermore, omitting the male gender from chief and councilor opens the door for women to run for these positions (McCallum \& Klassen, 2017). Yet, the new two-year term for chief and council continues to restrict Indigenous leadership theory. At a much broader level, the 1951 changes inspire Indigenous political activism to ending control of the Federal government (Giokas, 1995). Some Indigenous political organizations reassert their authority (Alfred, 1995; Manuel \& Derrickson, 2015). Other First Nations communities began the land claim process opened by the amendments (Leslie, 2002). Finally, many Indigenous political organizations began to focus on the idea of Indian government on Indian terms using the concept of self-government (Belanger \& Newhouse, 2004; Johnson, 1984). For the moment, I will not completely address the issue of self-government, but I do want to emphasize that the idea of Indigenous governance in Indigenous terms emerges following the changes to the Indian Act in 1951.

While the 1951 Indian Act did not fundamentally alter the status quo of Canadian Indigenous policy, which was still focused on assimilation, the issue of Indian welfare did not leave the Canadian political agenda. In 1964, Prime Minister Pearson tasked the HawthornTremblay Commission "to study Indian social, economic, and political issues" (Leslie, 2004, p. 21). The final 1967 Hawthorn-Tremblay Report suggested a "Citizens Plus" approach to Indigenous rights. Under this approach, Indigenous peoples were Canadian citizens with additional charter benefits such as Treaty rights (Belanger, 2014; Cairns, 2000). The report was groundbreaking since it tried to consult with Indigenous people and "Citizens Plus" advocated shifting away from assimilation law and policies (Belanger \& Newhouse, 2004). Ultimately, the 
policy reforms of the Hawthorn Report were rejected with the election of Pierre Trudeau's government.

Despite Indigenous optimism, Prime Minister Pierre Trudeau renewed his government's commitment to the assimilation of Indigenous people and termination of Indigenous rights. Trudeau rejects this commitment to assimilation by framing his commitment under the premise of equality, liberalism, and multiculturalism. As Trudeau claimed, "it's inconceivable, I think, that in a given society one section of a society should have a treaty with the other section of society. We must all be equal under the laws and we must not sign treaty amongst ourselves" (as cited in Borrows, 2002, p. 103). Thus, he argued for implementation of a liberal rights regime of multiculturalism or the creation of a "Just Society" (Belanger \& Newhouse, 2004; Cardinal, 1969; Henderson, 2006). The philosophy of the Just Society was embodied in the Statement of the Government of Canada on Indian Policy or, as it came to be known, the 1969 White Paper (Coulthard, 2014; Gibson, 2009; Turner, 2007). "The White Paper [proposed] that Indian status be eliminated and...collective [rights be] abandoned in favour of the individual and full ordinary citizenship" (Gibson, 2009, p. 5).

First Nations people rallied against Pierre Trudeau's proposed termination plan and began articulating various perspectives of First Nations rights. The first response came from the Indian Chiefs of Alberta in their Citizens Plus paper, which came to be known as the "Red Paper". In the Red Paper, the Indian Chiefs of Alberta argued that the Canadian government was bound by the British North American Act, which asserted Federal responsibility for Indians and Indians lands, and that the government must respect the obligations of the treaties (Belanger \& Newhouse, 2004; Indian Chiefs of Alberta, 2011). Many other organizations and individuals would soon release statements of Indian rights articulating various positions on Indian people 
gaining greater control over Indian affairs (Association of Iroquois and Allied Indians, 1971; Cardinal, 1969; Indian Tribes of Manitoba, 1971; National Indian Brotherhood, 1972; Union of British Columbia Indian Chiefs, 1970). In addition to articulating the idea of Indian selfgovernment, these organizations also overtly rejected Pierre Trudeau's white paper policies (Indian Chiefs of Alberta, 2011). Non-Indigenous scholarship takes a more pragmatic approach to Indian rights following the collective Indian resistance. Boldt and Long (1984) preferred a model of Indigenous governance that did not "provoke a full-scale power struggle with the Canadian Government” (p. 553). Cairns (2000) argues that many Indian organizations wanted a model based on the "Citizens Plus" approach, which has been previously proposed in the 1967 Hawthorn Report. Citizens Plus is an assimilation model that recognizes Indigenous rights but only within the Canadian legal framework (Cairns, 2000). Despite the differences in the language of the Indian responses, the central idea within the various perspectives promoted Indian governance in Indian terms.

Even though the White Paper was never officially implemented, the status quo Canadian Indigenous policy framework was never that much different from the assimilation and termination policy agenda of White Paper. A troubling precedent that developed shortly after the 1969 White Paper was the reappearance of the assimilation and termination policy agenda in the Canadian courts. The 1973 Calder case provided the government renewed prerogative for termination. In theory, Calder et al. v. Attorney-General of British Columbia (1973) appeared to be a major victory for Indigenous rights. The Calder decision recognized that Aboriginal title existed pre-contact "confirming that a separate system of Aboriginal rights" (Belanger \& Newhouse, 2004, p. 141) and that Aboriginal rights derive from occupation and possession (McNeil, 1997). For example, the Court concluded that "the Nishgas are the owners of the lands 
that have been in their possession from time immemorial" (Calder et al. v. Attorney-General of British Columbia, 1973, p. 375). Furthermore, the recognition of Aboriginal title compelled the Canadian government to alter its status quo approach to resource extraction. At the time, the federal and provincial governments did not need to legally consider Indigenous title. For example, the Quebec government approved the hydrological development of the James Bay without consulting the local Indigenous people. As Manuel and Derrickson (2015) note, "it was the Calder decision, with its recognition of the existence Aboriginal title, that forced the Quebec government to put the bulldozers into idle and climb down to talk" (1. 941).

Yet in practice following the Calder decision, the Canadian government unofficially implemented the assimilation and termination agenda of the White Paper. Shortly after the decision, the Canadian government developed two problematic land claim policies, specific and comprehensive. Specific land claims deal with specific failures of previously negotiated treaties. Since 1973, 1240 specific claims have been completed and 433 have been settled (Indigenous and Northern Affairs Canada, 2017e). As for comprehensive land claims, Indigenous nations negotiate the surrender of Indigenous title and any claims they may have over a large section of land in exchange for financial compensation, greater political certainty, and title to a smaller section of land (Kulchyski, 2005; Manuel \& Derrickson, 2015). Numerous Indigenous people have critiqued these agreements and the Royal Commission on Aboriginal People (1996) critiqued both land claim processes and advocated for structural change. Within two years of the 1973 Calder decision, the James Bay Cree were compelled to negotiate a comprehensive agreement to allow a hydroelectric project in their Northern Quebec territory (Manuel \& Derrickson, 2015). The Cree and Inuit of James Bay surrendered title to their land and agreed not to pursue further claims in court (Coon Come, 1995). As Manuel notes, compelling 
Indigenous people to surrender their title contradicts fundamental principles of international law, which Canada helped to draft (Manuel \& Derrickson, 2015). Despite these contradictions, the Canadian government used the 1975 James Bay and Northern Quebec Agreement as a template for subsequent land claim policies. Since 1975, 30 comprehensive land claims have been signed and 58 are currently being negotiated (Indigenous and Northern Affairs Canada, 2016b). The 1986 Sechelt Indian Band Self-Government Agreement was the first comprehensive agreement to use the "self-government" language. However, from the Calder decision forward, selfgovernance has two meanings depending on context. Self-governance in Indigenous terms is an unsurrendered, inherent, and self-determined right that provides Indigenous nations with sovereignty and title. The Canadian Indigenous governance framework uses a form of selfgovernance that is dependent on Canadian sovereignty and title.

The 1982 Constitution Act was the next major development in Indigenous rights. Section 35 (1) states "the existing aboriginal and treaty rights of the aboriginal peoples of Canada are hereby recognized and affirmed" (Constitution Act, 1982, 35.1). Section 35 (3) provided additional clarification that the treaty rights of 35 (1) "includes rights that now exist by way of land claims agreements or may be so acquired" (35.3). The inclusion of section 35 was a major win for Indigenous people since Aboriginal and Treaty rights were now protected by the supreme law of Canada. The legal protection meant that governments could not easily change Aboriginal and Treaty rights since such a change would now require the implementation of the rigorous amending formula (Asch, 2014). Furthermore, recognizing and affirming Aboriginal and treaty rights created "new contexts for interpretation of government responsibility" (Henderson, 1994, p.244). However, there is growing recognition that section 35 did not alter the assimilation and termination agenda of the Canadian Indigenous governance framework. 
Section 35 impacted Indigenous rights in multiple ways, but I will focus on how this section impacted Indigenous governance. First, Section 35 created a new category of Indigenous people, Aboriginal. The recognition of three groups of Aboriginal people, Indian, Inuit, and Métis, created political tensions between these groups. In the buildup to Section 35, Indigenous groups worked together (Manuel \& Derrickson, 2015); however, once recognition was achieved Métis and First Nations political organizations dispute the implications of Aboriginal and Treaty rights (Belanger, 2014). In addition to creating a new category of Indigenous people, Section 35 does not define the Aboriginal rights that were recognized and affirmed. Thus, it is unclear what are Aboriginal rights. Do Aboriginal rights include the right to self-government? Subsequent constitutional discussions and supreme court cases failed to address if Section 35 included the right of self-government (Belanger \& Newhouse, 2004; Borrows, 1998; Cardinal, 1969; Gibson, 2009; Hurley, 2009; Mercredi \& Turpel, 1993; Turner, 2007). Second, the recognition of Indigenous rights within the Canadian constitution is problematic for Indigenous people because Indigenous people see their rights originating prior to and outside of any Canadian authority (Coulthard, 2014; Henderson, 1994; Ladner, 2005, 2009; Napoleon, 2007; Turner, 2007). Thus, despite entrenchment of Aboriginal and Treaty rights, the Canadian state maintained final authority over these rights (Asch, 2014). Furthermore, as is noted in Section 35(3), the future negotiation of "treaty rights" will only lead to rights that exist underneath the Canadian constitution. This position was affirmed in the 1995 inherent right to self-government policy. Moreover, negotiation was the only way to achieve the potential rights recognized in section 35(3). Negotiation has been costly, ineffective, and problematic (Coulthard, 2014; Ladner, 2001a; Royal Commission on Aboriginal Peoples, 1996). The process of negotiation selfgovernment through the extinguishment of title contradicts fundamental principles of 
international law (Manuel \& Derrickson, 2015), such as the International Covenant on Civil and Political Rights (1966), which states that "the States Parties to the present Covenant, including those having responsibility for the administration of Non-Self-Governing and Trust Territories, shall promote the realization of the right of self-determination, and shall respect that right, in conformity with the provisions of the Charter of the United Nations" (Article 1.3). Thus, instead of recognizing and affirming the diversity of Indigenous governance theories and practices, Section 35 maintained the status quo assimilation and termination approach of the Canadian Indigenous governance framework.

Despite the limitations of Section 35, defining self-government dominates Indigenous politics and the Indigenous governance literature following the 1982 Constitution. The 1983 Report of the Special Committee on Indian Self-Government, also known as the Penner Report, “recommended that First Nations' right to self-government be explicitly stated in the Constitution, that the Federal government recognize a distinct First Nations order of government and [that the government] work towards implementing self-government” (Hurley, 2009, p. 1). Furthermore, the Penner Report concluded that "Indian Nations have always been selfgoverning” (Belanger \& Newhouse, 2004, p. 154). Little Bear, Boldt, and Long (1984) argued that Indigenous self-governance is based on self-determination, sovereignty, and nationhood. The structure of Indigenous self-government is dependent on the Indigenous nations. Now, there were a series of "negotiations to define the content of a constitutional right of Aboriginal selfgovernment" (Hurley, 2009, p. 1). There was optimism that these subsequent constitutional talks will recognize Indigenous governance as a separate pillar of governance (Peach, 2011). However, these constitutional talks fail to produce any further guarantees for Indigenous governance. The closest the Canadian government came to recognizing self-government was in 
the failed Charlottetown Accord. The Charlottetown Accord would have amended the Constitution to recognize the right of self-government (Hurley, 2009; Isaac, 1992; Peach, 2011).

While the scope of Indigenous self-government was debated, the Supreme Court of Canada produced another precedent-setting case that impacted Indigenous governance, Guerin v. The Queen (1984). First, the Guerin decision labeled Indian title as Sui Generis (unique) (Borrows \& Rotman, 1997). "It is true that the sui generis interest which the Indians have in the land is personal" (Guerin v. The Queen, 1984, p. 382). Even though the case explicitly focused on a First Nations claim, the decision references aboriginal, native, and Indian title. The existence of title is important for Indigenous governance and rights because it justifies "some inherent form of self-government" (Foster, 1992, p. 344). Second, the Court also recognized that the Crown has "a distinctive fiduciary obligation to deal with the land for the benefit of the surrendering Indians" (Guerin v. The Queen, 1984, p. 387). In other words, the Canadian government must act in the best interest of Indians when dealing with Indian lands. While providing some additional protections for Indigenous rights, the Supreme Court reinforced its limited view by arguing that the Crown has ultimate title. Thus, fiduciary obligation is a continuation of Canada's paternalistic approach to Indigenous rights.

R. v. Sparrow (1990) was another significant Aboriginal rights case that had implications on Indigenous governance. Sparrow was the first Supreme Court decision on Section 35 (Isaac, 1993) and the Supreme Court decided that the Aboriginal rights of Section 35 should be interpreted "flexibly" and "liberally" (R. v. Sparrow, 1990, p. 1076). The use of these terms suggested that the Supreme Court would allow for a broad interpretation of Aboriginal rights protected by Section 35, including the right to self-government. However, instead of using a flexible and liberal approach on Aboriginal self-government, the Supreme Court did the opposite 
and provided a narrow interpretation of Aboriginal self-government. The precedent Aboriginal self-government case is R. v. Pamajewon (1996). In this case, the Supreme Court concluded that "the gambling activities, and the bands' regulation of those activities do not fall within the scope of the aboriginal rights protected under s.35(1)" (p. 837). By focusing specifically on the gambling activities and not addressing the broader question of self-government the Court proves that it is both inflexible and specific in its interpretation of self-government and disregards the guidance outlined in Sparrow. Furthermore, if the Supreme Court was aiming to liberally and flexibly protect Indigenous rights, why has the Supreme Courts developed processes, such as those in Sparrow (1990), Van der Peet (1996), and Delgamuukw (1997), for the government to infringe upon Indigenous rights? The logic of infringement suggests that the legitimacy of Indigenous legal orders are not respected. The legitimacy of Indigenous legal orders is central to the idea of Indigenous governance in Indigenous terms. If both the Canadian government and courts disregard the legitimacy of Indigenous governance, what type of governance is section 35 meant to recognize and affirm?

These Supreme Court cases highlight fundamental disagreements over power and authority between Indigenous and Canadian society. The disagreements continued to rise until the 1990 standoff at Oka. The Oka standoff, which was the result of a long history of Mohawk land appropriation by settler governments (Alfred 1995; Swain 2010; York \& Pindera 1991), internationally embarrassed the Canadian government and forced the government into action. Following the Oka standoff, the Mulroney government proposed to renew the relationship between Canadians and Indigenous people by forming a Royal Commission to address this issue (Belanger, 2014). 
The Royal Commission on Aboriginal People (RCAP), which lasted from 1991-1996 and heard from thousands of Indigenous people across the country, tabled its final report in 1996 with hundreds of suggestions to renew the relationship. After considerable effort and resources (Cairns, 2000), the final recommendations of RCAP proposed a complete revision of the Canadian Indigenous relationship. The report provided numerous recommendations related to Indigenous governance (RCAP, 1996). For example, the final report recommended: Passage of an Aboriginal Nations Recognition and Government Act; elimination of the Department of Indian Affairs and establishment of a new Department of Aboriginal Relations to negotiate and manage agreements with Aboriginal nations; and passage of an Aboriginal Parliament Act to establish a representative body of Aboriginal peoples that would evolve into a House of First Peoples and become part of Parliament. (Hurley, 2009, p. 2)

RCAP continues to be the most comprehensive research project, consultation, and attempt to address the Canadian Indigenous relationship. If the recommendations of RCAP had been implemented, the Canadian Indigenous relationship would have taken significant steps towards decolonization. For example, the creation of a third order of government, specifically for Aboriginal people, may have provided a forum for Indigenous governance theories and practices to flourish. Yet, few of the recommendations have been implemented (Âpihtawikosisân, 2012, Institute on Governance, 2015; Ladner, 2001a). RCAP commissioner Paul Chartrand argued that the relationship between Canada and Indigenous people has not changed since the release of the final report (Troian, 2016). Despite the aspirations of RCAP, the problem with the final recommendations was that they were framed within the Canadian state and Euro-Canadian institutions. For example, how would the creation of a single Aboriginal 
order of government, which is part of Canadian federalism, support the multiple governance theories and practices of Aboriginal peoples? The creation of an Aboriginal order of government would have only recreated the settler colonial mentality that views Aboriginal people as one homogenous people and leaves no room for the multiple governance theories and practices of Aboriginal people. Ladner (2001a) referred to RCAP's governance vision as “negotiated inferiority" (p.241). Thus, the recommendations did not go far enough to recognize Indigenous knowledge, which is the type of revision that is needed to renew the relationship. Why would there be the need to create a new order of government when these orders have existed outside of Canadian government since time immemorial.

In response to RCAP, the Canadian government developed a self-government policy, titled Approach to implementation of the inherent right and the negotiation of Aboriginal selfgovernment (Aboriginal Affairs and Northern Development Canada, 2013). This policy added the concept of the inherent right to self-government to the established comprehensive land claims process (Abele \& Prince, 2006; Asch, 2014; Belanger \& Newhouse, 2004; Hoehn, 2012; Rynard, 2000). While the self-government language had been previously used in the comprehensive land claims process, the addition of inherent right suggested a shift in Canada's paternalistic approach to self-government. However, an analysis of this policy shows that only the language was changed while the underlining paternalistic objective was maintained.

The first issue with this policy is that the Canadian government shifts the meaning of inherent rights. Inherent rights cannot be delegated, and they are fundamental to the livelihood of a people claiming these rights. Furthermore, identifying self-government as an inherent right, frames the inherent right of self-government as a basic human right entitled for broad jurisdiction and implementation through the framework of self-determination (McNeil, 2007). However, the 
inherent rights policy specifies that self-government only exists under Section 35 of the Canadian Constitution (Belanger \& Newhouse, 2004; Diabo, 2016; Indian Affairs and Northern Development, 1997; Manuel \& Derrickson, 2015; Rustand, 2010). Effectively, the Canadian government changed the meaning of inherent rights. Under this policy, the inherent right of selfgovernment will only exist as delegated by the Canadian state. This shifted meaning creates confusion and misdirection in the field of Indigenous governance. The Canadian policy contains the language of self-government and inherent rights; yet, the meaning of these words is not consistent with the meaning of inherent rights and self-government. In other words, selfgovernment has different meanings depending on the context. Indigenous activists, such as Russ Diabo, have shown that the current Canadian Indigenous governance framework is nothing more than the implementation of a termination plan designed "to end First Nations constitutional and legal rights" (Diabo, 2016, p. 7).

In addition to this shifting meaning of inherent rights, the policy is problematic because recognition of the inherent right of self-government can only be achieved through litigation or negotiation. Litigation may provide a successful outcome, but the result will only be made within the terms of the Euro-Canadian justice system. As we have seen from past cases, the courts continue to uphold the supremacy of Canadian governance by recognizing Canadian sovereignty and title over Indigenous claims (Borrows, 2015; Christie, 2007; Dalton, 2006). For example, in Delgamuukw v. British Columbia (1997) the Supreme Court developed a procedure for the federal and provincial government to infringe on Indigenous rights.

The aboriginal rights recognized and affirmed by s. 35(1), including aboriginal title, are not absolute. Those rights may be infringed, both by the federal (e.g., Sparrow) and provincial (e.g., Coté) governments. However, s. 35(1) requires that those 
infringements satisfy the test of justification. (Delgamuukw v. British Columbia, 1997, p.1107)

While the Delgamuukw deals with the infringement of Aboriginal rights, Indigenous governance is part of the rights protected by Section 35. In other words, litigation has provided little protection for Indigenous governance. The best Indigenous people can hope for is a court that attempts to bridge the gap between the two governance systems (Borrows \& Rotman, 1997; Borrows, 2015). The Canadian courts cannot recognize Indigenous governance as sovereign because that would admit that the Canadian governance order is illegitimate. As Napoleon (2007) argues it is impossible for a legal system to admit that it is illegitimate.

The government's preference is to negotiate the inherent right to self-government. I mentioned above that it is a contradiction to have delegated inherent rights. This contradiction also applies to the negotiation of inherent rights. By their nature, one cannot negotiate inherent rights, they either exist or they do not. Yet, in the current framework, Indigenous nations can only negotiate for their inherent rights. For example, the Tsawwassen First Nation final agreement states,

Tsawwassen First Nation asserts that it has an inherent right to self-government, and the Government of Canada has negotiated self-government in this Agreement based on its policy that the inherent right to self-government is an existing aboriginal right within section 35 of the Constitution Act, 1982. (Tsawwassen First Nation, 2007, p. 1)

Negotiation is problematic because this process can only be achieved by terminating other rights, specifically land rights. Since termination is the end goal of negotiation, this policy violates international law. For example, the Charter of the United Nations states, "members 
...[should] develop self-government, to take due account of the political aspirations of the peoples, and to assist them in the progressive development of their free political institutions" (Charter of the United Nations, 1945, para.3). Furthermore, negotiation of self-government in exchange for greater certainty over land title violates fundamental principles of Indigenous law, specifically Indigenous treaty theory based on sharing the land (Cardinal \& Hildebrandt, 2000: Venne, 1997). Finally, negotiating self-government has been inefficient, costly and unproductive (McNeil, 2007; Morse, 2008; Peach, 2009; Weaver, 1997) contrary to the "harmonious relationship" (Aboriginal Affairs and Northern Development Canada, 2013, para. 4) put forward by the federal government. The spirit and recommendations of RCAP gave the Canadian government an opportunity to renew the relationship with Indigenous people. However, instead of developing a framework that is consistent with Indigenous visions of self-government (Alfred, 2001; Belanger \& Newhouse, 2004; Blackburn, 2009; Christie, 2007; Coon Come, 1995; Foster, 1999; Manuel \& Derrickson, 2015; Palmater, 2011a; Patterson, 2006; Rynard, 2000; Simon, 2009; Weaver, 1997), the inherent rights policy does not make space for Indigenous governance theories and practices, and negotiating the termination of the inherent right of self-government is not a political aspiration of Indigenous people.

Shortly after RCAP and the inherent rights policy, the supreme court made an important concession on Indigenous governance. In R. v. Van Der Peet (1996), the supreme court recognized that Indigenous governance existed prior to Canadian governance and has not been extinguished in certain cases (Christian, 2009; Keal, 2007; Nicol, 2010; Pitty \& Smith, 2011; Sanders, 1975). For example, the Supreme Court conceded that First Nations had "pre-existing customs, laws and political institutions" (Morellato, 2008, p. 61). The Court also framed their decision within the context of traditional knowledge. 
"Traditional laws" and "traditional customs" are those things passed down, and arising, from the pre-existing culture and customs of aboriginal peoples. The very meaning of the word "tradition" -- that which is "handed down [from ancestors] to posterity", The Concise Oxford Dictionary (9th ed. 1995), implies these origins for the customs and laws that the Australian High Court in Mabo is asserting to be relevant for the determination of the existence of aboriginal title. To base aboriginal title in traditional laws and customs, as was done in Mabo, is, therefore, to base that title in the pre-existing societies of aboriginal peoples. This is the same basis as that asserted here for aboriginal rights. (R. v. Van der Peet, 1996, p. 546)

While the Court recognized "pre-existing culture" and not Indigenous sovereignty, Henderson (2006) sees the acknowledgment of pre-existing culture as an argument for Indigenous sovereignty. If there is a pre-existing culture, then that culture must also have basic rights of self-determination. Self-determination is the basis of sovereignty. Furthermore, the Canadian state has used the pre-existing culture of Indigenous people to further Canadian sovereignty claims (Broadhead, 2012; Coon Come, 1995; Loukacheva, 2009; Nicol, 2010). For example, "Inuit were coerced to leave their homelands, deserted in an alien environment more than 1,500 kilometers farther north, and used as 'human flagpoles' to bolster Canada's sovereignty claims in the Queen Elizabeth Islands" (Wakeham, 2014, p. 85). In other words, Canada's usage of Indigenous sovereignty to reinforce its sovereignty suggests that Indigenous people can also claim sovereignty (Christie, 2007; Nichols, 2005; Robbins, 2010). Yet, when it comes to recognizing Indigenous sovereignty, the Canadian government has only recognized a framework of Indigenous governance that exists in Canadian law (Coté, 2001; Nichols, 2005; Peach, 2009) and is dependent on Canadian sovereignty and title (Alfred, 2001; Gibson, 2009; 
Manuel \& Derrickson, 2015; Rynard, 2000). The logic of Canadian law and policy denies Indigenous governance theories and practices by denying Indigenous interpretations of selfdetermination, sovereignty, and title (Borrows, 2015; Venne, 1998; Zacher, 2001). In denying Indigenous people self-determination, sovereignty, and title, the Canadian government denies its own self-determination and self-governance because the Canadian state uses the same principles (self-determination, sovereignty, and title) to support its unilateral claim to govern all territory within its boundaries. Addressing this denial of fundamental human rights would require a revision of the Canadian state, yet there has never been the political will to address these fundamental premises of colonization, which is ultimately why Canada continues to be a settlercolonial state. One might point to the positive rhetoric surrounding the current government's Indigenous governance framework, which includes all the language of change such as a commitment to implement UNDRIP. Yet, the framework continues to see Indigenous governance only existing within the Canadian framework. This approach is the same issue that has plagued Canadian response to Indigenous governance since contact. Canada does not have any role in legitimizing Indigenous governance.

The duty to consult is another complicated development in the field of Indigenous governance. The duty to consult framework was established by Haida Nation v. British Columbia (2004) case and further developed in Taku River Tlingit First Nation v. British Columbia (2004) and Mikisew Cree First Nation v. Canada (2005) (McNeil, 2005). The Supreme Court ruled that "the government has a legal duty to consult with the Haida people about the harvest of timber from Block 6, including decisions to transfer or replace Tree Farm Licenses" (Haida Nation v. British Columbia, 2004, p. 520). In other words, the Canadian government has a legal obligation to work with Indigenous communities on issues of resource 
development. While the duty to consult framework is not meaningful, focuses on resource development, and does not give Indigenous communities a veto on resource development, the governance implication is that there is a legal precedent for nation-to-nation relationship between Canada and the Indigenous nations.

In addition to legal and policy developments, the Canadian government has recently passed several controversial bills including the First Nations Fiscal Management Act (2006), Jobs and Growth Act (2012), the First Nations Financial Transparency Act (2013), and the First Nations Elections Act (2014). The First Nations Fiscal Management Act (2006), originally titled the First Nations Fiscal and Statistical Management Act, created a system of taxation powers for First Nations Band and Council on reserve lands. Diabo (2004) argued that this bill was "consistent with the long-term federal Liberal goals of assimilating First Nations and the eventual termination of First Nation rights” (p.1). The Jobs and Growth Act (2012), often referred to as the Omnibus Budget Bill C-45, introduced numerous changes but Indigenous people were specifically against changes to the Indian Act, Fisheries Act, Canadian Environmental Protection Act, and the Navigable Water Protection Act. The Indian Act was amended to provide the Minister of Indigenous Affairs considerable influence over the surrender of reserve lands (McAdam, 2015; Palmater, 2015). The Jobs and Growth Act (2012) faced the strongest Indigenous opposition. McAdam (2015) argued that this legislation will "undermine the sovereignty and inherent rights of Indigenous peoples by focusing on individual rights, legislatively extinguishing treaty and Indigenous sovereignty" (p. 90) by effectively providing the Federal government the ability to lease Indigenous land. Similarly, Amnesty International (2012) released a statement critizing this legislative package. Palmater (2015) succinctly argues against the modern legislative framework stating that "the solution to chronic underfunding of 
essential human services like water, food, and housing lies not in more legislation but in addressing the problem" (p. 162). The Jobs and Growth Act or Bill-C45 was the inspiration for the grassroots Indigenous political movement Idle No More. When Bill C-45 was first announced by the conservative government, Indigenous women including Jessica Gordon, Sylvia McAdam, Sheelah McLean, and Nina Wilson organized a public event to discuss the impacts of Bill C-45, including the changes the bill was going to make to the Indian Act and on environmental protection (Idle No More, 2012). Idle No More quickly grew into an international defense of Indigenous nationhood (McAdam, 2015; Palmater, 2015). The First Nations Financial Transparency Act (2013) required that First Nations under the Indian Act make audited and public financial statements. Diabo (2013) contended that the Jobs and Growth Act and the First Nations Financial Transparency Act were designed to advance "individual rights to undermine collective or group rights, rather than encouraging a balance between individual and collective rights" (p. 2). Finally, the First Nations Elections Act (2014) provided detailed amendments to the Indian Act electoral system. While there were numerous changes, these changes did not empower First Nations electoral systems, rather the changes only created minor procedural impacts. For example, term of office was change from two years to four years. Overall, the recent suite of Canadian Indigenous governance legislation continued paternalistic model of governance that is based on recognition of Indigenous governance underneath the Canadian constitution.

In addition to the legal and political developments in the field, many non-Indigenous voices have written about the challenges and prospects of Indigenous governance. Early historical writings viewed Indigenous people as savages who are incapable of social and political organization (Nichols, 2005; Wastesicoot, 2015). When Indigenous governance writing started 
to emerge, for example the work of Mandelbaum (1979), there was little attempt to incorporate Indigenous knowledge or voice (Stevenson, 2000). Academia has viewed Indigenous governance as hypothetical (Franks, 1986; Nichols, 2005) and often ignored its theoretical contributions (Ladner, 2001b). According to these voices, Indigenous people and Canada would be better off if Indigenous people would assimilate into mainstream society and abandon any benefits they have accrued through treaty, legislation, and law (Alcantara, 2003, 2007; Cairns, 2000; Flanagan, 2000; Flanagan \& Alcantara, 2004; Flanagan, Alcantara, \& Dressay, 2010; Murphy, 2009; Poelzer \& Coates, 2016). In the best-case scenario, non-Indigenous scholarship simply acknowledges that Indigenous people have not been included (Russell, 2017).

Some of the non-Indigenous voices premise their work on benefiting the greater good of Canadian society. For example, Flanagan, Alcantara and Dressay (2010) argue that eliminating the current collective land ownership regime would benefit First Nations. They state that shifting to an individual, fee simple/private property, model would allegedly benefit First Nations communities. This shift would allow Indigenous people to leverage Indigenous land into significant investments (Flanagan \& Alcantara, 2004). However, I question the motives of their research since their past scholarship has argued against Indigenous rights (Flanagan, 1983, 1985) and for assimilation (Flanagan, 2000). These non-Indigenous voices do not consider the profound theoretical and practical implications of their proposals. The fee simple/private property model is not consistent with the theory of Indigenous land ownership (Alexie, 2011; Cardinal \& Hildebrandt, 2000; Corntassel, 2012b; Gunn, 2007; Henderson, 2002; Hill, 2008). Furthermore, how would this model protect the existing land base of First Nations people?

Some of this literature provides a neutral analysis of the Canadian Indigenous governance framework. Cairns (2000) resurrected the "Citizen's Plus" approach used in 1967 Hawthorn 
Report. Under this model, Indigenous people are Canadian citizens while acknowledging past benefits covered by treaty, legislation, and law. Alcantara and Whitfield (2010) analyzed "14 modern Aboriginal constitutions" (p. 127) that were created by "a modern treaty and/or selfgovernment agreement" (p. 128) and suggested that Indigenous and non-Indigenous constitutions are almost identical in structure and design. Similarly, some research (Alcantara \& Nelles, 2014; Papillon, 2012) has described the historical multilevel governance regime of Canadian and Indigenous governments. Papillon (2012) argued that Canadian Federalism has recognized Indigenous governments "through the layering of new multilevel governance (MLG) regimes that coexist with the existing division of powers and intergovernmental relation system” (p. 291). These neutral efforts to analyze the Canadian Indigenous governance framework do not consider the deeper theoretical issues within the field of Indigenous governance; specifically, what is Indigenous governance in Indigenous terms.

One barrier for Indigenous governance that is often not considered in the literature is Canadian society. Canadian society is a significant roadblock for Indigenous governance because society does not understand or accept the goals of Indigenous political theories (Ladner, 2005; Regan, 2010; Townsend, 2013). While Canadian society has evolved considerably since the founding fathers were elected and there were public debates on the assimilation of Indigenous peoples (Milloy, 2001, 2008), the tensions between Indigenous and Canadian societies have been consistent throughout history (Ladner, 2017; Russell, 2017). Nongovernmental organizations have argued that Indigenous rights threaten Canadian democracy and individual rights (Gibson, 2009; Neu \& Therrien, 2003; Rustand, 2010). The Environics Institute for Survey Research, which was commissioned by several organizations including the National Centre for Truth and Reconciliation to review Canadian public opinion on Aboriginal 
peoples, found that there is "clear evidence of a more understanding and supportive perspective" (Environics Institute for Survey Research, 2016a, p. 1) on Aboriginal issues. At the same time, the research concluded that the Canadian public is not open to any drastic changes to the relationship (Environics Institute for Survey Research, 2016b; Martin \& Adams, 2000; Poelzer \& Coates, 2016). The lack of understanding has repeatedly developed into violence against Indigenous people. For example, racism quickly erupted in Saskatchewan after a nonIndigenous farmer shot and killed Colten Boushie, a young Indigenous man, on his property in August 2016 (Canadian Press, 2016; Friesen, 2016). While there are many non-Indigenous allies, the lack of understanding and acceptance is a significant problem because Canada is a representational democracy and we continue to see elected and appointed government officials openly ignorant to the history of Indigenous peoples. What do these tensions mean for Indigenous governance? Tensions represent a continued unwillingness to accept the legitimacy of Indigenous governance. Terra nullius, which is the Eurocentric principle used to justify the acquisition of Indigenous lands over 400 years ago, has been normalized.

I am not suggesting that we need a tensionless society. Rather, the issue is that Canadian society has had numerous chances to renew/decolonize the relationship with Indigenous people and done little. Following WW2, the Canadian government was instrumental in the creation of international human rights and Canadian society was interested in these principles (Belanger, 2014; Cairns, 2000). Yet, the elected representatives of Canadian society continued to allow the residential school system to operate at peak efficiency, which was achieved in 1956-57 (Truth and Reconciliation Commission of Canada, 2015, p. 63). For example, the 1967 Hawthorn Report suggested that the poor socio-economic standing of Indigenous people should lead to greater recognition of Indigenous rights. Among the recommendations were that "Indians should 
be regarded as "citizens plus"; in addition to the normal rights and duties of citizenship, Indians possess certain additional rights as charter members of the Canadian community" (Cairns, Jamieson, \& Lysyk, 1966, p.13). Yet, within two years the elected representatives of Canadian society proposed the termination of Indigenous rights in the 1969 White Paper. While the White Paper was never formally adopted, the spirit of the White Paper continued to influence Canadian Indigenous policy. The Canadian government ignored the recommendations of RCAP by introducing the inherent right to self-government policy. Canadian society has continued to elect governments that do not address the foundational issues. This historical progression ends with two promising developments in the Canadian Indigenous governance framework, UNDRIP (2007) and the Truth and Reconciliation Commission's Final Report (2015).

UNDRIP is "the Indigenous equivalent to the United Nations Declaration on Human Rights [and] the Declaration establishes the essential standards for the recognition and protection of the world's 370 million Indigenous peoples' inherent rights" (Belanger, 2011, p. 133). The declaration provides protection for individual and collective components of Indigenous rights. Indigenous people long advocated for the recognition of their individual and collective rights. For example, Little Bear, Boldt, and Long (1984) called for a system of Indigenous governance based on the inherent rights of self-determination. Article 4 of the declaration states that "Indigenous peoples, in exercising their right to self-determination, have the right to autonomy or self-government in matters relating to their internal and local affairs, as well as ways and means for financing their autonomous functions" (United Nations, 2007, p. 4). For Henderson (2008b) UNDRIP has the potential to transform not only Indigenous governance but human consciousness. He sees the declaration as an instrument that forces Indigenous people to reconsider the fundamental purpose of Indigenous knowledge and philosophies. Despite the 
transformative power of the declaration (Christian, 2009; Kuokkanen, 2012; Maaka \& Fleras, 2008; Shadian, 2006), Canada has not implemented this declaration into law.

Finally, Truth and Reconciliation Commission Final Report (2015) issued 94 calls to action, which were primarily recommendations to address the legacy of the residential school system. However, these calls to action were also designed to "advance the process of Canadian reconciliation" (p. 319). The calls to action that address reconciliation have major implications for Indigenous governance and the Canadian Indigenous governance framework. Call to action number 3 recommends that all levels of government implement Jordan's Principle.

Jordan's Principle is a child-first principle intended to resolve jurisdictional disputes within, and between, provincial/territorial and federal governments concerning payment for services to First Nations children when the service is available to all other children. It was named in memory of Jordan River Anderson, a young boy from Norway House Cree Nation, who spent more than two years unnecessarily in hospital while Canada and Manitoba argued over payment for his at-home care. (Blackstock, 2012, p. 368)

Perhaps the most pointed calls to action that specifically address the Canadian Indigenous governance framework are number 43, implementation of UNDRIP, and number 45, a Royal Proclamation of Reconciliation based on the Royal Proclamation of 1763, designed to "reaffirm the nation-to-nation relationship between Aboriginal peoples and the Crown" (Truth and Reconciliation Commission of Canada, 2015, p. 326), and "repudiate concepts used to justify European sovereignty over Indigenous lands and peoples such as the Doctrine of Discovery and terra nullius" (p. 325). Yet, the Canadian government and society have not implemented these recommendations. 
The Government of Canada's official policy Approach to Implementation of the Inherent Right and the Negotiation of Aboriginal Self-Government states, "the inherent right of selfgovernment ... will not result in sovereign independent Aboriginal nation states" (Aboriginal Affairs and Northern Development Canada, 2013, para 6). Canadian sovereignty is used to justify the expropriation of Indigenous lands (Rollo, 2014). Canadian economic interests conflict with Indigenous claims to land and self-determination (Barker, 2009). The Supreme Court has preferred negotiation to recognition (McNeil, 2004), has not enhanced state of Aboriginal rights (Henderson, 2006), and continues to utilize the logic of terra nullius (Borrows, 2015). Some scholars have argued for the dismantling of Indigenous rights (Flanagan, 1985; Flanagan, Alcantara, \& Dressay, 2010). However, Canadian society prefers a model of Indigenous governance that exists underneath Canadian law (Ladner, 2009; Rustand, 2010). Since the underlying objectives have not changed, Ladner's (2014) description of the Canadian Indigenous governance framework as "political genocide" (p.228) is appropriate because the Canadian Indigenous governance framework has operated within the spirit of termination, and Canadian society has done little except provide vague and limiting recognition of Indigenous rights.

What about the progress? Is the recognition, reconciliation, and accommodation that Indigenous people have gained enough to say that the Canadian state has achieved decolonization? Critical Indigenous scholars have challenged the progress. Coulthard (2014) argues that the Canadian regime of recognition and accommodation continues on the fundamental basis of colonization. Corntassel (2012b) describes the current regime of Indigenous-Settler politics as the politics of distraction. Within the politics of distraction, the state shifts attention away from the resurgence of Indigenous knowledge to state-centric forms of recognition. As I reflect on the story of Indigenous governance, Corntassel's use of the politics 
of distraction is an accurate framework to view the field of Indigenous governance. The Canadian government and society, and even parts of Indigenous society, have become distracted from the resurgence of Indigenous knowledge. While I want my work to focus specifically on the resurgence of Indigenous knowledge and governance, more work is still needed to decolonize the Canadian Indigenous governance framework. In the next section, I explore the interconnections between decolonization and resurgence. It is critical to review the decolonization and resurgence literature because this literature is foundational to this dissertation. Ultimately, I focus on resurgence because this dissertation focused explicitly on Nehinuw knowledge of governance. I will explore five resurgence strategies to situate this dissertation and to show how these strategies have impacted Indigenous governance and this dissertation.

\subsection{Resurgence as Decolonization}

During the early 1900s Indigenous activism was primarily focused on resisting colonialism (Belanger, 2005). Yet, as civil and human rights discourse emerged in the 1950s and 1960s, there was also a reemergence of Indigenous thought. This reemergence manifested itself in the intellectual development of Indigenous studies. The development of Indigenous studies is significant because the first voices of Indigenous studies, such as Vine Deloria Jr. and Leroy Little Bear, argued that Indigenous knowledge was valid (Belanger, 2014; Deloria Jr. 1969,1972). Gradually, the field evolved into an interdisciplinary study of Indigenous knowledge, culture, and history. The reemergence of Indigenous thought is one of the defining features of the field of Indigenous studies. Central to the reemergence is the concept of resurgence, which is "about reconnecting with homelands, cultures, and communities" 
(Corntassel, 2012b, p. 97). Alfred (2009b) refers to resurgence as "the holistic reconnection of people to each other and to the land" (p .59).

Since decolonization focuses on the undoing of colonization, resurgence is critical act of decolonization. The danger of decolonization is that it focuses on the actions of the state instead of the resurgence of Indigenous knowledge (Corntassel, 2012b; Smith, 2000). Thus, decolonization and resurgence are often treated as separate concepts and processes. However, Corntassel (2012b) sees decolonization and resurgence "as interrelated actions and strategies that inform our pathways to resistance and freedom" (p. 89). I feel they are interrelated because decolonization is not simply achieved through independence from the colonizer (Fanon, 1963, Memmi, 1967). Decolonization requires a psychological and emotional commitment to undo the impacts of colonization and avoid the recreation of the colonial situation (Alfred, 2009a; Coulthard, 2014; Fanon, 1963; Smith, 2012; Tuck \& Yang, 2012; Turner, 2007). Laenui (2000) suggests that there are five stages of decolonization, "rediscovery and recovery, mourning, dreaming, commitment and action" (p. 152). These stages help the individual undo the longterm legacy of colonization. I agree that there are many interconnections between decolonization and resurgence, but I use the term resurgence because it implies that Indigenous knowledge has always been around and active. Furthermore, I use the term because I believe that the foundation of decolonization must be built around the resurgence of Indigenous knowledge. Otherwise, decolonization risks replicating non-Indigenous theories and practices. In this section, I will discuss five resurgence strategies that exist in the field of Indigenous governance: resistance, control, internationalization, ideational, and indigenization and how these strategies impact Indigenous governance. 
While decolonization and resurgence emerged as a component of Indigenous studies in the 1960s, resistance, as a form of resurgence, predates the emergence of Indigenous studies. The roots of the resistance can be extended to the moment of contact between Indigenous and European society (Obomsawim, 1993; Simpson, 2008c; Turpel \& Monture, 1990), and there have been numerous examples of resistance. Big Bear, a legendary Cree Chief, resisted signing the numbered treaties because he believed that the Canadian government would not fulfill the promises made in the treaties (Dempsey, 2006; McLeod, 2007; Venne 1997). While the Indian Act prevented overt political organizing between 1870 and 1951, the foundations of modern Indigenous political organizations originate in this time in resistance to the policies of colonization. In the United States, the American Indian Movement, while originally focused on urban Indigenous issues, expanded its scope to advocate Indigenous rights such as sovereignty and treaty (Baringer, 1997; Bonney, 1977; Johnson, 1996). Manuel \& Derrickson (2015) narrate the rise of resistance prior to the development of the 1982 Constitution. For them, resistance has been successful in forcing the Canadian government to alter the status quo paternalistic policy goals. During the Oka Crisis, Mohawk warriors resisted the apprehension of Mohawk lands for expanding a golf course (York \& Pindera, 1991). In the same year as the Oka Crisis, Elijah Harper stood with a single eagle feather against the Meech Lake Accord (Peach, 2011). Chief Theresa Spence initiated a hunger strike to compel the Federal government to address the ongoing colonial situation (Wotherspoon \& Hansen, 2013). Haudenosaunee people use their passports to travel internationally as a symbol of self-determination (Corntassel, 2012b). Finally, Idle No More, a recent grassroots political movement, openly resisted the Canadian Indigenous governance framework (Alfred, 2015; Palmater, 2015; Preston, 2013; McAdam, 2015). 
Resistance is resurgence because without resistance, the colonial project would have been successful in assimilating Indigenous peoples (Palmater, 2015). Resistance is also an act of Indigenous governance resurgence because these acts of resistance are built upon Indigenous governance theories and practices. One of the more visual aspects of Idle No More were the series of round dances that occurred in Canada and around the world. Round dances are held to honour the connection between people and the spirits (Jaine \& Halfe, 1989). For the Cree people spirituality is the highest form of Cree law (Wastesicoot, 2015). Spiritual law is central to the Canadian Indigenous relationship because the treaties were spiritual agreements between Indigenous and settler societies, and the Creator. Thus, ceremonies such as the round dance in grassroots political resistance like Idle No More, represents the resurgence of Indigenous governance theories and practices.

For others, resurgence will be achieved by gaining control of Indigenous affairs (Assembly of First Nations, 2005; Cardinal, 1969; Mercredi \& Turpel, 1993; Royal Commission on Aboriginal Peoples, 1996). In 1969, Cardinal argued that Indigenous people should have control of Indigenous affairs. Cairns (2000) pointed out that Cardinal's approach reinforced Euro-Canadian institutions through Citizen's plus recognition of Canadian citizenship and Treaty rights. Cairns (2000) made this conclusion because he looks too rigidly at the text of Cardinal's work instead of focusing on the implications of greater control. Cardinal's (1969) work was a response to the 1969 White Paper, which threatened the termination of Indigenous rights including governance. Thus, for Cardinal control was survival. Cardinal's work was foundational to the emergence of increased calls for Indigenous self-governance based on Indigenous knowledge (Belanger, 2014; Henderson, 2006). 
In the modern treaty process, control is autonomy (Baird, Davis, \& Madden, 2016). Indigenous control has shown to be more successful and empowering (Cooke \& McWhirter, 2011; Cornell \& Kalt, 1998; Cornell \& Taylor, 2000; Irlbacher-Fox, 2009; Jorgensen \& Taylor, 2000; Mitchell \& Bruhn, 2009; Niezen, 1993; Regan, 2010). Riley (2007) argued that control of Indigenous governance "protects tribal sovereignty and ensures their continued cultural and political existence" (p. 1049), but she also cautioned that more work needs to be done to develop the theories of Indigenous governance. My concern with control is that control does not guarantee the resurgence of Indigenous governance. For example, the creation of Nunavut had the greatest potential to incorporate Inuit knowledge, yet Inuit control of government and bureaucracy has not led to the greater protection of Inuit knowledge (Dacks, 2004; Henderson, 2008; Hicks, 2005; Timpson, 2006).

Some argue that resurgence can be achieved based on the principles of international law (Corntassel \& Primeau, 1995; Gunn, 2007; Henderson, 2008b). According to this approach, Indigenous people should use international legal principles of inherent rights and selfdetermination to further the resurgence of Indigenous governance. The use of the selfdetermination framework places Indigenous governance within the context of international law and fundamental human rights, which Canada created and uses to reinforce their sovereignty. Thus, the argument for Indigenous governance is not about recognition underneath the Canadian Constitution, but rather is it about the inherent right to self-determination under international law (Corntassel \& Primeau, 1995; Henderson, 2008b). The Canadian denial of these rights raises questions about the legitimacy of their claims of sovereignty and self-determination.

The internationalization of resurgence has elevated Indigenous rights and provided greater certainty. In 2000, the United Nations established a Permanent Forum on Indigenous 
issues, which is meant to provide "expert advice and recommendations on indigenous issues to the Council, as well as to programmes, funds and agencies of the United Nations" (United Nations, 2017, para. 3). The 2002 Convention on Biological Diversity recognized Indigenous consent as part of the United Nations framework of economic development (Manuel \& Derrickson, 2015). Several international human rights organizations have ruled that the Indian Act violated various international legal principles and treaties (Belanger, 2011; Manuel \& Derrickson, 2015; Palmater, 2011a). UNDRIP comprehensively recognizes a diverse set of Indigenous rights while simultaneously reinforcing international legal instruments (Henderson, 2008b).

The limitation of the internationalization of Indigenous resurgence is that the international political and legal order favors the nation state. For example, Article 2 (7) of the Charter of the United Nations states "nothing contained in the present Charter shall authorize the United Nations to intervene in matters which are essentially within the domestic jurisdiction of any state or shall require the Members to submit such matters to settlement under the present Charter" (United Nations, 2016). In other words, the international legal and political order favours the nation state by reinforcing territory boundaries that existed at the end of World War 1 (Zacher, 2001) and by largely excluding Indigenous people from participation in the new international order (Nichols, 2005). Furthermore, all levels of Canadian government have ignored the calls to implement UNDRIP. Finally, the Canadian government continues to ignore its own law and human rights standards regarding Indigenous people. For example, the First Nations Child and Family Caring Society has challenged the Canadian government in the Canadian Human Rights Tribunal to implement Jordan's Principle (Blackstock, 2012: Canadian Human Rights Tribunal, 2016). The internationalization of Indigenous rights has the potential to 
protect Indigenous rights, but without concrete actions by the state or a mechanism to compel states to action, internationalization is victim to the politics of distraction (Corntassel, 2012b). These distractions shift the energy of Indigenous people away from the resurgence of Indigenous knowledge to towards actions of the state, such as redress for olonization. Internationalization provides an international voice for Indigenous people in a state-centric institution.

There is an ideational aspect to the resurgence of Indigenous governance. According to this approach, resurgence would be best served by explicitly defining ideas of Indigenous governance. For Weaver (1984) defining Indian government would clarify the scope of Section 35 of the Constitution. The Royal Commission on Aboriginal People (1996) proposed the recognition of a third order of Canadian governance. Abigosis (2003) reviewed the traditional philosophies of her First Nation and developed a Constitution based on these philosophies. The National Centre for First Nations Governance (2008) has developed a set of Indigenous governance best practices designed to support Indigenous communities. The challenge of defining Indigenous governance is that providing a specific definition of Indigenous governance runs counter to Indigenous ontology (Battiste \& Henderson, 2000; Deloria Jr., 1997) and would conform to state-centric definitions of Indigenous knowledge (Corntassel, 2003). For example, both Napoleon (2007) and Borrows (2010) discuss the dynamic nature of Indigenous law. They characterize Indigenous law as a living tree that is a decentralized, spiritual, and legal order. A written constitutional model of Indigenous governance would shift the dynamic nature of Indigenous governance. Thus, there are grounds to be skeptical of the type of resurgence that is not critical of its role in recreating Euro-Canadian theories and practices governance. The ideational approach would clarify the scope of Indigenous governance but also recreate a constitutional model of governance. 
Finally, resurgence could be achieved by Indigenizing the Canadian Indigenous governance framework by combining Indigenous and Euro-Canadian governance theories and practices. Several authors (Jetté, 2002; Maaka \& Fleras, 2009; McGregor, 2014; Peel, 2011) argued that indigenizing policy making by including Indigenous knowledge would lead to better policy development. Several models of co-determination and mutual recognition have been proposed (Goulet \& Goulet, 2014; Pasternak, 2014; Sanderson, 2014). Indigenization from within will only work if the Canadian government is fully committed to the revision of its Indigenous governance framework. The political formation of Nunavut offered an experiment in this type of revision. However, an increasing amount of scholarship recognizes that Nunavut was not successful in integrating Indigenous knowledge (Henderson, 2008; Légaré, 2010; Timpson, 2006; White, 2006). Effectively, the creation of Nunavut resulted in a recreation of Euro-Canadian governance, including the creation of provincial style elections, bureaucratic hierarchy, and executive decision-making processes.

Indigenization can be achieved outside of the Canadian Indigenous governance framework. This type of Indigenization is the resurgence of Indigenous governance theories and practices through spirituality, the land, and language (Alexie, 2011; Alfred, 2005, 2009a; Corntassel, 2012b; Coulthard, 2014; Iseke-Barnes, 2008; Ladner, 2001b, 2014; Simpson, 2004, 2011; Ten Fingers, 2005; Wastesicoot, 2015). I believe that the resurgence of Indigenous governance theories and practices outside of the Canadian Indigenous governance framework is the future of Indigenous governance. I want to support this type of resurgence, which is why I have focused on exploring Nehinuw knowledge of Nehinuw governance. The other strategies of resurgence have tended to recreate Euro-Canadian governance theories and practices. At the same time, I recognize that focusing exclusively on the resurgence of Indigenous governance 
theories and practices naively overlooks the ongoing comprehensive and intergenerational impacts of colonization. In other words, while I believe that the resurgence of Indigenous governance is critical to the future of Indigenous society, how do acts of resurgence address the current socio-economic crisis impacting Indigenous peoples? To answer this question, I want to revisit the story of Big Bear.

Big Bear is a legendary Cree Chief that opposed signing treaty because he felt that the Canadian government did not intend to honour the treaties (Dempsey, 2006; Venne, 1997). Big Bear was recognized as a skilled leader in times of war and peace. Being skilled in times of conflict and peace was a considerable accomplishment for an individual in Cree society (Dempsey, 2006). Individuals were often only leaders in times of peace or conflict, not both (Mandelbaum, 1979). I am drawn to Cree leadership practice of having specific leaders in times of peace and conflict. Resurgence also needs many types of leaders, people that are dedicated to the resurgence of Indigenous knowledge and people that focus on the decolonization of the Canadian Indigenous governance framework. It is hard to be both because resurgence and decolonization takes considerable effort and involves different strategies. I have discussed these five resurgence strategies because we need to have multiple strategies to achieve resurgence and decolonization and these strategies underpin the foundation of this dissertation and my future work.

To prove that ninistotên (I understand) Indigenous governance, I reviewed the historical development of Indigenous governance. I see three areas of research in the field of Indigenous governance: resurgence research that explores Indigenous governance in Indigenous terms; decolonial research that challenges the Canadian Indigenous governance framework; and research that explores the Canadian Indigenous governance framework. Despite these three 
areas of research, much of the literature in the field has focused on the Canadian Indigenous governance framework. If Indigenous governance is to have a future, more resurgent and decolonial research is needed. This type of research is at the cutting edge of the field and expands our theoretical and practical understanding of Indigenous governance. This dissertation is designed to explore Indigenous governance in Indigenous terms, through the Nehinuw. In the next chapter, I explain how I conducted this research in a way that reflects this approach and honours and protects the knowledge of my people. 


\section{Chapter 3: Weechihitowin (Helping each other)}

\subsection{Weechihitowin: A Nehinuw Methodology}

When I began designing my dissertation, I reviewed the methodology literature. I became frustrated with mainstream methodologies because I wanted to use the methodology of my people and mainstream methodologies did not conform to my understanding of my people. I then started to focus explicitly on the Indigenous methodology literature. This literature was extremely helpful, but as I progressed into my research, I started to question Indigenous methodology literature. My people, the Nehinuw, are Indigenous, but we are also unique group of people with specific knowledge and protocols. Thus, I felt that it was necessary to go beyond the Indigenous methodology literature and focus specifically on the Nehinuw. Unfortunately, there is no source that specifically details the procedures and protocols of a Nehinuw methodology. To develop the methodology used in this dissertation, I had to be creative yet consistent with established protocols. I incorporated Nehinuw, Cree, and Indigenous literature, my experiences as a Nehinuw man, and community input. In this chapter, I will tell you the origin story of this methodology including a discussion on how this methodology emerged, what is this methodology, and a descriptive overview of each stage of this methodology.

As mentioned in the title of this chapter, I am calling the methodology used in this dissertation "Weechihitowin". Weechihitowin is a Nehinuw concept that refers to the interactive process of "helping or supporting each other" (Goulet \& Goulet, 2014, p. 61). For Goulet and Goulet, Weechihitowin is more than a concept; it is a pedagogy that focuses on developing teacher-student relationships. As a pedagogy, it is also not explicitly a research methodology. A research methodology "consists of the assumptions, postulates, rules, and methods - the blueprint or roadmap — that researchers employ to render their work open to analysis, critique, 
replication, repetition, and/or adaptation and to choose research methods" (Given, 2008, p. 516). To develop Weechihitowin as a methodology, I had to incorporate a wide variety of sources. I see Weechihitowin as a methodology because I am drawn to the idea of helping each other. Furthermore, the fundamental goal of this dissertation is to help preserve the knowledge of the Nehinuw, specifically knowledge of Nehinuw governance. Thus, Weechihitowin is the methodology I use in this dissertation, and, as a research methodology, Weechihitowin is a unique development of this dissertation but that still does not answer what is Weechihitowin.

To answer that question, I had to use an emerging design for this dissertation because I could not find a source that explicitly outlines the details and operation of a Nehinuw methodology. "Emergent design involves data collection and analysis procedures that can evolve over the course of a research project in response to what is learned in the earlier parts of the study" (Morgan, 2008, p. 246). I began with my understanding of my people. The Nehinuw have a rich oral tradition. I grew up listening to the stories of my people. I knew I would have to use a method that can capture oral knowledge. Sharing circles and interviews seemed to be the two most appropriate methods to explore the oral knowledge of my people. I reviewed sharing circle and interview literature and designed this dissertation to use these methods. However, as I progressed through the Ryerson University ethics review process, I realized I would need to do a much deeper critical analysis of my methodology and Indigenous methodology literature.

I realized that Indigenous ethics is not simply a commitment to the safety and confidentiality of my participants. Indigenous ethics is about utilizing Indigenous research protocols and fostering meaningful community engagement throughout your research (Castellano, 2004). This dissertation followed established academic protocols for research in Indigenous communities, including submitting my research proposal to review by the REB and 
creating a dissertation that is owned by the Indigenous community (Kovach, 2009; University of Victoria, 2003, Wilson, 2007; Wilson 2008). In addition to these established academic protocols, this dissertation has been designed following the guidelines outlined in Chapter 9 of the TriCouncil policy on research with the First Nations, Inuit and Métis Peoples of Canada (CIHR, NSERC, \& SSHRC, 2014) and as per a negotiated research agreement with research communities. These negotiated research agreements ensure that the knowledge discussed in this dissertation will be shared and utilized by the Nehinuw people and communities as they see fit, through physical copies and summaries of this dissertation and in a community engagement event upon completion of this dissertation. Furthermore, none of the knowledge in this dissertation was gathered according to any sacred protocol which forbade me from sharing that knowledge. The Glossary for Nehinuw Governance Theories and Practices will be shared in digital format, so it can be edited and used for educational purposes.

I was particularly challenged by the concepts of community engagement and collaboration. As stated in the Tri-Council Policy Statement: Ethical Conduct for Research Involving Humans,

In 2001, Canada's three Federal research agencies, Canadian Institutes of Health Research (CIHR), Natural Sciences and Engineering Research Council of Canada (NSERC), and Social Sciences and Humanities Research Council of Canada (SSHRC) jointly created the Interagency Advisory Panel on Research Ethics (PRE or the Panel) as part of a collaborative effort to promote the ethical conduct of research involving human participants. (CIHR, NSERC, \& SSHRC, 2017, para. 1) This policy statement is the central document that provides ethical guidelines for research involving humans. Chapter 9 of this document outlines ethical principles for research involving 
First Nations, Inuit, and Métis people (CIHR, NSERC, \& SSHRC, 2014). One central component of Chapter 9 details how to engage with the Aboriginal community. According to this policy:

Community engagement...can take varied forms. In geographic and organizational communities that have local governments or formal leadership, engagement prior to the recruitment of participants would normally take the form of review and approval of a research proposal by a designated body. In less structured situations (e.g., a community of interest), a key consideration for researchers, prospective participants and REBs is determining the nature and extent of community engagement required. In some situations, if the REB is satisfied that participants are not identified with a community or that the welfare of relevant communities is not affected, the REB may waive the requirement of a community engagement plan. In these cases, consent of individuals is sufficient to participate. (CIHR, NSERC, \& SSHRC, 2014, p. 116)

In other words, this section on community engagement outlines the procedures to ensure that communities or individuals have consented to the project. While these community engagement procedures are critical, I do not feel that these procedures create meaningful community engagement. Meaningful engagement is more than achieving consent. To achieve meaningful community engagement, the researcher must be open to changing their project not just to review the project. Meaningful community engagement requires collaboration, which brings me to my second point.

Chapter 9 does provide some guidance on collaboration. "Collaborative research is generally understood to involve respectful relationships among colleagues, each bringing distinct 
expertise to a project" (CIHR, NSERC, \& SSHRC, 2014, p.128). However, I do not feel that Chapter 9 goes far enough to create meaningful collaboration. How can the researcher respectfully collaborate if they bring their distinct expertise to a project? To collaborate in a meaningful way, the researcher must be open to other perspectives on their research, which could include shifting focus or methodology. In other words, using an emerging research design has been critical to develop meaningful research and relationships with Indigenous communities and people. The emerging design helped make two major changes to my dissertation. First, community contacts and participants suggested that I not use sharing circles to gather knowledge. I altered this dissertation to focus on individual interviews. However, I did conduct a series of community engagement events to share results with the involved communities. Second, I moved away from mainstream methods of data analysis and developed a unique method of analysis based on the Nehinuw concept of Nistotên (to understand). There is no reference to Nehinuw methods of analysis in the literature. I combined personal reflection, trips to my home territory, participant input, and Lavallée's (2009) work to develop this method. I will describe the theory and practice of Nistotên in detail further on in this chapter. I would like to explore methods of developing meaningful relationships in a future research project.

While using an emerging design was necessary to support the development of the Weechihitowin methodology, Nehinuw, Cree, and Indigenous research principles are the basis of the Weechihitowin methodology. I will now discuss the theoretical contributions that Nehinuw, Cree, and Indigenous literature have made to the Weechihitowin methodology, and how I have operationalized this methodology. To begin, there are several valuable sources on Nehinuw research principles. Goulet (1986) is perhaps one of the first Nehinuw scholars that attempted to validate the oral traditions of the Nehinuw people in academic literature. He has been extremely 
influential in the development of this dissertation and many of his concepts are used throughout this dissertation. Goulet's work discusses various aspects of the Nehinuw worldview, such as the Nehinuw concept of understanding, the challenge of translating ideas, and Nehinuw concepts of teaching (Goulet \& Goulet, 2014). One of the primary concepts that will be used is the concept of Weechihitowin, which translates as "helping or supporting each other" (Goulet \& Goulet, 2014, p. 61). The idea of helping each other is the primary justification for my interest in Nehinuw governance and I use Weechihitowin as a methodology. How I have gathered knowledge is another key component of this dissertation. I will be using the Nehinuw narrative framework of Weetumatowin, which focuses on the sharing of information (Goulet \& Goulet, 2014). I will expand upon the procedures and protocols of Weetumatowin in section 3.2 further on in this chapter. Finally, how I interpret the knowledge collected during this dissertation is also a key component of the Weechihitowin methodology. I am utilizing the Nehinuw concept of Nistotên to interpret the knowledge collected during this dissertation, which includes a process of knowledge sharing. I will expand on Nistotên in section 3.3 further on in this chapter.

In addition to Goulet, the Wilsons are a family of Nehinuw scholars. Leonard Wilson (1989) utilized his experience teaching Cree children in Northern Manitoba to direct his dissertation. He uses the term "Opasquiak" in specific reference to the community setting. Furthermore, he utilizes the Nehinuw language throughout his dissertation and collected data in the Nehinuw language. Alex Wilson (2007) bases her dissertation on Nehinuw research principles. She uses the terms "Nehinow" and "Inniniwuk" to refer to Cree people and she stresses the importance of community engagement. For example, she states that there is "both an ethical and moral obligation to respect, prepare and attend to the voices of our people" (Wilson, 2007, p. 31). Shawn Wilson $(2001,2008)$ provides many important observations for the 
Nehinuw methodology, such as the importance of relationships and collective ownership of Indigenous knowledge. He provides valuable insights into the goals of Indigenous research. For example, he argues that the primary goal of Indigenous research is to move from "an 'Indigenous perspective in research' to 'researching from an Indigenous paradigm'” (Wilson, 2001, p. 175). I agree with these perspectives and I see "researching from an Indigenous paradigm" as requiring a commitment to a specific Indigenous paradigm not just the use of best practices in Indigenous methodology literature. For this reason, I have designed this dissertation to focus explicitly on the Nehinuw worldview.

There are a few issues with the direct applicability of the above noted work. First, despite the theoretical value of their work, they do not specifically define the protocols and practices of a Nehinuw methodology. Second, neither of these authors explicitly identify as Nehinuw. However, this issue is due to the slight variance of terms used in the literature. Modern Cree language texts use standard roman orthography (Okimasis, 2004; Ratt, 2016), and neither I nor the Wilsons use standard Roman orthography. Thus, the Wilsons and myself are Nehinuw despite different spellings. For example, Alex Wilson (2007) uses "Nehinow", which is an alternative spelling of Nehinuw. Third, they also incorporate broad Indigenous perspectives in their work. For example, Shawn Wilson's (2008) work is a comparative and international analysis of Indigenous research principles. In other words, to feel confident that I was following a Nehinuw methodology, I felt that it was necessary to also consider the broader Cree methodology literature.

In addition to this Nehinuw literature, there are many Cree methodology principles that I have incorporated into the Weechihitowin methodology. Steinhauer-Hill (2008) described the purpose of ceremony, the role of Elders, the use of dreams to interpret knowledge, and provided 
a detailed operationalization of Cree analysis. Kovach (2009) comprehensively discussed the theory of Indigenous methodologies, including detailed protocols for conducting Indigenous research. Wheeler (2010) looked at the oral traditions of the Nêhiyawak people including a valuable discussion on the citation methods of the Nêhiyawak people. Michell (2012) discussed the pedagogical value of incorporative Woodland Cree concepts into western science.

The Indigenous methodology literature has also contributed research principles that are used in the Weechihitowin methodology. Grenier (1998) provided a comprehensive description of Indigenous knowledge designed to improve research on Indigenous territories. Absolon and Willett (2004) discussed the importance of self-location. Lavallée (2009) effectively bridged the gap between Indigenous and western methodologies by incorporating Indigenous knowledge into her research. Chilisa (2012) discussed the theoretical differences between Indigenous and mainstream research methods such as the unique nature of the Indigenous interview. Several scholars have argued that Indigenous knowledge is best explored through an Indigenous methodology (Castellano, 2004; Daes, 1994; Gaudry, 2011; Ringley, 1999; Scheurich \& Young, 1997; Smith, 2012; Ten Fingers, 2005). Castellano (2004) and Ermine, Sinclair, and Jeffery, (2004) argued that Indigenous research should strive to benefit Indigenous communities. Finally, the principles of ownership, control, access and possession (OCAP) were developed to empower Indigenous communities to reclaim Indigenous knowledge (First Nations Centre, 2007; Laenui, 2000). Based on this literature, Weechihitowin has four foundational principles including support and protection of Indigenous knowledge, collection of knowledge using an Indigenous language and methods, interpretation of knowledge based on an Indigenous worldview, and partnership and collaboration with specific Indigenous communities. 
I have used Nehinuw, Cree and Indigenous research principles as the basis for the Weechihitowin methodology. At a practical level, Weechihitowin progressed through three stages. The first stage of developing a dissertation involves a literature review to establish the need for a study (Dunleavy, 2003). As Goulet and Goulet (2014) discuss, even though collectivism is a central component of Nehinuw thought, the individual has an important role in the Nehinuw worldview. Thus, if this dissertation is to fulfill the role of helping or supporting the Nehinuw, there also must be a stage of self-learning. Kiskinaumasowin refers to "the act of teaching oneself" (Goulet \& Goulet, 2014, p. 65). I see the literature review as a process in which I must teach myself about governance and I have titled chapter 2 around this concept.

The second stage involves the collection of knowledge. Like other Indigenous (Battiste \& Henderson, 2000; Chilisa, 2012) and Cree peoples (Kovach, 2009; Stevenson, 2000; Wheeler, 2010), oral history is also an integral part of the Nehinuw worldview (Goulet \& Goulet, 2014; Wilson, 2008). The primary knowledge gathered for this dissertation was oral histories based on the lived experiences of my participants. In reflection upon this literature and discussions with Nehinuw Elders, I feel that oral history does not do justice to the rich oral tradition of the Cree people. For example, Wheeler (2010) discusses the use of oral footnotes by Cree people. Goulet and Goulet (2014) discuss the diversity of narrative frameworks within the Nehinuw worldview. Therefore, I felt it was necessary to focus on a specific Nehinuw narrative framework and use specific protocols associated with that framework. Thus, I have focused on Weetumatowin. While I will expand on Weetumatowin in section 3.2, Weetumatowin is a Nehinuw narrative framework that focuses on the sharing of information.

Finally, the Nehinuw learn through experience. Kolb (1984) refers to this type of learning as "experiential learning" (p. 3). The challenge for this dissertation was that I proposed 
to explore the abstract concept of governance. Thus, the question I had was how can I experience an abstract concept of governance? To accommodate for experiential learning, this dissertation focused on the lived experiences of my participants and documented how my understanding of the central topic evolved throughout the dissertation. This documentation of governance was based around the Nehinuw concept of Nistotên. While I will expand on this method in section 3.3, Nistotên is a Nehinuw framework of analysis that combines on oral history and experiential learning.

\subsection{Weetumatowin: Nehinuw Knowledge Gathering and Research Design}

The Nehinuw people share stories through three basic frameworks and 15 different subforms. Weetumatowin is a framework that focuses on the sharing of information.

In the case of Weetumatowin the frontal stem, weetu-, means sharing or disclosing information and is an ancient form of newsgathering. For greater emphasis, the semantic morphological structure and meaning of the medial stem -ato denotes interactivity. Weetumatowin is therefore the dialogic sharing of information or the everyday news among individuals, people, and various self-groups or groups. (Goulet \& Goulet, 2014, p. 61)

Since the primary focus of my dissertation is to share knowledge on Nehinuw governance, Weetumatowin is the most appropriate Nehinuw narrative framework. I have used Weetumatowin as the primary method for gathering knowledge in this dissertation. The challenge is that Goulet and Goulet (2014) only discuss Weetumatowin as a theoretical concept; thus, I have expanded Weetumatowin to include several protocols identified in Indigenous literature. In this section, I will elaborate on the theoretical and practical foundation of Weetumatowin including a discussion on how storytelling, relationships, ceremony, 
confidentiality, and ownership are central to this method. I will end by discussing the practical application of Weetumatowin in the field.

Weetumatowin is a narrative framework that focuses on the sharing of oral knowledge (Goulet \& Goulet, 2014). It was critical that I used an oral method to explore the rich oral traditions of the Cree people (Absolon, 2011; Steinhauer-Hill, 2008; Wheeler, 2010). The qualitative research paradigm has numerous methods that focus on oral knowledge, such as the interview method (Rubin, \& Rubin, 2012). However, the standard qualitative interview cannot account for the oral traditions of Indigenous people. Chilisa (2012) argues that the standard interview method creates "asymmetrical relations between the interviewer and the interviewee" (p.203). Similarly, Kovach (2009) contends that the rigidness of the standard interview method is not appropriate for exploring Indigneous oral knowledge. Thus, I wanted to base this dissertation on an Indigenous method of inquiry. Based on the numerous narrative frameworks that Goulet and Goulet (2014) discussed, I felt that Weetumatowin was the most relevant method for approach desired in this dissertation since Weetumatowin focuses on the sharing of information between people.

I also needed to make room for building relationships. Many Cree scholars (McLeod, 2007; Steinhauer-Hill, 2008; Wheeler, 2010; Wilson, 2008) have noted the importance of relationships within the Cree worldview. Being Nehinuw and from the territory, I already knew many of the participants. Nevertheless, I contacted each participant with the utmost respect, asking them for their knowledge on this topic and placing myself as the learner (Wilson, 2008), and asking if they would be willing to be a participant in this dissertation. Central to this initial discussion was clearly stating that this dissertation is fundamentally about the protection of our knowledge, as Nehinuw people, and that it is for involved communities. I do not view 
Weetumatowin as an opportunity to extract knowledge from my participants, which is a part of the standard interview method (Rubin \& Rubin, 2012), rather developing these lifelong relationships allows me to become part of the living body of knowledge represented by this dissertation and owned by the Nehinuw people. Furthermore, I will continue to maintain personal relationships with all my participants after this dissertation.

In addition to maintaining relationships, I wanted to be critical about my participant selection criterion. I began this dissertation thinking that I would only approach Elders since Elders are sacred experts central to Indigenous knowledge (Lavallée, 2009; McLeod, 2005; Stiegelbauer, 1996; Steinhauer-Hill, 2008; Wheeler, 2010). However, I decided to expand my participant eligibility criteria to include Elders and experts. I wanted to recognize that not all Elders refer to themselves as Elders even if they are recognized by their community as an Elder. In past research projects, I had some difficulty working with the Elder criteria. In one instance, I worked with a community to identify and contact Elders. Despite community recognition, several of the participants claimed not to be an Elder. For that project, I had to decide if I could include community recognized Elders regardless of their personal identification. I wanted to avoid this dilemma in this dissertation, so I decided to select participants based on community input. Furthermore, I also wanted to empower the community to select participants for this dissertation to meet my goal of creating meaningful collaboration under Chapter 9 of the TriCouncil policy statement. Some of the participants were Elders but not all recognized themselves to be an Elder.

Ceremony was an important aspect of Weetumatowin. Ceremony is a critical component of Indigenous worldviews (Stonechild, 2016; Wastesicoot, 2015) and research (Wilson, 2008). Lavallée (2009) incorporated ceremony into her research by offering traditional medicines as a 
form of consent. I agree with this approach, and I incorporated the gift giving ceremony into Weetumatowin by offering Amisko-wihkasosiy (Mint) and Wekes (Rat Root) as part of my consent process. Stonechild (2016) discusses how gift giving is central to many Indigenous ceremonies. Goulet and Goulet (2014) do not mention if gifts are specifically given during Weetumatowin; but, if Weetumatowin is a framework for the sharing of information, I believe the exchange of gifts and respect is central to Weetumatowin, which is why I included this ceremony in Weetumatowin.

In terms of confidentiality, I agree that the standard qualitative interview has a different view of confidentiality and creates a power relationship between researcher and participant. However, I also recognize that Indigenous research has a different standard of confidentiality, often sources wish to be named (Chilisa, 2012). I approached confidentiality by asking participants if they wished to be named as a source, both verbally and in writing. Since several participants desired to remain confidential, I referred to all participants as respondents and used a random numerical system to provide some distinctions between participants. For the participants that agreed to be recognized, I have acknowledged their names in the beginning of this dissertation.

Weetumatowin should also follow established principles of ownership, control, access and possession (First Nations Centre, 2007). I have recognized these principles by negotiating research agreements with communities (see Appendix B) and provided final copies of this research that may be edited by the community. Furthermore, I recognized the importance of meaningful community engagement (Wilson 2007) by actively discussing this dissertation with community leadership and participants. Finally, in addition to meeting the requirements of 
Indigenous research, this dissertation has also been approved by the Ryerson University Research Ethics Board.

The practical application of Weetumatowin began prior to ethics approval. I began by contacting several researchers, who had recently worked in the area, for their input on research in this territory. These contacts provided three inputs for this dissertation. First, Dr. Graham Strickert, who had worked on a major water security study in the Cumberland House region for the University of Saskatchewan, discussed the success he had selecting participants with the snowball recruitment method. Snowball recruitment allows the researcher to select participants based on a list of participants identified by the community (Atkinson \& Flint, 2004). As outsiders to the community, he felt this approach empowered the community to select the appropriate Elders and experts (G. Strickert, personal communication, April 25, 2014). Second, Dr. Strickert provided valuable insights on community engagement. His community engagement strategy included personal meetings with participants to discuss the research project and letters of support sent to community leadership (G. Strickert, personal communication, April 25, 2014). Dr. Strickert did not mention any major challenges or difficulties faced when engaging the communities. This project involved one community, Cumberland House. I followed these procedures to initiate contact with the communities. Third, Ms. Mika Carriere, who had worked on a Woodland Caribou study in the area, shared her experiences working with Elders in the area. She noted that her project had difficulties gathering data in group situations with Elders. Elders were much more willing to share knowledge in a focused individual interview (M. Carriere, personal communication, May 12, 2014). I used this input to revisit the methods used in this area, focusing on the interview. 
After these consultations, I began engaging Nehinuw communities to secure research agreements. I contacted four Nehinuw communities, Cumberland House, Saskatchewan; Red Earth, Saskatchewan; Shoal Lake, Saskatchewan; and Opaskwayak Cree Nation, Manitoba. I initiated contact by phoning local band and community offices to ask local administrators what the best avenue would be to obtain approval and input on my dissertation. These administrators suggested that I facsimile my research proposal for review at a community leadership meeting. My proposal indicated I was a student from Cumberland House interested in doing research in the area and that I would like to ask local leadership for approval to proceed with my dissertation. I followed instructions and waited one week before I made a follow-up contact to see what had been done with my proposal. Within the first week, I managed to get one letter of support and one other community was ready to draft the letter, but they preferred to meet in person before any agreements were finalized.

After contacting all four Nehinuw communities, I was only able to negotiate research agreements with Cumberland House and Opaskwayak Cree Nation. The other communities were interested in this dissertation, but after several attempts over four months I was not able to obtain the appropriate consent to proceed with my research in these communities. I decided to proceed with the dissertation based on participation of two Nehinuw communities. This is justifiable since Makokis (2001) completed her dissertation with input from only one Nêhiyaw community. For each community, I negotiated a research agreement. These agreements included consent to conduct this research, support to contact individuals in the community, and support to conduct one community engagement event. While I ended up securing fewer research agreements than the four originally planned, I ended up contacting more individuals in these communities than 
was originally proposed. In future research on Nehinuw governance, I would like to work with all Nehinuw communities.

Once community research agreements were secured, I submitted my ethics proposal to the Ryerson University Research Ethics Board (REB). My application was approved August 6, 2014. To maintain the confidentiality of participants, all information collected during this dissertation was kept in a secured location. All digital files were saved in different parts of my computer and locked with a password only known by myself. Paper files were kept in a locked file cabinet. Files were not saved under participants' names but as a pseudonym. Any personal data I obtained was saved in a different file. If I used a quotation from a participant, I only used the appropriate pseudonym. I have not used any quotations from participants with language that may link that quotation to the participant. All stories used in this dissertation will be displayed using the title "Respondent". The title of each respondent will consistently recognize individual contributions by applying a numerical indicator to the respondent. For example, "Respondent 1" refers to a specific participant. If a participant preferred to be recognized for their participation, I recognized their participation in the acknowledgement section. As Chilisa (2012) discusses, often Indigenous participants prefer to be recognized for their contribution to the project.

After ethics approval, I began contacting potential interview candidates based on input from the community. My goal was to work with the communities to select Elders and experts that would have considerable knowledge of Nehinuw governance. I selected participants using a snowball selection process with input from the community and participants. I used this selection method based on the advice of researchers, whom conducted research in this area, and past research in the area (Morrison, 2012). Furthermore, Chilisa (2012) contends that a postcolonial Indigenous paradigm is based on "relational accountability, respectful representation, reciprocial 
appropriation, and rights and responsibilities" (p.174). I feel the snowball method achieves these requirements by empowering the community to select participants. I asked community leadership to identify people who would be a valuable resource for my dissertation. I then proceeded to contact these people by telephone, not all people contacted were able or willing to participate. In these initial conversations, I briefly explained my dissertation and asked if they were interested in being a participant. If they were willing to be a participant, I indicated that Weetumatowin would take one hour and thirty minutes or less at a location of their choosing. We then proceeded to organize the date and location for Weetumatowin.

At the end of Weetumatowin, I asked participants to identify other participants that would be a beneficial source for this dissertation. This snowball method led to the selection of 12 Nehinuw governance Elders and experts, six from each community. I conducted a one-hour interview with each participant. I maintained communication with the participants throughout and conducted seven follow-up conversations that lasted between thirty minutes and one hour.

My approach is consistent with other Indigenous research carried out in the field (Alexie, 2011, Hansen, 2012; Makokis, 2001; Simpson, 1999, Sinclair, 2007; Steinhauer-Hill, 2008; Wastesicoot, 2015: Wilson, 2007). I discuss the validity of this approach in more detail in section 3.4 further on in this chapter. However, I would like to note that Indigenous validity principles are held to different standards focusing more on quality, community engagement, and long-term relationships. While I did create a restriction for all participants to be over 18 years of age, the community and participants did not identify any Elders or experts that were under the age of 18. Additionally, fluency in the Nehinuw language was not a requirement. Finally, there were no qualifications for experience in formal governance roles. 
In the field, Weetumatowin is like semi-structured interviews, which focused on open discussion, oral history, and sharing. I began Weetumatowin by revisiting the intentions of my dissertation. Following this, I reviewed the consent form (see Appendix C). I stressed the volunteer nature of Weetumatowin and that if they were uncomfortable they could at any time stop Weetumatowin. I asked if the participant wished to keep their identity confidential or if they wanted their name to appear in the print version of the written materials. I then offered traditional medicine as a form of consent based on Lavallée's (2009) approach to consent in Indigenous research. As Lavallée outlines, it is appropriate in the Indigenous context to obtain consent through a combination of traditional medicine bundles and/or written consent forms. I felt that this gift giving procedure was also consistent with the Nehinuw worldview. I prepared these traditional medicine bundles with the support of Ms. Michela Carrière prior to the interviews. The Ryerson Aboriginal Education Council provided funding for the medicine bundles. These traditional Nehinuw medicine bundles included a combination of traditional Nehinuw medicines including Amisko-wihkasosiy (Mint) and Wekes (Rat root). I provided a combination of consent options for the participant including consent form and traditional medicine, only consent form, and only traditional medicine. Following this step, I asked the participant if I could audio record Weetumatowin. I explained that the digital recording would only be used to support this dissertation. All participants agreed to have Weetumatowin digitally recorded. I also explained that I would be taking detailed notes during Weetumatowin. None of the participants had any issues with these procedures.

Weetumatowin began after going through the entire consent process. To answer the main research question of this dissertation, what does Nehinuw knowledge teach us about Nehinuw governance, I developed a set of guiding questions including: 
1) What is Nehinuw governance?

2) How does Nehinuw governance incorporate Nehinuw knowledge?

3) Who were and are the key actors of the Nehinuw governance and has that changed?

4) What is the jurisdiction of Nehinuw governance and has that changed?

5) How does the contemporary governance process utilize traditional values and principles of governance?

6) How can Canadian governance become more inclusive of Nehinuw governance?

7) How do other Indigenous organizations incorporate Indigenous knowledge?

8) What aspects of Nehinuw governance should key stakeholders be aware of when working with Nehinuw communities?

These questions became the basis for a comprehensive list of questions identified in Appendix D. Originally, I envisioned only asking these questions, but it became clear during my research that I would only use these questions as guiding questions. For example, participants often answered multiple questions. Furthermore, I felt that several of the questions were overly academic and confusing when talking with Elders. For example, I had a question that aims to talk about the Nehinuw policy process. The policy process is an advanced concept that would require specific experience in Euro-Canadian governance or post-secondary education in political science or public administration. Since I wanted to gain a deeper understanding of Nehinuw knowledge, I began to use the governance concept since it has a broad definition. Additionally, I integrated any learned Nehinuw concepts into the guiding questions. For example, the first question of this dissertation is what is Nehinuw governance? I realized in my first interview, and confirmed in subsequent interviews, that there is no specific word for governance. Participants had to translate that word into the Nehinuw worldview. The first 
participant used the concept of Ohcinêwin (law of the land) to talk about governance. In the following interview, I asked if Ohcinêwin was governance. While the subsequent participants agreed that Ohcinêwin is a part of Nehinuw governance, each participant would expand upon the idea of Nehinuw governance based on their lived experiences.

During Weetumatowin, I focused on the process of listening by balancing questions, listening and reflection (Seidman, 2013). I used the research questions to guide Weetumatowin around my topic, like the responsive approach used by Rubin and Rubin (2012). To support my listening and reflection, I simultaneously took detailed notes identifying questions, potential themes, and ideas. At the end of Weetumatowin, I offered all participants a small honorarium of twenty dollars for their participation. Offering a small honorarium is consistent with established local and academic guidelines that ensure that participation is voluntary (Fowler, 2009). The Ryerson Aboriginal Education Council provided the funding for the honorariums. I also thanked the participant for their time, discussed the timeline of my research, and asked for input on additional participants. I gave all participants my contact information and asked them to refer my contact information to any individuals they felt would be interested in contributing to this dissertation. All data was collected using the protocols of Weetumatowin outlined above. Weetumatowin was conducted in English. Weetumatowin took place between August and October 2014.

\subsection{Nistotên: Nehinuw Analysis}

According to Goulet and Goulet (2014), the Nehinuw verb Nistotên (to understand), is a key verb in the language. When teaching someone, one would ask, Kinistotên? (Do you understand?) Even after the knowledge has been passed on, a Nehinuw person would not say Ninistotên (I understand) until they truly understand that specific knowledge (K. Goulet, 
Personal Communication, December 16, 2014). Understanding is central to the transmission of knowledge in the Nehinuw worldview. I remember many times being taught a skill and then asked Kinistotên? Often, I would have to prove that I could successfully complete the skill before I could claim to understand.

The process of Nistotên is like the process of qualitative analysis. Grbich (2013) describes qualitative analysis as "your theoretical interpretation of your analyzed data, presented for the reader to assess" (1. 88). Creswell $(2009,2013)$ separates data analysis into a series of stages emphasizing elements of organization, interpretation, coding, discussing, and understanding. In other words, within the western research paradigm, analysis is the interpretation and understanding of your data. I am required to prove that I understand the data I have collected. However, as I learn more about Indigenous research paradigms, I have realized that an Indigneous framework of analysis goes beyond the requirements of standard qualitative analysis. I am specifically interested in the idea of "understanding". I feel that the Nehinuw process of Nistotên, the process of understanding, fulfills and goes beyond the requirements of standard qualitative analysis. However, there is a lack of literature that discusses the operationalization of Indigenous analysis. This section will discuss the theoretical and practical basis of Nistotên, which is the unique method of analysis I have developed for this dissertation based on my experiences and Nehinuw, Cree and Indigenous literature.

Steinhauer-Hill (2008) argues that to complete Indigenous analysis, "we must honour the thinking and context of Indigenous intelligence" (p. 91). For her, Indigenous analysis, which is based on Elder Lionel Kinunwa's framework, contains five steps including saturation, incubation, analysis, illumination, and adaptation. However, it is unclear if these five steps are the basis of her analysis because she uses a different set of five stages of analysis including 
thematic analysis, dreaming analysis, articulating the dream, Indigenous analysis, and language and learning. Regardless of names of the steps, Steinhauer-Hill argues that Indigenous analysis is a "relational synthesis" (p. 132) meaning that analysis involves numerous layers of circular reflection. I do not utilize Steinhauer-Hill's work as the only source on analysis because she writes from a Nêhiyaw perspective. Furthermore, I do not fully understand how she operationalizes Indigenous analysis, and I only discovered her work after I had completed the analysis for this dissertation. One interesting component of her research that I would like to use in future research is her use of dream analysis. I have read of the importance of dreams for the Cree people (Cardinal \& Hildebrandt, 2000; Stonechild, 2016; Wastesicoot, 2015; Wheeler, 2010) and heard many Nehinuw people discuss dreams as a source of knowledge. There were moments during this dissertation when I did dream about this dissertation. For example, during my trip into the land, I was only able to understand the connection between Nistotên and analysis while daydreaming on a snowmobile.

Lavallée overcomes the limitations of "standardized" qualitative analysis by infusing the Indigenous worldview throughout her work. She has thanked participants in an Indigenous language; presented participants with research gifts; used Indigenous research methods; utilized traditional teachings such as the medicine wheel (2008); incorporated an Indigenous method of analysis such as Anishinaabe symbol-based reflection (2007); focused on Indigenous storytelling (2008); followed community-based protocols (Lavallée \& Howard, 2011); and retold the collective story through themes identified with the qualitative analysis computer program NVivo (Lavallée, 2009). Lavallée's methods of analysis have been an inspiration for this dissertation, and I have incorporated many of the elements she identifies throughout this dissertation. For example, I have implemented Lavallée's gift-giving protocol as part of my consent process. 
When I began to design this dissertation, I planned to follow Lavallée's (2009) analysis technique. She used NVivo to bridge Indigenous and Western research by inputting transcribed text into NVivo, identifying themes within the data, and using these themes to tell the collective story of her data. She explained to me that NVivo helped her organize her research and develop a deep understanding of the stories. I was drawn to the idea of using a tool that could help me develop a deeper understanding of my dissertation. NVivo is a computer program designed "to help you organize, analyze and find insights in unstructured, or qualitative data like interviews" (QSR International, 2015, para. 4). NVivo can be used to do several qualitative data analysis procedures, such as content and thematic analysis (Grbich, 2013). I envisioned using NVivo to analyze the themes of the dissertation, and I took several training classes to expand my skills with the program. However, as I began to analyze the knowledge that I gathered during Weetumatowin, I started to feel that NVivo was inconsistent with Nehinuw research principles. Furthermore, I also questioned using Lavallée's (2009) technique since my dissertation is based on the Nehinuw worldview and Lavallée's approach is based on Algonquin, Cree, and Ojibwe teachings.

Like Lavallée (2009), I input my interview transcripts into NVivo and used the program to identify themes. However, my method of analysis differs from Lavallée because I do not attempt to retell the collective story. NVivo helped me Nistotên (to understand) Nehinuw governance by providing an effective tool to organize my thoughts and see connections between participants. For example, following the transcription of the interviews, I inserted the transcripts into NVivo 10 and began to code the interviews for key themes. In this stage, I compared my notes with the transcripts and inserted any comments, themes or ideas into NVivo. Many of the themes are structured around verbatim concepts identified by the participant. In many cases, I 
highlighted large sections of text, paragraphs or sentences that were framed around specific concepts. Only when the Nehinuw language was used would I highlight specific words. During the process of Nistotên, I would frequently return to the interviews and NVivo to review the themes and reflect upon the knowledge in the interviews. Since I am not fluent in Nehinuw, I began using English words to organize the themes in NVivo. As I progressed further into Nistotên, I began to rely on the Nehinuw concepts.

As mentioned previously, the Nehinuw verb Nistotên is a key verb for the Nehinuw people, and I felt that to be able Nistotên meets the requirements of quantitative and qualitative analysis. I approached Dr. Lynn Lavallée with this observation, and she posed a challenging question, "how will you prove Nistotên?" Steinhauer-Hill (2008) underwent the same logical challenge; except for her the question posed was "what is Cree truth?" To answer this challenging question, Lavallée advised me to return to my home territory to reflect on the concept of Nistotên and how to prove Nistotên.

I returned home in the winter of 2014 to reflect on the concept of Nistotên. One day, my father told me he wanted to take me out to a special and isolated place on our territory. The next day we bundled up and prepared for the 70 kilometre trek. My father wanted to go to the Mossy River, where my grandfather once had a cabin in the late 1950s. It took us most of the day to reach the Mossy River. When we arrived at the Mossy, we made a fire and my father told me about the first time he came to this place.

Years ago, my grandfather told my father, in the Nehinuw language, how to get to the Mossy River. At the end of the story, my grandfather asked my father, Kinistotên? (Do you understand?) My dad could not answer; he had to go out and experience the story before he could answer that question. He went out on the land, followed the instructions of my 
grandfather, and hunted at the Mossy River. When my father returned to my grandfather, my father said, Ninistotên. He now understood.

After telling me this story, we packed up our goods and began the journey back home. The journey back was a two-hour snowmobile ride. The Mossy River is a very special, isolated and beautiful place on my family's traditional territory. I have many memories of the Mossy River, and on the drive back I relaxed and let my mind wander. At some point on the return journey, I began to think of the story my father told me about his first journey to the Mossy River. I realized that this story contained three elements that my father used to prove Nistotên. The first stage of Nistotên was experience. Before my father could say that he understood, he had to go out and experience the land. My father's experience represents the transmission of knowledge in the Nehinuw worldview. In the Nehinuw worldview, one learns by experience and oral history. These two factors combine to form Indigenous knowledge. My grandfather shared knowledge, in the form of a story on how to get from A to B. In this case, it was straightforward for my father to experience this knowledge. He could physically go from A to B. In my case, I am proposing to explore the abstract concept of governance; therefore, I cannot physically go to governance. However, I can document how my understanding of governance shifted during this dissertation. This personal journey is like the physical journey that my father took to go to this place on our traditional territory. For this experience stage of analysis, I will discuss how my understanding of governance has changed throughout the research process. This approach is like classical phenomenological analysis, which involves "reflecting on what you have gained through reading and re-reading and through journaling your thoughts, including any questions and responses" (Grbich, 2013, 1. 2281). However, I will Indigenize the classical 
phenomenological analysis by going beyond this journaling approach. I feel that to Nistotên requires several stages of reflection.

The second component of Nistotên, which I call sharing, occurred after my father went out on to the land. He followed the directions, was able to get exactly to the spot his father described, and when he returned he could say that he physically travelled to the spot. $\mathrm{He}$ reinforced the experience with a physical journey from A to B. In my case, I see this sharing occurring in a similar way, as I will return to my participants to share my understandings. This sharing is like what Lincoln and Guba refer to as member-checking to ensure trustworthiness (as cited in Lavallée, 2009). However, unlike the qualitative analysis literature, which frames trustworthiness as a method to ensure objectivity (Lincoln \& Guba, 2011), there are no similar guidelines for Indigenous trustworthiness. The Indigenous and Nehinuw research frameworks are based on a different set of principles such as ceremony, relationships, and respect (Goulet \& Goulet, 2014; Oleson, 2011; Wheeler, 2010; Wilson, 2008). Lavallée (2009) described how the standard qualitative analysis "tears apart the stories of the participants" (p. 34). She analyzed the themes by telling a collective story based on the themes identified in NVivo. Even though the Indigenous and Nehinuw research frameworks do not have trustworthy guidelines, these frameworks achieve a level of trustworthiness that goes beyond the requirements in the qualitative research framework. For example, in the Nehinuw worldview, trustworthiness is achieved longitudinally by the establishment of life-long relationships between the researcher and participant (Wilson, 2008).

The last component of Nistotên is the understanding of knowledge. My father told me the story how to get to this spot on our traditional territory. He can now say that he understands how to get to that spot on our traditional territory. The cycle of Nistotên for my father was 
complete from experience to sharing to understanding. Similarly, Steinhauer-Hill (2008) describes Indigenous analysis as a dynamic and cyclical process. For my dissertation, I have shared the knowledge that I have learned about Nehinuw governance with the communities a part of this dissertation. While I still have much to learn, I hope that one day I will be recognized as one of the Elders and experts of knowledge on Nehinuw governance. For the moment, I have shared this dissertation in an interactive format so that it can be used as a starting point for discussions on Nehinuw governance theory and practice and educating the youth. I described my dissemination plan in the previous section.

In summary, this story contains three theoretical elements of Nistotên experience, sharing, and understanding. First, there is the experience. In this stage, the individual experiences the knowledge. Second, the individual shares their knowledge by reconnecting with the original Elders and experts. Third, the individual becomes a potential knowledge keeper by showing that they understand. The analysis of this dissertation includes Weetumatowin and Nistotên. I will now provide a detailed overview of the operation of Nistotên in the field.

Once Weetumatowin process was completed, I transcribed the results. After transcribing two interviews, I received a graduate student stipend under my supervisor, Dr. Lavallée's research grant from the CIHR, Institute of Aboriginal Peoples' Health, and Health Canada: First Nations and Inuit Health Branch \#CIHR-AHI 120532. My dissertation links to Dr. Lavallee's (and colleagues) larger research project, specifically the community partner, Motivate Canada's interest in understanding Indigenous governance from the perspective of non-profit partnerships with Indigenous communities. I used these funds to hire a professional transcription service. I ensured that they signed a confidentiality agreement. The service was informed to insert XXX and timestamp when participants used the Nehinuw language. After I received the completed 
transcripts, I reviewed the transcripts for accuracy and reviewed any Nehinuw language terms. Reviewing the transcripts provided me an additional opportunity to review the notes for any potential themes.

Lavallée (2009) effectively used Indigenous research principles, qualitative computer software, and coding in her research design. First, she recorded and inputted transcribed data into the qualitative computer program NVivo. Second, she coded the material using grounded theory in NVivo. Third, she reorganized the initial codes in to higher themes and developed a visual depiction of the themes for participant feedback. Finally, she revisited the themes by telling the collective story. Like Lavallée, I recorded and inputted transcribed Weetumatowin into NVivo. However, following this stage I modified Lavallée's method to accommodate for the Nehinuw worldview. In the second stage of Lavallée's method, she codes the material using grounded theory. I did not use this approach for two reasons. First, grounded theory is a structured, yet flexible, method of "inductive qualitative inquiry" (Charmaz \& Bryant, 2008, p. 374) that helps the researcher discover theory (Glaser \& Strauss, 2012; Grbich, 2013). I do not feel I am discovering or constructing a theory. Nehinuw governance has always existed and knowledge of Nehinuw governance has been held by Nehinuw Elders and experts. Therefore, discovery cannot occur; rather, the goal of this dissertation is to explore governance in Nehinuw terms for the benefit of Nehinuw people because this knowledge has been and is threatened by colonization. Second, I did not see the benefit of using a systematic method of coding in this dissertation. Saldaña (2013) states that "a code is a researcher-generated construct that symbolizes and thus attributes interpreted meaning to each individual datum for later purposes of pattern detection, categorization, theory building, and other analytic processes" (1. 462). Similar definitions have been used in interview methods literature (Glaser, 1978; Grbich, 2013; Rubin \& 
Rubin, 2012; Seidman, 2013). Saldaña (2013) discusses the differences between codes and themes. For Saldaña, a theme is an outcome of "analytic reflection" (p. 14). I used NVivo and coding to identify broad themes or specific concepts that were shared by participants during Weetumatowin. I did not use coding to try to interpret or discover theory shared with me during Weetumatowin. I felt that looking for themes using the Nistotên framework more accurately represented the Nehinuw worldview and research framework and NVivo was a valuable tool to see interconnections between participants.

I coded NVivo in the following ways. First, I recorded and inputted transcribed data into the qualitative computer program NVivo. Second, I used NVivo as an organizational tool to identify themes. Third, I reorganized the initial themes into higher and lower themes. Fourth, I reflected in journal format upon the stories and Nehinuw concepts contained within these themes. NVivo helped me to see the connections between participants on specific Nehinuw governance concepts.

In the final stages of coding I began to reflect on my understandings in a journal format. This journaling is the first stage of Nistotên, which is experience based self-reflection. Ellingson (2011) argues that qualitative researchers should utilize multiple methods of research and analysis, such as journaling. I began by reflecting on the evolution of my understanding of governance. As a long-time student of political science and public administration, I first reflected on Euro-Canadian governance. I then reflected on how the knowledge shared with me during the interview process has changed my understanding of governance. The source of this reflection was not one of the themes identified in NVivo, rather I would review the stories contained within the theme. I would often review the audio file to try to recapture the spirit of the interview. 
Following the experience stage, I proceeded with the sharing stage of Nistotên. In this stage, I contacted all Weetumatowin participants to organize a time when I could share the findings with each participant. I was only able to organize seven additional meetings including four face-to-face and three phone conversations. These conversations were organized following the ethical procedures of the initial interviews and they lasted between thirty minutes and one hour. In these additional meetings, I shared the findings including a summary of the dissertation and the Glossary of Nehinuw Governance Theories and Practices. I asked participants to comment on this research. All participants commented on the value of this research and helped me refine the spelling of Nehinuw terms. Since there was no additional knowledge gathered during this state and I followed the original conditions of Weetumatowin, I did not provide consent forms or honorariums. In one face-to-face meeting, which was conducted in a public location of the participants choosing, I did buy coffee. These discussions took place December 2015 and June 2016.

For the final stage of Nistotên, I planned to organize one community engagement event in each community. However, due to scheduling issues I ended up organizing three one-hour community engagement events, two events in Cumberland House and one event in Opaskwayak Cree Nation. The community engagement events in this dissertation were not designed to gather additional knowledge. They were organized as part of the final stage of Nistotên, to prove that I understand the topic of my dissertation. I conducted three community engagement events in collaboration with the same local leadership that signed the research agreements for this dissertation (see appendix B). On February 22, 2017, I conducted a community engagement event with the Cumberland House Mayor and Council. The Mayor and two Councillors were in attendance. On February 23, 2017, I conducted a community engagement event with the 
Cumberland House Chief and Council. The Chief, two Councillors, one Senator, and two Elders were present. On May 9, 2017, I conducted a community engagement event with Opaskwayak Cree Nation Chief and Council. There were 15 people in the community engagement event including Chief, Vice Chief, several Councillors, representatives from the Assembly of Elders, and staff. In total, 24 people attended these three events, which included leadership, interested community members, and 11 women. Three individuals had participated during Weetumatowin. These community engagement events lasted between 30 minutes and 1 hour.

I began the community engagement events with a short introduction to my dissertation and shared the results of my dissertation including the Glossary of Nehinuw Governance Theories and Practices, see section 6.2, to encourage dialogue and feedback. The community engagement events were highly interactive, and participants were engaged in the material. Once the discussion came to a natural conclusion, I shared two text documents with all participants including a dissertation summary and the Glossary of Nehinuw Governance Theories and Practices. I provided the glossary in digital format on a USB memory stick. This glossary is not meant to be a definitive list of theories and practices; rather, I shared this document with the communities, so they can edit the glossary to include additional terms. Once my dissertation is completed I will share the final draft of my dissertation with the communities. I hope beyond this dissertation these communities will view me as a knowledge keeper of Nehinuw governance, but I know I still have much to learn. All final information was shared with the community, so the community may do as they wish with the material. I envision this document to be accessed and edited by the community and used to pass on the knowledge of Nehinuw governance. 


\subsection{Trustworthiness}

Trustworthiness is the application of quantitative values into qualitative research such as objectivity, generalizability, reliability, and validity (Creswell, 2013; Given \& Saumure, 2008; Miller, 2008). Qualitative sampling sizes occurs in the range of 15-50 participants (Creswell, 2013; Mason, 2010). However, Guetterman (2015) notes that across multiple disciplines and approaches there is no definitive sample size or sample strategy. Furthermore, validity is "established when conclusions are drawn from a variety of data sources using a variety of research strategies" (Dallimore, 2000, p. 163). In other words, trustworthiness is achieved by quantity and quality. In addition to considering qualitative research standards, this dissertation also considered Indigenous research principles. This dissertation has achieved qualitative and Indigenous standards of trustworthiness.

I conducted 12 one-hour interviews, seven follow-up conversations that lasted between thirty minutes and one hour, and three one-hour community engagement events for 24 participants. This sample size quantity and quality meets established research principles. Similar Indigenous research (Alexie, 2011, Makokis, 2001; Simpson, 1999, Sinclair, 2007; Steinhauer-Hill, 2008; Wastesicoot, 2015: Wilson, 2007) has been conducted with between one and fifteen interviews. Alexie (2011) conducted nine interviews lasting from forty-five minutes to several hours. Makokis (2001) conducted her study of Cree leadership using seven interviews. Wilson (2007) conducted her research using four interviews and four group discussions. Sinclair (2007) gathered narratives through fifteen individual interviews and one talking circle.

In the broader context of Indigenous trustworthiness, there is no similar position on validity; rather, validity is thought of in different ways. Wilson (2008) used the framework of "relationality" (p. 80) to set a standard of validity. In this framework, it is not the quality or 
quantity of interviews that matters, but the quality of the relationship that is built between the researcher and participant. Returning to my participants to discuss the results of this dissertation contributes to the trustworthiness of the data. I returned to my participants and the community to discuss the results of this dissertation with an effort to include their voices because I see the final product as something that is collectively owned by the communities. Furthermore, the method of analysis used in this dissertation is similar to triangulation and provides an additional measure of validity. Nistotên contains three components - experience, sharing, and understanding. These stages are like horizontal validity that would be achieved by continually interviewing the participant (Creswell, 2013). Thus, I feel that the multiple stage approach I have used for Nistotên achieved triangulation and adds to the validity of this study.

Finally, this dissertation is trustworthy even though I have relied on a few key scholars, including Keith Goulet and Dr. Lynn Lavallée, to help support the theoretical framework and methological approach used in this dissertation. I agree with Steinhauer-Hill (2008) that in an Indigenous research paradigm, Indigenous people rely on a few sources, such as one Elder, to provide a theoretical framework. An Elder is not considered academic by western standards, but Elders are academic sources for Indigenous people. Steinhauer-Hill provides a justification for this position by turning the logic that has discredited Indigenous knowledge onto the foundations of western research.

In academic research, what I refer to as western research, well known western philosophers such as Plato and Socrates are recognized for their knowledge. In regards to this work Elders are seen and recognized as the philosophers and theorists within this framework. (Steinhauer-Hill, 2008, p. 24) 
Thus, my reliance on a few key scholars, especially a Nehinuw like Keith Goulet, is justifiable within an Indigenous research paradigm. There is no specific legislated process that defines who is an Elder or how to become and Elder. Elders are individuals that have "had enough life experience to have something to offer those behind them" (Steigelbauer, 1996, p.

41). I would consider Keith Goulet and all the people I talked to in this dissertation to be Elders because in addition to being recognized and identified by the community, each participant has had significant life experiences, and in every instance, I felt that they all had knowledge to offer me.

\subsection{Assumptions}

I have made several assumptions in this dissertation, and I have taken appropriate steps to accommodate any issues caused by these assumptions. First, I assumed that participants accepted me as local and Nehinuw. Swisher (1986) refers to inside researchers as authentic researchers. Often authentic researchers can access additional stories or information that would not be available to outsiders. I feel that I am an authentic Nehinuw researcher because I have lived in both communities and my family is well known in the area. Second, I assumed that all participants would speak to their genuine experiences. Wheeler (2010) explores many aspects of Indigenous oral tradition. Within the framework Indigenous oral tradition, Indigenous people truthfully share knowledge by providing credit for specific knowledge through oral citation. I believe that Indigenous people are serious about passing on knowledge through our oral methods and none of the participants would falsify the stories that were shared with me during Weetumatowin. Third, I assumed that participants would be able to understand the English questions that I asked during Weetumatowin. I am not fluent in the Nehinuw language, so I had a list of guiding questions. I did not use this list of questions to rigidly progress through 
Weetumatowin. Each knowledge-sharing event was a conversation, and as I progressed further into this dissertation I integrated any Nehinuw concepts I had learned into subsequent conversations. For example, in the first interview a participant mentioned the Nehinuw concept of Ohcinêwin. I did not know that term and my research questions did not address this concept. In subsequent conversations, I would ask participants about Ohcinêwin. At no point during Weetumatowin did any participant ask me for translations or clarifications on the questions asked. Finally, I have assumed that Indigenous people are unique. Thus, I believe Indigenous knowledge is unique and worthy of study. In my case, I am interested in the subfield of Indigenous governance. However, I recognize that part of what makes Indigenous people unique is how they have faced colonization and I believe that appropriate research on Indigenous knowledge can lead to decolonization. The important distinction that I try to make in this dissertation is to explore a specific body of Indigenous knowledge because I want to highlight the diversity of Indigenous knowledge. I make this distinction because I feel that there is considerable amount of research, completed by both Indigenous and non-Indigenous researchers, that does not address the problems with the homogenization of Indigenous people.

\subsection{Limitations}

I faced four significant limitations that were expected and unexpected. First, I am not fluent in the Nehinuw language. I expected this limitation, and I accommodated for this limitation in several ways. Weetumatowin (knowledge gathering) was conducted in English. However, as I learned the appropriate Nehinuw terminology, I incorporated these terms into Weetumatowin. When I encountered new Nehinuw concepts that I did not understand, I would either ask for the translation of these terms, talk about these terms with other participants, talk to my father about these terms, or utilize my knowledge of Nehinuw. Throughout this dissertation I 
discussed the findings of my dissertation with all participants to ensure that my interpretation of Nehinuw governance was accurate. Finally, all results were shared with the communities in an interactive glossary to ensure continued dialogue on this topic.

Second, I focused on two Nehinuw communities even though there are several Nehinuw communities with a territory that extends across three provinces. Thus, to what extent does this study represent all Nehinuw? I do not claim that this will be a definitive guide to Nehinuw governance applicable across the entire Nehinuw territory. The result of this dissertation is designed to be a dynamic document that is a starting point for community discussions on Nehinuw governance. In the future, I would like to travel to other Nehinuw communities to continue to discuss Nehinuw governance. At the same time, there is no central Nehinuw identity authority. Thus, there may be a perception that only certain people, based on the identify classifications, such as Treaty, Status, or Métis, have or do not have access to Nehinuw knowledge. I have grown up in this area and witnessed how the exclusionary principles of Canadian Indigenous policy have created divisions between our people. I tried to address this limitation by relying on community leadership to identify potential research participants. All participants were selected based on community input, like the community-based research framework (Minkler, 2005; Zraly, Mugengana, \& Walton, 2015). I did not ask participants to identify their identity classification, such as Status, Non-Status, First Nation, Métis and so on. I believe this approach empowers the community to select the most appropriate candidates for this dissertation.

Third, the central research question of this dissertation was exploratory. I designed this dissertation to be exploratory because I wanted to learn about Nehinuw governance in Nehinuw terms for personal reasons and this topic had not been addressed in the literature. However, there 
are concerns that this exploratory approach misses an opportunity analyze the status of governance in the Nehinuw nations central to this dissertation. I agree that much can be learned by analyzing the governance processes that occur in any nation, but I decided not to complete this type of analysis because I had only achieved consent to explore Nehinuw governance in Nehinuw terms.

Fourth, I selected participants using the snowball selection method. I used this method, because I wanted to empower Indigenous communities in the research process and I believed that my specific focus on Indigenous knowledge would lead to a balanced selection of all genders. In the first stage of my research, I ended up with two women out of twelve participants. I decided to continue my research, because I felt that this lack of representation was a result of the community-based snowball selection method and I thought that the additional stages of my research would balance out this lack of gender participation. While more women participated in the later stages of my research, I have realized that my gender view of the selection method and topic was naïve. I agree with Napoleon (2009) that more needs to be done by Indigenous people to ensure that we are hearing from Indigenous women and all genders. In future research, I will not assume that topic and methodology is beyond gender analysis. In fact, I would like to pursue future research that intentionally analyzes Indigenous Governance through gender. For example, organizing a woman-only forum on Governance. As a self-identified Nehinuw man, I would exclude myself from such a forum.

\subsection{Delimitations}

While there is a call by some academics to develop an Indigenous policy analysis framework (Abele, 2007a; Maaka \& Fleras, 2009) or the creation of Indigenous constitutional documents (Abigosis, 2003), this dissertation did not attempt to create any model governance 
documents. Instead, this dissertation explored the broad concept of Nehinuw governance. The dissertation was designed that way to explore Nehinuw governance in Nehinuw terms. I have produced a dissertation and a Glossary of Nehinuw Governance Theories and Practices, but this work is meant to empower and support the community.

This dissertation did not focus on the Canadian Indigenous governance framework, such as the Indian Act, Band governance, or Chief and Councillors. I made this decision because I see this dissertation not as the exploration of how decisions are made within the Canadian Indigenous governance framework, which has been extensively explored (Abigosis, 2003; Beatty, 2006), rather it is designed to be an exploration of Nehinuw governance in Nehinuw terms. To focus on Nehinuw governance, I framed all my guiding questions around Nehinuw knowledge on governance. Furthermore, I did not require that participants had experience as a Chief or Councillor, but participants were free to discuss their experiences in the Chief and Council system. Finally, the snowball selection method led by the community does allow the community to identify people that broadly have knowledge on this topic. However, there is no denying that the Canadian Indigenous governance framework has had a profound impact on the Indigenous governance. I do not know if it is even possible to explore an unimpacted body of knowledge. I do believe that knowledge is alive and contained in the language despite the impacts of colonization which is why I chose to explore Nehinuw governance in Nehinuw terms. I want to support the resurgence of Indigenous governance theories and practices.

Finally, I want to address the use of the term traditional knowledge within this dissertation. There is no globally accepted definition of traditional knowledge and its use only recently emerged in academic research in the 1980s (Berkes, 2012; Grenier, 1998; McGregor, 2010). The 1992 United Nation Convention on Biological Diversity recognized traditional 
knowledge as "the knowledge, innovations and practices of Indigenous and local communities around the world" (Secretariat of the Convention on Biological Diversity, 2016, para. 1). Thus, international principles of traditional knowledge include Indigenous knowledge. As Castellano (2004) discussed traditional knowledge is a body of knowledge that is rooted in an Indigenous worldview. In addition to the connection between Indigenous and traditional knowledge, Berkes (2012) argues that there is considerable overlap and interchange between traditional, Indigenous, and ecological knowledge and the recognition of this knowledge is a positive development. For example, the Canadian legal system has recognized Indigenous traditional knowledge in Supreme Court decisions (Battiste \& Henderson, 2000).

While I am encouraged by recognition of traditional knowledge, I prefer to empower Indigenous knowledge by recognizing Indigenous knowledge as knowledge. This empowerment means that I reject labelling Indigenous knowledge as traditional knowledge. Furthermore, I feel the use of traditional knowledge fixes knowledge to the past when I feel that Indigenous knowledge is highly adaptable (Borrows, 2010). Additionally, classifying Indigenous knowledge as "traditional" makes it less valuable (Battiste \& Henderson, 2000). In support of this view, Deloria Jr. (1997) argues that western science devalues and discredits Indigenous knowledge. Ladner (2001b) extends this argument to the field of political science. Thus, instead of referring to Indigenous knowledge as knowledge, it is labelled as "traditional" and disregarded (Jetté, 2002). The connection with traditional knowledge has done Indigenous knowledge disservice (Irlbacher-Fox, 2014). Finally, I agree with Simpson (1999) that non-Indigenous people have framed the field of traditional knowledge and have removed the agency of Indigenous people in their own knowledge. 
The challenge is that traditional knowledge has been widely used in the field (IrlbacherFox, 2014). In fact, "Aboriginal peoples in Canada have been at the forefront of stating that traditional knowledge should be an integral part of environmental governance and resource management decisions" (McGregor, 2010, p. 232). In recognition of its prevalence, I used traditional in the field, but in this dissertation, I refer to Nehinuw knowledge as knowledge and I do not apply the traditional label. In my future work, I will continue to avoid using traditional when discussing Indigenous knowledge

\subsection{Pe-wicîhin}

I have had the privilege to be educated on the land according to the Nehinuw worldview. Yet, a considerable amount of my education has also occurred within the western non-Indigenous education system. I completed a Bachelor of Arts in Political Science, a Master of Public Administration, and now a Ph.D. in Policy Studies, the pinnacle of the western education system. I have always found myself rebelling and challenging dominant perspectives. This rebellion was no different when I began to design this dissertation. Mainstream approaches did not feel like the appropriate way to explore Nehinuw knowledge. I wanted to honour my people by conducting research according to our research principles.

I centered this chapter around the Nehinuw concept of Weechihitowin. I see this concept as more than a teaching philosophy, Weechihitowin is a methodology. In this chapter I discussed the theoretical and practical basis of Weechihitowin. I am still not the expert. The participants of this dissertation are some of the knowledge-keepers in my community. I could not have completed this dissertation without their help. In Nehinuw, when we ask for help we will say, Pe-wicîhin (come and help me). I thank you for coming to help me. In the following chapter, I will attempt to share their knowledge on Nehinuw governance. 


\section{Chapter 4: Weetumatowin (Sharing stories)}

\subsection{Stories of Nehinuw Governance}

In a standard dissertation, this section would be titled "Results". I am trying to structure this dissertation according to the Nehinuw worldview. I feel that it is more accurate to frame this chapter around stories on Nehinuw governance. The Nehinuw people share stories through three basic frameworks and 15 different sub-forms. Weetumatowin is a narrative framework that focuses on the sharing of information (Goulet \& Goulet, 2014). For a more detailed discussion see section 3.2. Thus, I am calling this chapter Weetumatowin because this dissertation is about sharing stories of governance.

When I began this dissertation, I knew that I had much to learn about my people and Nehinuw governance. I still have much to learn, but Weetumatowin has helped me Nistotên (to understand) Nehinuw governance. I have structured this chapter to reflect how Weetumatowin helped me understand Nehinuw governance theories and practices. I will share theories and practices of Nehinuw governance, as they appeared chronologically during Weetumatowin. For example, the first theme I will discuss is Kihtêyak (Elders). While the first participant did not use this term, once I learned this term, I used Kihtêyak in my research and practice. Within each theme, I move between respondents to highlight related stories. For example, the first theme is Kihtêyak. Kihtêyak was the first concept discussed by Respondent 1 . We see this noted by the Respondent 1 indicator. In the following paragraphs, Respondents 8 and 3 are responsible for two subsequent stories. This conflicts with my chronological structure. The themes are structured chronologically, but the stories within the theme are designed to tell the story of that specific concept. I may fluctuate between English and Nehinuw within these themes to accommodate for terminology used by my participants and identified in the literature. 
After I share the stories of Nehinuw governance, I will spend some time discussing how NVivo has helped me Nistotên (to understand) Nehinuw governance. Finally, I will discuss the Glossary of Nehinuw Governance Theories and Practices that I created during this dissertation. This glossary is framed around the Nehinuw concepts identified by my participants. I provide a translation of each concept in this glossary. I do not consider this to be a definitive list of Nehinuw governance theories and practices. I envision that this glossary will be a starting point for discussion and knowledge sharing in the Nehinuw community. Several other Nehinuw values have been compiled into a glossary at the end of this dissertation.

Weetumatowin began in August 2014 and was completed by October 2014. I followed the procedures and protocols of Weetumatowin that I explained in the previous chapter. Based on my evaluation of Weetumatowin, I have identified eleven Nehinuw governance theories and practices. For each concept, I will discuss the importance of this concept, support this comment with a quotation, and finish by commenting on this concept. I will provide several quotations on each theme.

\subsection{Kihtêyak (Elders)}

To build a relationship and guide the discussion towards Nehinuw knowledge on Nehinuw governance, I began Weetumatowin by broadly talking about traditional knowledge. Participants started by discussing the role of Elders. In the Nehinuw language, we refer to Elders as Kihtêyak. Kihtêyak are important because they are viewed as knowledge- keepers.

Stiegelbauer (1996) acknowledges that there is no universal definition of an Elder, but Elders are often older, recognized by their community, and have "knowledge of some aspect of tradition" (p. 39). Steinhauer-Hill (2008) describes Elders not just as older people but as philosophers who establish theoretical frameworks and provide guidance and knowledge on a variety of topics. 
When we want to learn about Indigenous knowledge and governance, it is critical to recognize the importance of Kihtêak because of their experience and knowledge.

I had heard various stories about the role of Kihtêyak, and I have always held Kihtêyak in high regard, but I had never formally sat down and asked anyone why are Kihtêyak important or what is their role in our society? However, as soon as I began this dissertation I knew I would be really learning about my people. The first question I asked was how do we, the Nehinuw, gather and pass on knowledge. Kihtêyak play a central role in the transmission of Nehinuw knowledge.

Respondent 1: We learn from stories and talking to Elders.

Stories and Kihtêyak are fundamental to the Nehinuw. Kihtêyak are more than old people. Kihtêyak are knowledge-keepers, and their knowledge was fundamental to Nehinuw families and communities.

Respondent 8: The Elders taught us. The Elders talked to us and counselled us. [They were] parents and grandparents. There were specific Elders in the community that were handpicked, chosen because they were good speakers, orators and knew how to explain the rules of the community. So they were very good at [orating]. I remember going on fishing camps down the river and there were groups that weren't together in the fishing camp but they used to meet and talk on how they were going to live together and what their roles and responsibilities and rules.

Respondent 8 identifies that Kihtêyak were teachers and knowledge-keepers. Also within this story, Respondent 8 refers to the selection process of Kihtêyak. Kihtêyak are chosen for their skills and knowledge. Further on in our discussion, Respondent 8 elaborated on the 
selection process of Kihtêyak. Each Kihtêyak had knowledge about a specific topic, and Kihtêyak were consulted based on their knowledge.

Respondent 8: The values and principles of our culture, our tradition and that can be explained by the Elders. There are many groups [of Elders]. There's treaty land entitlement Elders, there's treaty commission Elders and they're all very knowledgeable about our history in that area. But at the same time every community or organization should have a committee or council of Elders within their systems.

Kihtêyak were selected for their specific knowledge. The selection of Kihtêyak is like the selection of leaders in Nehinuw governance. I will expand on this concept when I discuss Okimâwiwayin (leadership law) further on in this chapter. For the moment, I want to continue to explore the role of Kihtêyak. Another central component to the knowledge of Kihtêyak is historical knowledge.

Respondent 3: We worked with Elders who have specific knowledge in different things because they had worked with Elders in the past who told them what type of discussions took place at Treaty negotiations. So when you came to such things like when we talked about resources; they looked at it as unfinished business. They would say, 'we gave you the use of the land to the maximum use of the plow, not everything below it. We still haven't discussed that'. So [when talking about Treaty] it's always to the depth of the plow. So that term came about Ê-iskopitat kistekan you know it's the plow they would use the gesture of two hands and the horses. It was only the depth of the plow they gave you, not all the minerals. So 
they see, for instance, mineral rights as unresolved, unfinished business. So treaty Elders always looked at that particular process [as unfinished]. [That term, $\hat{E}-$ iskopitat kistekan is] still used to quite an extent.

Cardinal and Hildebrandt (2000) reference numerous instances of Kihtêyak referring to the depth of a plough. For Venne (1997), land was not part of Treaty negotiating because women, as caretakers of the land, were excluded from negotiations. In addition to being sources of knowledge, Kihtêyak had a significant role in Nehinuw decision making processes.

Respondent 11: As a community, it was a collective of Elders. Women were not, I don't remember women being too vocal. I always remember the women sitting in the back while the men were in the front. There was really no leader that was chosen. Everybody's voice counted. Everybody had to have a say. It didn’t matter [what family you were from]. I used to sit with them. I'd listen to them, eh. They would all make a decision and they'd come to an agreement.

This story reveals two important, yet conflicting issues. First, Nehinuw governance was a collective of Elders that attempts to hear all voices in the community. However, at the same time the respondent observes that there was a lack of women involved in this circle. As recognized by Napoleon (2009) and Snyder (2013), women are often excluded from discussions on governance and traditional knowledge. This exclusion was created by Euro-Canadian polices that were designed to exclude women and the legacy of these policies on Indigenous society. I agree with Snyder (2013) that more needs to be done to ensure that women are being heard in this discussion on Indigenous law and governance. By not designing a gender component into 
this dissertation, I have missed valuable knowledge on Nehinuw governance. For example, I recently attended Kappo's (2016) presentation Mîkistahikâcimo (To Tell a Story through Beadwork): Revitalizing Indigenous Governance Practices through Beaded Narratives. In her research, she explored how beadwork is an expression of Indigenous governance. Many participants in her research were women and the outcomes of her research were interesting and unique. When I began this dissertation, I thought it would not be necessary to explicitly set a gender target for participation. I assumed that my reliance on community input to select participants and the specific topic of Indigenous knowledge would lead to an equal selection of men and women. But that was not the case, as I ended up interviewing only two women out of the twelve participants. The only gender balance I achieved was when I presented this research to the communities in the final stage of Nistotên. The impact of this naïve oversight is that the results of this dissertation do not adequately represent gender perceptions of governance. In future research, I would not assume that the method will lead to a gender-neutral selection of participants, and I will build in criterion that specifically focuses on Indigenous women.

Clearly, Kihtêyak were invaluable sources of knowledge. Kihtêyak are more than a source. It is critical to begin Nehinuw governance by listening to the Elders.

Respondent 11: So any time that we [gathered], we'd listen to the voices of the Elders. So if there is a new initiative that I wanted to introduce into the community, [we] would take tobacco to every Elder. And once you give them that tobacco it's like it gives you that obligation that you're going to share your knowledge. So that there's an exchange of gifts. So if you take [the gift] then you must participate. You're not going to do anything if the Elders do not agree to it first. Because it won't work. You must have a blessing of an Elder before you go on to do, to 
achieve anything basically. So that's the upbringing that I had. That's what I carry through.

Kihtêyak are Elders and experts, and they must be consulted when developing new projects. The Nehinuw are taught from a young age about the role of Kihtêyak. When you learn about the role of Kihtêyak, you also learn about Nehinuw governance.

Respondent 8: Governance starts at an early age. Kids are taught history. Kids are taught protocol. The protocol would be Elders are important and must be looked after by the community, also widows and people in general that can't help themselves, fend for themselves. So that's how that goes [and] how it's managed.

One final interesting story on the role of Elders was on their role in contemporary society. Respondent 8 was reflecting on the changes in Nehinuw society. Respondent 8: The way we did things and I happened to see the tail end of an era where there was a lot of input from the Elders of the community for advice based on experience and knowledge of the issues. So now you are starting to see a wider range of who's all dealing with an issue in a community. It wasn't until the midsixties that they started using Robert's Rules of Order, that means debate and voting. But in time we got used to other practices like who's for and against and vote on it and that pretty much you know the old ways started to change.

The point of this story is not that we no longer look to Kihtêyak, but Kihtêyak were the source and beginning of Nehinuw knowledge and governance. Kihtêyak are still part of 
Nehinuw governance, but, as the respondent alludes to, contemporary process places more authority on the elected officials. I did not mean to explore the role of Kihtêak in contemporary Nehinuw society, but this point would be interesting to explore in future research, specifically how do Kihtêyak feel about their participation in Nehinuw governance.

\subsection{Kiwicîtowek Insiniwuk (Helping/working together)}

Within the theme of Kihtêyak, there were several references to community. Community is a central component to the theories and practices of Nehinuw governance. My participants talk about community in two fundamental ways. First, the community is a physical location. For the Nehinuw, like other groups of Cree (Brightman, 1993), community is highly relational, and the function of community has changed. In this dissertation, I am going to focus on three community concepts, Ê-tetayan, Otênaw, and Kitaskinaw. Second, the community is more than a physical place; community is a decision-making process. I will finish this section by discussing Kiwicitowek Insiniwuk, which is the Nehinuw concept that described how people work together.

\subsection{1 Ê-tetayan}

E-tetayan is the Nehinuw concept that is used to refer to specific territories that were managed by families. These territories were critical because the Nehinuw occupied territories based on families. A family is more than a source of knowledge. Families were central to the traditional land usage of the Nehinuw.

Respondent 3: If you look throughout Northern Saskatchewan, families had territories. Ê-tetayan that's where [he] comes from, that's his area, these families had that sort of thing, but it was a total area right? That's [their] territory and that's where his family is. The imposition of schools forced them over into the community and more sporadically back into the territory. 
Respondent 3 ends with an extremely interesting point on the educational impact of moving off the land. On one level, the shift to community lifestyle has decreased the pedagogical role of families. Furthermore, the imposition of the western education system has fundamentally shifted Nehinuw pedagogy. Thus, the Nehinuw, in addition to dealing with the intergenerational trauma of residential school, are dealing with the impacts of an intergenerational pedagogical shift.

While there have been many positive developments in the education system, such as increased use of land-based pedagogy, the current education system still relies on the provincial and western educational framework. I believe that we should dismantle the education system to focus specifically on Nehinuw knowledge. However, I also realize that Nehinuw knowledge is a living tree that has roots in the past yet is adaptable. For example, computers are a recent technology that should be taught in the education system. The key question that needs to be asked to address the impact of the intergenerational shift, is what are the core Nehinuw values and pedagogies? The family was clearly integral to Nehinuw pedagogy, and we need to provide a way to incorporate families.

One participant discussed the kinship concept of Nitotêm (clans). This terminology is different from other concepts discussed by the participants. I was familiar with the clan organization system, but I had never been taught the clan system. From my understanding, clans are an Anishinabek teaching. For example, Relland's (1998) thesis provides a detailed analysis of Bear clan teachings and the source of this analysis is Saulteaux/Anishinabek knowledge. As Goulet (2013, personal communication) explained "the word Nitotêm has a slightly different emphasis. It can be colloquially translated as 'friendship' but the literal meaning is 'those with 
whom I am open to'. It is therefore more of a concept of diplomacy/friendship versus a clan group".

Nevertheless, Respondent 6 shared an important story on the role of clans. For Respondent 6 clans exist within the communities.

Respondent 6: When you talk about communities, there is something called Nitotêm, which means your clan. Each clan has a certain animal that they all look up to. Say are you talking about policy. In my clan, I come from the bear clan, it's the black bear that tells the other bears this is what you need to do. The government is part of everything.

Thus, there are two concepts that could refer to the basic layer of Nehinuw governance $\hat{E}$ tetayan (family territories) or Nitotêm (clans). The question that may arise is, which term is the correct term to define the basic layer of Nehinuw governance. The important thing for this dissertation is not to create a consensus definition because I do not think that is appropriate and the Nehinuw have never come together for that type of discussion. I have used Ê-tetayan, Otênaw, and Kitaskinaw because these terms refer to specific territories. Nitotêm are an

important layer to Nehinuw governance, but Nitotêm would have operated in addition to $\hat{E}$ tetayan. Finally, the prevlance of Nitotêm was debated by the respondents.

\subsubsection{Otênaw}

Another layer of Nehinuw governance is Otênaw, which is the Nehinuw term for community. Respondent 4 elaborated on Nehinuw territory. For Respondent 4, it is important to understand the different parts to Nehinuw territory, including territory and community. 
Respondent 4: So when people say Kitaskinaw (our land) what does it really mean? For example, in the whole delta region in Cumberland? What are the different parts of it? Obviously, it's important to recognize that it is used. You know, trapping, fishing, hunting, outfitting, etcetera. But you have to look at what I would call camps. We do have homelands. We do have places of existence. We do have centres. Ocênas and Otênaw.

Respondent 4 further elaborated that Ocênas were camps of families and that Otênaw is specific communities. Nehinuw communities were extremely dynamic and practical because throughout the year, based on seasonal movement patterns, the family or community would have played a bigger role based on the territory of the people.

Respondent 5: So in the wintertime people would be in family groups and then in the summertime they would come to a bigger place like here at OCN 'Opaskwayak' where there'd be a lot of social activity during the summer. And then come fall time everybody would, again, pack up and move to their winter camps. Okay, so there wasn't a written policy on it, but it was just a pattern that people [followed] for practical reasons. I guess and everybody understood what that was. If everybody stayed together in one community during the winter, it would be hard for the community to survive because the moose and the fishing and all that would be scattered all over the place. So it was easier for families to live in these camps so that they could [do] their hunting and gathering and so on. 
The Nehinuw gathered in Otênaw for several reasons including ceremony, social and to make decisions. There were numerous gathering points for Nehinuw. Meyer, Gibson, and Russell (1992) have done some work charting some of the traditional gathering places for Cree people in the Saskatchewan River valley (see Appendix E).

\subsubsection{Kitaskinaw}

The broadest way that the Nehinuw refer to territory is Kitaskinaw. Kitaskinaw means (our land) and is used to refer to a broad territory. Respondent 3 was the first to elaborate on complex relationship Indigenous people have with the land. The first layer of discussion on the Nehinuw understanding of land focused around a broad definition of the land.

Respondent 3: Elders in the north say Kitaskinaw 'Our land'. It wasn't just a reserve. They were talking about the north. If you look at other places, for instance Patuanak, they used their land very significantly. And Cumberland House does too in the delta up to Sturgeon Landing. Years ago they used to fish at Sturgeon Landing, but not any more. Hardly anybody does any commercial fishing right up to Barriere Lake that was their territory being utilized. In the south, they didn't have that same access. The pass system was more of an imposition than in the north.

Even though the meaning of this word is quite clear, Kitaskinaw literally meaning our land/territory, the Nehinuw language also recognizes the potential to share the land and this concept is used to name a specific community.

Respondent 3: There's a community outside Edmonton, non Cree-speaking people call it We-task-iwin. The Cree word actually means 'sharing of the land'. Wetaskiwin, we share the land with you. If you really pronounce Wetaskiwin, it's 
a sharing of the land. We share the land with you. That's what people understand it to be.

Further on in the discussion with Respondent 3, we ended up discussing the impact the removal of people from their traditional territory shifted the role of Nehinuw land and governance.

Respondent 3: How does that affect a place like Cumberland House? When they introduced welfare in the 50s, it was meant to get people off the land. It was meant to get people off the land because where would the strongest voice be from when they were going to build Squaw Rapids Dam. From the people who were making a living. By being able to make them dependent on another process and no longer living on the land, you weaken the voice.

Clearly, land is important for the Nehinuw. Conceptually, Kitaskinaw is a term the Nehinuw use to understand the land at a broad level. Communities can be referred to as Otênaw. Family and traditional territory is referred to as E-tetayan. Understanding the significance of the land also requires more local and specific terminology. Further research would be required to develop a deeper understanding of Nehinuw land concepts. Keith Goulet is currently completing his doctoral dissertation on this topic.

Finally, underneath these perspectives on the importance of Otênaw, participants recognized that the Nehinuw understanding of Otênaw has changed.

Respondent 3: So when you see people talking about our community, our Aboriginal territory, are two significantly different things. And governments right 
now say your Askonikan (reserve) that's an imposition too but leaders Elders look at it differently they say Askonikan is what we save for ourselves so we live there unmolested. The word Askonikan is still looked at - it's the only thing that was left. Askonikaneek (we reserve), it's reserved for Indians - that's what was left and that's how they look at it. You'll see different approaches. Saskatchewan has finished treaties. They still have Aboriginal territory, but not to the same extent in northern Saskatchewan as they do in southern Saskatchewan. [Some nations have] a very significant traditional territory.

In this case, Askonikan (reserve) is the Nehinuw term for reserve. This term is used in Nehinuw political discussions. According to Respondent 3, for many people the reserve is viewed as the community. We see that the imposition of the reserve system changed understandings of the land between Indigenous people in Saskatchewan. While there was always specific local territories, such as Ê-tetayan, Nehinuw land usage has evolved from something very dynamic to something that is fixed. What has yet to be addressed by Nehinuw society is how these changing concepts have affected Nehinuw governance. I feel that the changes in the language have had major consequences on Nehinuw governance, consequences that will not be possible to address in this dissertation and that are more appropriate for community discussion. The writing of Fanon (1967) helps me to reflect on the impact language has on psychological well-being of the people. For Fanon, "to speak a language is to appropriate its world and culture" (p. 21). In this instance, what is the implication of Askonikan (reserve) replacing $\hat{\mathrm{E}}$ tetayan (family territories)? I would argue that the shift in Nehinuw land conceptualization has 
had significant impact on the psychological well-being of the Nehinuw, and it is an idea I would like to pursue in future research.

\subsubsection{Kiwicîtowek Insiniwuk}

Ê-tetayan, Otênaw, and Kitaskinw are three key ways the Nehinuw think about territory and community. Community was more than a specific institution for Nehinuw governance. The community is also a framework for decision-making. Kiwicîtowek Insiniwuk is the Nehinuw concept that refers to how people work together as a community.

Respondent 3: Survival of the community was important as opposed to survival of an individual. So you still see that struggle today. We have more individualism as opposed to community. You will often hear Elders talk about 'Kayas Kiwicîtowek Insiniwuk' well what was that? A long time ago people worked with each other, people helped each other.

Being part of a community is being part of a collective. This collective body of knowledge dictates knowledge, governance, and spirituality.

Respondent 2: To me traditional knowledge means the traditions. The way we conduct our community planning. How we conduct our community events, our Chief and Council activities, programming, our policies and our bylaws, our land bylaws, the spirituality. And also, how we're governed by the government. And now we're changing those laws that are not suitable to our growth and our development. 
Kiwicîtowek Insiniwuk is more than working together; working together is also about trying to hear from everyone and to work towards consensus.

Respondent 1: Consensus. Where people talk and they made the best possible decision on what to do. On where to hunt, it wasn't a guy said, 'well we'll go over here'. They talked about that and given the knowledge that everybody had. It's an understanding. It was a very simple thing that they would go there because that's where the fish would be this time of year. So it was a group decision or a community decision. [According to law], it was the leaders that made the decisions but it wasn't. It was the community. Of course, women were an integral part of the community. That's how a decision was made about something. It was the community. It was an understanding.

Working towards consensus often meant that leaders and Elders included all voices from the community.

Respondent 7: The rules and traditions, it wasn't written. [When] it came to a given community, Elders were very respected and same with the Chief. So, if there was a problem or an issue, they were the ones that dealt with it. They talked to people or they would go in a group, say the Chief and a couple of Elders would go in and they would talk [to] the family. They didn't think they were doing things [for themselves] because it all reflected back on the entire unit, the First Nation. And it was a way of keeping peace. 
Reaching consensus often required the leader to take considerable effort to talk to everyone in the community. Door-to-door consultation was once a common practice.

Respondent 8: Sometimes the Chief used to go around the homes and discuss critical matters, things of importance to the community because everything had an impact on everyone in the community, families included and that's why there was a lot of consultation going around until the Chief of the day, back in those days, was satisfied that he, in our case we had a Chief that was Chief for 23 years, until he was satisfied that there was enough information to make a decision on. It was not just the Council but it was the community that supported that and that's where the Chief and Council got their power and their mandate in that. Even though they were governing Council, they relied heavily on the people to support their decisions. So there's a lot of consultation and process. In those days, the Chief and some of his Council members would actually go house to house and talk to people about matters that would have a significant impact on the community down the road, that's how things were done in this community.

Another participant elaborated on the concept of Mâmawi-wîcihitowin, which is another way to discuss how the Nehinuw work together.

Respondent 6: Mâmawi-wîcihitowin that's working together. And from there would come other stuff. When it came back to getting things done, moving things and negotiating, all that, it came down to, like, having people skills, people skills and the way you communicate. Everything was done in a consensus. We did not 
make decisions based on one individual. We based our decisions based on the whole.

Another participant discussed the concept of Mamikwaytomatowin, which refers to how the Nehinuw community would come together to resolve problems.

Respondent 8: Consensus there were different words, like for example when you're dealing with a common threat to the community or common opportunity to the community you have to approach it based on the principle of Mamikwaytomatowin, we have to wrestle with this thing together. Not just by the Chief, not just by the Councilors but together the community.

Building consensus required a deep commitment to conflict resolution that would often take days to complete. Breaks in consensus building would allow people to go back to their families to discuss the issue.

Conflict did occur in Nehinuw communities, but people were also prepared to come together to resolve conflict. The main point of this process was to allow people to contribute to the discussion in their voice.

Respondent 6: I may not have agreed with what people were saying but the majority wrote it and I went with it. You know, of course, I expressed my views, views on things based on what I knew and understood. And the consensus part, that's where that came in, we had to listen to everybody's views and then come to a final decision. You know, but like I say we debated things first and we made decision. We just 
didn't say, well, go ahead, let's do this. Said, well, let's try and do this but let's find a way to do it in a good way and that's what we did.

We see here that Respondent 11 discusses the role of women in the Nehinuw decisionmaking process.

Respondent 11: If they couldn't solve that problem in that one sitting, they would continue sitting until they solved the problem. If they had to have another meeting but what would happen then is that people would go back now and they'd start talking to their families. This was not a formal meeting but it was how can we came to an agreement. These decisions had to be one agreement. So that's how they would do it. They'd break up into little groups and then they would come back and the more that you could gather, the voices from the different families, you had to make them see. You had to make them see your decision. But it always was the gathering of the voices first in our language. And then you present it. And that was basically how everything was done. Everyone had a voice. Everyone had a place of respect. And I think our language gave us that. Like, it would, every, anybody was allowed. Even the women. They were allowed to talk. And then they would come back and then they would listen. And then they would see what the other person had to say.

In this case, Respondent 11 refers to how the past system was gender equal since women were included, yet there is also clearly a strong power dynamic as women were "allowed to talk". Napoleon (2009) has done work on this topic. She has two key points. First, if we do not 
address gender, we are highly naïve about our assumptions of "future aboriginal self-government in Canada" (p. 233). Second, "without a concerted and sustained commitment, the oppression of aboriginal women is not going to end" (p. 255). I admit that I have been naïve about my gender assumptions. Like others in the field of Indigenous knowledge (Napoleon, 2009), I assumed that by framing this dissertation within the field of Indigenous knowledge, I would access genderneutral perspectives on Nehinuw governance. I did have women participants but only two out of my twelve participants. Furthermore, I did not design any specific questions that focused on gendered perspectives of governance. I agree with Napoleon (2009) that if we are serious about the future of Indigenous governance efforts must be taken to include men and women, and in future research I will not assume that Indigenous knowledge leads to a gender-neutral conclusion unless we have taken the effort to equally include men and women.

Working as a community is still an integral part of contemporary Nehinuw governance. Respondent 1: As an example, in the education authority when there's a change in the personnel policy, it's an inclusiveness. That's how we did things in the old way. It's an inclusiveness of management, so we hear from everybody that involves people like bus drivers, janitors, teachers, administrators, secretaries. They get all of them together and they send it to management and management looks at it and they take it to the Board and the Board approves it in most cases without changing it. Here is the recommendation coming from this group, the group involved everybody. There is a prime example of how we do it in the old ways and how it is being done today a system of management instead of just the administrator or the director of education writing up the policy. 
In the contemporary context, the principle of Kiwicîtowek Insiniwuk also has a role for Nehinuw governance.

Respondent 1: I feel comfortable in having a consensus reached instead of something autocratic. Instead of the Chief or whoever is running the meeting saying “it is going to be this way." If you haven't had a chance to say how you feel and then the grumble gets louder and louder in the community. As an example, I was an administrator for a long time if a person was mad at me I'd rather go and see that person and talk about it. We'd try and resolve it. If I don't do that, that person is going to tell ten different people. They'll tell ten people about their anger and then that little thing becomes a big thing.

There is a division of labour in the contemporary process that sees Chiefs and Councillors responsible for their own portfolios. However, even with this division, leadership always makes the effort to make decisions based on the needs of the community.

Respondent 10: Well we sit together as Chief and Council and decide. But if every one of us is different we write down the things that we need on our portfolios and that's how we do it. We work together. Nobody works individually. The only individual work you do yourself out here is your own portfolio. But when it comes to our table, we share.

Building consensus is a critical component of contemporary Nehinuw governance because elections are not decided on the same principles of representative democracy as in the 
Canadian system. Nehinuw governance is based on collective vision and decision-making. Within this system, we see a shift from valuing consensus to valuing results.

Respondent 8: But over here it's different at the First Nation level right, it's not based on how many seats you have, it's not even based on party politics but it's all based on a collective speaking, collective vision, collective decision-making processes because what we do at the First Nation level is not for this party or that other party but it's for the community and that's important. That's why it's important to follow the rules of consensus seeking. It's pretty hard sometimes but if you have enough time to discuss an issue you will eventually reach consensus. But everybody is in a big rush now.

The latter part of this story highlights the shift in governance tempo, results orientated governance means that people are in a rush. We can extend Fanon's (1967) psychological analysis to look at how changing values, such as governance tempo, impacted Indigenous society. What is the impact on Nehinuw thought, as there is a move from consensus decisionmaking to result-based governance? Perhaps contemporary Nehinuw thought can adapt to include this shift in governance, but the community may want to discuss the impact of the shift in these values on our community.

Even within the traditional and contemporary process, Nehinuw leadership was pragmatic about the application of consensus.

Respondent 5: Well, there are some groups that are trying to bring egalitarian structure into organizations. There's been a movement there for a while now that that's happening. They are trying to deconstruct this idea of a hierarchal 
organization where the majority of the people are at the bottom and then there's few managers and fewer and fewer until there's the boss. So the idea is that in a circle everybody is included. Everybody is equal and has equal say. But somebody has to start the discussion so somebody in the circle takes the leadership role and invites the people to have a discussion about whatever idea.

Finally, I asked the respondent for thoughts on how outside organizations can better work with Indigenous communities. Kiwicîtowek Insiniwuk is the key framework for creating a better relationship.

Respondent 1: I think outside groups should listen, not to come there with your own agenda, to have an open mind on what this group is doing. Too many times a group comes in and says 'this is what we want to do' [or] 'this is how it's going to be done'. For example, the First Nations Education Act. That's probably a good example. We're so many First Nations, so many groups, it gets harder to do things. How we did things I think it could be done. It would take longer like developing law, developing policies, but the more people you involve, the better the policy or the law will be because you've been informed about it and it's something that they themselves like and they can understand.

For many respondents, the principles of community should influence business between Indigenous and non-Indigenous people.

Respondent 8: Well I think anybody who wants to come conduct business here should know the rules of the community, the values of the community and each 
community is different and you have to know, you have to go out there and know about that community, what's the uniqueness of that community.

Respondent 3 also agreed that knowledge of the community was required to achieve success in the short and long term.

Respondent 3: When you have a good working knowledge of the community, and you have the community in mind as to the end result and the long-term impact, you're going to deal with things in a different way. So I would hope that they would legitimize the process of delivery sufficiently that they could incorporate the use of community members in those processes so that they become part of the system as opposed to being used only on an itinerant basis.

The challenge working between Indigenous and non-Indigenous institutions is that the foundation is built around conflicting values that place tension between the individual and community.

Respondent 7: Yeah, well, we're still trying to operate the way we did back in the 60s and 70s, holistic thinking, group thinking, group benefit and it's almost like communism, pure communism where the people are the actual ones that are really important. And in this day and age that doesn't fit the way everything is laid out, the provincial processes, the municipal processes. A lot of it is based on individuals, governing bodies and stuff like that. 
This respondent has tried to teach non-Indigenous people about community values by visually displaying the key values around their workplace.

Respondent 7: If you take a look at our governance here, we have banners that spell out our values as part of our governance system. There's love, respect. [with nonIndigenous organizations] you don't have that. It's just the policies are cut and dry, they don't conform the people. They're not people based; everything we do is people-based.

Throughout these discussions on Kiwicîtowek Insiniwuk, I began to see that Nehinuw governance required me to dismantle my understanding of governance. In Canadian governance, the institutions are venues for processes of governance. For example, the parliament is the institution that allows for the process of representative democracy. For the Nehinuw, community is an institution of governance, and it is also the method of governance. The decision-making process is structured to serve the needs of the people it serves. I will elaborate more on these differences in the next chapter.

\subsection{Ohcinêwin (Law of the land)}

The first Nehinuw governance concept that was discussed was Ohcinat, a reference to the verb form of Ohcinêwin, which is law on the land.

Respondent 1: You sit around the fire and the stories come out and interspersed among the stories is all those teachings, different kinds of teachings that happened, how we do things. A good example, 10 years ago we were hunting and we shot a moose. The guy from Saskatchewan was trying to be a jokester and along the way he disrespected an animal, a cow moose, he made reference to mating. We never 
talk like that. We looked at him and you could see the guys, their body language told me something. One guy put his knife down and tore into that guy. The guy asked, 'How come you didn't help me'? I said, 'because you deserve it'. He got jinxed there is a word for it in Cree. Ohcinat.

I had heard of Ohcinat and Ohcinêwin in the past. At that moment, I wondered how a "jinx" would fit into the framework of Nehinuw governance. However, as the interview progressed, it became clear how Ohcinêwin is a key concept to Nehinuw governance.

Respondent 1: This guy couldn't kill for the next couple of years. He'd see a moose and put a wrong bullet, he'd freeze, or the gun wouldn't work. All kinds of things would happen even if it was a sure kill. Finally, he acknowledged what he did. The Elder said 'Yup, you got to show respect. You can't do that'. Shortly after that that guy phoned me, 'Hey I killed a moose'. As an example it's not so much government but I think everything in our life as Cree people is intertwined like this.

The key point of this story being that Ohcinêwin is a form of governance that exists on the land. There are references to Ohcinêwin in the literature. For Goulet (2013), Ohcinêwin is the set of consequences that result "from a failure to abide by Cree law" (p. 19). Goulet provides several examples of punishments that may be given for any offence. For example, "Apehowin is revenge" (p. 19). For McAdam (2015) Ohcinêwin means "breaking of law against another other than a human being" (p. 44). Respondent 5 referred to Ohcinêwin as natural law. 
Respondent 5: Let's see, sacred law, natural law, what's the word for that? Can't think it at the moment. Other than referring to 'Ohcinêwin'. Ohcinêwin is natural law.

When I combine these stories, I see that Ohcinêwin is a key doctrine of Cree law. Consequences for breaking Ohcinêwin can be individualistic, but in certain cases depending on the severity of the issue, your entire family could be impacted. Community input would have been considered when there was an offence under Ohcinêwin. I did not try to collect a list of offences or punishments during this dissertation. Goulet (2013) compiled a list of 12 potential punishments including a detailed breakdown of a process that might occur under the doctrine of Ohcinêwin.

Meskotehowin was a punishment of redress. Kakweskasowehk was reproval. Apehowin was revenge. Naskwawin was reprisal. Pasastehkakewin was retributive justice. Naskwastamasowin apo apehowin was when vengeance was taken. Pasihiwewin was vindication. Atameyimew was blame. Siskiskakewin was obligation. Masinahikepayowin was indebtedness, and Tipahikewin was recompense. (Goulet, 2013, p.19-20)

\subsection{Wahkohtowin (Law of relationships)}

Ohcinêwin was the first doctrine of Nehinuw law that I encountered during Weetumatowin. As I progressed further into Weetumatowin, I began to encounter many other Nehinuw legal doctrines. Wahkohtowin was the second doctrine that I encountered. Wahkohtowin is a Cree concept that refers to the laws governing all relations (O'Reilly-Scanlon, 
Crowe, \& Weenie, 2004). While the second participant did not specifically use the word Wahkohtowin, the participant emphasized the importance of relationships in the community. Respondent 2: When I was growing up as a family you are taught the teachings. You were taught respect, being humble, respecting the Elders. So when we were growing up we never called anybody by their name. It was either kimosom, kokom, kitosis, or nisikos. You never heard, you know, by name. So I think the community grew that way. And from family they learn as a family. And pass it on into the community.

I realized that families are more than social organizational units. Families have specific territories Ê-tetayan. Family relationships are also a fundamental Cree legal doctrine, Wahkohtowin. There were specific protocol and polices in place to implement Wahkohtowin.

Respondent 6: Based on our language you ask for policy. You have to know your language to begin to understand all these things. Like Wahkohtowin, when you talk about policy, there's policies there, how relationships should be. You start from our language. And that's what I am thinking when you talk because there was no such word as policy but all those key words in our language. And from there flew certain things that you have to recognize.

Wahkohtowin is dynamic and built on a foundation of respect.

Respondent 5: Well, the one thing is that families are important because of the extended family or like the kinship structure so that my mother's sister's children were kind of like my brothers and sisters, right? My mother's brother's children, 
they were kind of more like cousins whereas the others were more like brother and sister. And same thing with my father's brother's children were kind of like my brothers and like an extended family, right? But my father's sister's children were more like cousins. So that the kinship structure was important. I guess that's another way that decisions were made is that there would be a matriarch or a patriarch in the families kinship structure and people would look to that person to be the 'leader'. And the success of that leader depended on how he dealt with the rest of the family, whether he was trying to be dictatorial or if he involved other people in making the decisions, right?

Wahkohtowin is a method for the community to respond to family crises.

Respondent 7: Their laws were organized, especially child and family services. Back then there wasn't any apprehensions. If the community saw something wrong they would take charge, they would make sure the safety of children. They would place kids into, directly into relative's houses. Relatives would step up and take over children if there was a problem that needed to be looked after. So, there was a lot of things that were laid out, that weren't written down.

While each family lived in their own territory, responsibility to family extended to all people in the area.

Respondent 9: Mostly this group, this 'Pasqua' here this opening. That was our family. So the community they did the same thing. My 'Stosin' lived with our family. Our relatives so our grandmother taught [them], treated them like their kids, 
her own kids. So they practiced what her family practiced too. And that was good too.

Learning about the detailed protocols of Wahkohtowin, I realized that Wahkohtowin is an additional doctrine of Nehinuw law. Clearly, Nehinuw governance is highly complex. During the discussing with my participants on Wahkohtowin, there were no references to Ohcinêwin. In other words, Wahkohtowin is a separate doctrine of Nehinuw law that operates outside of Ohcinêwin. As I reflected on the connection between Wahkohtowin and Ohcinêwin, I wondered about the structure of Nehinuw law. What is Nehinuw law? How is law connected to governance? Soon my participants discussed Nehinuw law.

\subsection{Wânasiwayin (Law making)}

Following the discussion on the role of the family, I asked the respondent how decisions were made within the family. The conversation shifted towards discussions on law. When I asked the respondent about Cree law and governance the respondent said, "Governance? Wanesewayna means the law. Wanasewatawak setting the rules for ourselves." Respondent 3 offered a further definition of Wânasiwayin.

Respondent 3: Wânasiwayin derives from the verb 'to set things right'. It derives from that verb Wanaseway, Wanastaso. If you look at an everyday occurrence, set the dishes on the dinner table, Wanastaso. It's also the same one that says 'you can make a mess'. Wanastaso means 'you are leaving things in a mess'. It's interesting that one word can mean 'law', it can mean 'setting dishes', and it can mean 'making a mess'. It derives from the word 'to set things'. So when you look at that, how does it translate? 'Wanaseway' like how would you say 'a judge'? Kichi-wansoy 
'the main one that is trying to set things right'. Wansaytanow in Cree for 'lawyer' is one who is trying to set things right. So you're dealing with how to set things right.

Wânasiwayin refers to the process of law making. There are a number of applications of Wânasiwayin.

Respondent 8: The issues of safety and security in the community, there was rules to live by, what they used to call Wanasewaynuk, 'Little rules'. The way it was dealt with back then they would have discussions about it, sometimes long discussions. Now I'm talking about probably a day or a couple of days on an issue until they thought they had discussed every aspect of the issue and then they would agree on what the course of action should be and [that] they all supported.

Wânasiwayin includes life in the family and out on the land.

Respondent 10: Wânasiwayin covers a lot of things. When we were brought up by our parents we were always given a few words not to try and get into trouble, took anything, so the law won't interfere with our families. Because they always say if you get into a trouble like that such as stealing or breaking things or, you know, trying to fight and you get involved with the other people, what they were doing, you know, and these are the things that we were told not to do. And we listened.

Similarly, Wânasiwayin is a comprehensive set of rules that guide individual and community behaviour. 
Respondent 12: What I heard, because I was never really involved with politics, was 'Kawanisawatisiwan'. And that in my understanding of that word it means 'you have to have laws that govern yourself'. So that means you have to have a set of rules that you have to follow. So that would be law because we all have rules that we have to follow. And that's the word that I heard. 'o- kawanisawatisiwan ka-mîno-wanisawatisiwan', meaning 'you have to do a good job at governing your laws that you have, that you use'.

Even though families were independent, Wânasiwayin connected families to communities.

Respondent 2: No, I think they were made as a whole community. We didn't have a family making a law per se. We had the community making the laws. And then when the community makes a law, it has more emphasis. People pay more attention to it because it's - the ownership is there. They develop it. And they see that more as a community controlled than government control.

Despite various interpretations of Wânasiwayin, there is an underlying commitment to community order.

Respondent 8: The closest would be some people use Wânasiwayin, 'law making or making laws'. Wanasewayte with Chief and Council. Okimakan, Okimâw, or Wânasiwayinuk that's people that make the laws. But there's no real clearly defined Cree definition of governance. Ininisihcikewin is another one. Nehiyaw 
Wânasiwayin, Cree law. I think it was more important for us to know how order was managed in the community and who was responsible for specific areas.

In follow-up conversations with my participants, I asked what is the connection between Ohcinêwin, Wahkohtowin and Wânasiwayin? Specifically, if Wânasiwayin is the law, how are these other doctrines of Nehinuw law, such as Ohcinêwin, part of Wânasiwayin? It was explained to me that Wânasiwayin has more to do with how rules are made (Respondent 3, personal communication, February 11, 2016).

\subsection{Askîwipimâcihowascikêwina (Livelihood agreements)}

Many participants discussed the importance of treaty. Askîwipimâcihowascikêwina refers to livelihood arrangements made at treaty negotiations. Treaties are viewed as the central framework to protect the land and structure the relationship between Indigenous and Canadian governments.

Respondent 2: One of the things that we always know upfront is our Treaties. We really use our treaties to protect us, to help us set our policies and our laws and continually to identify how we want to govern ourselves.

In addition to being central framework for the Canadian Indigenous relationship, there is a deep respect for the people that signed treaties.

Respondent 5: But they ended up having to make these treaties with the Aboriginal people and I think our people who made these treaties were visionaries. Just think in the making of the treaties. If our people that signed the treaties went for a onetime payment, you know, selling the land, we wouldn't have any benefits. 
Clearly, honouring the Treaties is critical to reconciliation.

Respondent 6: I'd like to get them to know what the treaties are and what they all mean because the treaties are not just for Aboriginal people, it's for all Canadians. Because if they understood that then they'd be a little more receptive in, you know, learning about them, and taking advantage of them and all that.

Often when discussing Treaties, the conversation is focused on the Canadian Indigenous Treaties.

Respondent 6: We have arrangement with the government, they're trying to say that treaties are not important but they are. Treaties [were] made in good faith.

Yet, Indigenous Treaty theory has a rich history.

Respondent 6: There were treaties that were made long before Columbus showed up in North America, you know?

The treaties were and are central to the relationship between Nehinuw and settler governments. As a form of Indigenous governance, treaties have a long history in Indigenous international relations. While it was not discussed during this dissertation, it would be interesting to explore treaty theory in more detail such as treaties between Indigenous people and the future of Indigenous treaty theory. For example, how can the established Indigenous treaty theories be used to create new treaty. The revitalization of Indigenous treaty theory has started to occur such as the 2014 the Buffalo Treaty (Wildlife Conservation Society, 2016). I find the 
Buffalo Treaty an inspirational source of Indigenous treaty theory because we see in this agreement multiple, in this case 10 Indigenous nations agreeing to support conservation.

\section{8 Âcimowin (Storytelling)}

Âcimowin is the Nehinuw word that describes the process of storytelling. The third interview began with the discussion of traditional knowledge and the respondent began talking about the oral traditions of the Nehinuw people.

Respondent 3: One of the main ways what I [learned was from] listening to my own father. Âcimowin is a word that's used. Achimo in Cree means 'to tell a story'. And you will tell a story in different ways. You will tell a story of a significant personal incident. It can be one of a survival situation of hunting. It could be one of an incident that occurred between a meeting of people or an encounter with another group of people.

As the discussion progressed, the respondent started to discuss the complexities of the oral tradition. Wheeler (2010) writes about the complexities using the concept of "traditional footnotes" (p .58). In this discussion, the respondent used the term oral footnotes.

Respondent 3: It's oral footnoting. By naming a place, who was there, who told you, who reiterated the story. So that's Cree gathering of information. Why is that important? Because if you look back and you understand your own history the Cree gathered information by coming from their places and visiting each other. They would pass on different information and they'd do that in a very specific way - what they experienced, who was there, and what event. I'd see that as a significant 
basis but it lends itself to a process where it's identifiable place, identifiable time, identifiable event - footnote - oral footnote.

Besides reconfirming that Indigenous knowledge is alive and held by the people and in the language, Âcimowin is central to the operation of Nehinuw governance.

Respondent 3: I know [the Federation of Saskatchewan Indian Nations now the Federation of Sovereign Indigenous Nations] did hundreds and hundreds of hours of recording Elders talking on a one-to-one basis. So those recording are there, you know, and we had Elders at the treaty table that gave us not only spiritual guidance but guidance in relation to interpretation of what might have happened back then. And that Elder, Oakes, that I was telling you about earlier - he was at that table - he was significant, so his knowledge was very specific that related to an event that occurred at Treaty making. So it was significant in that there was a great oral footnote of an event and when they discuss the depth of the plow and those types of concepts, he was able to say what happened.

Respondent 4 expanded on Âcimowin as political narrative by discussing the diversity of Nehinuw narrative forms. These forms are connected with the types of discussions that would have been carried out in Nehinuw governance. Different protocols and processes would have been in place for each of these narrative forms.

Respondent 4: All people will have informational systems. But there are certain ways of speaking that Crees have and you have to be a fairly adept researcher to be able to pick those out and that type of work needs to get done. I know that nobody 
even knows the three basic main structures in Cree, Achenokeyin, Achimowin, and Atotumowin. Nobody even knows that Achimowin and Atotumowin are the more up to date forms, have about 15 different sub forms, you know, different ways of speaking.

The oral methods of the Nehinuw are complex. The translation, storytelling or oral tradition does not do justice to the diverse oral methods of the Nehinuw. I am not an expert on these various forms, but I understand that there were specific narrative methods that were used in Nehinuw governance. I would like to conduct future research to look in more depth at the specific narrative forms that are used in Nehinuw governance. For example, what are the specific narrative forms used in Nehinuw governance? This dissertation is framed around Weetumatowin. Is Weetumatowin an appropriate narrative framework within Nehinuw governance or perhaps one of the other forms or subforms would be better fitted to Nehinuw governance?

\subsection{Okimâwiwaywin (Leadership law)}

Participants discussed three Nehinuw leadership theories and practices, Okimâwiwaywin (leadership law), Okimâw (leaders), and Simâkanis (warriors). I have included these three leadership concepts within this section on Okewmawwaywin. Weetumatowin on Nehinuw leadership highlights the dynamic nature of the theory and practice of Nehinuw governance. I will end this section with a brief discussion on the impact Euro-Canadian governance theories and practices had on Nehinuw thought and language. 


\subsubsection{Okimâwiwaywin}

Okimâwiwayin refers to the rules of leadership. Respondent 7 had many interesting points to make on Nehinuw leadership and referred to the rules of leadership as Okimâwiwayin (leadership laws). The specific guidelines were not written but understood by leaders and the community. These rules were passed down generation to generation through oral knowledge and in Kihtêyak (Elders) teachings.

Respondent 7: The Elders would teach by showing you. They would start from scratch. They didn't assume, you as an individual, came in with advanced knowledge of something. They taught you everything you needed to know, like survival skills, tanning skills, how to get wood, how to get water and look after your house. They taught you all that stuff. It was done through Elders too, specifically through mothers and fathers also.

Nehinuw leadership is based on expertise and not gender specific. People would be consulted across families based on their knowledge.

Respondent 5: Leadership was situational. Some families would have one person that was known to be a good hunter so the rest of the family would look to them for leadership in hunting. Somebody would be really good at medicines, so they would become like the family doctor. People would look to them if there was illness or whatever. Same thing if there was a good mediator. If there was conflict, they would look to that person to mediate the conflict. That's why some medicine people are known intercommunity wide or sometimes people will go a long ways to go 
and seek out a particular medicine person because of that they have knowledge about specific kind of medicine.

Leadership was based on expertise and individuals were recognized for their expertise. Respondent 8: People were identified, this guy deals with this and this woman deals with that. If that person didn't have the resources to effectively deal with that then he would take it to the next level which would be the governing Council. There's a certain amount of autonomy by [Councillors] back then. So a simple answer you know to a question like what shall we do to promote prevention. Well it takes a long time to explain that because everything is connected here in the education process, the spiritual aspect to the matter at hand and the social wellbeing of the community. Not everybody was a general practitioner. They all had different disciplines and some dealt with infants, baby issues and some dealt with breathing disorders and some dealt with internal matters.

Being a leader in a Nehinuw community requires a commitment to community, accountability, and responsibility.

Respondent 8: So when you talk about governance, governance there's a lot of principles that come with that. You know being responsible, being accountable are probably two of the biggest ones and more important than others, accountability, responsibility. But at the same time, you had to know how to look at the whole thing, not just health, not just housing, not just education, not just land but everything. If you're going to have good governance, responsible governance one 
has to know, understand I should say the bigger picture here. First of all, the principle it's not about me, it's about the community and everything that we do it's not about us although we benefit from that but it's about these little kids that's running around here. That's what it's all about. The kind of decisions we make must have positive impact on those kids and their kids, that's how far we have to look ahead. So we all have our unique ways, it just so happens in our area here we're kind of like you know in the middle, people coming from east, south to here, west to here and north by the river systems and that, somehow this became a trading area.

\subsubsection{Okimâw}

Naturally, there is a word in the Cree language for a leader. Okimâw is the Cree word that refers to Chiefs and Headmen. The role of Okimâw has been discussed in the literature (McAdam, 2015; Venne, 1997). Respondent 2 was the first participant to expand on Nehinuw concepts of leadership. For Respondent 2, the Nehinuw show respect by calling older people Okimâw.

Respondent 2: In the community when you hear people talking they didn't talk directly to each other. They carried on that tradition when they talked to a fatherin-law or a mother-in-law it was 'Okimâw' or 'Okemaskaw'.

Respondent 3 elaborated on the connection between leadership and knowledge. Respondent 3: Realistically, a Chief would be seen as a leader Okimâkanuk. [The plural form of Okimâw]. There were leaders. There was a Chief of hunting and gathering. There was a Chief to deal with the wrongs done in the community. So 
you had a Council of Chiefs. That's what the leadership was and you govern an area which you were good at and you weren't elected, you were chosen, whereas the imposition of Chief is an elected process of an imposed system of governance. You still see that followed today when they're wanting the government to impose a system they call democracy. Which is an interesting thing because when you look at it, it has all those things that Council of Chiefs made decisions.

Towards the end of this story, respondent 3 started to reflect on Indian Act leadership. There were several interesting stories told on the changes in the Nehinuw language that acknowledge this change leadership. I will discuss these stories further on this section. What I understand from these stories is that the theory and practice of Okimâw was dynamic, knowledge-based, and a highly-respected position.

\subsubsection{Simâkanis}

In addition to having Okimâw, the Nehinuw also had sacred warriors that were used to keep the peace.

Respondent 7: If there was a problem, Elders or Chiefs were the ones that dealt with it. They talked to people or they would go in a group, say the Chief and a couple of Elders would go in and they would talk to the family. They didn't think they were doing things because it all reflected back on the entire unit, The First Nation. It was a way of keeping peace. They were called Simâkanis. That's what they called the soldiers that went to war. They were the ones that were sent out to fight to keep the peace and then to make sure that the whole community kept going, with the freedom and everything else that we had... But if things were frowned upon 
by the community, people would take action. They would talk to you and make sure everything turned out all right. And they had their own policing services. They used to call them Simâkanis.

Respondent 7 was the only participant to refer specifically to Simâkanis. However, when I went back to review Weetumatowin with my participants, other respondents agreed that Simâkanis was an important and ancient Nehinuw leadership role. In these discussions, Simâkanis was translated as a warrior, but the etymology of the word references a spear point protector or leader. The term has also been used to refer to war veterans. McAdam (2015) also discusses Simâkanis. In contemporary times, Simâkanis is used to refer to police. Thus, it would be interesting to explore in future research how has or if the meaning of this word changed? Are there now negative connotations with Simâkanis if it is associated with police?

\subsubsection{Okimâkan}

In addition to the detailed discussions on various Nehinuw leadership theories and practices, the Nehinuw language exposes criticisms of imposed Euro-Canadian governance theories and practices.

Respondent 3: In governance, the Chief is often described as Okimâkan and Councillors were described as Okimâkanuk. Okimâkan, if you translate the word, is a false leader. Why would people call their own Chief a false leader? You know why? Cause there was no one Chief. It was an imposition of governance where they recognized one leader. It was easier to deal with one leader; so they demanded that they meet with one and they want you to select us one Chief. So they selected one but they still called him the false leader, Okimâkan. He's not quite the boss, 
okay? He's not quite the leader and why? Because the Cree govern themselves by a number of Chiefs. We are having this system of governance imposed on us and you don’t truly understand why we call a Chief Okimâkan.

In addition to being a pretend boss, Okimâkan is a disrespectful concept. Respondent 11: The word Chief. 'Okimâkan', a pretend boss, an artificial boss. Because we didn't have Chiefs in our culture. We had collective voice. So now all of a sudden the Indian Act brings a Chief. How you interpret that? 'Okimâkan'. When you say it in Cree it's disrespectful. And it doesn't matter where you go. That 'Okimâkan' is used throughout our Cree territory. Whether you're Swampy, Woodland, whatever. 'Okimâkan'. A pretend boss. An artificial boss. See, our people didn't have respect for, when they translated those key words, they didn't respect those words because there was no words for it.

\subsection{Ininisihcikewin (People ceremony/way of life)}

Several respondents discussed the importance of ceremony for the Nehinuw people. Ceremony was not just a personal event, rather to the Nehinuw people ceremony is central part of Nehinuw governance. None of the participants shared with me the Nehinuw word for ceremony and it did not occur to me during Weetumatowin to ask for this term. I have titled this section Ininisihcikewin, which one of the respondent interepreted as the way people managed community. The problem is that there are many different words for prayer and ceremony in the Cree languages. For example, Ayamihâwin is described as "prayer" (Okimasis, 2004; Ratt, 2016), yet the online Cree Dictionary mentions that there are themes of Christianity associated with "Ayamihâwin" (Miyo Wahkohtowin Education Authority, 2017). This meaning seems to 
align with the Okimasis (2004) and Ratt (2016) texts that mention the word Kâkîsimo "to pray traditionally" in addition to Ayamihâwin (Okimasis, 2004; Ratt, 2016). Jobin (2015) uses the word "Kiskinowâcihcika" to talk about ceremony. However, when I asked various Cree speakers about the differences between Ayamihâwin and Kâkîsimo, there are various opinions about the meanings of these words. There was a consensus that there is no generic term for ceremony, since all ceremonies have a specific purpose. This observation leaves me to wonder what was the specific term for political ceremonies, since there were specific political ceremonies based on the observations of the respondents. I do not know this word and further research would be needed to talk more in depth about the potential different words for various political ceremonies. For the moment, I am using the "Ininisihcikewin" to discuss ceremony because this word can be interepreted to be peoples' ceremony, and I have not found a suitable word to use that would refer to the specific political ceremonies of the Nehinuw.

Ceremony and prayer are central to the theory and practice of Nehinuw governance. Respondent 4: We saw that some of the traditional ceremonies came back and they had come back already from the First Nations organizational movement from the 1950s and we saw that in regards to starting meetings and moving on with that. And also speaking in Cree. The Elders wanted to make a point. They spoke in their own language.

From many of the discussions in this dissertation, prayer, and ceremony are integrated into the modern context to open and closed meetings.

Respondent 11: At all the meetings, they would open up with a prayer. They would pray for the guidance from the Creator. What did the Creator want from us? How 
is a Creator going to help us here? Decisions would never be about the immediate. Their decisions were always about the generations to come. It wouldn't be about what's happening today. It was more than that. It was for the future. For the children. When they're gone what will be left, you see? That's how they made a decision. It was futuristic I believe. Thinking about in the long run what will these generations be left with? But it was always one voice. And whoever that they chose to be the carrier of that voice, that's who that they would support. So praying and spirituality is very interwoven into governments. They said, we will not sign anything until we have prayer. So they lifted the pipes. That was their prayer. And they, the white people, I think they called it a peace pipe, eh. But it wasn't a peace pipe. You know, it, that Pipe to join you as one to make this agreement. But who, where does this smoke go? The pipe, that smoke, goes up to the Creator. They sat in a circle. So what they did was they made room like this. And there was one empty seat there and all the rest sat around like this. And the white people that were there said, like, to move. And they said, no. The Creator is sitting here. He's the one that's going to bind our treaties. So whatever you do, it's the Creator that will bind an agreement that will be the main voice that will keep whatever you agree to. So that's the difference, I think, in governance.

Ininisihcikewin is still relevant in contemporary organizations.

Respondent 8: Well if you go to say for example the Federation of Saskatchewan Indian Nations. How they conduct their business is primarily influenced by ceremony, pipe ceremony. But they usually leave the pipe there and maybe a staff 
or other cultural insignias, reminders of you know who we are and what we're all about and all that. And the Elders are sitting there, they're called senators over there and they have a responsibility there to, to add to the discussion and to the decision-making process.

Respondent 8 feels it is important to recognize the diversity of ceremony amongst Indigenous people.

Respondent 8: There's a lot of difference. I was a political advisor for the Assembly of Manitoba Chiefs about five or six years but you're dealing with at least four, maybe five different Nations, Dakota, Ojibway, Cree of course, Oji-Cree and Dene and each one has specific cultural understandings and even ceremony. So I had to learn quickly the differences so I could work effectively within that circle. So it goes back again to what I was taught by my Elders, the value of respect, respecting other people's rules for example, respecting other people's territory. The protocol would be when you go into a different area I would ask what are your rules that I should abide by.

Ininisihcikewin is important because it binds individuals to the past, to the collective, and to the Creator.

Respondent 11: In the traditional way of knowledge it's always, it's a collective. It's an agreement and it's also spiritual. When you're looking at indigenous knowledge it always reflects a Creator, a Creator as part of your decision-making. 
So that, to be that would be different from the way that it is governed now. You know, very different.

The Creator was a source of guidance that connected the past to the present and into the future. Ceremony and Prayer bind governance to the land, people, and our ancestors.

Respondent 11: Yeah. I'm, they're very much part of the, and, you know, spiritually, you, depending in what territory you're at, like, where we in the south we had our pipe ceremonies, right? So some people don't have pipe ceremonies but they're invited to that, to that circle. So you have, praying is very much, like I say, spirituality is very interwoven into governments. It's really definitely part of it.

I'll tell you an original story. You'll never read this in a book. And it has to do with Treaty 6, our original signatories. And I learnt this from a grandson of Chief Atakakop, he told me this story. He said when they were invited to sign in Fort Carlton, that's where they signed. They, all these, Chief Mistowasis and Atakakop and all these, the main Chiefs at that time they were all gathered. And they knew that this was going to be a long-term agreement. And they wanted, again, it was not for them. It was for the future, the children, the generations to come. It wasn't for them in that day. So they knew that. So when they came and they met the British people with all and I can imagine how intimidated they must have felt. They were given these jackets to wear, right? And these hats. And they had all these and this was they came with their clothes. But they were clothed as the people of that day in these government clothes. So but they insisted. They said, we will 
not, we will not sign anything until we have prayer. So they lifted the pipes. That was their prayer. And they, the white people, I think they called it a peace pipe, eh. But it wasn't a peace pipe. You know, it, that Pipe to join you as one to make this agreement. But who, where does this smoke go? The pipe, that smoke, goes up to the Creator. So what they did, Chief Atakakop and Mistowasis, they sat like this. They were all in the circle. So what they did was they made room like this. And there was one empty seat there and all the rest sat around like this. And the white people that were there said, like, to move. And they said, no. The Creator is sitting here. He's the one that's going to bind our treaties. So whatever you do, it's the Creator that will bind an agreement that will be the main voice that will keep whatever you agree to. So that's the difference, I think, in governance.

Ininisihcikewin is a key component to the operation of Nehinuw governance. In reflecting upon the role of Ininisihcikewin, I wondered if there were specific ceremonies for the operation of Nehinuw governance. As mentioned above, the Federation of Saskatchewan Indian Nations has used the Pipe ceremony to open their political forums. I searched for the translation of ceremony in the online Cree dictionary and 24 translations show up for ceremony and each references a different form of ceremony (Miyo Wahkohtowin Education Authority, 2017). Furthermore, I have experienced numerous ceremonies for numerous events. The Dene offer spruce boughs for safe travel across large lakes (Marchildon \& Robinson, 2015). Future research would be needed to explore the specific ceremonies of governance. 


\subsection{1 Ê-nametâcik (Land usage)}

Land is a central component of Nehinuw governance. In addition to several concepts used to describe the land, Kitaskinaw, Otênaw, and Ê-tetayan, there are specific land usage protocols. Ohcinêwin is a doctrine of Nehinuw law that influences the relationship individuals will have with nature. Ê-nametâcik translates to mean "they are making tracks" but refers to how the Nehinuw would use the land in relation to the future and other people.

Respondent 5: In the old days, people had winter camps. The families would have their own area that they considered their own area. One of the protocols is that Enametacik, if you saw signs of activity somewhere, you knew that that was somebody else's territory. You wouldn't cross the boundary if you saw that somebody has been leaving signs. So you stay within your own territory. That's one form of governance. There was nothing written. It was an understanding between families.

Respondent 5 made it clear that Ê-nametâcik was based on a common understanding between families and different communities. Knowing how to use the land and who was using the land was a key component of Nehinuw governance. Conservation was a key value for $\hat{E}$ nametâcik.

Respondent 5: They wouldn't necessarily shoot the first moose or the first deer. They would say something like 'save that for our grandchildren or our great grandchildren so they'll have something to eat too'. Same when they're berry picking. They won't pick all the berries. They say, 'Leave those for future generations'. 
E-nametâcik is a land usage protocol that refers to how the Nehinuw would use the land in relation to the future and other people.

Respondent 12: For example, if I was to go muskrat trapping in a certain lake where we live and where our trap lines are, [I] was taught from an early age to only harvest what you think the area can manage. So you always leave something for the next year. So you were taught how to do those things. If you were harvesting muskrats in a muskrat house you would initially you always get the bigger muskrats. And as you get those, if they get to be real small then you're harvesting the females. And then that was not good. So you always were told to make sure that you were keeping track of that. So you always were taught to be a manager of each trap that you had out there. So you were taught how to do those things so from an early point and it was done through language because all these little animals had names for that. So you were taught in that manner.

Community also had a role in Ê-nametâcik.

Respondent 8: But it doesn't take away the fact that this community made that rule, not just the Council but the whole community supported it. Another rule would be how we manage our lands for example. Back in the day we had process, you couldn't go just anywhere and start harvesting trees or minerals. You know minerals on the ground or medicines and stuff like that, you had to consult with the leadership and the Elders to help you determine which is the best area and how much you should take and what you should leave behind, that kind of stuff. 
The system of Ê-nametâcik (land usage) worked because the areas were maintained by families.

Respondent 12: So it worked, right, because all these areas were maintained by families. And each place that was maintained by a family was well run. And you can go throughout, in this particular place which is a large delta and ecosystem, it was working. And you can see that in historic records so you can see it.

I was raised to respect the environment and nature. At one point, I thought these were just the values of my family, but as I travelled to different Cree and Indigenous territories I have seen how important the land is to Indigenous people. Land as an abstract concept may not seem to be part of Nehinuw governance, but in discussions with the participants of this dissertation we see that $\hat{E}$-nametâcik is a fundamental principle of Nehinuw governance. We see concerns for future generations present in numerous elements of Nehinuw governance.

\subsection{Pâstâhowin (Consequences)}

Pâstâhowin refers to the consequences of breaking of political agreements or the breaking of laws against another human being (Borrows; 2010; Cardinal \& Hildebrandt, 2000; LaBoucane-Benson, Gibson, Benson, \& Miller, 2012; McAdam, 2015). However, respondents in this dissertation elaborated on a different understanding of this concept. Respondent 5 was the first to elaborate on the concept of Pâstâhowin.

Respondent 5: We have different ways of thinking. We have an idea like Pâstâhowin. If you deliberately are sacrilegious or go against sacred law, that's going to come back on you as well. So I know that because we view things in a 
more egalitarian way and they're seeing things in a hierarchical way, that could be a disadvantage to us, but because the land doesn't belong to us. We belong on the land where it's the white people think what people think you can own the land. There's a big conflict there. They need to keep that in mind and need to resolve some of these conflicts, [such as] the basic issues like land ownership.

In other words, Pâstâhowin is the form of law that deals with consequences. Respondent 6 elaborated on the consequences of breaking sacred law. The consequences were severe and held with high respect.

Respondent 6: Pâstâhowin has to do with some of things that was done. Pâstâhowin means to sin or to work against yourself. The consequences were Socheweyin, you suffered. You were taught those two principles. This is how to proceed with things. Those two principles would be taken into consideration. Because you know that if you don't do something, there's going to be consequences. I will give you an example. The consequences lasted for generations. The seven generations starts from your great grandparents to your great grandchildren, your great grandparents, your grandparents, your parents and you. See, I'm the fourth generation but I got my children, my grandchildren, my great grandchildren. If my grandparents didn’t teach me how to live then these other generations will suffer. Those are the consequence we call Pâstâhowin.

These two respondents talk about Pâstâhowin as the consequences of breaking agreements. For McAdam (2015), Pâstâhowin is part of a larger doctrine of Cree law that refers 
to offences against all creation. For LaBoucane-Benson, Gibson, Benson, and Miller (2012), Pâstâhowin could also be interpreted to be "overstepping the bounds, going outside the boundaries that you are entitled to" or "action of transgressing the boundaries of wahkohtowin" (p. 14). Based on my respondents and these sources, Pâstâhowin is a concept that outlines the consequences of breaking Cree law. In my follow-up discussions with my participants, one participant had an alternative understanding of Pâstâhowin. Pâstâhowin is closely connected with the idea of "sinning". Because of the connection to "sinning", the participants were unsure if Pâstâhowin was a Nehinuw or religious concept. There was no doubt that Ohcinêwin was a Nehinuw concept but perhaps with future research additional knowledge could be found on the connection of these two concepts.

\subsection{Reflection}

It was an honour to learn about my people. I thank them for sharing their knowledge on governance. There was so much knowledge shared with me during this process of Weetumatowin. Throughout this knowledge gathering, I was able to witness how the governance of our people worked during knowledge sharing. There were no disagreements between participants. Instead, there were moments of interpretation. Participants would respectfully dialogue with the knowledge. The knowledge is truly alive and contained in the language. In the next chapter, I analyze the implications of this knowledge using the Nistotên framework of analysis I outlined in chapter 3 to show how Weetumatowin on Nehinuw governance influenced my understanding of Nehinuw governance. I feel this dissertation is only just the beginning of my work for my people. Now that I have a deeper Nistotên (to understand) of Nehinuw governance, I would like to continue to expand this dissertation. I hope that this research is used by our communities to teach future generations about Nehinuw governance. 


\section{Chapter 5: Kinistotên? (Do you understand?)}

\subsection{Kinistotên?}

Nistotên is the Nehinuw verb meaning "understand" (Goulet \& Goulet, 2014, p. 216). The heading of this chapter is Kinistotên? In this form, the Nistotên is a question directed at a person. Do you understand? I am posing this question because that is the goal of this chapter. I want to prove to you that Ninistotên (I understand) Nehinuw governance.

Proving that you understand something is an interesting idea. Proof and knowledge creation are concepts central to the western education system. As I discussed in chapter 3, Indigenous people have different standards for proving knowledge. Proving and understanding within the Nehinuw worldview, center around the concept of Nistotên. I have deconstructed the process of Nistotên into three stages, experience, sharing, and understanding. Nistotên included learning from a variety of Nehinuw Elders and experts to learn their stories on Nehinuw governance. Using some modern technology and Nehinuw research principles and protocols, I feel that I understand Nehinuw governance. In the previous chapter, I shared the results of my dissertation centered around Nehinuw governance concepts that emerged during the dissertation. This chapter will discuss these results using the three stages of Nistotên: experiencing, sharing, and understanding. Using this framework, I want to prove to you that Ninistotên (I understand) Nehinuw governance.

\subsection{First Stage: Experience}

Being Indigenous is a political statement. However, growing up in Northern Saskatchewan, I thought I had very little exposure to Canadian Indigenous governance. I was raised on the land. My parents were not involved in politics. My mother was my teacher, and my father was a full-time athlete and hunter. My first political memories involve my family 
debating the qualifications of candidates in the local elections. I knew there were elections for local politics, Mayor and Council and Chief and Council. Many members of my family had been involved with politics. My great-uncle was president of the Métis federation. My grandfather was a key advocate to build a new bridge to my community. My uncle had been a local band Councillor. In a small community like Cumberland House, local politicians are family members and you frequently see them and hear gossip about local politics. Thus, my first understanding of Nehinuw governance was built on experiences of local municipal and Indian Act governance. Based on this initial view of governance, I felt that politicians had considerable influence and power. Furthermore, this influence and power was meaningful and incorporated Indigenous knowledge.

My first experience with governance outside of my community occurred after I won a scholarship to attend Lester B. Pearson College (PC) in 2000. The Member of the Legislative Assembly from my region, Mr. Keith Goulet mentioned my scholarship in the Saskatchewan Legislative Assembly (Legislative Assembly of Saskatchewan, 2000). I knew that Mr. Goulet worked in government, but I did not understand what he did. All the work of the provincial government seemed to occur far away in the provincial capital. The government seemed to benefit people from urban and farming communities. I had a strong dislike for farmers. I felt that they would receive government compensation and people from my community, mainly Indigenous, would not receive any government support. The key observation I gather from this experience was that local politicians were only a smaller part of a complex political system. I started to feel that local politicians were powerless to influence any policy change coming from the provincial capital. 
I attended my last years of high school at PC in Victoria, BC. At PC, I gained a deeper understanding of Canadian and World politics. PC is an international school with students from over 100 different countries. I would often find myself in discussions where I was the only Canadian present. I had to learn quickly about basic principles of Canadian politics, such as the role of the Prime Minister and the relationship between federal and provincial governments. I visited a nearby Federal penitentiary. This experience was my first experience with the Canadian criminal justice system. There were many different political events and discussions on campus that helped me to see that there were different leadership structures around the world. Additionally, talking with other international students helped me realize that there were diverse social and political problems around the world. Following the terrorist attacks of September 11, the Afghan students were concerned and fearful of the conflict on their territory. Many students would talk about war and conflict openly and jokingly. I recall one instance discussing sports with a student from Bosnia. The student joked that they had a rivalry with other local schools and that they always wanted to go and shoot the teachers from the other schools. I was naïve about the social and political realities of the world.

I was also naïve about people's perceptions of Indigenous people. Growing up in an Indigenous community, I did not know that we were a forgotten people. I perceived my upbringing, living off the land, to be normal. When I was thrust into this international environment at PC, I had to quickly learn about being Indigenous. At that time, I did not even know about the term Indigenous. People told me that I was Aboriginal. What does that mean and who has authority to decide my Aboriginalness? I knew that I was Cree, but I also thought that I was Métis since I had mixed ancestry. 
The international students seemed much more confident about their identity. I am Venezuelan. My independence day is July 5, 1811. I speak Spanish. But what are the "facts" about being Canadian or Aboriginal. I had to ask who am I? Discovering who I was, was a challenging and valuable experience. For example, on my second day at PC, I had to select my courses. All students were required to take two language classes. My first language was English, so I knew that English would be one of my language classes but what about the other. There was a system in place to allow students to take any language in the world. I was intrigued with the possibility of taking Nehinuw, but it turned out that this language system only existed if that alternative language was your first language. Since I was not fluent, I could not take a Nehinuw language class. This policy left me with two options. I could enroll in either French or Spanish. I had never taken either of these languages in school, so I decided to take Spanish. I filled out the course selection form and expected to start Spanish the next day. However, later that day I was called into the school director's office regarding my course selection. Apparently, PC had an additional policy that required Canadian students to take English and French. I did not want to take French, but I was told that there can be no debate on this issue since Canada is a bilingual country, all Canadian students must take English and French. This was the first time in my life that Canada's bilingual policy impacted my life. I protested this forced pedagogy, why did I have to take French? This bilingual narrative was unsettling. This debate forced me to think about Canadian identity for the first time. I realized that if bilingualism was the recognition of two founding nations, English and French, then I am not Canadian. In the end, I was forced to take French. I realized that Canada is not an Indigenous nation; it is a colonial state based on assimilation and bilingualism, which completely ignores Indigenous people. Since that moment, I have never celebrated or participated in the colonial narrative of Canada. 
For example, I have never voted in a federal election because I felt that to participate in Canadian democracy was to accept this colonial narrative.

The policies at PC helped me to see the impact of ongoing colonization. The simple act of being forced to take French started me down a path that helped me appreciate my Indigenous heritage. As one of two Indigenous students at PC out of 200, we had to represent all Indigenous people on campus. I often met resistance about my heritage and the history of my people. In one instance, while I was sharing a story about my life, a student called me a liar. She claimed that the life I described did not exist. None of the other Canadian students present at that conversation supported me, I was ashamed by her claim. I thought maybe there were something to her critique, but I knew that I was not lying. For the first time, I realized that being Indigenous was a unique experience, and despite the reaction I was proud of my heritage. I knew I was not lying because I could see my territory every time I closed my eyes.

Following PC, I attended Simon Fraser University (SFU). Two fundamental events occurred while I was at SFU. First, I became Nehinuw, but this did not occur immediately. When I began my studies at SFU, I continued to try to socialize with international students. I felt very international having just graduated from PC, an international school with representation from 100 countries, and I wanted to be international because I no longer felt Canadian. I tried to socialize with the international students, but I was never accepted by the international community. At that time and by accident, I started to participate in the First Nations Student Association. One day, I was shopping off campus when an Indigenous student from SFU saw me and asked where I had purchased my food. With both hands full of groceries, I turned and pointed with my lips to the store. The student laughed and said, "you must be Cree from Saskatchewan or Manitoba, only the Cree from there point with their lips". This moment, which 
seems so mundane, was pivotal to my development as a Nehinuw man. For the first time, outside of my community, someone recognized and accepted me for who I was. This student, Wayne Nipshank, became my best friend at SFU, and the other students at the First Nations Student Association became my family.

The second significant event to occur at SFU was I became interested in politics and started down an education path that has led me to a Ph.D. in Policy Studies. In my first politics class, a casually dressed man walked to the front of the lecture hall and announced that class was cancelled. The packed auditorium of around 500 students started to leave. After ten minutes, when the class was nearly empty, the same man walked back up to the front of the classroom and said, "Hello. My Name is Professor Andrew Heard. I am the instructor for this course. When I came down here at the beginning of class, why did nobody question my authority to cancel class? What is authority and power? How do we decide who gets authority and power? In political science, these are the central questions we try to answer." After this demonstration, I was hooked on political science and I wanted to answer those questions. I wanted to apply those questions to my lived experiences. Why did I have to take French? Why did my peers not believe me about my upbringing as an Indigenous person? Why did I feel different from the other Canadians? What does it mean to be Indigenous?

Because of a desire to answer these questions, I decided to major in political science with a focus on Canadian politics. As I progressed through this degree, I found myself increasingly interested in Canadian Indigenous politics. My knowledge in the topic expanded as I met and interacted with Indigenous people from across the country. I relearned the history of Canada. I realized that Indigenous people, while sharing common experience of colonization, were extremely diverse. I grew up thinking there were Cree, Chipewyan, White, and everyone else. 
At SFU, I realized Chipewyan was a negative term. Furthermore, I met Salish, Coast Salish, Haida, Chilcotin, Alberta Cree, Urban Indians and Indigenous people from many other nations. During this enlightenment period, I went home one summer to visit my family and participate in community events. One of these events was a canoe race. My home community, Cumberland House, has a long historical connection with canoeing (Marchildon \& Robinson, 2015). In this canoe race, there was prize money based on a two-tiered prize structure, open and local. The open category applies to any team and the local applies to anyone that is from the area. My father and I ended up winning the canoe race, meaning that we won both the open and local prize categories. At the award ceremony, my father and I did not receive the local prize. The reason for this discrepancy was never made clear, but it seemed that they made this decision for one of two reasons. First, our home, which is located 50 kilometers in the traditional territory of the community, is not actually in the community. Second, we were neither status Indians nor band members of the Cumberland House Cree Nation. In any case, this denial was the first time I had experienced identity politics and the impact of the Indian Act. My father and I were denied a local prize because we were not viewed as local. This experience left me wondering about Nehinuw identity. I experienced the impact of the colonial legacy of Canadian Indigenous policy that has made specific categories of Indigenous people, Aboriginal, Status, First Nation, Métis, and has erased Indigenous citizenship law.

This experience stoked my interest in Indigenous politics. I wanted to pursue a career in Indigenous politics to address the many issues I had learned about in my undergraduate education and experienced throughout my life. I felt the best option to pursue this goal was a career in politics. At that time, my view of politics had been shaped by the lived experiences and my recently completed political science degree. I felt that if I wanted to change Indigenous 
politics, I would have to become an elected representative of the community. However, I found myself wanting to learn more about governance before committing to the career of an elected representative, so I thought the best way to achieve this goal would be to enroll in a degree that focuses on public policy. I was interested in the behind the scenes activities of government.

After I finished my degree at SFU, I enrolled in the Johnson Shoyama Graduate School of Public Policy (JSGS) to study public policy. I wanted to learn how to influence public policy because I wanted to change Canadian Indigenous policy. The program at JSGS helped me gain both a deeper theoretical and practical understanding of Canadian public administration. I began by learning about the theoretical foundations of Canadian governance. I learned about the complex and overlapping structure of Canadian governance. For example, I analyzed the written and unwritten interactions between the three branches of Canadian government, judicial, executive, and legislative (Inwood, 2012; Malcolmson, Myers, Baier, \& Bateman, 2016). In addition to assessing the role of these branches, I evaluated the interactions between the levels of Canadian federalism. What is the relationship between federal, provincial, and municipal governments? I learned about the theory of governance. I was drawn to the idea that governance is more than what governments do that governance can occur outside of the state. Pal (2010) describes governance as "the process of governing or steering complex systems in cooperation with a variety of other actors" (p. 37). Bevir $(2010,2012)$ notes that governance started to emerge when academics recognized that the role of the state had decreased. Instead of governments being at the centre of governance, there are many non-state actors invested in governance. As I learned more about the theory of public administration, I realized that there are several challenges for this state-centered Weberian model of Canadian governance. For example, the actors of governance have shifted and diminished the role of the state (Bevir, 2012; Evans \& 
Shields, 2010; Pal, 2010; Stone, 2008), and policy-making is not a linear process, rather a dynamic interaction between choices, problems, solutions, and participants (Cohen, March, \& Olsen, 1972). Based on my experience in Canadian governance, the hierarchy and division of power is real. Ministers have the power and authority to follow or reject the policy advice of the senior administration (Malcolmson, Myers, Baier, \& Bateman, 2016). Additionally, the decisionmaking theories of public administration face the most limitations. Objectivity and rationality are the most challenging concepts to accept. Many of the models that are discussed in public administration, such as bounded rationality or the Garbage Can model, assume that decisionmakers are objective and rational. While many bureaucrats strive to be objective and rational, I do not believe that objective and rational policy-making is possible. The issue with this lack of objectivity and rationality is that this gives considerable power to the administration. Since Canadian governance only has the time and resources to seriously consider a few options on any policy issue, policy-makers have significant power within Canadian governance.

The JSGS program also gave me valuable practical experiences. During JSGS, I was exposed to representatives from various government institutions, policy process and public administration literature, economics of policy making, tools of policy analysis, and assignments designed to give students a better understanding of theoretical and practical governance, such as policy evaluation. This knowledge was reinforced during a post-degree internship with the Saskatchewan government. The internship was an executive internship program in which I shadowed the Minister and Deputy Minister of the Saskatchewan Ministry of Advanced Education, Employment, and Labour. In my executive internship, I experienced the power and authority executive decision-makers have within the legislative and executive branches of Saskatchewan provincial government. The Premier has the prerogative to select the executive 
members of government. The executive members of government form the cabinet. Through these executives, the Premier oversees the day-to-day business of government. Members of the cabinet are often the Ministers of specific departments of government. Ministers are decisionmakers in Canadian governance. While the Ministers are autonomous, the Premier, with some degree of variation between leadership style, has final control over the decisions of departments (Blakeney \& Borins, 1998). For example, some Premiers may have a controlling leadership style and prefer to review the policy decisions of their Ministers. In most cases, Ministers make independent policy decisions except in specific policy areas that are of interest to the Premier. Furthermore, even if you are not the Premier, the Ministers work with the senior managers of the bureaucracy to run their departments. Every ministry is organized slightly different, but government is structured and runs as a Weberian bureaucracy. In the Ministry I worked for, the hierarchy had established a Deputy Minister, two Assistant Deputy Ministers and one Associate Deputy Minister. The structure of government continues to divide under the Deputy Ministers into program directors, administrators, program officers and so on. Within this hierarchical organization, orders are passed down, policy is passed up and policy is made. The internship provided the perfect resolution to the JSGS program; JSGS gave me the foundational theoretical knowledge of public administration, and the internship exposed me to the practice of provincial policymaking.

Considering the theoretical and practical knowledge I gained in the JSGS program, the practice of Canadian governance operates very closely to the theoretical explanation of Canadian governance. I experienced a traditional view of public administration that sees governance as the process of why, when, who and what of how law, legislation, and policy are formulated, designed, implemented and evaluated (Birkland, 2011; Frederickson \& Smith, 2003; Inwood, 
2012; Kernaghan \& Siegel, 1999; Waldo, 1948). I saw public policies, which are a government's “course of action designed to help a public problem" (Birkland, 2011, p.230), formulated around specific problems. I witnessed discussions that decision-makers had on the types of policy tools available to address specific problems such as the implementation of constitutional, statutory, regulatory, operating procedures, patterned behavior and subtle changes (Birkland, 2011).

At the same time, I experienced several situations that challenged the traditional views of public administration. I witnessed bureaucrats that had a heavy influence on the direction of policy change, which challenges the linear hierarchy of Canadian governance. I experienced the influence of power and authority between the Premier and Ministers, Ministers and Deputy Ministers, and the state and society. Finally, I started to realize that the challenges faced by Indigenous people are created by the Canadian Indigenous governance framework. For example, the 1867 Canadian constitution erases Indigenous governance authority and delegates responsibility for Indians and Indian lands to the federal government. While the more significant impact was the erasure of Indigenous governance authority (Ladner, 2005), the Canadian Indigenous governance framework creates an unnecessarily complex policy regime. Instead of recognizing that Indigenous people have the right to self-determine their future, the Canadian Indigenous governance framework is paternalistic and requires unnecessary interdepartmental and intergovernmental cooperation. Because of this jurisdictional challenge, there have been numerous failures. For example, Jordan's Principle, the result of the federal and provincial government to agree on the provision of its Constitutional and Treaty obligation, was designed to provide a template for the federal and provincial government to provide adequate health care, but the government has continued to avoid this principle (Blackstock, 2012; Canadian Human Rights Tribunal, 2016; Palmater, 2011b). 
My real education on Indigenous governance did not begin until I was well into my doctoral studies. For my final Ph.D. course, I enrolled in Dr. Pamela Palmater's Indigenous governance class. At one point in the class, when we were analyzing the Indian Act, I realized that everything I had learned was Canadian Indigenous governance. I homogenized two visions of governance for my entire student career. I was finally asking myself what Indigenous governance is in Indigenous terms. Canadian Indigenous governance is the study of a branch of Canadian government. Section 35 is a section of the Canadian constitution. The Indian Act is an act of Canadian government. If I wanted to truly to understand Indigenous governance, I needed to discuss Indigenous governance in Indigenous terms. Furthermore, as I reflected on the diversity of Indigenous people, I realized that Indigenous governance does not go far enough to represent the diversity of Indigenous nations and complexity of Indigenous governance. Critical Indigenous governance research supports diversity yet not enough explores the complexity. With that inspiration in mind, I designed my dissertation to explore Nehinuw governance in Nehinuw terms because I wanted to understand Nehinuw governance.

What does Nehinuw knowledge teach us about Nehinuw governance? Nehinuw governance should be considered with more respect and diligence. To truly understand Nehinuw governance, we need to rethink fundamental concepts such as governance, authority, decisionmaking, and leadership. I will begin by discussing how and why we need to reconsider the concept of governance. Governance scholars note that governance is a complex process which increasingly focuses on non-state actors (Bevir, 2010, 2012). For example, Pal's (2010) description of governance as "the process of governing or steering complex systems in cooperation with a variety of other actors" (p. 37) centres around the role of "other actors" in this case non-state actors. The complexity of Nehinuw governance is created not by the interaction 
between actors rather by the interaction of legal systems. When I would ask, what is Nehinuw governance, there was no specific answer because respondents could not directly translate governance. Instead, the idea of governance had to be translated. The result of this translation was that respondents identified several Nehinuw legal systems including Ohcinêwin (law of the land), Pâstâhowin (consequences), Wahkohtowin (law of social relations), Wânasiwayin (law making), Ê-nametâcik (land usage), Okimâwiwayin (leadership law), and Kiwicîtowek Insiniwuk (working together). Since Figure 1.1. Interconnection of Nehinuw legal systems participants identified and discussed various Nehinuw legal systems, this led me to ask about the relationship between these legal systems. Each of these legal systems are separate, yet they are also interconnected. See figure 1 for image depicting the

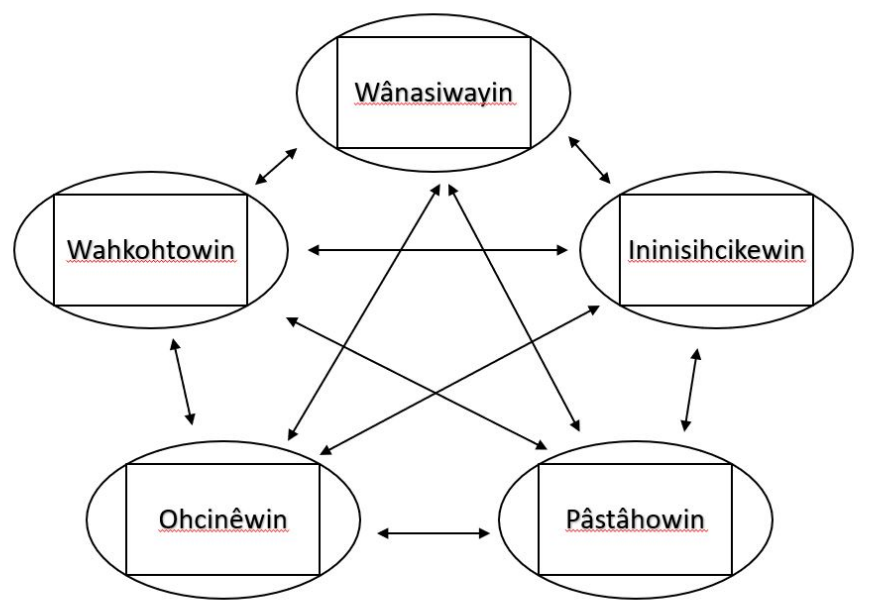
interconnection.

For example, Wahkohtowin is the Nehinuw legal system that focuses on family and social relationships. However, in the literature Wahkohtowin is the "overarching law governing all relations" (Borrows, 2010, p. 84) and extends to relationship with the land (Jobin, 2014). If Wahkohtowin includes relationships with the land, then what is the purpose of Ohcinêwin (law of the land)? Furthermore, respondents also identified the concept of Wânasiwayin, which was translated as law, setting rules for ourselves, to set things right, laws that govern yourself, rules to live by, and making laws. These Nehinuw legal systems are connected and operate in their own. Napoleon's (2007) characterization of Indigenous legal systems as legal orders, which describes 
law "that is embedded in social, political, economic, and spiritual institutions" (p.2), applies to Nehinuw governance. I interpret Napoleon's legal order description to mean that there is the potential for multiple legal systems to co-exist, and I argue that to understand Nehinuw governance, it is necessary to understand each of these legal systems.

I was not able to compile a definitive list of Nehinuw legal systems nor was I able to thoroughly analyze one of these legal systems. I did not expect that Nehinuw governance would be so complex and diverse. In future research, I would like to continue to explore the legal orders of Nehinuw governance. As stated previously, respondents identified seven principles, Ohcinêwin (law of the land), Pâstâhowin (consequences), Wahkohtowin (law of social relations), Wânasiwayin (law making), Ê-nametâcik (land usage), Okimâwiwayin (leadership law), and Kiwicîtowek Insiniwuk (working together) that provide theoretical and practical insight into the internal governance of the Nehinuw. A future project could look at the similarities between Nehinuw nations and other Cree nations. For example, Darcy Linklater (as cited in Pratt, Bone, $\&$ The Treaty and Dakota Elders of Manitoba, 2014) discusses twelve principles of Kihche'othasowewin (the Great Law). Mr. Linklater is from a group of Cree people that live further north. Is there a similar great law for the Nehinuw? Furthermore, this dissertation looked specifically at the governance of the Nehinuw, but what of the International Nehinuw governance theories represented by the Treaties. How does international treaty theory continue to influence Nehinuw governance?

The second way we need to rethink Nehinuw governance is in terms of its authority. There is no central Nehinuw political institution. Nehinuw governance has multiple actors that originates with the family and extend outwards. Nehinuw governance gradually expands outwards as individuals interact with other families, communities, and nations. In other words, 
there are multiple actors in Nehinuw governance, and the application of Nehinuw governance starts with the family and expands outwards. At the smallest level, specific territories are managed by families. These territories were referred to as Ê-tetayan. Seasonally and through Canadian policy, Otênaw (communities) became gathering places for families. At the broadest level, territory was referred to as Kitaskinaw, which is translated as our land. Nehinuw land usage has changed overtime to include Askonikan (Reserve).

Governance is not thought of in relation to the Nehinuw state, Nehinuw governance occurred in families, communities, and in the territory. At one time, land usage was much more significant, and governance occurred out on the land and in the specific Ê-tetayan (family territories). Thus, Nehinuw governance has dynamic sources of authority that exists in multiple actors. Nehinuw governance could occur between two families in an isolated place on Nehinuw territory or it could occur in Otênaw. Eventually, Nehinuw governance would reach borders of Kitaskinaw. Borrows (2002) discusses how law is applied in increasing levels of influence. Similarly, Cardinal and Hildebrandt (2000) discuss how Wahkohtowin (the laws governing all relations) and Miyo-wîcêhtowin (the laws concerning good relations) influence relations outside of the family and between communities and nations. My participants all discussed how they would learn the values of Nehinuw governance within their families and these values would influence how they interacted with the world. Nehinuw governance begins with people looking after their own territory. As families interacted with other families or moved near each other, they formed communities and eventually expanded outwards to the larger territory.

Another way we need to rethink Nehinuw governance is in terms of its decision-making practices and theories. Decision-making in Nehinuw governance is both a practice and a theory. For example, there are several Nehinuw concepts that refer to how communities worked together 
including Kiwicîtowek insiniwuk (working together), Mamikwaytomatowin (community consensus), Mâmawi-wîcihitowin (working together), and Wekokumowin (asking people to come out to a debate). Community is both a physical location and decision-making method. Everyone in the community worked together for the common good. This philosophy is represented by the Kiwicitowek insiniwuk theory. In addition to Kiwicitowek insiniwuk, significant efforts were made to include everyone in the community on all decisions. Mamikwaytomatowin is the Nehinuw equivalent of consensus-making.

Additionally, Nehinuw governance has unique leadership theories and practices. There is a special role for Kihtêyak (Elders), Okimâw (leaders), and Simâkanis (spiritual leaders). Kihtêyak were looked to as sources of knowledge and guidance. Okimâw were recognized for their experience. Simâkanis had a specific role as community warriors. In combination with Nehinuw decision-making theory, Nehinuw governance operates on an intricate balance between individual and collective concerns. This balance adds an interesting perspective on power and authority. Nehinuw governance balances collective voice with expert knowledge. Being a Kihtêyah (an Elder) is more than being an old person; it requires the collective recognition of your community based on an Individual's knowledge and skills. Being an Okimâw requires a similar level of recognition and knowledge. Clearly, Kihtêyah and Okimâw have considerable power and authority within Nehinuw governance, yet they are not dictators. Community decision-making protocols require input from the entire community.

Finally, the oral traditions of the Nehinuw provide specific protocols for the dissemination of knowledge in Nehinuw governance. As one participant noted, the Nehinuw have multiple narrative frameworks. Furthermore, there are specific protocols for referencing material within the Nehinuw oral tradition. I focused on the narrative framework of 
Weetumatowin, but is Weetumatowin the most appropriate framework. Is there a specific framework for Nehinuw governance and law? How should we include dreams within governance? Furthermore, Ininisihcikewin (people's ceremony) is critical to the Nehinuw worldview including governance. Are there specific governance ceremonies? Âcimowin (stories), Ininisihcikewin (people's ceremony), and the other principles discussed in this dissertation have been incorporated into contemporary governance practices. Further research would be needed to explore the specific protocols of Kiwicîtowek Insiniwuk, Mamikwaytomatowin, Mâmawi-wîcihitowin, and Wekokumowin. Were there specific narrative forms or ceremonies for each of these components of Nehinuw governance? For example, what were the specific protocols of those debates and narrative forms, such as Wekokumowin (asking people to come out to a debate), and how did that impact the decision-making? The more I learned about Nehinuw governance, the more questions I had, and I want to explore these during my career.

In summary, Nehinuw governance challenges us to rethink fundamental concepts such as governance, authority, decision-making, and leadership. Nehinuw governance is the dynamic interaction between multiple legal orders such as Ohcinêwin (law of the land), Pâstâhowin (consequences), Wahkohtowin (law of social relations), Wânasiwayin (law making), $\hat{\mathrm{E}}$ nametâcik (land usage), Okimâwiwayin (leadership law), and Kiwicîtowek Insiniwuk (working together). The authority of Nehinuw governance starts within the family and gradually expands outwards from Ê-tetayan (family territories), Otênaw (communities), to Kitaskinaw (territory). Nehinuw governance has complex decision-making theories and practices. Theoretically, Nehinuw governance has rigorous community decision-making protocols including Kiwicîtowek Insiniwuk (working together) and Mamikwaytomatowin (consensus making). Practically, 
Kiwicîtowek Insiniwuk (working together) and Mamikwaytomatowin (consensus making) meant that there were specific roles for leaders, Elders, and experts. Finally, there were specific ceremonies and procedures for Nehinuw governance. Thus, I feel that Nehinuw governance is considerably more complex than Canadian governance because Nehinuw governance balances community, spirituality, and leadership. This model of governance continually balances the past, present, and future.

\subsection{Second Stage: Sharing}

I began this stage of Nistotên after I had reviewed all the Weetumatowin discussions and completed a first draft of the previous section. I had four face-to-face and three phone conversations that lasted between thirty minutes and one hour. These discussions took place December 2015 and June 2016. No additional knowledge was collected during these discussions. Participants were excited with the progress of this dissertation. These additional discussions helped me refine the translation and spelling of the key terms used in this dissertation. For example, in these conversations I asked participants about the role of Elders in our language. There were some interesting discussions around the correct terminology for Elder. In the Nehinuw language, there are two common terms used for Elder. Kihtêyah (an Elder) and Kiseniniw (old person) are two common terms used in the language. The difference between these two terms is that Kiseniniw simply describes someone that is old, whereas Kihtêyah is the correct terminology used to refer to an Elder.

\section{$5.4 \quad$ Third Stage: Understanding}

The understanding stage of my analysis took place in three community engagement events between February and May of 2017. There were only positive comments based on my presentation. In each case, I was invited back to the community to work with local educators and 
Elders to further discuss this knowledge. In the Northern Village of Cumberland House, I was invited back to work with local educators and to present to the high school. The Cumberland House Cree Nation invited me back to talk about the topic of my dissertation at their annual summer cultural camp. Opaskwayak Cree Nation invited me to present to youth at the local high school and to work with their local Elders council. I continue to maintain contact with all my community contacts and I expect to be working with these communities in the future. In total, I received feedback from 24 community members during this state of my research.

\subsection{Ehe, Ninistotên}

I feel I can say Ehe, Ninistotên (Yes, I understand) Nehinuw governance. The process I used to Nistotên Nehinuw governance was achieved by honouring the worldview of my ancestors and with the help of modern technology. I honoured my ancestors by using the Nehinuw worldview as the basis for the theoretical framework of this dissertation. I began by kiskinaumasowin (teaching myself) about the literature on Nehinuw and Indigenous governance. During Kiskinaumasowin, I realized that past research had not covered Nehinuw governance in Nehinuw terms, and I designed this dissertation to address this issue. I then proceeded to design this dissertation around Weechihitowin, how the Nehinuw educate themselves. The first key component of the Weechihitowin is a commitment to experience and oral history. I used the Weetumatowin narrative framework to understand Nehinuw governance from several Nehinuw Elders and experts. I also had to make a commitment to learn from experience. I embedded the commitment to experience by following the procedures of Nehinuw Nistotên (understanding). Specifically, I focused on how my understanding of governance shifted during this dissertation.

What is my understanding? I realized in the first interview that governance does not directly translate into the Nehinuw language, but that does not mean that the Nehinuw people did 
not have governance. In fact, what started to unfold during Weetumatowin (knowledge gathering) was that I started to realize that Nehinuw governance is extremely dynamic and that the complexities of Nehinuw governance challenge a simplistic and homogenous view of Indigenous governance. Nehinuw governance requires an understanding of multiple legal orders, incorporates multiple sources of authority, implements decision-making theory and practices, and utilized multiple protocols and ceremonies. One dissertation cannot address the complexities of Nehinuw governance. I could pursue a dissertation on each of the Nehinuw theories and practices I identified in this dissertation. Despite all the potential areas of research, I feel that I have answered the central research question of this dissertation, which is what does Nehinuw knowledge teach us about Nehinuw governance, by showing that Nehinuw governance is complex and diverse. The theories and practices of Nehinuw governance are alive and held by knowledge-keepers. At the same time, the knowledge is threatened, and this dissertation is only my first step to try and help the protection and revitalization of Nehinuw governance. I hope that this chapter shows that I am beginning to understand Nehinuw governance. This research is just the beginning for future discussions and education on Nehinuw governance. In the next chapter, I will identify several ways I would like to continue the work started in this dissertation. 


\section{Chapter 6: Miskâsowin (Finding yourself)}

\subsection{The Knowledge is Alive}

A dissertation is meant to be a scholarly journey in which the student establishes themselves as an expert in a specific topic. I feel that I have done more than that in this dissertation. This dissertation was a scholarly and personal journey. I have found my sense of origin during this dissertation because of this awareness I have titled this chapter "Miskâsowin". Miskâsowin is a Cree concept that refers to finding one's sense of origin (Cardinal \& Hildebrandt, 2000). I found my sense of orgin in many important ways. I learned the knowledge of my people. I learned about the history of my people. I made new relationships with people in my territory. I became part of the future of my people. I explored a topic that has always interested me. This dissertation has been one of the most rewarding experiences of my life. In closing this dissertation, I want to reflect on what I have learned. More importantly, I want to show you why this knowledge is useful.

I want to go back to something that happened to me at the beginning of this dissertation. When I started my Ph.D. in 2011, I was a teaching assistant for a Canadian politics class. I was excited to interact with students and to work with an accomplished professor. Midway through the semester the professor mentioned that he was going to talk about the fur trade. He told me about the historical and economic perspective he was going to take in class. I was interested to hear his lecture on the fur trade. I grew up on a trapline, and I had a growing interest in the politics and economics of the fur trade. When it came time for class discussion, students were not as keen as I was on this topic. Yet, when I told people that I grew up in the fur trade, the class atmosphere changed. The room went silent. Eventually, a student raised their hand and commented that they thought the fur trade was ancient history and that Indigenous people were 
also ancient history. I was shocked to find that many of the students in the class had similar opinions about Indigenous people. In fact, as we discussed Indigenous people I found that most of the people in the class had stereotypical ideas about Indigenous people.

The one stereotype that stuck in my mind was the idea that Indigenous people are a people of the past. I knew there would be some sterotypes but Indigenous people in the past? I should not have been that surprised since I had witnessed this lack of understanding numerous times throughout my life. One time, one of my peers called me a liar after I explained my life in the woods, living off the land. Another time, a university professor commented why should we study Indigenous people. Now that I have completed this dissertation, designed to further our understanding of Indigenous knowledge, I am more convinced than ever that Indigenous knowledge is alive. One of the biggest challenges facing the decolonization of Indigenous governance centres around the state of this knowledge. To what extent has knowledge of Indigenous governance been impacted by colonization (Porter, 2005). The underlying question in Porter's work asks, is there a source of "pure" Indigenous knowledge on governance? Somewhat pragmatically, Porter asks how relevant a body of "pure" Indigenous knowledge on governance would be considering the changing values in contemporary Indigenous society.

I do not have the answer to these questions, but we need Nistotên (to understand) Indigenous knowledge before it is lost. Being Indigenous, I had long taken for granted the survival of Indigenous knowledge. Simply being alive does not ensure that our knowledge will survive. We need to act to protect and revitalize our knowledge. Indigenous knowledge is hanging by a thread. For 150 years and centuries prior, settler societies have tried to assimilate and eliminate our knowledge and existence. There is an African proverb that captures the potential impact assimilation has had on Indigenous knowledge, when an Elder dies a library 
burns (Grenier, 1998). In the Canadian context, this proverb is more threatening because colonization targets Indigenous people. Since our Elders have been displaced, abused, and murdered, our knowledge is severely threatened. I know this because I have heard our Elders, Elders that I perceive to know it all, lament that knowledge has been lost. These Elders feel that the past generation lived a more authentic lifestyle than themselves. The Elders in my grandparents' generation spoke a higher form of Nehinuw. They lived exclusively on the land. My great-uncle Roger Carriere told me that he did not see a car until he was 8 years old. My grandfather once showed me the tree he was born under. I have witnessed the loss of Indigenous knowledge. One time when I was out on the land with my father, we caught a juvenile sturgeon. He said the name for the juvenile sturgeon is Okasustay-namaysis ( a sharp pointed little sturgeon). He commented that this word is no longer being used because the sturgeon population has collapsed. The Nehinuw people once had a detailed vocabulary to describe the sturgeon, considering the sturgeon were the staple summer food for our people, however we have lost the sturgeon vocabulary because we no longer rely on the sturgeon. I heard many stories like this one about the loss of our knowledge. Words and ideas that have been lost over time. I am a part of this story. I am not fluent in the Nehinuw language. These stories inspire me to protect Nehinuw and Indigenous knowledge. If we do not use these words, the knowledge will be lost. There are many types of actions needed to protect and revitalize Indignous knowledge. In chapter 2, I discussed five resurgence strategies including resistance, control, internationalization, ideational, and indigenization. I was inspired to explore Indigenous governance in Indigenous terms in this dissertation, specifically through the lens of the Nehinuw people, because I want to indigenize the field of governance. I feel like I have only really started my education on Nehinuw governance during this dissertation. The concepts in this dissertation 
are the beginning of my education on Nehinuw governance and my life's work. When I began, I had only heard some of the words shared with me during this dissertation, now through the process of Nistotên, I feel that I am beginning to understand the theories and practices of Nehinuw governance. In closing this journey, I want to discuss what I have learned by addressing four lingering questions: who are the Nehinuw, what is Nehinuw research, what is Nehinuw governance, and what is the future of Nehinuw governance? My discussion of these questions will show that I answered my central research question and made a unique contribution to the fields of Indigenous governance and methodology.

\subsection{Glossary of Nehinuw Governance Theories and Practices}

Before I discuss the results of this dissertation, I want to share a list of Nehinuw governance theories and practices that I compiled during this dissertation. This glossary is not a definitive list of Nehinuw governance theories and practices. It is designed to be a document that can be used and edited by the community. I have shared this glossary in an electronic format (.doc) with the involved communities so the communities can edit the glossary to include additional terms. I envision this glossary being used as an educational tool to teach youth about Nehinuw governance theories and practices. I have made myself available to work with local education practitioners to develop these tools. For example, when I shared this dissertation and glossary with the involved communities, there was an overwhelmingly positive response to this dissertation. Potential ideas included presentations and discussions at future cultural camps, presentations to senior students in high school, and the development of a series of Nehinuw governance language posters for display around the local schools and communities. I would also like to pursue research funding to continue this work with additional Nehinuw communities. 
The terms in this glossary were identified by one or more participants of this dissertation. I expand on many of these concepts in chapter 4. I only expand on concepts that were explained by participants during Weetumatowin. For example, I have a section on Âcimowin (storytelling). I have a section on Âcimowin because there were several stories that discuss the role of Âcimowin in Nehinuw governance. I do not have a section on Aski Kanache Pumenikewin because this concept was only mentioned in passing as a concept in another source during one conversation. Secondary discussions with my research participants helped refine the concepts so that they were consistent with the Nehinuw language. This document uses standard roman orthographic spelling. Variations may be used if the word has been specifically used in a written document.

Table 1.1. Glossary of Nehinuw Governance Theories and Practices

\begin{tabular}{|l|l|}
\hline Âcimowin & $\begin{array}{l}\text { Telling significant stories, can be used to support decision- } \\
\text { making }\end{array}$ \\
\hline Aski Kanache Pumenikewin & A person must protect the land. To take care of things \\
\hline Askonikan & Reserve but also land saved for Indians. \\
\hline Atotumowin & A form of narrative that looks back to past events. \\
\hline Ayatotaman tahatotum & $\begin{array}{l}\text { Narrative form that discusses past events to inform current } \\
\text { discussions. }\end{array}$ \\
\hline Ê-nametâcik & Land usage protocol based on use of land. \\
\hline Ê-iskopitat kistekan & Depth of a plow in reference to treaty promises. \\
\hline Ê-tetayan & Family or traditional territory \\
\hline Ethinesewin & $\begin{array}{l}\text { Traditional knowledge, there is a duty to respect and seek. } \\
\text { Self-determining respect. }\end{array}$ \\
\hline Ininisihcikewin & $\begin{array}{l}\text { Literally 'Peoples' ceremony". Cree law in connection to } \\
\text { governance. }\end{array}$ \\
\hline Kanatethechikewin & $\begin{array}{l}\text { People must act in accordance to law. Guardian/keeper but } \\
\text { when it is done properly. }\end{array}$ \\
\hline Kiwicitowek Insiniwuk & Working together as a community. \\
\hline Kiche-sepemacowin & $\begin{array}{l}\text { The way you make a living, connected to the interaction of } \\
\text { individuals. }\end{array}$ \\
\hline Kiche-etosowin & $\begin{array}{l}\text { The way your culture interacts with the environment, an } \\
\text { interaction between the land and people. }\end{array}$ \\
\hline Kiche'othasowewin & Code of twelve laws and principles. \\
\hline Kichi-wansoy & The main lawmaker like a Judge. \\
\hline
\end{tabular}




\begin{tabular}{|c|c|}
\hline Kistethichikewin & $\begin{array}{l}\text { The conduct of a person must be based on the sacred } \\
\text { responsibility to treat all things with respect and honour. }\end{array}$ \\
\hline Kitaskinaw & Your land. Used to refer to a specific territory. \\
\hline Kwayaskonikiwin & $\begin{array}{l}\text { The conduct of a person must be reconciled with the great } \\
\text { law. }\end{array}$ \\
\hline Mamikwaytomatowin & Community consensus dealing with common issues. \\
\hline Mâmawi-wîcihitowin & Working together. \\
\hline Newa-matocin & Seven teachings. \\
\hline N'totumakewin & $\begin{array}{l}\text { A person must first seek to understand. A duty to teach, } \\
\text { understand, share, and seek traditional knowledge. Listening } \\
\text { carefully to other people. }\end{array}$ \\
\hline Ocênas & Small Communities. \\
\hline Ohcinêwin & $\begin{array}{l}\text { Meaning breaking of law against another other than a human } \\
\text { being or to sin. }\end{array}$ \\
\hline Okimâkan & Indian Act Chief or a pretend boss. \\
\hline Okimâkanuk & Indian Act councilors still reference to pretend. \\
\hline Okimâw & Chief. \\
\hline Okimâwiwaywin & Leadership rules. \\
\hline Onesewaynesuk & Community rules. \\
\hline Onesewaynyuk & People that make laws. \\
\hline Onesewaywin/Wânasiwayin & $\begin{array}{l}\text { Law making or making laws. Law derives from the verb "to } \\
\text { set things right". }\end{array}$ \\
\hline Otênaw & Smaller family territories and centres. \\
\hline Pâstâhowin & $\begin{array}{l}\text { The consequences of breaking of political agreements or the } \\
\text { breaking of laws against another human being. Also } \\
\text { connection to sacred law. }\end{array}$ \\
\hline Pakitinasiwin & Leaving something behind as an offering. \\
\hline Simâkanis & $\begin{array}{l}\text { Warriors/peacekeepers. Ancient concept due to reference of } \\
\text { spear point. }\end{array}$ \\
\hline Socheweyin & Consequences of breaking the law. \\
\hline Tagakechemun & Asking people, consulting people. \\
\hline Tawinamakewin & $\begin{array}{l}\text { A person is welcome. Consider well-being of community. } \\
\text { Make room. Implies control. }\end{array}$ \\
\hline Tipethimisowin/Tipínimisiwin & $\begin{array}{l}\text { The exercise of sovereignty. Self-government. Own authority } \\
\text { used at self and nation level. Freedom. }\end{array}$ \\
\hline Wahkohtowin & Refers to the laws governing all relations. \\
\hline Wansaytanow & $\begin{array}{l}\text { In Cree for "lawyer". Someone that is trying to make things } \\
\text { right. }\end{array}$ \\
\hline Wekokumowin & Asking people to come out to a debate. \\
\hline Weetumatowin & Sharing information. \\
\hline Wîcihitowin & The act of helping each other. \\
\hline
\end{tabular}


Additional Cree concepts found in the literature but not discussed in this dissertation can be found in Appendix F.

\subsection{Discussion}

Since I am Nehinuw and I have long been interest in governance, I wanted to know what is Nehinuw governance. I designed the central research question of this study to answer that question by asking what does Nehinuw knowledge teach us about Nehinuw governance. In addition to this research question, I also wanted to design this dissertation according to the Nehinuw research paradigm. With my topic and theoretical framework in hand, I proceeded to conduct this dissertation. Once I was in the field, I quickly realized that I would have to rely on the emerging structure of my dissertation. I made this realization shortly before I started to interview the first participant. I looked at my list of governance focused questions and knew that I could not simply ask the list of questions. This type of interview would not have been consistent with the Nehinuw research paradigm. I needed to develop a relationship with my participants. Thus, instead of beginning my interviews with the first question, what is Nehinuw governance, I asked some broader questions about the Nehinuw, such as: who are we? and how do you say that in the Nehinuw language? I did not think that these general questions would lead to anything connected to the central question of this dissertation, but I realized that to truly answer my research question I would need to answer who are the Nehinuw and how do the Nehinuw research? These two questions helped me gain a deeper understanding of Nehinuw governance. But now that I have completed this dissertation, how can this knowledge be used to support the future of Nehinuw governance? In this section I want to discuss what I have learned in this dissertation centred around four lingering questions, who are the Nehinuw, what is Nehinuw research, what is Nehinuw governance, and what is the future of Nehinuw governance? 
First, understanding Nehinuw identity is critical to understanding the central research question of this dissertation because identity is intricately tied to the theories and practices of Nehinuw governance. I framed this dissertation around the Nehinuw, but this approach may not go far enough to represent Nehinuw understandings of identity. Nehinuw is a Cree concept that is used to describe a specific group of Cree people. In language texts, Nehinuw references a specific dialect of Cree, the $\mathrm{N}$ dialect, which is spoken between in my community, Cumberland House, and the shores of James Bay in Northern Ontario. However, as I started to talk with my participants, I realized that there are multiple ways to frame Nehinuw identity. Brightman's (1993) description of Cree identity as highly relational and dynamic is accurate. In the Nehinuw language, the Nehinuw use multiple concepts to discuss identity, each of these concepts is highly descriptive, and these concepts are applied in various situations. To complicate matters further, multiple non-Nehinuw terms are being used, such as Cree, First Nations, Swampy Cree, or Indigenous, and colonization has introduced new identity frameworks, such as Aboriginal, status, and treaty. In future research, I would like to explore how these identity frameworks have shifted Nehinuw identity. Palmater's work (2000, 2011a, 2013) on Indian status shows that status has changed Indigenous theories of citizenship and created an identity framework of exclusion and termination, who is and is not Indian based on blood quantum. This identity question is relvant to the study of Nehinuw governance because shifting identity impacts the theories and practices of Nehinuw governance.

There are numerous ways I would like to explore the interconnection between shifting identity and governance. For example, how has treaty impacted Nehinuw identity? Most of the traditional territory of the Nehinuw people is located within the boundaries of Treaty 5. Treaty theory and practices are central to Nehinuw governance. Treaty 5 is central to establishment of 
Nehinuw/Settler relations. However, in the current social and political context, the Nehinuw identify with Treaty 5. Since it has been 143 years since Treaty 5, how does identifying with treaty shift Nehinuw conceptions of space and identity? For example, the reserve system created by Treaty 5 has changed Nehinuw understandings of land and identity. We identify a specific reserve or community as a place of origin instead of Nehinuw territory. The land usage of the Nehinuw extends beyond Treaty 5 (Meyers, Gibson, \& Russell, 1992).

Furthermore, how have provincial boundaries impacted Indigenous identity? For example, the Nehinuw territory is divided by the Saskatchewan/Manitoba border. Cumberland House and Opaskwayak are two Nehinuw communities both signatories to Treaty 5, yet they also participate in seperate social and political forums that do not cross provincial boundaries. Cumberland House Cree Nation participates in the Prince Albert Grand Council, which represents the First Nations in North-Eastern Saskatchewan, and Opaskwayak presently independent has participated in Swampy Cree Tribal Council, which represents First Nations in North-Central Manitoba. What are the implications of this provincial division of the Nehinuw people? The settler-colonial identity frameworks have created artificial borders between our people, created tensions within Indigenous communities, diminished Indigenous governance theories and practices, and shifted Indigenous worldviews. We, as Nehinuw and Indigenous people, need to evaluate the impact colonization has had on our language and the impacts these changes have had on our society. Some of these changes may seem minor, but changes in language have a significant impact on our values and philosophies (Fanon, 1963). NonIndigenous people need to understand the impacts of the colonial identity frameworks otherwise they will continue to reinforce the colonial frameworks. This deeper understanding of Nehinuw identity helped me to critically reflect on Indigenous methodology. Since we are only beginning 
to understand the depths of Indigenous identity, we are also only beginning to understand the diversity of Indigenous knowledge and methodologies. I believe that if we truly desire to learn about Indigenous people and knowledge, there must be an effort to research from specific Indigenous research paradigms, which is why I attempted to research from a Nehinuw research paradigm.

The Nehinuw research paradigm is a theoretical framework based around the Nehinuw worldview. I developed the framework used in this dissertation based on my experiences as a Nehinuw man, Nehinuw scholarship, and Indigenous literature. I want to continue to refine this paradigm in collaboration with the Nehinuw people. This paradigm has allowed me to develop a deep understanding of Nehinuw governance from a Nehinuw perspective. Now that I have completed this dissertation, I wonder if this dissertation has been completed from a Nehinuw research paradigm or have I simply incorporated elements of non-Indigenous and Indigenous practices that suit my desired approach? I think this dissertation is a Nehinuw dissertation because of my use of Nehinuw research protocols, the commitment to meaningful community engagement, and the creation of a unique method of analysis. My method of analysis, based on the Nistotên concept, allowed me to complete this dissertation utilizing a Nehinuw framework of understanding. However, I feel that I am only just beginning to understand this paradigm. My goal is to become fluent in the Nehinuw language. I want to conduct research entirely in the language using the principles mentioned above and used in this dissertation. At that point perhaps, we can say we have decolonized our methodology and truly understand what we are researching.

The point I want to make on methodology is for future researchers, especially Nehinuw and Indigenous researchers. When I started this dissertation, I had not thought critically about 
what it meant to conduct a research project on the scale of a dissertation. I did know that I wanted to design this dissertation using a Nehinuw research paradigm, but I did not know what that entailed. As I learned more about the Nehinuw research paradigm, I realized that my envisioned approach would have to change. I moved away from my social science and public policy training and education towards the Nehinuw paradigm. This means approaching my proposed topic with an open mind and heart. For example, I began with a very academic list of interview questions, but I did not want an academic assessment of Nehinuw governance. I wanted to learn about Nehinuw governance in Nehinuw terms. The best way to learn about Indigenous knowledge is from an Indigenous paradigm. Indigenous knowledge is legitimate, and I urge others to research from an Indigenous paradigm if the goal and desire is to understand Indigenous knowledge and governance.

Using this research paradigm, this dissertation helped me gained a deeper understanding of Nehinuw and Indigenous governance. I learned from Nehinuw Elders and experts that Nehinuw governance is a dynamic and complex interaction between individuals, communities, and various legal systems. One philosophy that stands out is Kiwicitowek Insiniwuk (working together). Kiwicitowek Insiniwuk is a decision-making theory and practice, which emphasizes communal understanding and participation. This theory and practice stands out because of the emphasis on working together. The past was not perfect. There was conflict and individualism, but what was important was how we worked together. We worked together as individuals and communities to implement Nehinuw governance. The power of Nehinuw governance is meaningless without a source of legitimacy. Nehinuw governance was legitimate because everyone understood and practiced Nehinuw ethical and moral teachings. In other words, the 
resurgence of Nehinuw governance requires a resurgence of Nehinuw spirituality (Wastesicoot, 2015).

The problem is that resurgence is a long-term and theoretical process. The challenge for the future of Nehinuw governance to find a balance between resurgence and resisting the policies of ongoing colonization. Contemporary Nehinuw leaders must navigate termination, assimilation, poverty, unemployment, and violence while also being asked to pursue the resurgence of Nehinuw governance. Thus, asking leadership and nations to undertake a theoretical process rather than devoting its limited resources to addressing these major socioeconomic problems is naïve and presumptuous. My answer is that we can work together because I think that is how we have survived and gotten to this point with a living, albeit threatened, body of knowledge. I recall the five resurgence strategies that I identified in chapter 2, resistance, control, internationalization, ideational, and indigenization. There has never been one central strategy or actor in the survival of Indigenous people and knowledge. The unknown mother raising her children is just as important as the front-line activist. Consider Idle No More, four women were central to the start of the specific Idle No More movement, but that movement had existed in the hearts of all Indigenous people.

My hope is that I can help by learning and recording the knowledge of Nehinuw governance. Resurgence is an incremental and long-term process. This dissertation is a first step that I want to take towards the resurgence of Nehinuw governance. I do not expect that someone who has been impacted by colonization to instantly embrace resurgence. As we include these Nehinuw governance concepts within our community education system, the next generation will become aware of Nehinuw governance theories and practices. Intergenerational dialogue is integral to the success of this resurgence. For example, what is Kiwicitowek Insiniwuk (working 
together) and how can this principle be incorporated by the community into Nehinuw governance structures? Kiwicîtowek Insiniwuk required people to reach consensus, and often the leaders would talk to everyone in the community. I think our people can adapt and incorporate these values and philosophies with some flexibility. However, if we do not talk about these values, and we do not teach our youth these values and philosophies, we will continue to recreate and use the Euro-Canadian Indigenous governance framework that has been imposed for over 150 years. So far there was an overwhelmingly positive response from the communities, and I intend to pursue future funding to continue the research started in this dissertation. Learning about these governance structures will continue to help the community continue the path to resurgence.

In many ways, the internal resurgence of Nehinuw governance that I am proposing in this dissertation has begun. However, resurgency will only be successful if we use multiple resurgence strategies. Focusing only on indigenization of Nehinuw governance ignores the reality of contemporary global public problems. For example, the communities I have visited in this dissertation, Cumberland House and Opaskwayak Cree Nation, are facing a water crisis. In addition to the 2016 upstream oil spill, the quality and quantity of water has continually diminished. The factors causing this water crisis do not originate in Nehinuw territory. To address this global problem, we must continue to establish relationships with other nations and be open to alternative methodologies. The important point going forward is that we begin to identify the core governance theories and practices that are essential to Nehinuw society. For example, Nehinuw treaty theory has been the basis for the Nehinuw settler relationship. If we continue to focus only on the past and not address how we change and adapt, we risk isolating ourselves internally and internationally. Thus, I hope this dissertation can be a starting point of 
discussion on change. What are our core theories and practices? What can and should change? Our communities are impoverished. Does that mean we blindly accept the next economic development project? No, we have specific legal systems, Ohcinêwin, that tells us to respect the land. If we are guided by the knowledge of the past, I believe we use this knowledge of Nehinuw governance to address future.

We also need to continue to challenge the ongoing colonization under the Canadian Indigenous governance framework. Some scholars suggest that reforming the framework would be the best normative direction forward to achieve improved quality of life for Indigenous people (Alcantara, 2007; Cairns, 2000; Flanagan, 2000; Flanagan, Alcantara, \& Dressay, 2010; Gibson, 2009; Provart, 2003; Russell, 2017). Sanderson (2014) argues that laws like the Indian Act are necessary to maintain Canadian Indigenous relations because they provide certainty. Many Indigenous voices would rather see the Canadian Indigenous governance framework replaced with a nation-to-nation structure that empowers Indigenous political theory and practices (Alfred, 2009a; Corntassel, 2012b; Henderson, 1994; Little Bear, Boldt, \& Long, 1984; Manuel \& Posluns, 1974; McAdam, 2015; Mercredi \& Turpel, 1993; Palmater, 2013). For this shift to occur, Canada would have to reject its claims to sovereignty founded on the doctrine of discovery and terra nullius. However, the practical implications of erasing the Canadian Indigenous governance framework are real. Abolishing responsibilities would leave Indigenous nations without any legal protection, significant source of revenue, or land. Indigenous nations would have to rely on their land base to support a nation-to-nation relationship and only " $0.2 \%$ of the total land area of Canada" is Indigenous lands (Indigenous and Northern Affairs Canada, 2010, para. 3). Thus, Sanderson's (2014) point on the protection of the Canadian Indigenous governance framework is valid. I do not have a creative solution for the transition period 
between colonization and decolonization. However, I do believe that Indigenous nations need to continue to reassert our Indigenous governance theories and practices. We need to implement Dene, Nehinuw, Nêhiyaw, and every Indigenous nation's governance theories and practices. We also need to study and record Indigenous governance theories and practices. If we do not attempt to build the future of Indigenous governance around Indigenous knowledge, what is the point of all this resurgence. Furthermore, without exploring the diversity of Indigenous governances, there is a danger that we homogenize the theories and practices of Indigenous governance, which achieves the same result as assimilation. I hope this dissertation, which explores Nehinuw governance theories and practices, contributes to the resurgence and inspires you to act.

Finally, for the non-Indigenous people, if you are truly interested in decolonization you need to Nistotên (to understand). Nistotên is a method of analysis based on the Nehinuw world view that includes experience, sharing, and understanding. I feel that the stages of Nistotên lead to a more meaningful level of understanding. My Nehinuw participants stressed that understanding was critical to decolonize the relationship between Indigenous and nonIndigenous people. Even in a situation where the Indigenous community visibly displays their values on the wall, there is still not enough of an effort made by non-Indigenous stakeholders to understand the Indigenous worldview. The question then is, how do you understand? Nistotên is a framework of understanding built around experience and sharing. You must learn the values of our nations and then experience and share these values. You need to go into the community, to go on the land, to take part in our ceremonies, to learn our language and to ask the community what they can do to understand their way of life. Because the reason for the lack of action and ongoing colonization is not just the state. The reason the recommendations of the Royal 
Commission on Aboriginal People and UNDRIP have not been implemented is because there has never been the political will to change. Canadian society has yet to truly understand that decolonization means loss for non-Indigenous people. There is no monetary value to decolonization. We are talking about equal partnership or returning of the land. Action requires a long, self-reflective look into the mirror.

\subsection{Future Research}

As I mentioned above, this dissertation has been a life-changing event and process because I learned about my people and myself. I learned more about the dynamic nature of the Nehinuw worldview, which includes perspectives on identity, research, ceremony, and governance. Now that I am at the end of this dissertation, I find myself wanting to know more about my people. I have many questions that I would like to address in future research. I would like to pursue these ideas with future research to learn more about my people and preserve this knowledge for the future generations of my community. I am specifically interested to learn more about the interconnection between identity and Nehinuw governance theories and practices.

Indigenous governance is a growing field in academia (Belanger \& Newhouse, 2004; von der Porten, 2012), and it is increasingly used by Indigenous people. For Ladner (2001b), there is considerable benefit to the exploration of Indigenous governance in Indigenous terms. I feel her argument accurately captures what I see as the decolonization of Indigenous governance, the framing of Indigenous governance in Indigenous terms. The problem is that a large portion of the literature attempts to make pan-Indigenous comparisons (von der Porten, 2012). However, throughout my dissertation I have come to believe that more research is needed based on the diversity of Indigenous worldviews (Altamirano-Jiménez, 2008; Simpson, 2008c). For example, I grew up Cree and still many people use this term to talk about our people, but it is not a Cree 
term. Nehinuw identity is extremely relational (Brightman, 1993). Even for my people, the Nehinuw, we use a diverse set of terms to reference their identity including but not limited to Nehinuw", “Ininew”, and "Waskahikanihk” (Goulet, 2013; Goulet \& Goulet, 2014). As one participant noted, "there has never been an effort to sit down and make a consensus on the term used." This fluid view of identity fits with Battiste and Henderson (2000) and Deloria Jr.'s (1972, 1997) view of Indigenous knowledge. There are a lot of commonalities, especially when we compare how Indigenous people have been colonized. But when you really get to talk and compare different groups of Cree, Nehinuw, Nêhiyaw, Nehetho, Inininew and so on you will see that there are considerable differences between our people. I feel this diversity should be celebrated, practiced, and be the basis for revitalization. Thus, in a future research project I would like to explore governance theories and practices of other Indigenous nations. I would begin by working with the Cree nations before working with other nations. Ideally, this project would attract individuals from these nations and these individuals would be the voices for their nations.

Furthermore, I have also developed a deeper understanding of Nehinuw governance during this dissertation. Going into this dissertation, I thought there would be a much simpler answer to my research question, but I realized that Nehinuw governance is much more dynamic and complex. I would like to continue to explore the theories and practices of Nehinuw governance. I have four key Nehinuw governance questions that I would like to explore in future research. First, what are the specific protocols of each theory and explored in this dissertation? For example, what are the specific protocols of Wahkohtowin? Second, what are the other Nehinuw governance theories and practices that I did not cover in this dissertation? For example, Cardinal and Hildebrandt (2000) discuss Miyo-wichetowin as a key principle of Cree 
governance. Do the Nehinuw also follow this principle? Third, how do other Nehinuw communities view these theories and practices discussed in this dissertation? For example, my participants discussed several Okimâwiwayin (leadership law). Do other Nehinuw communities have the same rules and understanding of Okimâwiwayin? Finally, how are these theories and practices incorporated in contemporary organizations? For example, Kiwicîtowek Insiniwuk (working together) is a key Nehinuw governance philosophy. How have contemporary organizations such as tribal councils incorporated this philosophy?

I would answer these questions using the research paradigm implemented in this dissertation. However, I would like to continue to work with Nehinuw communities and Elders to explore this paradigm. I used the concept of Weehihitowin as the research methodology of this dissertation. What other prespectives are there on Nehinuw methodology? I used Weetumatowin as the primary method to gather knowledge. How are the other narrative forms of the Nehinuw language used in the Nehinuw intellectual tradition? Nistotên is one framework of analysis. Are there other methods of Nehinuw analysis? How does this method compare with other Indigenous nations? I want these future research questions to benefit Nehinuw communities.

Ideally, I would like to work with local educators to develop Nehinuw curriculum that could be used for educational and governance purposes. Another idea would be to establish a Nehinuw Language Council that identifies new words and advances the use and understanding of existing words. Since the communities I worked with in this dissertation are passionate about knowledge revival, for example Opaskwayak Cree Nation has recently developed a dictionary and mobile phone language application, I think there is great potential for this project. Developing new words is critical, because Nehinuw society does not exist in isolation. How do 
we say kiwi, cell phone, constitution, or any other words that have only been recently part of the Nehinuw experience? I know there have been attempts to create new words by individuals. For example, McLeod (2016) created many new Cree words in his work 100 Days of Cree. I think it is important to work towards a community level consensus if new words are to be created, which is why I am proposing that these new words be created by a language council like the Anishinaabe language council (Minnesota Humanities Center, 2009).

\subsection{Lessons}

Before I close this dissertation, I would like to share with you some important lessons that I learned from my participants and my knowledge journey. These lessons are valuable suggestions on how to improve our communities, and how non-Indigenous communities could better work with Indigenous communities. The non-Indigenous community needs to come into Indigenous communities with an open mind. There was a shared sentiment amongst my participants that despite all the dialogue on decolonization and reconciliation that nonIndigenous people still struggle to understand Nehinuw communities.

Respondent 1: I think to listen - not to come there with your own agenda, to have an open mind on what this group too many times a group coming in and saying 'this is what we want to do' [or]'this is how it's going to be done'.

The struggle to understand comes from a lack of commitment to create meaningful relationships. Meaningful relationships can only be achieved through commitment.

Respondent 2: Meaningful consultation is coming into our community, meeting with our leadership, sharing their proposed plan, and identifying the benefits to our community. For example, they could be hiring our people and employment of our 
people. That's always the main issue that they can hire. So that settled and bringing it to the people. Any organization that wants to come and partner in any agreement it comes back to our community. The people are called and they're provided that information. A lot of times, our people will make additional recommendations. So it's involvement, involving the people.

Furthermore, meaningful relationships require that the non-Indigenous individuals and institutions will do a better job of utilizing and accepting Indigenous knowledge.

Respondent 3: I would hope that they would accept that people in communities can actually have an input in a very significant manner. That they have a good working knowledge of what they need in their community. They want to be able to have some authority in the decision-making process so that they have a long-term impact on the community in mind.

The utilization and acceptance of Indigenous knowledge should be extended to worldview. Indigenous people have different worldviews.

Respondent 5: I think that we have a different way of thinking about that we are all related and that we consider - we have ideas like 'Ohcinêwin' and 'Pâstâhowin'.

Ceremonial is not symbolic. Ceremony binds decisions with the land, people and the Creator. Ceremony is the highest form of Nehinuw law.

Respondent 6: Most non-Aboriginal people, they don't want to hear about that. They make fun of it. I've heard some bureaucrats say, well, that's a symbolic thing. 
You know, and these are the people that are supposed to be working for us, from Indian Affairs.

They say it's a symbolic thing. It's not a symbolic thing. It's done based on my witnesses. When I say "my witnesses" people don't understand what I'm talking about. See, they're based on the sun, moon, stars, the earth, the water, the air and the fire. That was what it was based on, because that's the environment we lived in.

Developing meaningful understanding requires a learning of history. Local and national history Indigenous nations have common and unique experiences.

Respondent 7: I would say learn a little bit about our history, where we came from. How disruptive residential school was? How our relationship is with the government. Why we're here and why are the treaties important to us? Like even though they're outdated and old why do these people just cling to them as our only source of living. So, they need to learn a little bit about us and learn about what it's important to us now, in this day and age. And you build that, you build that relationship.

Understanding should be extended to Indigenous lands. Non-Indigenous people need to make the effort to go out on Indigenous lands and experience our communities and worldview. Respondent 9: First, you need to have dialogue. I think eventually even if it takes time to talk they will understand each other. Then you have to go for trips to their 
respectful camps. So you show them how you made your living. So they understand how you have to get to your land.

I began this dissertation trying to fit Indigenous knowledge into western research and it was a struggle. However, as I progressed further into my dissertation and learned about Indigenous research, I stopped struggling with the apparent clash between these two worldviews. I stopped trying to justify Indigenous methodologies. I stopped trying to fit Indigenous research and methodology into the western framework. I found inspiration in the work of my supervisor Dr. Lynn Lavallée, who bridges the gap between Indigenous and western research. I think she was successful because she knew in her heart that Indigenous knowledge is valid. I do not know if the concerns of the western world will ever be satisfied with Indigenous knowledge. These western frameworks raise some interesting questions. For example, can a written document accommodate for the oral traditions of the Nehinuw people? Furthermore, how do we reconcile the lifelong education process with the fixed timeframe of a Ph.D.? I do not know if I can answer these questions. However, I do know that Indigenous knowledge is valid. It is valid because we are here. In addition to being valid, our knowledge is complex. Being on the land, being people that observe and reflect, the Nehinuw have always conducted research. I designed this dissertation in a way that would honour the research theories and practices of my people. I encourage others to cast aside any doubts they have and if they are ever challenged cite our existence.

All the efforts I have taken to research from an Indigenous paradigm were implemented because I am working with Indigenous knowledge in this dissertation. However, despite all the efforts I have taked, the question remains is there a source of "pure" Indigenous knowledge? I 
do not have the answer to that question. Colonization and western influence has been extremely pervasive. However, I believe that Indigenous knowledge is alive, and it is contained in the language. The work of resurgence is to interpret the language in a way that fits contemporary society and these interpretations should be shared with the community. For example, Ohcinêwin is the law of the land. What does this concept mean now in the context of natural resource development? As I worked with the participants in this dissertation, people who are Elders and experts in their communities, I could see the interpretive resurgence in action. The interpretation happened during the Weetumatowin (sharing knowledge) of this dissertation, which is why I want to continue this work. I want to support the resurgence.

Finally, gender raises some challenging and important issues for Indigenous knowledge and methodology. I assumed that my focus on Indigenous knowledge and the community empowerment potential of the snowball selection method did not require gender analysis. I thought that this was appropriate considering the threatened status of Indigenous knowledge and the use of specific Elders as theoretical frameworks in various Indigenous intellectual traditions (Steinhauer-Hill, 2008; Stiegelbauer, 1996). The issue is that Indigenous knowledge is often portrayed as gender-neutral even though men are disproportionately used as knowledge sources (Snyder, 2016). I did not consider this factor until I had completed the research for this dissertation, and at that point I realized that I inadequately critiqued my topic and methodology using gender as a lens. Thus, this dissertation does not show a gender-neutral interpretation of Nehinuw governance. My goal for future research is to intentionally focus on alternative gender understandings of Nehinuw governance. However, the desire for gender-neutrality creates some challenging issues for Indigenous knowledge and methodology. What is the balance between the protection of knowledge and gender-neutrality? In other words, is there value in research that 
does not fundamentally assess the topic and methodology using gender? Furthermore, considering the damage caused by colonization, can we ever explore a gender-neutral or patriarchal alternative view of Indigenous knowledge? I believe as long as the language is alive then the knowledge is alive. Thus, this dissertation has made an original contribution to the study of Nehinuw governance by exploring Nehinuw governance in Nehinuw terms, albeit a predominately male interpretation. However, if we are truly interested in developing a genderneutral view, more research is needed that restructures our understanding of the topic of governance and intentionally avoids the use of men as knowledge sources.

\subsection{Closing}

For several reasons, I have never been spiritual. Stonechild (2016) elaborates on many of the reasons that Indigenous people are challenged by religion and spirituality, such as the legacy of residential schools. Unlike some of the people that Stonechild profiles in his book, the source of my Indigeneity has been my territory and culture. I was raised on the land and immersed in Nehinuw culture. My confidence in my Indigeneity has never faltered because I knew who I was, and I have been able to continuously return to my traditional territory. I never cared if people said I looked white, or that I was not part of the community because I was not status or treaty. I know that I am Nehinuw. I am proud to represent the Nehinuw people. This dissertation has helped me find my sense of origin.

The first class in my Ph.D. program was Research Foundations of Social Science. This course explored various perspectives on the philosophical roots of social science research. I have never liked philosophy, but this class was a revelation. For the first time in my life I understood the purpose of philosophy. One key moment in that class revolved around the purposes of academia. According to Professor Mehrunnisa Ali, as a Ph.D. candidate, you shift 
from knowledge consumer to knowledge producer. This observation had a profound impact on me because it forced me to deeply reflect on my role in academia. I did not see myself as a knowledge producer, rather I wanted my research to represent the knowledge of my people. So, the question that drove the design of my dissertation was, how do I conduct research in a way that represents my people, the Nehinuw?

At first, I struggled to develop a Nehinuw dissertation because I was trying to use nonIndigenous theories and literature as the theoretical foundation of my dissertation. Through a lot of reflection and discussions with my supervisor, I realized that what I wanted to do was much simpler than the dissertation I was trying to design. I knew who my people were and I knew about our cultural practices, so I decided to design this dissertation according to the Nehinuw worldview and I feel I have achieved this goal. I feel this dissertation is an example of how our people conduct research. We experience our knowledge. We pass on our knowledge through oral traditions. We develop lifelong relationships. We share knowledge with future generations.

Despite all the efforts I have taken to honour my ancestors and the way the Nehinuw conduct research, one of my weaknesses was my connection to the spiritual component of our people. I have heard many Elders discuss the importance of our spirituality. I have practiced many aspects of Nehinuw spirituality throughout my life. Stonechild (2016) discusses many ways Indigenous people can be spiritual. For Shawn Wilson (2008), spirituality is important for research because research is ceremony. Going on the land has been one of the ceremonies I have been able to incorporate into this dissertation. The land has helped me understand Nehinuw analysis, but ceremony is more than going out on the land. One of my participants helped me gain a deeper understanding of the important of ceremony. Ceremony binds you to the land, people, and the Creator. Ceremony represents a commitment to something more than yourself. 
It represents a commitment to the past, present, and future. But how have I incorporated ceremony into my research?

I have incorporated several elements of ceremony in this dissertation, going on the land, medicine as consent, and developing relationships with my participants. But I want to do more in my life and research to incorporate spirituality and ceremony. I have already made a commitment in this dissertation to learn more about the ceremonies and protocols of Nehinuw governance. The one final thing that I would like to do with this dissertation, as a closing ceremony, is to make an offering. Making an offering is an important part of my people's ceremony. We usually make an offering on the land by leaving sacred medicines or gifts. One time I was on the land and we left some food. One time I was on the land and instead of making a kill, we put away our weapons and said we will leave some for the future. The issue I have been struggling as I finish this dissertation is incorporating this offering ceremony into this dissertation. The offering I make now in closing is an offering to the youth of my community. I believe in you, and I want to help you achieve great things. I am always free to talk with you, but I also want to offer you this dissertation. This dissertation is not my dissertation. This dissertation contains the knowledge of our people. I hope you learn these words and practice the governance of our people because this knowledge has helped us survive since time immemorial, and I believe that it will help us survive until time immemorial.

Ekosi Kinanâskomitinâwâw (That's all for now I am grateful to you all) 


\section{Appendices}

\section{Appendix A: Saskatchewan River Delta Map}

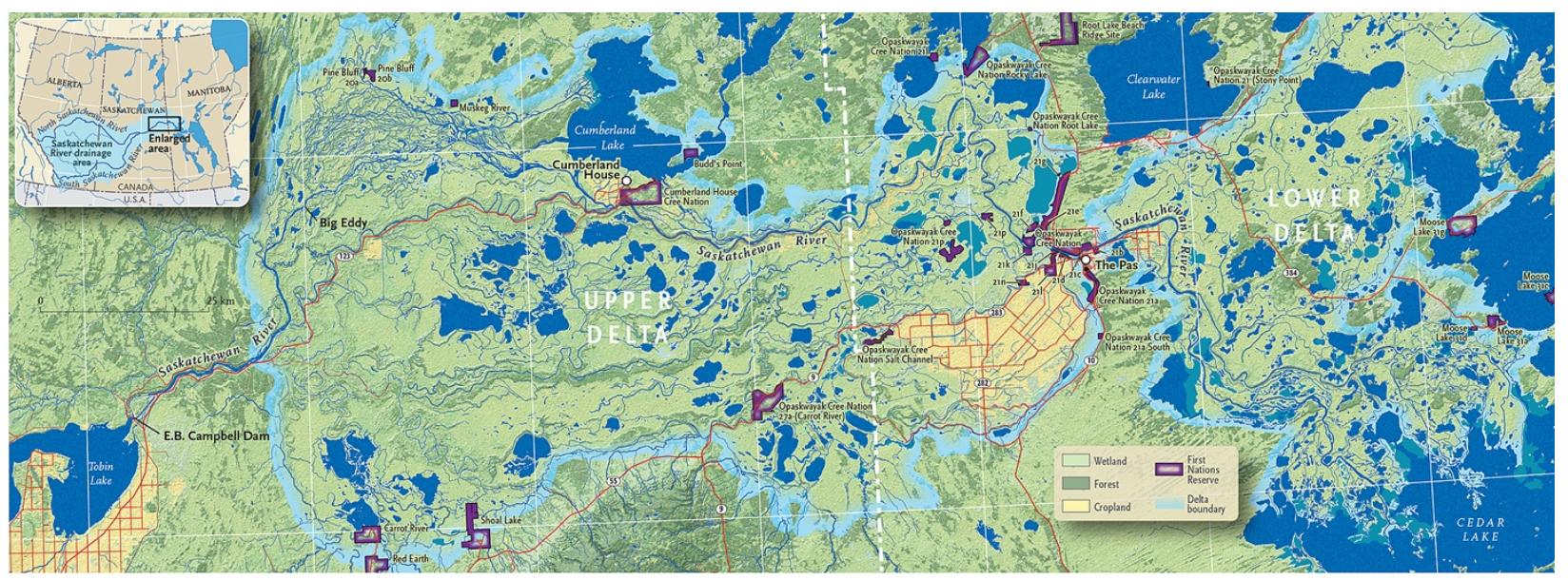




\section{Appendix B: Research Agreements}

P.O. Box 220

Cumberland House, SK SOE OSO

Website: http://www.chen.ca

Email: chcn@sasktel.net

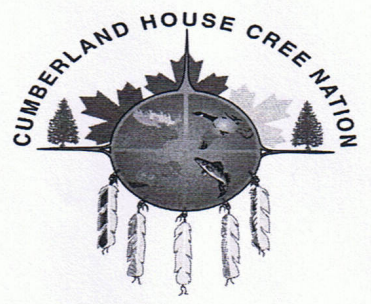

Phone: (306) 888-4778

(306) $888-2152$

(306) $888-2116$

(306) $888-2011$

Fax: $\quad$ (306) 888-4488

Fax: $\quad$ (306) 888-2084

June 23, 2014

Mr. Riel Carriere

Box 304

Cumberland House, SK

SOE OSO

RE: Research Project in Cumberland House Cree Nation

Dear Mr. Carriere

Chief and Council have reviewed your letter to conduct a research project in our community. We support your project in principle to conduct research and contact people for interviews in our community.

We ask that Cumberland House Cree Nation obtain the rights to the finalized project for our future generations.

Please contact myself at the Band Office 306.888 .2226 or on my cell 306.981.2890 for future reference.

Yours in Indian Government,

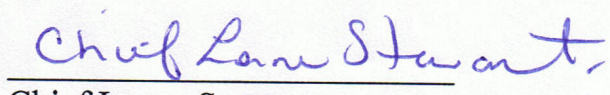

Chief Lorne Stewart

Cumberland House Cree Nation \#350 


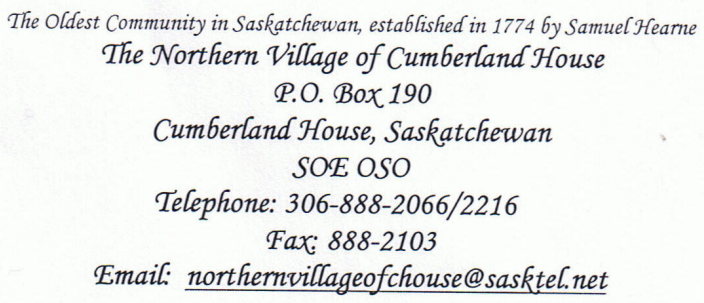

June 23, 2014

\author{
Real Carriere \\ Box 304 \\ Cumberland House, Sask \\ SOE 0S0 \\ (H) 306-888-2104 \\ (C) 306-888-4305 \\ Real.carriere@ryerson.ca
}

Re: Letter of Support for Real Carriere Research Project

Cumberland House is a unique community and is also the oldest settlement in Saskatchewan and boasts one of the largest delta's in the world. A traditional Métis and First Nation Community, Rich in history.

On behalf of the Northern Village of Cumberland House, we would like to support the research project and the sharing project circle that will be conducted in our village.

Sincerely,

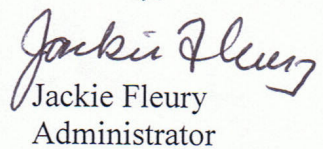

Cc Mayor \& council 


\section{OPASKUZIAYAK CREE DACION}

\begin{tabular}{lll}
\hline P.O. BOX 10880 & \multicolumn{1}{c}{ OPASKWAYAK, MANITOBA R0B 2J0 } & \multicolumn{1}{l}{ 1-888-763-1566 } \\
\hline TELEPHONE: (204)627-7100 & ADMIN FAX NO.: (204)623-5263 & CHIEF'S OFFICE FAX NO.: (204)623-3819
\end{tabular}

May 27,2014

Mr. Real Carriere

Box 304

CUMBERLAND HOUSE, SK

SOE OEO

Dear Mr. Carriere;

RE: Opaskwayak Cree Nation - Research Project

At the Chief and Council meeting of May 20, 2014, Chief and Council reviewed your letter of request to conduct a research project in our community. We support your project, in principle, to conduct a sharing circle in the community.

We ask that Opaskwayak Cree Nation obtain the rights to the finalized paper/information for our future generations.

Please contact the undersigned at the above address/number or at joan.niquanicappo@opaskwayak.ca.

Yours truly,

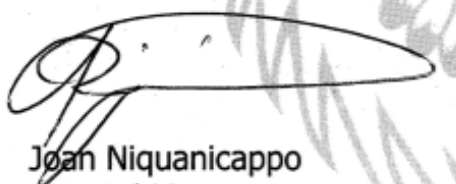

General Manager

xc Chief Constant

File 


\section{Appendix C: Consent Form}

Interview: Letter of Information

Dear Participant,

You are being asked to participate in a research study that is part of my Ph.D research.

Before you consent to participate, please read the following information. Ask as many questions as you need to be sure you know what you will be asked to do.

Investigators:

Real Carriere, Ph.D. Candidate, Policy Studies, Ryerson University

Supervisor:

Lynn Lavallée, Ph.D., Associate Professor, Social Work, Ryerson University

Purpose of the Study:

The purpose of this study is to explore how the Nehinuw (Cree) people understand policy. Nehinuw people with their unique worldview have a specific language and process for developing policy in their territory. This study wants to explore what policy means to you as a Nehinuw.

Eligibility:

To participate you must self-identify as Nehinuw (Cree). First Nations (status or nonstatus), Métis (registered or non-registered), or Inuit of all ages are welcomed to participate. In addition, you will have experience in governance in your community.

Description of the Study:

As a Nehinuw (Cree) we want to get your thoughts on policy. This includes a much broader discussion on how policy, law, and governance translates into the Nehinuw language and world view. What does traditional Nehinuw policy-making involve? How does the current process differ from this traditional approach? You will be asked to take part in an interview to gather information about the Nehinuw policy process. Each interview will last no more than 2 hours.

\section{Digital Audio-Recording:}

We would like to audio-record the sessions. If you do not agree to the audio-recording then the discussion will not be recorded, instead, I will take detailed notes. All audio recordings will be typed out word for word but your name will not be included in the notes. Any other information that might personally identify you will be modified to protect your identity.

Benefits:

1. All communities involved in this project will received a final draft of this project and be involved throughout the development of this project. Discussing traditional knowledge on 
governance will be beneficial to the communities as this project will support the transmission of knowledge between generations of Nehinuw.

2. Understanding how Nehinuw (Cree) have made policy in Nehinuw territory will help all stakeholders that want to work with the Nehinuw in the future. Having a solid understanding of the policy process is vital for all stakeholders to be able to have impacts at a broader level than the individual or to understand why they might not be having the influence they expect or want.

Risks or Discomforts:

The risks to you are minimal. One of the risks of this research is the perception that this research is going to be critical of leadership in your community. That is not the intent of this research. However, if you feel uncomfortable with any questions you do not need to answer them.

\section{Incentive:}

You will be given $\$ 20$ for taking part in the interview. If you stop participating or have to leave early you will still be given the $\$ 20$. The payment will be given at the end of the interview or if you leave early the payment will be given to you at that time. In addition to this $\$ 20$ honourarium you will be offered a small bundle of traditional medicines.

Costs:

There are no expected costs associated with your participation in this study.

Confidentiality:

It is important to us to protect your privacy. Here is how we will do so:

- Your identity (first name and last name) will not be shared. Instead, you will be given a pseudonym. This pseudonym will be used in all written materials.

- All paper data will be locked in a filing cabinet in my supervisor's office at Ryerson University. Only myself and my supervisor will have access to the data. Electronic data will be stored on a password protected and/or encrypted laptop and/or USB key.

- Audiofiles will be destroyed upon completion of the transcripts. The raw data (transcripts) will be destroyed after 2 years, until the completion of my doctoral studies. Confidential data will be destroyed upon the successful defence of this project. Public data will be shared with communities as they wish.

Voluntary Nature of Participation:

Participation in this study is voluntary. Your choice of whether or not to participate will not influence your future relations with the project lead Real Carriere, your community, my supervisor or Ryeson University.

If you decide to participate, you may refuse to answer any particular question or stop participating all together at any time. You will still be given the $\$ 20$ honorarium if you stop participating.

Questions about the Study: 
If you have any questions about the research now, please ask. Please keep this letter of information. If you have questions, concerns or complaints about the research later, first try to contact myself at:

Real Carriere

Box 304, Cumberland House, SK S0E 0S0

C: $647-460-4305$

H: $306-888-2104$

Email: real.carriere@ryerson.ca

You can also contact my supervisor.

Lynn Lavallee

350 Victoria Street, Toronto, M5B 2K3

W: $4169795000 \times 4791$

Email: lavallee@,ryerson.ca

Or contact your community administration and they can forward your questions on to me or my supervisor. 


\section{Appendix D: Weetumatowin Guide}

Exchange of traditional medicines and thanks for support.

Introduction to Project

Potential probes:

1. Any thoughts, questions or comments on my project?

2. Do you understand what I'm trying to capture with this project?

3. How do you think I should go about trying to gather this information?

\section{Nehinuw Methodology Questions:}

4. In your community, how do you go about to gather knowledge or teachings?

a. Maybe the word "knowledge" is problematic how would you translate that into our language?

b. How did you learn what you have learned?

c. How do you teach others what you know?

5. Based on my interpretation of Indigenous methodology literature an Indigenous methodology stresses the value of Indigenous knowledge, attempts to collect data using an Indigenous language, uses Indigenous methods to collect data, analyses data with a method that stresses the value of Indigenous perceptions, and uses the information in accordance with the wishes of the people at the centre of the project. Do you feel that this is how the Nehinuw gather knowledge?

a. I will be using interviews and sharing circles to gather the information for this project how do you think that fits with the Nehinuw view on how we gather information?

Governance questions:

6. How does governance translate into Nehinuw?

a. How does Nehinuw traditional knowledge translate into policy?

b. How has the Nehinuw governance worked traditionally?

c. How has that Nehinuw governance changed?

7. According to the literature the policy process is the how, why, who, and when of policymaking. The traditional actors of the policy process are the state including elected officials, bureaucracy and the judiciary. These actors are involved in creating public policies such as policy, law, and legislation. In this context is there such a thing as a Nehinuw policy process?

a. How do the Nehinuw people view/define decision-making? How do the Nehinuw people conduct collective/community decision-making; policy making more broadly;

b. How would you define the Nehinuw policy making process?

c. Decision-making? Policy process? Or other?

Personal Governance Story: 
8. What is your personal governance story?

a. What can you say about your experience as a policymaker?

b. What can you tell me about your understanding of the Nehinuw policy process?

c. What motived you to become a policy-maker?

d. What types of policies have you helped to develop?

The Actors of Governance:

9. How would you describe Nehinuw governance?

a. What are the strengths of Nehinuw governance?

b. What are the challenges of Nehinuw governance?

10. Do you have any experience making policy with other Indigenous communities or political organizations (such as the Prince Albert Grand Council or the Saskatchewan Métis Council)?

a. How would you describe the governance process of other Indigenous communities or political organizations?

11. Do you have any experience making policy with business organizations (such as the Cameco)?

a. How would you describe the governance process of business organizations?

12. Do you have any experience making policy with non-profit/non-governmental organizations (such as the Canadian Diabetes Association)

a. How would you describe the governance process of non-profit organizations?

\section{Indigenous Governance}

13. As an Indigenous person, do you find that it is easy to convey your concerns to nonindigenous people when you are involved in governance?

14. Do you feel that governance works differently between different Indigenous communities?

a. If so how does it work differently?

\section{Conclusion}

Are there any additional areas that have not been covered in this interview that you would like to share? 
This study has been approved according to the recommended principles of the TriCouncil Policy Statement on the Ethical Conduct for Research Involving Humans and the policies of Ryerson University.

The Tri-Council is a policy that makes sure research is done in a good way.

If you have questions regarding your rights as a human subject and participant in this study, you may contact any of the following University Research Ethics Boards for information:

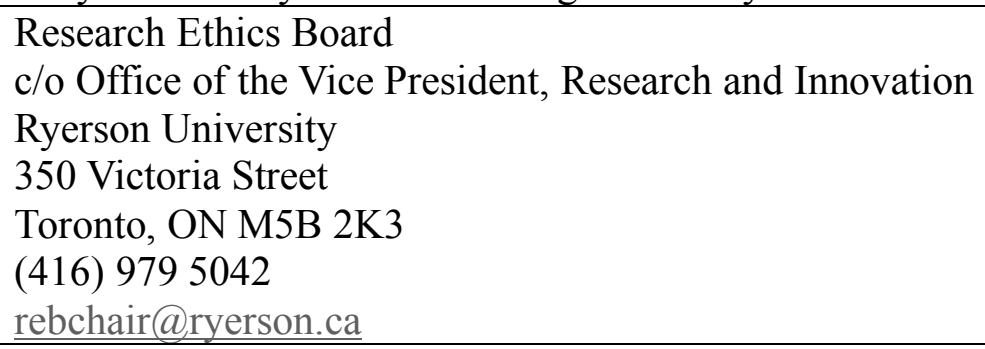




\section{Consent Form/Process}

There are two ways that you can show you want to participate. You can sign this agreement or, instead, you can accept the bundle of traditional medicines. In accepting this bundle or signing the agreement you understand what we are asking for, have asked questions about the study and agree to participate. You have been told that you can change your mind and withdraw at any time. You have been given a copy of this agreement. You have been told that by accepting this bundle or signing this consent agreement you are not giving up any of your legal rights.

Doing this project is my choice. I understand that I can withdraw for any reason at any time by contacting Real Carriere (real.carriere@,ryerson.ca or 647-460-4305).

I understand that my confidentiality will be protected with proper data storage. I know that only group data, with my approval, will be reported and published.

I understand that I will be audio-recorded during the interview.

I agree to the interview being audio-recorded

I do not agree with the interview being audio-recorded accepted traditional medicine bundle in place of signed consent

I understand the confidentiality procedures of this project.

I would like to to be recognized as a source for my participation in this project.

I would like my identity to remain confidential.

Name of Participant (please print)

Signature of Participant

Date 


\section{Appendix E: Traditional Gathering Places}

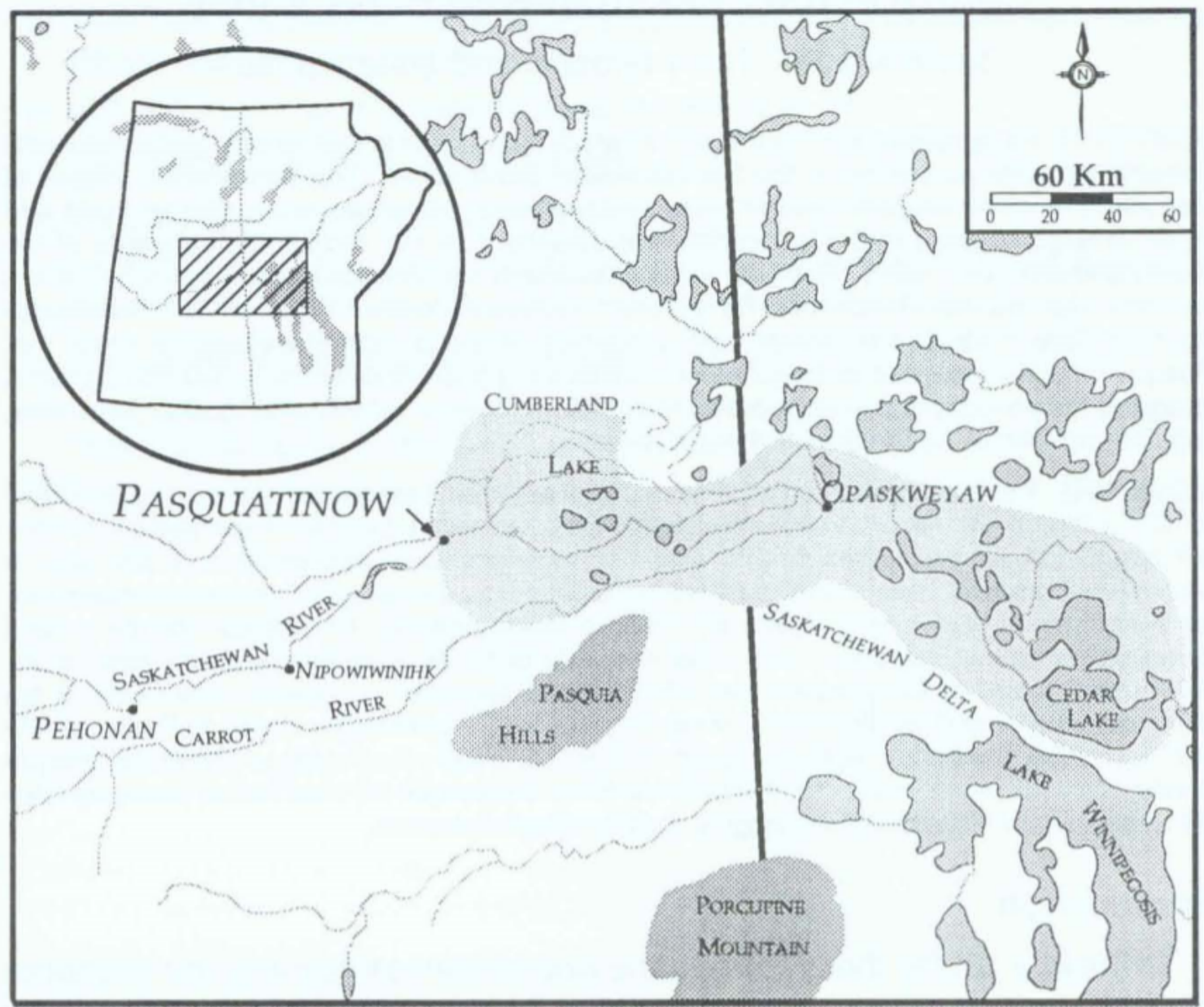

Figure 1. The Saskatchewan River valley, showing the extent of the Saskatchewan River delta. Some Cree place names are also shown.

Source: Meyers, Gibson, \& Russell, 1992, p. 202 


\section{Appendix F: Additional Cree Governance Theories and Practices}

These concepts were discovered during the research for this dissertation but not

mentioned by participants.

Table 1.2. Additional Cree Governance Theories and Practices

\begin{tabular}{|c|c|}
\hline Askîwipimâcihowascikêwina & $\begin{array}{l}\text { Setting into place arrangements for livelihood. (Cardinal \& } \\
\text { Hildebrandt, 2000, p.78). }\end{array}$ \\
\hline Atoskewimahcihowin & A desire to work (Cardinal \& Hildebrandt, 2000, p.78). \\
\hline E-miciminitomakahki & They are interconnected (Cardinal \& Hildebrandt, 2000, p.78). \\
\hline E-witaskemacik & $\begin{array}{l}\text { They live harmoniously and peaceful with them (Cardinal \& } \\
\text { Hildebrandt, 2000, p. } 78 \text { ). }\end{array}$ \\
\hline Itasowét & $\begin{array}{l}\text { To govern, to make laws, enforcing laws (Pratt, Bone, \& The } \\
\text { Treaty and Dakota Elders of Manitoba, 2014) }\end{array}$ \\
\hline Iteyimikosiwiyecikewina & $\begin{array}{l}\text { Agreements inspired by the creator (Cardinal \& Hildebrandt, } \\
2000, \text { p.78). }\end{array}$ \\
\hline Iyiniw miyikowisowina & $\begin{array}{l}\text { What has been given to the people (Cardinal \& Hildebrandt, } \\
2000, \text { p.78). }\end{array}$ \\
\hline Iyiniw Pahminsowin & Governance (Makokis, 2000). \\
\hline Inyniwak & $\begin{array}{l}\text { People made by a healthy land (Cardinal \& Hildebrandt, 2000, } \\
\text { p.78). }\end{array}$ \\
\hline Kakayiwatisiwin & $\begin{array}{l}\text { The desire to be hardworking (Cardinal \& Hildebrandt, 2000, } \\
\text { p.78). }\end{array}$ \\
\hline Kakeskihkemowina & Teachings (Cardinal \& Hildebrandt, 2000, p.78). \\
\hline Kichi-asotamatowin & $\begin{array}{l}\text { Sacred promised to one another (Cardinal \& Hildebrandt, } \\
2000, \text { p.79). }\end{array}$ \\
\hline Kisewatisiwin & Kindness, to be kind (Cardinal \& Hildebrandt, 2000, p.79). \\
\hline Kwayaskatisiwin & Honesty and fairness (Cardinal \& Hildebrandt, 2000, p.79). \\
\hline Manacihitowin & $\begin{array}{l}\text { The act of treating each other with respect (Cardinal \& } \\
\text { Hildebrandt, 2000, p.79). }\end{array}$ \\
\hline Manatisiwin & $\begin{array}{l}\text { The act of being respectful (Cardinal \& Hildebrandt, 2000, } \\
\text { p.79). }\end{array}$ \\
\hline Manitow Wiyinikewina & Nêhiyaw Legal system (McAdam, 2015, p.38). \\
\hline Mamitoneyihcikan & Mind, intellect (Cardinal \& Hildebrandt, 2000, p.79). \\
\hline Miskâsowin & $\begin{array}{l}\text { Finding one's sense of origin (Cardinal \& Hildebrandt, 2000, } \\
\text { p.79). }\end{array}$ \\
\hline Miyo-wîcêhtowin & $\begin{array}{l}\text { Translates into "having good relations" and refers to the Cree } \\
\text { principle that requires that "individuals and nations conduct } \\
\text { themselves in a manner that they create positive relationships" } \\
\text { (Cardinal \& Hildebrandt, 2000, p.14). }\end{array}$ \\
\hline Nahasiwin & Ability to develop alert and discerning faculties \\
\hline Nahihtamowin & $\begin{array}{l}\text { Ability to develop a keen sense of hearing (Cardinal \& } \\
\text { Hildebrandt, 2000, p.79). }\end{array}$ \\
\hline Nêhiyaw Wiyasiwewina & Human laws (McAdam, 2015, p.23). \\
\hline
\end{tabular}




\begin{tabular}{|l|l|}
\hline Okihcitawiskwewak & Traditional role of women (McAdam, 2015, p.24). \\
\hline $\begin{array}{l}\text { Okimâw miyo- } \\
\text { wichitowiyecikewin witaske- } \\
\text { osihcikewin }\end{array}$ & $\begin{array}{l}\text { an agreement between the sovereign leaders to establish good } \\
\text { relations and to live together in peace (Cardinal \& Hildebrandt, } \\
\text { 2000, p.33). }\end{array}$ \\
\hline Onikaniwak & Headman (McAdam, 2015, p.80). \\
\hline Oskapewisak & Elders' helpers (Cardinal \& Hildebrandt, 2000, p.79). \\
\hline Oskapews & Which are "sacred helpers" (McAdam, 2015, p.17). \\
\hline Pimatisiwin & $\begin{array}{l}\text { Refers to the spiritual, physical, and economic connection to } \\
\text { the land and the ability to make a living (Cardinal \& } \\
\text { Hildebrandt, 2000, p.43). }\end{array}$ \\
\hline Tapwewin & $\begin{array}{l}\text { Speaking the truth with precision and accuracy (Cardinal \& } \\
\text { Hildebrandt, 2000, p.80). }\end{array}$ \\
\hline Tipahamatowin & $\begin{array}{l}\text { Teaching each other commensurately (Cardinal \& Hildebrandt, } \\
\text { 2000, p.80). }\end{array}$ \\
\hline Wanascikatek & $\begin{array}{l}\text { Being set up, self-government laws (Pratt, Bone, \& The Treaty } \\
\text { and Dakota Elders of Manitoba, 2014). }\end{array}$ \\
\hline Witaskewin & $\begin{array}{l}\text { Is an agreement to live together and within the treaty context } \\
\text { refers to entering into agreements to share the land (Cardinal \& } \\
\text { Hildebrandt, 2000, p.39). }\end{array}$ \\
\hline Witaske-osihcikewin & $\begin{array}{l}\text { Agreement or arrangement to live together in peace and } \\
\text { harmony (Cardinal \& Hildebrandt, 2000, p.80). }\end{array}$ \\
\hline
\end{tabular}




\section{References}

Abele, F. (2007a). Between respect and control: Traditional Indigenous knowledge in Canadian public policy. In M. Orsini \& M. Smith (Eds.), Critical Policy Studies (pp. 233-256). Vancouver, BC: UBC Press.

Abele, F. (2007b). Like an ill-fitting boot: Government, governance and management systems in the contemporary Indian Act (Research Paper). Ottawa, ON: National Centre for First Nations Governance. Retrieved from http://fngovernance.org/resources_docs/Analysis_of_Governance_and_Management_Un der_the_Indian_Act.pdf

Abele, F., \& Prince, M. J. (2006). Four pathways to Aboriginal self-government in Canada. American Review of Canadian Studies, 36(4), 568-597. Retrieved from http://journals1.scholarsportal.info/details/02722011/v36i0004/568_fptasic.xml

Abigosis, B. (2003). Seeking a double understanding: Constituting local First Nations governance (Doctoral Dissertation). Retrieved from ProQuest (ISBN: 0-612-83542-1)

Aboriginal Affairs and Northern Development Canada. (2013). The government of Canada's approach to implementation of the inherent right and the negotiation of Aboriginal selfgovernment. Ottawa, ON: Aboriginal Affairs and Northern Development Canada. Retrieved from http://www.aadnc-aandc.gc.ca/eng/1100100031843/1100100031844 Aboriginal Justice Inquiry of Manitoba. (1999). Report of the Aboriginal justice inquiry of Manitoba-Chapter 5 - Aboriginal and Treaty Rights. Winnipeg, MB: Aboriginal Justice Inquiry of Manitoba. Retrieved from http://www.ajic.mb.ca/volumel/chapter5.html

Absolon, K. E. (2011). Kaandossiwin: How we come to know. Halifax, NS: Fernwood Publishing. 
Absolon, K., \& Willett, C. (2004). Aboriginal research: Berry picking and hunting in the 21 st Century. First Peoples Child \& Family Review, 1(1), 5-17. Retrieved from http://journals.sfu.ca/fpcfr/index.php/FPCFR/article/view/5

Absolon, K., \& Willett, C. (2005). Putting ourselves forward: Location in Aboriginal research. In L. Brown \& S. Strega. (Eds.), Research as resistance: Critical, Indigenous, \& antioppressive approaches (pp.97-126). Toronto, ON: Canadian Scholars Press.

Adams, H. (1989). Prison of grass: Canada from a native point of view (Rev. ed.). Saskatoon, SK: Fifth House Publishers.

Ahenakew, F. (1987). Cree language structures: A Cree approach. Winnipeg, MB: Pemmican Publications Inc.

Alcantara, C. (2003). Individual property rights on Canadian Indian reserves: The historical emergence and jurisprudence of certificates of possession. Canadian Journal of Native Studies, 23(2), 391-424.

Alcantara, C. (2007). Reduce transaction costs? Yes. Strengthen property rights? Maybe: The First Nations land management Act and economic development on Canadian Indian reserves. Public Choice, 132, 421-432. doi: 10.1111/j.1754-7121.2008.00020.x

Alcantara, C., \& Nelles, J. (2014). Indigenous peoples and the state in settler societies: Toward a more robust definition of multilevel governance. Publius, 44(1), 183-204. doi: 10.1093/publius/pjt013

Alcantara, C., \& Whitfield, G. (2010). Aboriginal self-government through constitutional design: A survey of fourteen Aboriginal constitutions in Canada. Journal of Canadian Studies/Revue d'Études Canadiennes, 44(2), 122-145. Retrieved from Project Muse. 
Alexie, E. D. (2011). “Nakhwanh Gwich'in Khehłok Iidilii - we are our own people” Teett'it Gwich'in practices of indigeneity: Connection to land, traditional self-governance, and elements of self determination (Master's Thesis). Retrieved from www.academic.edu

Alfred, G. R. (1995). Heeding the voices of our ancestors: Kahnawake Mohawk politics and the rise of native nationalism. Toronto, ON: Oxford University Press.

Alfred, T. (2001). From sovereignty to freedom: Towards an Indigenous political discourse. Indigenous Affairs, 3, 22-34.

Alfred, T. (2005). Wasáse: Indigenous pathways of action and freedom. Toronto, ON: Broadview Press.

Alfred, T. (2009a). Peace, power, righteousness: An Indigenous manifesto (2 ${ }^{\text {nd }}$ ed.). Oxford, UK: Oxford University Press.

Alfred, T. (2009b). Colonialism and state dependency. Journal of Aboriginal Health, 5, 42-60. Retrieved from http://www.naho.ca/jah/english/jah05_02/V5_I2_Colonialism_02.pdf

Alfred, T. (2015). Cultural strength: Restoring the place of Indigenous knowledge in practice and policy. Australian Aboriginal Studies, 2015(1), 3-11. Retrieved from http://go.galegroup.com.ezproxy.lib.ryerson.ca/ps/i.do?p=AONE\&u=rpu_main\&id=GAL $\mathrm{E} \%$ 7CA424620327\&v=2.1\&it=r\&sid=summon\&userGroup=rpu_main\&authCount=1

Alfred, T., \& Corntassel, J. (2005). Being Indigenous: Resurgences against contemporary colonialism. Government and Opposition, 40(4), 597-614. doi: 10.1111/j.14777053.2005.00166.x

Altamirano-Jiménez, I. (2008). The colonization and decolonization of Indigenous diversity. In L. Simpson (Ed.), Lighting the eighth fire: The liberation, resurgence, and protection of Indigenous nations (pp. 175-186). Winnipeg, MB: Arbeiter Ring Publishing. 
American Psychological Association. (2010). Publication Manual of the American Psychological Association (6 ${ }^{\text {th }}$ ed.). Washington DC: American Psychological Association

Amnesty International. (2012). Open letter urging a meeting with Chief Theresa Spence. Toronto, ON: Amnesty International. Retrieved from http://www.amnesty.ca/news/openletters/open-letter-urging-a-meeting-with-chief-theresa-spence

Andersen, C. (2014). 'Métis': Race, recognition, and the struggle for Indigenous peoplehood. Vancouver, BC: UBC Press. Retrieved from ProQuest.

Âpihtawikosisân. (2012). No justice, no peace [Blog post]. Retrieved from http://apihtawikosisan.com/2012/01/no-justice-no-peace/

APTN National News. (February, 7, 2015). Saskatchewan premier against resource revenue sharing with First Nations. Retrieved from http://aptn.ca/news/2015/02/07/saskatchewanpremier-resource-revenue-sharing-first-nations/

Asch, M. (2014). On being here to stay: Treaties and Aboriginal rights in Canada. Toronto, ON: University of Toronto Press.

Assembly of First Nations. (2005). Our nations, our governments: Choosing our own paths (Final Report). Ottawa, ON: Assembly of First Nations. Retrieved from http://64.26.129.156/cmslib/general/FNG\%20report_Eng\%20final.pdf

Association of Iroquois and Allied Indians. (1971). Position Paper. Brantford, ON: Association of Iroquois and Allied Indians.

Atkinson, R., \& Flint, J. (2004) Snowball sampling. In M. S., Lewis-Beck, A. Bryman \& T. Futing Liao (Eds.), The SAGE encyclopedia of social science research methods. SAGE Publications Ltd doi: 10.4135/9781412950589 
Baird, K., Davis, C., \& Madden, J. (2016). Modern day treaties fundamentally reshaping Canada for the better. CBC News. Retrieved from http://www.cbc.ca/news/Aboriginal/modernday-treaties-reshaping-canada-1.3440267

Baptiste, E. (2007, June). Traditional Governance: A Case Study of the Osoyoos Indian Band and Application of Okanagan Leadership Principles. Paper presented at Sharing Indigenous Wisdom International Conference, Green Bay, WI.

Baringer, S.K. (1997). Indian activism and the American Indian Movement: A bibliographical essay. American Indian Culture and Research Journal 21(4), 217-250. doi: https://doi.org/10.17953/aicr.21.4.j31021k578k84h24

Barker, A. J. (2009). The contemporary reality of Canadian imperialism: Settler colonialism and the hybrid colonial state. American Indian Quarterly, 33(3), 325-351. doi: 10.1353/aiq.0.0054

Barris, T. (1977). Fire canoe: Prairie steamboat days revisited. Toronto, ON: McClelland and Stewart.

Barron, F. L. (1988). The Indian Pass System in the Canadian West, 1882-1935. Prairie Forum, 13(1), 25-42. Retrieved from http://iportal.usask.ca/docs/Prairie\%20Forum/The\%20Indian\%20Pass\%20System\%20(v1 3no1_1988_pg25-42).pdf

Battiste, M. (1997). Nikanikinútmaqn. In J. S. Y. Henderson (ed). The Mikmaw Concordat. (pp. 13-20). Halifax, NS: Fernwood Publishing.

Battiste, M. (2000). Introduction: Unfolding the Lessons of Colonization. In M. Battiste (Ed.), Reclaiming Indigenous voice and vision (pp. xvi-xxx). Vancouver, BC: UBC Press. 
Battiste, M. (2016). Narrating Mi'kmaw treaties: Linking the past to the future. In M. Battiste (Ed.), Living treaties: Narrating Mi'kmaw treaty relations (pp. 1-16). Sydney, NS: Cape Breton University Press.

Battiste, M., \& Henderson, J.Y. (2000). Protecting Indigenous knowledge and heritage: A global challenge [Kindle version]. Retrieved from Amazon.com. Saskatoon, SK: Purich Publishing Ltd.

Beatty, B. B. (2006). Pimacesowin (To make your own way): First Nation governance through an autonomous non-government organization - The experience of the Peter Ballantyne Cree Nation health services inc. in Northern Saskatchewan (Doctoral Dissertation). Retrieved from ProQuest.

Belanger, Y.D. (2005). Seeking a seat at thetTable: A brief history of Indian political organizing in Canada, 1870-1951 (Doctoral Dissertation). Retrieved from https://www.uleth.ca/dspace/handle/10133/701

Belanger, Y. D. (2008). Future prospects for Aboriginal self-government in Canada. In Y.D. Belanger (Ed.), Aboriginal self-government in Canada: Current trends and issues (3rd ed., pp. 395-414). Saskatoon, SK: Purich Publishing.

Belanger, Y. D. (2011). The United Nations declaration on the rights of Indigenous peoples and urban Aboriginal self-determination in Canada: A preliminary assessment. Aboriginal Policy Studies, 1(1), 132-161. Retrieved from http://ejournals.library.ualberta.ca/index.php/aps/1/1/Belanger.pdf

Belanger, Y. (2014). Ways of knowing: An introduction to Native Studies in Canada (2nd Ed.). Toronto, ON: Nelson Education Ltd. 
Belanger, Y. D., \& Newhouse, D. R. (2004). Emerging from the shadows: The pursuit of Aboriginal self-government to promote Aboriginal well-being. Canadian Journal of Native Studies, 24(1), 129-222.

Belanger, Y. D. \& Newhouse, D. R. (2008). Reconciling solitudes: A critical analysis of the selfgovernment ideal. In Y.D. Belanger (Ed.), Aboriginal self-government in Canada: Current trends and issues (3rd ed., pp. 1-19). Saskatoon, SK: Purich Publishing. Berkes, F. (2012). Sacred ecology ( $3^{\text {rd }}$ ed., Kindle version). Retrieved from Amazon.com. New York, NY: Routledge Publishing.

Bevir, M. (2010). Democratic governance. Princeton NJ: Princeton University Press.

Bevir, M. (2012). Governance: A very short introduction. Oxford, UK: Oxford University Press. Bicentennial Committee of Cumberland House. (1974). A History of Cumberland House as told by its own citizens 1774-1974.

Birkland, T. A. (2011). An introduction to the policy process: Theories, concepts, and models of public policy making. New York, NY: M. E. Sharpe.

Blackburn, C. (2009). Differentiating Indigenous citizenship: Seeking multiplicity in rights, identity, and sovereignty in Canada. American Ethnologist, 36(1), 66-78.

Blackstock, C. (2012). Jordan's Principle: Canada's broken promise to First Nations children? Paediatrics \& Child Health, 17(7), 368-370. Retrieved from https://www-ncbi-nlm-nihgov.cyber.usask.ca/pmc/articles/PMC3448536/pdf/pch17368.pdf

Blakeney, A., \& Borins, S. (1998). Political management in Canada (2 ${ }^{\text {nd }}$ ed.). Toronto, ON: University of Toronto Press. 
Boldt, M., \& Long, J. A. (1984). Tribal traditions and European-Western political ideologies: The dilemma of Canada's Native Indians. Canadian Journal of Political Science/Revue Canadienne De Science Politique, 17(3), 537-553. doi:10.1017/S0008423900031905

Bonney, R. A. (1977). The role of AIM leaders in Indian nationalism. American Indian Quarterly, 3(3), 209-224. Retrieved from http://www.jstor.org/stable/pdf/1184538.pdf

Borrows, J. (1994). Constitutional law from a First Nation perspective: Self-government and the royal proclamation. UBC Law Review, 28(1), 1-47. Retrieved from HeinOnline.

Borrows, J. (1997). Wampum at Niagara: The royal proclamation, Canadian legal history, and self-government. In M. Asch (Ed.), Aboriginal and treaty rights in Canada: Essays on law, equality, and respect for difference (pp. 155-172). Vancouver, BC: University of British Columbia Press.

Borrows, J. (1998). Frozen rights in Canada: Constitutional interpretation and the trickster. American Indian Law Review, 22(1), 37-64.

Borrows, J. (2001). Indian agency: Forming First Nations law in Canada. PoLAR, 24(2), 9-24. Retrieved from HeinOnline.

Borrows, J. (2002). Recovering Canada: The resurgence of indigenous law. Toronto, ON; University of Toronto Press.

Borrows, J. (2005). Tracking trajectories: Aboriginal governance as an Aboriginal right. UBS Law Review, 38(2), 285-314. Retrieved HeinOnline.

Borrows, J. (2008). Seven generations, seven teachings: Ending the Indian Act (Research Paper). Vancouver, BC: National Centre for First Nations Governance. Retrieved from http://fngovernance.org/resources_docs/7_Generations_7_Teachings.pdf 
Borrows, J. (2010). Canada's Indigenous constitution (Kindle Edition). Toronto, ON; University of Toronto Press.

Borrows, J. (2015). The durablity of Terra Nullius: Tsilhqot' in Nation v British Columbia. UBC Law Review, 48(3), 701-742. Retrieved from HeinOnline.

Borrows, J. \& Rotman, L. I. (1997). The Sui Generis nature of Aboriginal rights: Does it make a difference? Alberta Law Review, 36(1), 9-45. Retrieved from HeinOnline.

Brightman, R. (1993). Grateful prey: Rock Cree human-animal relationships. Berkley, CA: University of California Press.

Brightman, R. (2007). Acadohkiwina and Achimowina: Traditional narratives of the Rock Cree indians. Regina, SK: University of Regina Press.

Broadhead, L. (2012). Canadian sovereignty versus northern security: The case for updating our mental map of the Arctic. International Journal, 65(4), 913-930.

Cairns, A. (2000). Citizens plus: Aboriginal peoples and the Canadian state. Vancouver, BC: UBC Press.

Cairns, A. (2005). Kenneth Lysyk, the Hawthorn report, and "The unique constitutional position of the Canadian Indian". UBC Law Review, 38(2), 275-284. Retrieved from LexisNexis Academic.

Cairns, H. A. C., Jamieson, S. M., and Lysyk, K. (1966). A survey of the contemporary Indians of Canada: a Report on Economic, Political, Educational Needs and Policies. [Volume 1 Publication No. QS-0603-020-EE-A-18]. Ed. H.B. Hawthorn. Ottawa, ON: Indian Affairs. Retrieved from http://caid.ca/HawRep1a1966.pdf

Calder et al. v. Attorney-General of British Columbia. (1973). S.C.R. 313. Retrieved from https://scc-csc.lexum.com/scc-csc/scc-csc/en/item/5113/index.do 
Calliou, B. (2007). Natural resources transfer agreements, the transfer of authority, and the promise to protect the first nations' right to a traditional livelihood: A critical legal history. Review of Constitutional Studies, 12(2), 173-213.

Campbell v. British Columbia (Attorney General), (2000) 4 C.N.L.R. 1 (B.C.S.C.). Retrieved from

https://www.canlii.org/en/bc/bcsc/doc/2000/2000bcsc1123/2000bcsc1123.html?searchUrl Hash=AAAAAQAPMjAwMCBCQ1NDIDExMjMgAAAAAAE

Canadian Human Rights Tribunal. (2016). Canadian Human Rights Tribunal issues a second compliance order against the government of Canada on the First Nations child welfare case. Retrieved from https://fncaringsociety.com/sites/default/files/2016\%20CHRT\%2016\%20-\%20September $\% 2015 . p d f$

Canadian Institutes of Health Research, Natural Sciences and Engineering Research Council of Canada, and Social Sciences and Humanities Research Council of Canada. (2014). TriCouncil Policy Statement: Ethical Conduct for Research Involving Humans. Retrieved from http://www.pre.ethics.gc.ca/pdf/eng/tcps2-2014/TCPS_2_FINAL_Web.pdf

Canadian Institutes of Health Research, Natural Sciences and Engineering Research Council of Canada, and Social Sciences and Humanities Research Council of Canada. (2017). Panel on research ethics. Retrieved from http://www.pre.ethics.gc.ca/eng/index/

Canadian Press. (August 13, 2016). 'Racial tension' in Sask. after First Nations man shot dead while looking for flat tire help on farm, family says. Toronto, ON: Canadian Press. Retrieved from http://news.nationalpost.com/news/canada/racial-tension-in-sask-afterfirst-nations-man-shot-dead-while-looking-for-flat-tire-help-on-farm-family-says 
Cardinal, H. (1969). The Unjust Society. Vancouver, BC: Douglas \& McIntyre.

Cardinal, H., \& Hildebrandt, W. (2000). Treaty Elders of Saskatchewan: Our dream is that our peoples will one day be clearly recognized as nations. Calgary, AB: Calgary University Press.

Casey, A. (December 1, 2013). Hope for the Saskatchewan River Delta? Ottawa, ON: Canadian Geographic. Retrieved from https://www.canadiangeographic.ca/article/hopesaskatchewan-river-delta

Castellano, M. B. (2004). Ethics of Aboriginal research. Journal of Aboriginal Health, 1(1), 98114.

Charmaz, K., \& Bryant, A. (2008). Grounded theory. In L. M. Given (Ed.), The SAGE encyclopedia of qualitative research methods. Thousand Oaks, CA: SAGE Publications Ltd doi: $10.4135 / 9781412963909$

Charter of the United Nations. (1945). Chapter XI: Declaration regarding non-self-governing territories. New York, NY: United Nations. Retrieved from http://www.un.org/en/sections/un-charter/chapter-xi/

Chartrand, L. (2008). “We Rise Again:” Métis traditional governance and the claim to Métis self-government. In Y.D. Belanger (Ed.), Aboriginal self-government in Canada: Current trends and issues (3rd ed., pp. 145-157). Saskatoon, SK: Purich Publishing.

Chilisa, B. (2012). Indigenous research methodologies. Los Angeles, CA: SAGE Publishing. Christian, K. W. (2009). Towards recognition of our inherent rights as Indigenous peoples (Report). West Vancouver, BC: First Nation Summit. Retrieved from http://www.fns.bc.ca/pdf/TowardsRecognition_WChristian.pdf 
Christie, G. (2007). Aboriginal nationhood and the inherent right to self-government (Research Paper). Vancouver, BC: National Centre for First Nations Governance. Retrieved from http://fngovernance.org/ncfng_research/gordon_christie.pdf

Coates, K. (2008). The Indian Act and the future of Aboriginal governance in Canada (Research Paper). Vancouver, BC: National Centre for First Nations Governance. Retrieved from http://fngovernance.org/ncfng_research/coates.pdf

Coates, K. S. \& Morrison, W. R. (1986). Treaty research report treaty five 1875. Ottawa, ON: Treaties and Historical Research Centre Indian and Northern Affairs Canada.

Cohen, M. D., March, J. G., \& Olsen, J. P. (1972). A garbage can model of organizational choice. Administrative Science Quarterly, 17, 1-25.

Constitution Act. (1982). Ottawa, ON: Department of Justice. Retrieved from Department of Justice. http://laws-lois.justice.gc.ca/eng/Const/page-16.html\#h-52

Cooke, M., \& McWhirter, J. (2011). Public policy and Aboriginal peoples in Canada: Taking a life-course perspective. Canadian Public Policy, 37(Supplement), 15-31. doi: 10.3138/cpp.37.suppl.s15

Coon Come, M. (1995). Aboriginal voices. In B.W. Hodgins \& K.A. Cannon (Eds.), On the land: Confronting the challenges to Aboriginal self-determination in Northern Quebec \& Labrador (pp.1-17). Toronto, ON: Betelegeuse Books.

Cornell, S., \& Kalt, J. P. (1998). Sovereignty and nation-building: The development challenge in Indian country today. American Indian Culture and Research Journal, 22(3), 187-214.

Cornell, S., \& Taylor, J. B. (2000). Sovereignty, devolution, and the future of tribal-state relations. Malcolm Weiner Centre for Social Policy. Retrieved from http://hpaied.org/images/resources/publibrary/PRS00-4.pdf 
Corntassel, J. (2003). Who is Indigenous? 'Peoplehood' and ethnonationalist approaches to rearticulating Indigenous identity. Nationalism and Ethnics Politics, 9(1), 75-100. doi: $10.1080 / 13537110412331301365$

Corntassel, J. (2012a). Living in a Longer Now: Moving Beyond the State-Centric System. In Waziyatawin and M. Yellow Bird (Eds.), For Indigenous Minds Only: A Decolonization Handbook. Santa Fe, NM: School for Advanced Research Press.

Corntassel, J. (2012b). Re-envisioning resurgence: Indigenous pathways to decolonization and sustainable self-determination. Decolonization: Indigeneity, Education \& Society, l(1), 86-101.

Corntassel, J., \& Primeau, T. H. (1995). Indigenous "sovereignty" and international law: Revised strategies for pursuing "self-determination". Human Rights Quarterly, 17(2), 343-365. doi: 10.1353/hrq.1995.0015

Coté, C. (2001). Historical foundations of Indian sovereignty in Canada and the United States: A brief overview. The American Review of Canadian Studies, 31(1), 15-23. doi: $10.1080 / 02722010109481579$

Coulthard, G. S. (2014). Red skins, white masks: Rejecting the colonial politics of recognition. (Kindle Edition). Minneapolis, MN: University of Minnesota Press.

Crane, B. A., Mainville R., \& Mason, M. W. (2008). First Nations governance law. Markham, ON: LexisNexis Butterworth's.

Creswell, J. W. (2009). Research design: Qualitative, quantitative, and mixed methods approaches ( $3^{\text {rd }}$ Ed.). Los Angeles, CA: Sage Publishing.

Creswell, J. W. (2013). Qualitative inquiry \& research design: Choosing among five approaches. Los Angeles, CA: Sage Publishing. 
Cumberland House Cree Nation. (2015). Cumberland House Cree Nation. Retrieved from http://chen.ca/

Dacks, G. (2004). Implementing First Nations self-government in Yukon: Lessons for Canada. Canadian Journal of Political Science. 37(3), 671-694. doi:

$10.1017 / \mathrm{S} 0008423904030367$

Daes, E-I. (1994). Preliminary report of the special rapporteur: Protection of the peritage of Indigenous Peoples. E/CN.4/Sub.2/1994/31.Sub-Commission on Prevention of Discrimination and Protection of Minorities, Commission on Human Rights, UNESCO. Retrieved from http://cwis.org/GML/UnitedNationsDocuments/

Dallimore, E. J. (2000). A feminist response to issues of validity in research. Women's Studies in Communication. 23(2), 157-181.

Dalton, J. E. (2006). Aboriginal self-determination in Canada: Protections afforded by the judiciary and government. Canadian Journal of Law and Society, 21, 11-37.

Daniels, H. W. (1998). Bill C-31: The Abocide Bill (Report). Ottawa, ON: Congress of Aboriginal Peoples.

Daniels v. Canada (Indian Affairs and Northern Development). (2016). SCC 12, [2016] 1 S.C.R. 99. Retrieved from https://scc-csc.lexum.com/scc-csc/scc-csc/en/item/15858/index.do

Darcy, S. (2004). The evolution of the department of Indian affairs' central registry recordkeeping systems: 1872-1984. Archivaria, 58, 161-171. Retrieved from http://journals.sfu.ca/archivar/index.php/archivaria/article/view/12482/13598

Davis, M. (2008). Indigenous struggles in standard-setting: The United Nations declaration on the rights of Indigenous peoples. Melbourne Journal of International Law, 9(2), 439-471. 
Decker, J. F. (1988). Tracing historical diffusion patterns: The case of the 1780-82 smallpox epidemic among the Indians of Western Canada. Native Studies Review, 4(1), 1-24.

Delgamuukw v. British Columbia. (1997). 3 S.C.R. 1010. Retrieved from https://scccsc.lexum.com/scc-csc/scc-csc/en/1569/1/document.do

Deloria Jr., V. (1969). Custer dies for your sins: An Indian manifesto. New York, NY: Macmillan Publishing.

Deloria Jr., V. (1972). God is red: A native view of religion. Golden, CO: Fulcrum Publishing.

Deloria Jr., V. (1997). Red earth, white lies: Native Americans and the myth of scientific fact. Golden, CO: Fulcrum Publishing.

Dempsey, H. A. (2006). Big Bear: End of freedom. Vancouver, BC: Douglas \& McIntyre.

Diabo, R. (2004). All party support to ram Bill C-20 through Parliament: Imposes 'fiscal institutions' and property tax on-reserve. First Nations Strategic Bulletin, 2(11), Retrieved from http://epe.lacbac.gc.ca/100/201/300/first_nations_strategic_bulletin/2004/v02n11.pdf

Diabo, R. (2013). Idling some more: AFN \& 100's of Chiefs capitulate to Harper's termination plan. First Nations Strategic Bulletin, 11(1-9), Retrieved from http://epe.lacbac.gc.ca/100/201/300/first_nations_strategic_bulletin/2013/v11n01-09.pdf

Diabo, R. (2016). Trudeau Government's Approach to "Reconciliation" for Completion of Confederation on Canada's 150th Anniversary. First Nations Strategic Bulletin, 14(8-12), Retrieved from http://epe.lacbac.gc.ca/100/201/300/first_nations_strategic_bulletin/2016/v14n08-12.pdf

Dickason, O. (2010). A concise history of Canada's First Nations. Toronto, ON: Oxford University Press. 
Dorion, L. \& Paquin,T. (2003). Cumberland House. Saskatoon, SK: Gabriel Dumont Institute. Retrieved from www.metismuseum.ca/resource.php/00717

Doxtater, T. M. (2011). Putting the theory of Kanataron:non into practice: Teaching Indigenous governance. Action Research, 9(4), 385-404. doi:10.1177/1476750311409766

Dunleavy, P. (2003). Authoring a PhD: How to plan, draft, write, and finish a doctoral thesis or dissertation. New York. NY: Palgrave Macmillan.

Ellingson, L. L. (2011). Analysis and representation across the continuum. In N. K. Denzin \& Y. S. Lincoln (Eds.), Handbook of qualitative research. (4 ${ }^{\text {th }}$ Ed., pp. 595-610). Thousand Oaks, CA: Sage.

Environics Institute for Survey Research. (2016a). Canadian public opinion on Aboriginal peoples. Toronto, ON: Environics Institute for Survey Research. Retrieved from http://www.environicsinstitute.org/uploads/instituteprojects/canadian\%20public\%20opinion\%20on\%20aboriginal\%20peoples\%202016\%20\%20final\%20report.pdf

Environics Institute for Survey Research. (2016b). Canadian public opinion on governance. Toronto, ON: Environics Institute for Survey Research. Retrieved from http://www.environicsinstitute.org/uploads/instituteprojects/canadian\%20public\%20opinion\%20on\%20governance $\% 202016 \% 20-\% 20$ final $\%$ 20report\%20-\%20june\%2017-2016.pdf

Ermine, W., Sinclair, R., \& Jeffery, B. (2004). The ethics of research with Indigenous people. Report prepared for the interagency advisory panel on research ethics. Saskatoon, SK: Indigenous Peoples' Health Research Centre. Retrieved from http://ahrnets.ca/files/2010/05/ethics_review_iphrc.pdf 
Evans, B. M., \& Shields J. (2010). The third sector and the provision of public good: Partnerships, contracting and the neo-liberal state. In C. Dunn (Ed.), The Handbook of Canadian Public Administration (pp. 305-318). Oxford, UK: Oxford University Press.

Fanon, F. (1963). The wretched of the earth. New York, NY: Grove Press.

Fanon, F. (1967). Black skins, White masks. New York, NY: Grove Press.

Federation of Saskatchewan Indian Nations. (2015). Treaty governance overview. Saskatoon, SK: Federation of Saskatchewan Indian Nations. Retrieved from http://www.fsin.com/index.php/treaty-governance

Fenton, W. N. (1998). The great law and the longhouse: A political history of the Iroquois confederacy. Norman, OK: Oklahoma Press.

First Nations Centre. (2007). OCAP: Ownership, control, access and possession. Sanctioned by the First Nations Information Governance Committee, Assembly of First Nations. Ottawa, ON: National Aboriginal Health Organization.

First Nations Elections Act. (2014). S.C. 2014, c.5. Retrieved from http://laws.justice.gc.ca/eng/acts/F-11.65/page-1.html

First Nations Financial Transparency Act. (2013). S.C. 2013, c.7. Retrieved from http://lawslois.justice.gc.ca/eng/acts/F-11.66/page-1.html

First Nations Fiscal Management Act. (2005). S.C. 2005, c. 9. Retrieved from http://lawslois.justice.gc.ca/eng/acts/F-11.67/page-1.html

Fitzmaurice, A. (2007). The genealogy of Terra Nullius. Australian Historical Studies, 38(129), 1-15. doi:10.1080/10314610708601228

Flanagan, T. (1983). The case against Metis Aboriginal rights. Canadian Public Policy, 9(3), 314-325. Retrieved from JStor. 
Flanagan, T. (1985). The sovereignty and nationhood of Canadian Indians: A comment on Boldt and Long. Canadian Journal of Political Science/Revue Canadienne De Science Politique, 18(2), 367-374. doi:10.1017/S0008423900030304

Flanagan, T. (2000). First Nations? Second thoughts. Montreal, QC: McGill-Queen's University Press.

Flanagan, T. \& Alcantara, C. (2004). Individual property rights on Canadian Indian reserves. Queens Law Journal, 29(2), 489-532.

Flanagan, T., Alcantara, C., \& Dressay, A. L. (2010). Beyond the Indian Act: restoring Aboriginal property rights. Montreal, QC: Mcgill-Queen’s University Press.

Fondahl, G. \& Irlbacher-Fox, S. (2009). Indigenous governance in the Arctic: A report for the Arctic governance project. Walter and Duncan Gordon Foundation. Retrieved from http://www.arcticgovernance.org/indigenous-governance-in-the-arctic.4667323142902.html

Fossett, R. (2001). In order to live untroubled: Inuit of the Central Arctic, 1550-1940. Winnipeg, MB: University of Manitoba Press.

Foster, H. (1992). Forgotten arguments: Aboriginal title and sovereignty in Canadian jurisdiction act cases. Manitoba Law Journal, 21, 343-389. Retrieve from HeinOnline.

Foster, H. (1999). Honouring the queen's flag: A legal and historical perspective on the Nisga'a treaty. BC Studies, 120, 11-36. Retrieved from ojs.library.ubc.ca/index.php/bcstudies/article/download/1475/1519

Fowler, F. J. (2009). Benefits to respondents. In Survey research methods (4 ${ }^{\text {th }}$ ed.) SAGE Research Methods. Retrieved from 
http://srmo.sagepub.com.ezproxy.lib.ryerson.ca/view/survey-researchmethods/n11.xml?rskey=m2jHy9

Francis, D. (1982). Battle for the West: Fur traders and the birth of Western Canada. Edmonton, AB: Hurting Publishers.

Frank v. The Queen, [1978] 1 S.C.R. 95. Ottawa, ON: Department of Justice. Retrieved from https://scc-csc.lexum.com/scc-csc/scc-csc/en/item/5989/index.do

Franks, C. E. S. (1986). Public administration questions relating to Aboriginal self-government. Kingston, ON: Institute of Intergovernmental Relations. Retrieved from $<$ http://www.queensu.ca/iigr/pub/archive/Aboriginalpapers/background/BG12PublicAdm inistrationQuestionsRealtingtoAboriginalSelf-Government.pdf>

Frederickson, G. F., \& Smith, K.B. (2003). Public administration theory primer. New York, NY: Westview Press.

Frideres, J. S., \& Gadacz, R. R. (2012). Aboriginal people in Canada (9 $9^{\text {th }}$ Ed.). Toronto, ON: Pearson Canada.

Friesen, J. (2016, October 16). The night Colten Boushie died: What family and police files say about his last day, and what came after. The Globe and Mail. Retrieved from http://www.theglobeandmail.com/news/national/colten-boushie/article32451940/

Gaudry, A. J. P. (2011). Insurgent research. Wicazo Sa Review, 26(1), 113-136. Retrieved from JSTOR.

Gaudry, A. \& Andersen, C. (2016). Daniels v. Canada: Racialized Legacies, Settler SelfIndigenization and the Denial of Indigenous Peoplehood. TOPIA: Canadian Journal of Cultural Studies, 36, 19-30. Retrieved from http://topia.journals.yorku.ca/index.php/topia/article/view/40396 
Gibson, G. (2009). A new look at Indian policy: Respect the collective - promote the individual. Vancouver, BC: Fraser Institute.

Given, L. M. (2008). The SAGE encyclopedia of qualitative research methods. Thousand Oaks, CA: SAGE Publications Ltd doi: 10.4135/9781412963909

Given, L. M., \& Saumure, K. (2008). Trustworthiness. In L. M. Given (Ed.), The SAGE encyclopedia of qualitative research methods. Thousand Oaks, CA: SAGE Publications Ltd doi: $10.4135 / 9781412963909$

Glaser, B. G. (1978). Theoretical sensitivity. Mill Valley, CA: Sociology Press.

Glaser, B. G., \& Strauss, A. L. (2012). The discovery of grounded theory: Strategies for qualitative research. New Brunswick, USA: AldineTransaction.

Giokas, J. (1995). The Indian act evolution, overview and options for amendment and transition (Report). Ottawa, ON: Canada Communications Group. Retrieved from http://publications.gc.ca/collections/collection_2016/bcp-pco/Z1-1991-1-41-130-eng.pdf

Goulet, K. N. (1986). Oral history as an authentic and credible research base for curriculum: The Cree of Sandy Bay and hydroelectric power development 1927-67, An Example. (Master's Thesis). Retrieved from ProQuest.

Goulet, L. M., \& Goulet, K. N. (2014). Teaching each other: Nehinuw concepts and Indigenous pedagogy. Vancouver, BC: UBC Press.

Goulet, T. (2013). Revitalizing Cree legal traditions: Cumberland House and Pelican Narrows (Master's Thesis). Retrieved From ProQuest.

Government of Canada. (2013). Canada research chair in Indigenous politics and governance. Retrieved from http://www.chairs-chaires.gc.ca/chairholders-titulaires/profileeng.aspx?profileID=2002\# 
Government of Saskatchewan. (2015). The municipality Act. Regina, SK: Government of Saskatchewan. Retrieved from http://www.qp.gov.sk.ca/documents/English/Statutes/Statutes/M36-1.pdf

Government of Saskatchewan. (2016). Municipality details. Regina, SK: Government of Saskatchewan. Retrieved from http://www.mds.gov.sk.ca/apps/Pub/MDS/muniDetails.aspx?cat=10\&mun=2607

Grammond, S. (2013). Terms of coexistence: Indigenous peoples and Canadian Law. Toronto, ON: Thomson Reuters Canada Limited.

Grbich, C. (2013). Qualitative data analysis: An introduction ( ${ }^{\text {nd }}$ ed.). London, UK: Sage Publications.

Grenier, L. (1998). Working with Indigenous knowledge: A guide for researchers. Ottawa, ON: International Development Research Centre.

Guerin v. The Queen. (1984). 2 S.C.R. 335. Retrieved from https://scc-csc.lexum.com/scccsc/scc-csc/en/item/2495/index.do

Guetterman, T. C. (2015). Descriptions of Sampling Practices Within Five Approaches to Qualitative Research in Education and the Health Sciences. Forum Qualitative Sozialforschung / Forum: Qualitative Social Research, 16(2). Retrieved from http://nbnresolving.de/urn:nbn:de:0114-fqs1502256.

Gunn, B. L. (2007). Protecting Indigenous peoples' lands: Making room for the application of Indigenous peoples' laws within the Canadian legal system. Indigenous Law Journal, 6, 31-69.

Haida Nation v. British Columbia (Minister of Forests). (2004). 3 S.C.R. 511, 2004 SCC 73. Retrieved from https://scc-csc.lexum.com/scc-csc/scc-csc/en/item/2189/index.do 
Hanson, E. (2009). Aboriginal title. Vancouver, BC: First Nations Studies Program. Retrieved from http://indigenousfoundations.arts.ubc.ca/home/land-rights/Aboriginal-title.html

Hansen, J. G. (2013). Swampy Cree Justice: Researching the Ways of the People (2nd ed.). Vernon, BC: JCharlton Publishing.

Henderson, A. (2008). Self-government in Nunavut. In Y.D. Belanger (Ed.), Aboriginal selfgovernment in Canada: Current trends and issues (3rd ed., pp. 222-239). Saskatoon, SK: Purich Publishing.

Henderson, J. S. Y. (1994). Empowering Treaty Federalism. Saskatchewan Law Review, 58, 241329.

Henderson, J. S. Y. (2002). Postcolonial Indigenous Legal Consciousness. Indigenous Law Journal, 1(Spring), 1-56.

Henderson, J. S. Y. (2006). First Nations jurisprudence and Aboriginal rights: Defining the just society. Saskatoon, SK: Native Law Centre University of Saskatchewan.

Henderson, J. S. Y. (2008a). Treaty governance. In Y.D. Belanger (Ed.) Aboriginal selfgovernment in Canada: Current trends and Issues (3rd ed., pp. 20-38). Saskatoon, SK: Purich Publishing.

Henderson, J. S. Y. (2008b). Indigenous diplomacy and the rights of peoples: Achieving UN recognition. Saskatoon, SK: Purich Publishing.

Hicks, J. (2005). Education in the Canadian Arctic: What difference has the Nunavut government made? Indigenous Affairs, 2, 8-15. Retrieved from http://www.iwgia.org/iwgia_files_publications_files/IA_1-2005.pdf

Hill, S. M. (2008). Travelling down the river of life together in peace and friendship, forever: Haudenosaunee land ethics and treaty agreements as the basis for restructuring the 
relationship with the British Crown. In L. Simpson (Ed.), Lighting the Eighth fire: The liberation, resurgence, and protection of Indigenous nations (pp. 23-46). Winnipeg, MB: Arbeiter Ring Publishing.

Hoehn, F. (2012). Reconciling sovereignties: Aboriginal nations and Canada. Saskatoon, SK: Native Law Centre University of Saskatchewan.

Horn-Miller, K. (2013). What Does Indigenous Participatory Democracy Look Like? Kahnawà:ke’s Community Decision Making Process. Review of Constitutional Studies/Revue d'études constitutionnelles, 18(1), 111-132.

Hurley, M. (2009). The Indian Act. Ottawa, ON: Library of Parliament. Retrieved from http://www.parl.gc.ca/Content/LOP/ResearchPublications/prb0912-e.pdf

Idle No More. (November 10, 2012). Idle No More is founded by 4 women. Retrieved from http://www.idlenomore.ca/idle_no_more_is_founded_by_4_women

Imai, S. (2007). The structure of the Indian Act: Accountability in governance (Research Paper). Vancouver, BC: National Centre on First Nations Governance. Retrieved from http://fngovernance.org/ncfng_research/shin_imai.pdf

Indian Act. (1985). R.S.C., c. I-5. Ottawa, ON: Department of Justice. Retrieved from http://laws-lois.justice.gc.ca/PDF/I-5.pdf

Indian Band Council Procedure Regulation. (2009). Indian Band Council Procedure Regulation. C.R.C., c. 950. Ottawa, ON: Department of Justice. Retrieved from http://lawslois.justice.gc.ca/PDF/C.R.C.,_c._950.pdf

Indian and Northern Affairs. (1978). The historical development of the Indian Act. Ottawa, ON: Treaties and Historical Research Centre. Retreived from 
http://www.kitselas.com/images/uploads/docs/The_Historical_Development_of_the_Indi an_Act_Aug_1978.pdf

Indian Affairs and Northern Development. (1997). Gathering strength: Canada's Aboriginal action plan. Ottawa, ON: Aboriginal Affairs and Northern Development. Retrieved from http://www.ahf.ca/downloads/gathering-strength.pdf

Indian Chiefs of Alberta. (2011). Citizens plus. Aboriginal Policy Studies, 1(2), 188-281. doi: 10.5663/aps.v1i2.11690

Indian Tribes of Manitoba. (1971). Wahbung: Our Tomorrows. Winnipeg, MB: Manitoba Indian Brotherhood Inc.

Indigenous and Northern Affairs Canada. (2010). Mining and mineral reports - Canada. Ottawa, ON: Indigenous and Northern Affairs Canada. Retrieved from https://www.aadncaandc.gc.ca/eng/1100100034846/1100100034847

Indigenous and Northern Affairs Canada. (2015). Comprehensive Claims. Ottawa, ON: Indigenous and Northern Affairs Canada. Retrieved from https://www.aadncaandc.gc.ca/eng/1100100030577/1100100030578

Indigenous and Northern Affairs Canada. (2016a). Leadership selection in First Nations. Ottawa, ON: Indigenous and Northern Affairs Canada. Retrieved from https://www.aadncaandc.gc.ca/eng/1323195944486/1323196005595

Indigenous and Northern Affairs Canada. (2016b). General briefing note on Canada's selfgovernment and comprehensive land claims policies and the status of negotiations. Ottawa, ON: Indigenous and Northern Affairs Canada. Retrieved from https://www.aadnc-aandc.gc.ca/eng/1373385502190/1373385561540\#s1 
Indigenous and Northern Affairs Canada. (2017a). Cumberland House Cree Nation profile.

Ottawa, ON: Indigenous and Northern Affairs Canada. Retrieved from http://fnpppn.aandc-

aadnc.gc.ca/fnp/Main/Search/FNRegPopulation.aspx?BAND_NUMBER=350\&lang=eng

Indigenous and Northern Affairs Canada. (2017b). List of Acts. Ottawa, ON: Indigenous and

Northern Affairs Canada. Retrieved from http://www.aadnc-

aandc.gc.ca/eng/1100100032317/1100100032318

Indigenous and Northern Affairs Canada. (2017c). Governance: Cumberland House Cree

Nation. Ottawa, ON: Indigenous and Northern Affairs Canada. Retrieved from http://fnpppn.aandc-

aadnc.gc.ca/fnp/Main/Search/FNGovernance.aspx?BAND_NUMBER=350\&lang=eng

Indigenous and Northern Affairs Canada. (2017d). Registered Population: Opaskwayak Cree

Nation. Ottawa, ON: Indigenous and Northern Affairs Canada. Retrieved from http://fnpppn.aandc-

aadnc.gc.ca/fnp/Main/Search/FNRegPopulation.aspx?BAND_NUMBER=315\&lang=eng

Indigenous and Northern Affairs Canada. (2017e). National Summary on Specific Claims.

Ottawa, ON: Indigenous and Northern Affairs Canada. Retrieved from

http://services.aadnc-

aandc.gc.ca/SCBRI_E/Main/ReportingCentre/External/externalreporting.aspx

Innes, R. A. (2013). Elder brother and the law of the people: Contemporary kinship and Cowessess First Nation. Winnipeg, MB: University of Manitoba Press. 
Institute on Governance. (2015). Revisiting RCAP towards reconciliation: The future of Indigenous governance. Conference Report. Ottawa, ON: Institute on Governance. Retrieved from https://iog.ca/docs/Revisiting-RCAP-Conference-Report.pdf International Covenant on Civil and Political Rights. (1966). UN General Assembly. United Nations, Treaty Series, vol. 999, p. 171 Retrieved from http://www.refworld.org/docid/3ae6b3aa0.html [accessed 5 November 2017]

Inwood, G. J. (2012). Understanding Canadian public administration: An introduction to theory and practice. Toronto, ON: Pearson Prentice Hall.

Irlbacher-Fox, S. (2009). Finding Dahshaa: Self-government, social suffering and, Aboriginal policy in Canada. Vancouver, BC: UBC Press.

Irlbacher-Fox, S. (2014). Traditional knowledge, co-existence and co-resistance. Decolonization: Indigeneity, Education \& Society, 3(3), 145-158.

Isaac, T. (1992). The 1992 Charlottetown accord and First Nations peoples: Guiding the future. Native Studies Review, 8(2), 109-114. Retrieved from http://iportal.usask.ca/docs/Native_studies_review/v8/issue2/pp109-114.pdf

Isaac, T. (1993). Balancing rights: The Supreme Court of Canada, R. v. Sparrow, and the future of Aboriginal rights. Canadian Journal of Native Studies, 13(2), 199-219. Retrieved from http://www3.brandonu.ca/library/CJNS/13.2/

Isaac, T. (2012). Aboriginal law: Commentary and analysis. Saskatoon, SK: Purich Publishing. Isaac, T., \& Annis, K. (2010). Treaty rights in the historic treaties of Canada. Saskatoon, SK: Native Law Centre University of Saskatchewan.

Iseke-Barnes, J. M. (2008). Pedagogies for decolonizing. Canadian Journal of Native Education, 31(1), 123-148. Retrieved from 
http://search.proquest.com.ezproxy.lib.ryerson.ca/docview/230303573?pq-

origsite $=$ summon

Isett, K. R., Mergel, I. A, LeRoux, A., Mischen, P. A., \& Rethemeyer, R. K. (2011). Networks in public administration scholarship: Understanding where we are and where we need to go. Journal of Public Administration Research and Theory, 21, i157-i173. doi:10.1093/jopart/muq061

Jacobs, R. (1991). Iroquois great law of peace and the United States constitution: How the founding fathers ignored the clan mothers. American Indian Law Review, 16(2), 497-531. Retrieved from http://www.jstor.org/stable/20068706

Jaine, L. \& Halfe, L. (1989). Traditional Cree Philosophy: Death, Bereavement and Healing. Saskatchewan Indian. Retrieved from http://www.sicc.sk.ca/archive/saskindian/a89mar11.htm

Jetté, D. A. (2002). On the outside looking in: Opening the door to indigenous knowledge contributions to Aboriginal governance in Canada (Master's Thesis). Retrieved from ProQuest.

Jobin, S. (2005). Guiding philosophy and governance model of Bent Arrow traditional healing society (Master's Thesis). University of Victoria.

Jobin. S. (2014). Cree economic relationships, governance, and critical Indigenous political economy in resistance to settler-colonial logics (Doctoral Dissertation). University of Alberta.

Jobs and Growth Act. (2012). S.C. 2012, c. 31. Retrieved from http://lawslois.justice.gc.ca/eng/AnnualStatutes/2012_31/page-1.html 
Johansen, B. (2009). Native American governance and the United States constitution. eJournal USA, 14(6), 12-16. Retrieved from http://iipdigital.usembassy.gov/media/pdf/ejs/0609.pdf

Johnson, I. (1984). Helping Indians to Help Themselves - A Committee to Investigate Itself, The 1951 Indian Act Consultation Process. Ottawa: Treaties and Historical Research Centre, DIAND.

Johnson, T.R. (1996). Roots of contemporary Native American activism. American Indian Culture and Research Journal, 20(2), 127-154. doi: https://doi.org/10.17953/aicr.20.2.ax43x4x379305468

Jones, M. D., \& McBeth, M. K. (2010). A narrative policy framework: Clear enough to be wrong? Policy Studies Journal, 38(2), 329-253.

Jorgensen, M. \& Taylor, J. B. (2000). What determines economic success? Evidence from tribal and individual Indian enterprises. Cambridge, MA: Malcolm Weiner Centre for Social Policy. Retrieved from http://hpaied.org/images/resources/publibrary/PRS00-3.pdf

Kahler, M. (2009). Networked politics: Agency, power and governance. In M. Kahler (Ed.), Networked politics: Agency, power and governance (1-20). Ithaca, NY: Cornell University Press.

Kappo, T. (2016). Mîkistahikâcimo (to tell a story through beadwork): Revitalizing Indigenous governance practices through beaded narratives beadwork. Presentation, Native American and Indigenous Studies Association, Honolulu, Hawaii.Kavanagh, S. (2016, October 20) Sobeys closing IGA st Sobeys closing IGA store in OCN, blames 'current economic situation'ore in OCN, blames 'current economic situation'. CBC News. 
Retrieved from http://www.cbc.ca/news/canada/manitoba/iga-sobeys-the-pas-closes1.3813670

Keal, P. (2007). Indigenous self-determination and the legitimacy of sovereign states. International Politics, 44(2-3), 287-305. doi: 10.1057/palgrave.ip.8800189

Keith, J. (2013). The TłlCho agreement and small acts of freedom: From self-government to selfdetermination (Master's Thesis). Retrieved from Proquest.

Kernaghan, K., \& Siegel, D. (1999). Public administration in Canada. Toronto, ON: ITP Nelson.

Kolb, D. A. (1984). Experiential learning: Experience as the source of learning and development. Englewood Cliffs, NJ: Prentice Hall.

Kovach, M. (2009). Indigenous methodologies: Characteristics, conversations and contexts. Toronto, On: University of Toronto Press.

Kulchyski, P. (1993). Anthropology in the service of the state: Diamond Jenness and Canadian Indian policy. Journal of Canadian Studies, 28(2), 21-50.

Kulchyski, P. (2005). Like the sound of a drum: Aboriginal cultural politics in Denedeh and Nunavut. Winnipeg, MB: University of Manitoba Press.

Kuokkanen, R. (2012). Self-determination and Indigenous women's rights at the intersection of international human rights. Human Rights Quarterly, 34(1), 225-250.

Kundook, J. G. (2014). Transforming our Nuuyum: Contemporary Indigenous leadership and governance. Indigenous Law Journal, 12(1), 33-60.

LaBoucane-Benson, P., Gibson, G., Benson, A., \& Miller, G. (2012). Are we seeking Pimatisiwin or creating Pomewin? Implications for water policy. International Indigenous Policy Journal, 3(3), DOI: 10.18584/iipj.2012.3.3.10 
Ladner, K. L. (2000). Women and Blackfoot nationalism. Journal of Canadian Studies/Revue d'Études Canadiennes, 35(2), 35-62. Retrieved from http://search.proquest.com.ezproxy.lib.ryerson.ca/docview/1300026222/fulltextPDF?acco untid $=13631$

Ladner, K. (2001a). Negotiated inferiority: The royal commission on Aboriginal people's vision of a renewed relationship. American Review of Canadian Studies, 31(1), 241-264. doi:10.1080/02722010109481593

Ladner, K. (2001b). When buffalo speaks: Creating an alternative understanding of traditional Blackfoot governance (Doctoral Dissertation). Retrieved from ProQuest.

Ladner, K. (2003). Governing within an ecological context: Creating an AlterNative understanding of Blackfoot governance. Studies in Political Economy, 61(70), Spring, $125-152$

Ladner, K. L. (2005). Up the creek: Fishing for a new constitutional order. Canadian Journal of Political Science/Revue Canadienne de science politique, 38(4), 923-953.

Ladner, K. (2006). Indigenous governance: Questioning the status and the possibilities for reconciliation with Canada's commitment to Aboriginal and treaty rights (Research Paper). Vancouver, BC: National Centre for First Nations Governance. Retrieved from http://fngovernance.org/ncfng_research/kiera_ladner.pdf

Ladner, K. (2009). Take 35: Reconciling constitutional orders. In A.M. Timpson (Ed.), First Nations, first thoughts: The impact of Indigenous thought in Canada (pp. 279-300). Vancouver, BC: UBC Press. 
Ladner, K. (2014). Political genocide: Killing nations through legislation and slow moving poisons. In A. Woolford, J. Benvenuto \& A. Hinton (Eds.), Colonial genocide and Indigenous North America (pp. 226-245). Durham NC: Duke University Press.

Ladner, K. L (2017) 150 Years and waiting: Will Canada become and honourable nation? In K. Ladner \& M. K. Tait (Eds.), Surviving Canada: Indigenous Peoples Celebrate 150 Years of Betrayal (pp.398-413). Winnipeg, MB: ARP Books.

Laenui, P. (2000). Processes of decolonization. In M. Battiste (Ed.), Reclaiming Indigenous voice and vision (pp. 150-160). Vancouver, BC: UBC Press.

Lavallée, L. F. (2007). Physical activity and healing through the medicine wheel. Pimatisiwin: A Journal of Aboriginal and Indigenous Health, 5(1), 127-153.

Lavallée, L. F. (2008). Balancing the medicine wheel through physical activity. Journal of Aboriginal Health, 4(1), 64-71.

Lavallée, L. F. (2009). Practical application of an Indigenous research framework and two qualitative Indigenous research methods: Sharing circles and Anishnaabe symbol-based reflection. International Journal of Qualitative Methods, 8(1), 21-40.

Lavallée, L. F. \& Howard, H. A. (2011). Urban aboriginal diabetes research project report. Toronto, ON: Anishnawbe Health Toronto.

Lawrence, B. (2004). 'Real'Indians and others: Mixed-blood urban native peoples and Indigenous nationhood. Lincoln, NB: University of Nebraska Press.

Lee, D. (2015). Adoption is (not) a dirty word: Towards an adoption-centric theory of Anishinaabeg citizenship. First Peoples Child \& Family Review: An Interdisciplinary Journal, 10(1), 86-98. 
Légaré, A. (2010). The construction of Nunavut: The impact of the Nunavut project on Inuit identity, governance and society (Doctoral Dissertation). Retrieved from ProQuest.

Legislative Assembly of Saskatchewan. (2000). Saskatchewan hansard. Regina, SK:

Government of Saskatchewan. Retrieved from

http://docs.legassembly.sk.ca/legdocs/Legislative\%20Assembly/Hansard/24L1S/000607

\section{H.PDF}

Leslie, J. F. (2002). The Indian act: An historical perspective. Canadian Parliamentary Review, 25(2), 23-27.

Leslie, J. F. (2004). The policy agenda of native peoples from World War II to the 1969 white paper. In J. P. White, P. Maxim \& D. Beavon (Eds.), Aboriginal Policy Research: Setting the Agenda for Change Volume 1. Retrieved from http://apr.thompsonbooks.com/vols/APR_Vol_1Ch1.pdf

Lightfoot, S. (2016). Global Indigenous politics: A subtle revolution. London, UK: Routledge.

Lincoln, Y. S., \& Guba, E. G. (2011). Paradigmatic controversies, contradictions, and emerging confluences. In N. K. Denzin \& Y. S. Lincoln (Eds.), Handbook of qualitative research ( $4^{\text {th }}$ Ed., pp. 97-128). Thousand Oaks, CA: Sage.

Little Bear, L., Boldt, M. \& Long, J. A. (1984). Pathways to self-determination: Canadian Indians and the Canadian state. Toronto, ON: University of Toronto Press.

Loukacheva, N. (2009). Nunavut and Canadian Arctic sovereignty. Journal of Canadian Studies, $43(2), 82-108$

Maaka, R., \& Fleras, A. (2008). Contesting Indigenous peoples governance: The politics of statedetermination vs. self-determining autonomy. In Y.D. Belanger (Ed.), Aboriginal Self- 
Government in Canada: Current Trends and Issues (3rd ed., pp. 69-101). Saskatoon, SK: Purich Publishing.

Maaka, R., \& Fleras, A. (2009). Mainstreaming indigeneity by indigenizing policymaking: towards an Indigenous grounded analysis framework as policy paradigm. Indigenous Policy Journal, 20(3), 1-21.

Macklem, P. (2001). Indigenous Difference and the Constitution of Canada. Toronto, ON: University of Toronto Press.

Mailhot, P.R. \& Sprague, D.N. (1985). Persistent settlers: The dispersal and resettlement of the Red River Métis, 1870-85. Canadian Ethnic Studies, 17(2), 1-30.

Makokis, L. J. (2001). Teachings from Cree Elders: A grounded theory study of Indigenous leadership (Doctoral Dissertation). Retrieved from ProQuest.

Malcolmson, P., Meyers, R., Baier, G., and Bateman, T. M. J. (2016). The Canadian Regime: An Introduction to Parliamentary Government in Canada (6th ed). Toronto, ON: University of Toronto Press,

Mandelbaum, D. G. (1979). The Plains Cree: An ethnographic, historical, and comparative study. Regina, SK: University of Regina.

Mann, C. C. (2006). 1491: New revelations of the Americas before Columbus. New York, NY: Vintage Books.

Mann, C.C. (2011). 1493: Uncovering the new world Columbus created. New York, NY: Vintage Books.

Manuel, A., \& Derrickson, G.C.R.M. (2015). Unsettling Canada: A national wake-up call. Toronto, ON: Between the Lines. 
Manuel, G., \& Posluns, M. (1974). The fourth world: An Indian reality. Don Mills, ON: CollierMacMillan Canada Ltd.

Marchildon, G., \& Robinson, S. (2015). Canoeing the Churchill: A practical guide to the historic voyageur highway. Regina, SK: University of Regina Press.

Martin, D. \& Adams, C. (2000). Canadian public opinion regarding Aboriginal self- government: Diverging viewpoints as found in national survey results. American Review of Canadian Studies, 30(1), 79-88. doi: 10.1080/02722010009481794

Marule, M. S. (1984). Traditional Indian government: Of the people, by the people, for the people. In Littlebear, L., Boldt, J., \& Long, A. (Eds.), Pathways to self-determination: Canadian Indians and the Canadian state (pp. 36-45). Toronto, ON: University of Toronto.

Mason, M. (2010). Sample size and saturation in PhD studies using qualitative interviews. Forum Qualitative Sozialforschung / Forum: Qualitative Social Research, 11(3), 1-19. Retrieved from http://nbn-resolving.de/urn:nbn:de:0114-fqs100387.

McAdam, S. (2015). Nationhood interrupted: Revitalizing Nehiyaw legal systems. Saskatoon, SK: Purich Publishing.

McCallum, M. J. L. \& Klassen, S. (2017). Because it's 1951: The non-history of First Nations Female band suffrage and leadership. In K. Ladner \& M. K. Tait (Eds.), Surviving Canada: Indigenous Peoples Celebrate 150 Years of Betrayal (pp.215-235). Winnipeg, MB: ARP Books.

McGregor, D. (2010). Traditional knowledge, sustainable forest management, and ethical research involving Aboriginal peoples: An Aboriginal scholar's perspective. In J. P. White, J. Peters, D. Beavon, \& P. Dinsdale (Eds.), Aboriginal policy research: Voting, 
governance, and research methodology (pp. 227-244). Toronto, ON: Thompson Educational Publishing. Retrieved from http://apr.thompsonbooks.com/vols/APR_Vol_10Ch10.pdf

McGregor, D. (2014). Lessons for collaboration involving traditional knowledge and environmental governance in Ontario, Canada. AlterNative: An International Journal of Indigenous Peoples, 10(4), 340-353.

McLeod, N. (2005). Exploring Cree narrative memory (Doctoral Dissertation). Retrieved from ProQuest.

McLeod, N. (2007). Cree narrative memory: From treaties to contemporary Times. Saskatoon, SK: Purich Publishing Limited.

McLeod, N. (2016). 100 days of Cree. Regina, SK: University of Regina Press.

McNaughton, C., \& Rock, D. (2004). Opportunities in Aboriginal research: Results of SSHRC's dialogue on research and Aboriginal peoples. Native Studies Review, 15(2), 37-60.

McNeil, K. (1997). The meaning of Aboriginal title. In M. Asch (Ed.), Aboriginal and treaty rights in Canada: Essays on law, equality, and respect for difference (pp. 135-154). Vancouver, BC: UBC Press.

McNeil, K. (2004). The inherent right of self-government: Emerging directions for legal research. Chilliwack, BC: First Nations Governance Centre. Retrieved from https://portal.publicpolicy.utoronto.ca/en/ContentMap/AboriginalAffairsCanada/Aborigin al\%20Policy\%20and\%20Governance\%20Documents/Inherent\%20Right $\% 20$ to\%20Self\% 20Government\%20-\%20Emerging\%20Directions\%20for\%20Legal\%20Research,\%20Mc Neil,\%202004.pdf 
McNeil, K. (2005). Aboriginal rights, resource development, and the source of the Provincial duty to consult in Haida nation and Taku River. Supreme Court Law Review, 29, 447-460.

McNeil, K. (2007). The jurisdiction of inherent right Aboriginal governments. Vancouver, BC: National Centre for First Nations Governance. Retrieved from http://fngovernance.org/ncfng_research/kent_mcneil.pdf

Memmi, A. (1967). The Colonizer and the Colonized. Boston: Beacon Press.

Mercredi, O., \& Turpel, M. E. (1993). In the rapids: Navigating the future of first nations. Toronto, ON: Penguin Books.

Meyer, D., Gibson, T., \& Russell, R. (1992). The quest for Pasquatinow: An Aboriginal gathering centre in the Saskatchewan river valley. Prairie Forum, 38, 183-205.

Michell, H. (2012). School science from the eyes of the Woodlands Cree: Using the Migawap dwelling and traditional values as a guide to plot fundamental key concepts and ideas. Canadian Journal of Native Studies, 32(2), 19-49.

Mikisew Cree First Nation v. Canada (Minister of Canadian Heritage). (2005). 3 S.C.R. 388, 2005 SCC 69. Retrieved from https://scc-csc.lexum.com/scc-csc/scccsc/en/item/2251/index.do

Miller, J. R. (1989). Skyscrapers hide the heavens: A history of Indian-White relations in Canada. Toronto, ON: University of Toronto Press.

Miller, J. R. (2004). Lethal legacy: Current native controversies in Canada. Toronto, ON: McClelland \& Stewart Ltd.

Miller, J. R. (2009). Compact, contract, covenant: Aboriginal treaty-Making in Canada (Kindle Edition). Toronto, ON: University of Toronto Press. 
Miller, P. (2008). Validity. In The SAGE encyclopedia of qualitative research methods. (Vol. 2, pp. 909-910). Los Angeles, CA: SAGE Publications.

Milloy, J. S. (2001). A national crime: The Canadian government and the residential school system, 1879 to 1986 (3 ${ }^{\text {rd }}$ Ed.). Winnipeg, MB: University of Manitoba Press.

Milloy, J. S. (2008). Indian act colonialism: A century of dishonour, 1869-1969. Vancouver, BC: National Centre on First Nations Governance. Retrieved from http://fngovernance.org/ncfng_research/milloy.pdf

Minister of Justice. (2015). Indian Act. R.S.C., 1985, c. I-5. Ottawa, ON: Department of Justice. Retrieved from http://laws-lois.justice.gc.ca/PDF/I-5.pdf

Minkler, M. (2005). Community-based research partnerships: Challenges and opportunities. Journal of Urban Health, 82(S2), ii3-ii12. doi:10.1093/jurban/jti034

Minnesota Humanities Center. (2009). Ojibwe vocabulary project. St. Paul, MN: Minnesota Humanities Center. Retrieved from http://minnesotahumanities.org/resources/Book\%20Contents.pdf

Mitchell, L., \& Bruhn, J. (2009). Best practices for governance and administration of Aboriginal service delivery organizations. Ottawa, ON: Institute on Governance.

Miyo Wahkohtowin Education Authority. (2017). Online Cree Dictionary. Maskwacis, AB: Miyo Wahkohtowin Education Authority. Retrieved from http://www.creedictionary.com/

Mochoruk, J. (2007). Manitoba and the road to the natural resources transfer agreement. Review of Constitutional Studies, 12(2), 255-300.

Monture-Angus, P. (1999). Journeying forward: Dreaming First Nations' independence. Halifax, NS: Fernwood Publishing. 
Morellatto, M. (2008). The crown's constitutional duty to consult and accommodate Aboriginal and treaty rights(Research Paper). Vancouver, BC: National Centre for First Nations Governance. Retrieved from http://fngovernance.org/resources_docs/Crown_Duty_to_Consult_Accommodate.pdf

Morgan, D. L. (2008). Emergent design. In L. M. Given (Ed.) The SAGE encyclopedia of qualitative research methods (pp.246-249). Thousand Oaks, CA: SAGE Publications Ltd doi: $10.4135 / 9781412963909$

Morrison, A. N. (2012). Opaskwayak Cree nation wetland ethnoecology: Land, identity and wellbeing in a flooded landscape. (Master's Thesis).

Morse, B. W. (2008). Regaining recognition of the inherent right of Aboriginal governance. In Y.D. Belanger (Ed.) Aboriginal self-government in Canada: Current trends and issues (3rd ed., pp. 39-68). Saskatoon, SK: Purich Publishing.

Murphy, M. (2009). Civilization, self-determination and reconciliation. In A.M. Timpson (Ed.), First Nations, first thoughts: The impact of Indigenous thought in Canada (pp. 251-278). Vancouver, BC: UBC Press.

Napoleon, V. (2007). Thinking about Indigenous legal orders. Vancouver, BC: National Centre for First Nation Governance. Retrieved from http://fngovernance.org/ncfng_research/val_napoleon.pdf

Napoleon, V. (2009). Aboriginal discourse: Gender, identity, and community. In B. J. Richardson, S. Imai, \& K. McNeil (Eds.), Indigenous peoples and the law: Comparative and critical perspectives (pp. 233-255). Oxford, UK: Hart Publishing. 
National Centre for First Nations Governance. (2008). Governance best practices report.

Vancouver, BC: National Centre for First Nation Governance. Retrieved from http://fngovernance.org/publication_docs/NCFNG_Best_Practice_Report.pdf

National Indian Brotherhood. (1972). Indian Control of Indian Education: Policy Paper. Ottawa, ON: National Indian Brotherhood.

Neu, D. \& Therrien, R. (2003). Accounting for genocide: Canada's bureaucratic assault on Aboriginal people. Black Point, NS: Fernwood Publishing.

Nichols, R. L. (2005). Realizing the social contract: The case of colonialism and indigenous peoples. Contemporary Political Theory, 4(1), 42-62. doi: 10.1057/palgrave.cpt.9300153

Nickel, S. (2014). 'You'll probably tell me that your grandmother was an Indian princess': Identity, community, and politics in the oral history of the union of British Columbia Indian chiefs. 1969-1980." Oral History Forum 34, 1-19.

Nicol, H. N. (2010). Reframing sovereignty: Indigenous peoples and Arctic states. Political Geography, 29(2), 78-80. doi: 10.1016/j.polgeo.2010.02.010

Niezen, R. (1993). Telling a message: Cree perceptions of custom and administration. Canadian Journal of Native Studies, 13(2), 221-250. Retrieved from http://www3.brandonu.ca/library/CJNS/13.2/niezen.pdf

Obomsawin, A. (1993). Kanehsatake: 270 years of resistance. Toronto, ON: National Film Board of Canada. Retrieved from https://www.nfb.ca/film/kanehsatake_270_years_of_resistance

Okimasis, J. L. (2004). Cree: Language of the plains. Nehiyawewin: Paskwawi-Pikiskwewin. Regina, SK: University of Regina. 
Olesen, V. (2011). Feminist qualitative research in the millenium's first decade: Developments, challenges, prospects. In N. K. Denzin \& Y. S. Lincoln (Eds.), Handbook of qualitative research (4 ${ }^{\text {th }}$ Ed., pp. 129-146). Thousand Oaks, CA: Sage Publications.

Opaskwayak Cree Nation. (2016a). Election code. The Pas, MB: Opaskwayak Cree Nation. Retrieved from http://opaskwayakcreenation.ca/uploads/3/4/9/3/34931393/election_code_final_march_3 2016.pdf

Opaskwayak Cree Nation. (2016b). History of Opaskwayak Cree Nation. The Pas, MB: Opaskwayak Cree Nation. Retrieved from http://www.opaskwayak.ca/history.php

Opekokew, D. (1980). The First Nations: Indian government and the Canadian confederation. Saskatoon, SK: Federation of Saskatchewan Indians.

O,Reilly-Scanlon, K., Crowe, C., \& Weenie, A. (2004). Pathways to understanding: "Wahkohtowin" as a research methodology. McGill Journal of Education, 39(1), 29-44. Retrieved from Scholars Portal Journals.

Orsini, M., \& Smith, M. (2007). Critical policy studies. In M. Orsini \& M. Smith (Eds.), Critical Policy Studies (pp. 1-18). Vancouver, BC: UBC Press.

Overeem, P. (2008). Beyond heterodoxy: Dwight Waldo and the politics-administration dichotomy. Public Administration Review, 68(1), 36-45.

Pal, L. A. (2010). Beyond policy analysis: Public issue management in turbulent times. Ottawa, ON: Carleton University.

Palmater, P. (2000). An empty shell of a treaty promise: R v Marshall and the rights of non-status Indians. Dalhousie Law Journal, 23(1), 102-148. Retrieved from HeinOnline. 
Palmater, P. (2011a). Beyond blood: Rethinking Indigenous identity. Saskatoon, SK: Purich Publishing.

Palmater, P. (2011b). Stretched beyond human limits: Death by poverty in First Nations. Canadian Review of Social Policy, 65/66, 112-127.

Palmater, P. D. (2013). Matnm tel-mi'kmawi: I'm fighting for my mi'kmaw identity. Canadian Journal of Native Studies, 33(1), 147-167.

Palmater, P. (2015). Indigenous nationhood: Empowering grassroots citizens. Halifax, NS: Fernwood Publishing.

Palmater, P. (2016). My tribe, my heirs and their heirs forever: Living Mi'kmaw treaties. In M. Battiste (Ed.), Living treaties: Narrating Mi’kmaw treaty relations, (pp. 24-41). Sydney, NS: Cape Breton University Press.

Papillon, M. (2012). Adapting Federalism: Indigenous multilevel governance in Canada and the United States. Publius: The Journal of Federalism, 42(2), 289-312. doi:10.1093/publius/pjr032

Pasternak, S. (2014). Jurisdiction and settler colonialism: Where do laws meet? Canadian Journal of Law and Society, 29(2), 145-161. doi:10.1017/cls.2014.5

Patterson, L. L. (2006). Aboriginal roundtable to Kelowna accord: Aboriginal policy negotiations 2004-2005. Ottawa, ON: Political and Social Affairs Division. Retrieved from http://www.parl.gc.ca/Content/LOP/researchpublications/prb0604-e.pdf

Paul, D. N. (2006). First Nations history: We were not the savages: Collision between European and Native American civilizations. ( $3^{\text {rd }}$ Ed.). Halifax, NS: Fernwood Publishing.

Paupanekis, K. (2008). Pocket Cree: A phrasebook for nearly all occasions. Winnipeg. MB: Mazinaate Inc. 
Peach, I. L. (2009). Reconciling the constitutional order: Positing a new approach to the development of Indigenous self-government and Indigenous law (Master's Thesis). Kingston, ON: Queen's University.

Peach, I. (2011). The power of a single feather: Meech lake, Indigenous resistance and the evolution of Indigenous politics in Canada. Review of Constitutional Studies, 16(1), 1-29. Retrieved from http://go.galegroup.com.ezproxy.lib.ryerson.ca/ps/i.do?p=AONE\&u=rpu_main\&id=GAL E\%7CA307414183\&v=2.1\&it=r\&sid=summon\&userGroup=rpu_main\&authCount=1

Peel, A. (2011). Exciting prejudice and privilege and listening to the "other": The case for Indigenizing public governance in Canada (Master Thesis). Retrieved from ProQuest Dissertations \& Theses.

Peters, G., Pierre, J., \& Stoker, G. (2010). The relevance of political science. In D. Marsh \& G. Stoker (Eds.), Theory and methods in political science (3rd ed., pp. 325-342). Basingstoke, UK: Palgrave Macmillan.

Pitty, R., \& Smith, S. (2011). The Indigenous challenge to Westphalian sovereignty. Australian Journal of Political Science, 46(1), 121-139. doi: 10.1080/10361146.2010.546336

Poelzer, G., \& Coates, K. S. (2016). From treaty peoples to treaty nation: A road map for all Canadians. Vancouver. BC: UBC Press.

Porter, R. O. (2005). The decolonization of Indigenous governance. In W. A. Wilson \& M. Y. Bird (Eds.), For Indigenous eyes only: A decolonization handbook (pp.87-108). Santa Fe, NM: School of American Research Press.

Pratt, A. (2004). Treaties vs. Terra Nullius: "Reconciliation,” treaty-making and Indigenous sovereignty in Australia and Canada. Indigenous Law Journal, 3, 43-60. 
Pratt, D., Bone, H., \& The Treaty and Dakota Elders of Manitoba. (2014). Untuwe Pi Kin HeWho we are: Treaty elders'teachings Volume 1. Winnipeg, MB: Treaty Relations Commission of Manitoba.

Preston, J. (2013). Neoliberal settler colonialism, Canada and the tar sands. Race \& Class, 55(2), 42-59.

Price, J. (2008). Living Inuit governance in Nunavut. In L. Simpson (Ed.), Lighting the eighth fire: The liberation, resurgence, and protection of Indigenous nations (pp. 127-138). Winnipeg, MB: Arbeiter Ring Publishing.

Provart, J. (2003). Reforming the Indian Act: First Nations governance and Aboriginal policy in Canada. Indigenous Law Journal, 2, 117-169.

QSR International. (2015). What is NVivo? Doncaster, Australia: QSR International. Retrieved from http://www.qsrinternational.com/what-is-nvivo

R. v. Pamajewon. (1996). 2 S.C.R. 821. Ottawa, ON: Department of Justice. Retrieved from http://scc.lexum.org/decisia-scc- csc/scc-csc/scc-csc/en/1411/1/document.doc

R. v. Sparrow. (1990). 1 S.C.R. 1075. Ottawa, ON: Department of Justice. Retrieved from http://scc.lexum.org/en/1990/1990scr1-1075/1990scr1-1075.pdf

R. v. Van der Peet. (1996). 2 S.C.R. 507. Ottawa, ON: Department of Justice. Retrieved from http://scc-csc.lexum.com/scc-csc/scc-csc/en/item/1407/index.do

Ratt, S. (2016). Maci-nehiyawewin: Beginning Cree. Regina, SK: University of Regina Press.

Ray, A. J. (1974). Indians in the fur trade: Their role as trappers, hunters, and middlemen in the lands southwest of Hudson Bay, 1660-1870. Toronto, ON: University of Toronto Press.

Regan, P. (2010). Unsettling the settler within: Indian residential schools, truth telling, and reconciliation in Canada. Vancouver, BC: UBC Press. 
Relland, M. R. (1998). The teachings of the Bear clan: As told by Saulteaux Elder Danny Musqua (Master's Thesis). Retrieved from https://ecommons.usask.ca/bitstream/handle/10388/etd-06292007140740/Relland_michael_1998.pdf

Rich, E. E. (1951). Cumberland House journals and inalnd journal 1775-82: First Series, 177579. London UK: The Hudson's Bay Record Society.

Richards, J. \& Krass, M. (2015). First Nations own-source revenue: How is the money spent? (Commentary No. 437). Toronto, ON: C.D. Howe Institute. Retrieved from https://www.cdhowe.org/sites/default/files/attachments/research_papers/mixed/Comment ary_437.pdf

Riley, A. R. (2007). Good (Native) Governance. Columbia Law Review, 107(5), 1049-1125. Retrieved from HeinOnline.

Ringley, L. I. (1999). Internationalization of an Indigenous anticolonial cultural critique of research methodologies: A guide to Indigenist research methodology and its principles. Wicazo Sa Review, 14(2), 109-121. Retrieved from JSTOR http://www.jstor.org/stable/1409555.

Robbins, J. (2010). A nation within? Indigenous peoples, representation and sovereignty in Australia. Ethnicities, 10(2), 257-274.

Roe, E. (1994). Narrative policy analysis: Theory and practice. Durham, CT: Duke University Press.

Rollo, T. (2014). Mandates of the state: Canadian sovereignty, democracy, and Indigenous claims. Canadian Journal of Law and Jurisprudence, 27(1), 225-238. 
Royal Commission on Aboriginal Peoples. (1996). Report of the Royal Commission on Aboriginal People. Ottawa, ON: Canada Communication Group. Retrieved from http://www.collectionscanada.gc.ca/webarchives/20071115053257/http://www.aincinac.gc.ca/ch/rcap/sg/sgmm_e.html

Royal Proclamation. (1763). The Royal Proclamation - October 7, 1763, by the King. A proclamation George R. Retrieved from http://avalon.law.yale.edu/18th_century/proc1763.asp

Rubin, H. J., \& Rubin, I. S. (2012). Qualitative interviewing: The art of hearing data ( $3^{\text {rd }}$ ed.). Thousand Oaks, CA: Sage Publications.

Russell, D. R. (1991). Eighteenth-Century Western Cree and their neighbours. Hull, QC: Canadian Museum of Civilization.

Russell, P. H. (2017). Canada's odyssey: A country based on incomplete conquests. Toronto: University of Toronto Press.

Rustand, J. K. (2010). Is “inherent Aboriginal self-government” constitutional? Calgary, AB: Canadian Constitutional Foundation. Retrieved from http://theccf.ca/wpcontent/uploads/2013/07/Is-Inherent-Aboriginal-Self-Government-Constitutional-12-0110.pdf

Ryerson University. (2017). Chair in Indigenous governance. Toronto, ON: Ryerson University. Retrieved from http://www.ryerson.ca/chair-indigenous-governance/about-thechair/about-the-chair-program/

Ryerson University Library and Archives. (2016). Informit Indigenous collection. Toronto, ON: Ryerson University. Retrieved from http://library.ryerson.ca/info/giving/informitindigenous-collection/ 
Rynard, P. (2000). Welcome in, but check your rights at the door": The James Bay and Nisga'a agreements in Canada. Canadian Journal of Political Science, 33(2), 211-243.

Sabatier, P. (2007). The need for better theories. In P. Sabatier (Ed.), Theories of the policy process (pp. 3-17). Cambridge, UK: Westview Press.

Saldaña, J. (2013). The coding manual for qualitative researchers ( $2^{\text {nd }}$ ed.). London, UK: Sage Publications.

Sanders, D. (1975). Indian women: A brief history of their roles and rights. McGill Law Journal, 21, 656-672. Retrieved from http://www.lawjournal.mcgill.ca/userfiles/other/869650sanders.pdf

Sanderson, D. (2014). Overlapping consensus, legislative reform and the Indian Act. Queen's Law Journal, 39(2), 511-550. Retrieved from http:/queensu.ca/lawjournal/issues/pastissues/Volume39-2/05-Sanderson.pdf

Saul, J. R. (2008). A fair country: Telling truths about Canada. Toronto, ON: Viking Group.

Scheurich, J. J., \& Young, M. D. (1997). Coloring epistemologies: Are our research epistemologies racially biased? Educational Researcher, 26(4), 4-16.

Schlager, E., \& Weible, C.M. (2013). New theories of the policy process. Policy Studies Journal, 41(3), 389-396. doi: 10.1111/psj.12030

Secretariat of the Convention on Biological Diversity. (2016). Traditional knowledge and the Convention on Biological Diversity. Montreal, QC: Secretariat of the Convention on Biological Diversity. Retrieved from https://www.cbd.int/traditional/intro.shtml

Seidman, I. (2013). Interviewing as qualitative research: A guide for researchers in education and the social sciences ( $4^{\text {th }}$ ed.). New York, NY: Teachers College Press. 
Settee, P. (2007). Pimatisiwin: Indigenous knowledge systems, our time has come. (Doctoral Dissertation). Saskatoon, SK: University of Saskatchewan.

Shadian, J. (2006). Reconceptualizing sovereignty through Indigenous autonomy: A case study of Arctic governance and the Inuit circumpolar conference. (Doctoral Dissertation). Newark, NJ: University of Delaware.

Shaw, R. (2013). 'Meaning just what I choose it to mean - neither more nor less': The search for governance in Political Science. Political Science, 65(2), 178-197. DOI: $10.1177 / 0032318713504084$

Simeone, T. \& Troniak, S. (2012). Bill S-6: An act respecting the election and term of office of chiefs and councillors of certain First Nations and the composition of council of those First Nations (Legislative Summary No. 41-1-S6-E). Ottawa, ON: Library of Parliament. Retrieved from http://www.lop.parl.gc.ca/Content/LOP/LegislativeSummaries/41/1/s6e.pdf

Simon, M. (2009). Inuit and the Canadian Arctic: Sovereignty begins at home. Journal of Canadian Studies, 43(2), 250-260.

Simpson, A. (2014). Mohawk interruptus: Political life across the borders of settlers states. Durham NC: Duke University Press.

Simpson, L. (1999). The construction of traditional ecological knowledge: Issues, implications, and insights (Doctoral Dissertation). Retrieved from Proquest.

Simpson, L. (2004). Anticolonial strategies for the recovery and maintenance of Indigenous knowledge. American Indian Quarterly, 28(3/4), 373-384.

Simpson, L. (2008a). Looking after Gdoo-naaganinaa: Precolonial Nishnaabeg diplomatic and treaty relationships. Wicazo Sa Review, 23(2), 29-42. 
Simpson, L. (2008b). Our elder brothers: The lifeblood of resurgence. In L. Simpson (Ed.), Lighting the eighth fire: The liberation, resurgence, and protection of Indigenous nations (pp. 73-88). Winnipeg, MB: Arbeiter Ring Publishing.

Simpson, L. (2008c). Oshkimaadiziig, the new people. In L. Simpson (Ed.), Lighting the eighth fire: The liberation, resurgence, and protection of Indigenous nations (pp.13-23). Winnipeg, MB: Arbeiter Ring Publishing.

Simpson, L. (2011). Dancing on our turtle's back: Stories of Nishnaabeg re-creation, resurgence and a new emergence. Winnipeg, MB: Arbeiter Ring Publishing.

Sinclair, R. (2007). All my relations - Native transracial adoption: A critical case study of cultural identity (Doctoral Dissertation). Retrieved from ProQuest Dissertations and Theses.

Smith, J. G. E. (1981). Western Woods Cree. In W. C. Sturtevant (Ed.), Handbook of North American Indians (pp. 256-270). Washington, DC: Smithsonian Institution.

Smith, G. H. (2000). Protecting and respecting Indigenous knowledge. In M. Battiste (Ed.), Reclaiming Indigenous Voice and Vision (pp. 209-224). Vancouver, BC: UBC Press.

Smith, L. T. (2012). Decolonizing methodologies: Research and Indigenous peoples. London, UK: Zed Books.

Snyder, E. (2013). Gender and Indigenous law. Victoria, BC: University of Victoria Indigenous Law Unit. Retrieved from http://indigenousbar.ca/indigenouslaw/wpcontent/uploads/2013/04/Gender-and-Indigenous-Law-report-March-31-2013ESnyder1.pdf

Snyder, E. (2016). Absences and erasures: Gender, power, and Cree law (Lecture). Indigenous, Social, and Legal Perspectives on Miyo Pimachihowin. 
Statistics Canada. (2016). Census Profile, 2016 Census: Cumberland House, Northern Village.

Ottawa, ON: Statistics Canada. Retrieved from http://www12.statcan.gc.ca/censusrecensement/2016/dp-

$\mathrm{pd} /$ prof $/$ details/page.cfm?Lang $=\mathrm{E} \&$ Geo $1=\mathrm{CSD} \&$ Code $1=4718005 \& \mathrm{Geo} 2=\mathrm{CD} \& \mathrm{Code} 2=4$ 718\&Data $=$ Count $\&$ SearchText $=$ cumberland $\% 20$ house $\&$ SearchType $=$ Begins $\&$ SearchPR $=$ $01 \& \mathrm{~B} 1=\mathrm{A} 11 \& \mathrm{TABID}=1$

St. Catharines Milling and Lumber Co. v. R. (1887). 13 S.C.R. 577. Ottawa, ON: Department of Justice. Retrieved from https://scc-csc.lexum.com/scc-csc/scc-csc/en/item/3769/index.do St. Denis, V. (2007). Feminism is for everybody: Aboriginal women, feminism and diversity. In J. Green (Ed.), Making space for Indigenous feminism (pp. 33-50). Black Point, N.S.: Fernwood Pub.

Steinhauer-Hill, P. J. (2008) Kihkipiw: A Cree way. (Doctoral Dissertation). Edmonton, AB: University of Alberta. Retrieved from Proquest.

Stevenson, W. (2000). Decolonizing tribal histories (Doctoral Dissertation). Retrieved from ProQuest.

Stiegelbauer, S. M. (1996). What is an Elder? What do Elders do?: First Nation Elders as teachers in culture-based urban organizations. Canadian Journal of Native Studies, 16(1), $37-66$.

Stoker, G. (1998). Governance as theory: Five propositions. International Social Science Journal, 50(155), 17-28. Retrieved from http://journals2.scholarsportal.info.ezproxy.lib.ryerson.ca/pdf/00208701/v50i0155/ 17_gatfp.xml 
Stone, D. (2008). Global public policy, transnational policy communities and their networks. The Policy Studies Journal, 36(1), 19-38. doi: 10.1111/j.1541-0072.2007.00251.x

Stonechild, B. (2002). The iron alliance and domination of the Northern Plains, 1690 to 1885 : Implications for the concept of Iskunican. (Unpublished Research Paper).

Stonechild, B. (2006). The new buffalo: The struggle for Aboriginal post-secondary education in Canada. Winnipeg, MB: University of Manitoba Press.

Stonechild, B. (2016). The knowledge seeker: Embracing Indigenous spirituality. Regina, SK: University of Regina Press.

Svara, J. H. (2008). Beyond dichotomy: Dwight Waldo and the intertwined politicsadministration relationship. Public Administration Review, 68(1), 46-52. doi: 10.1111/j.1540-6210.2007.00834.x

Swain, H. (2010). Oka: A political crisis and its legacy. Vancouver, BC: Douglas \& McIntyre.

Swisher, K. (1986). Authentic research: An interview on the way to the Ponderosa. Anthropology \& Education Quarterly, 17(3), 185-188.

Taku River Tlingit First Nation v. British Columbia (Project Assessment Director). (2004). 3 S.C.R. 550, 2004 SCC 74. Retrieved from https://scc-csc.lexum.com/scc-csc/scccsc/en/item/2190/index.do

Ten Fingers, K. (2005). Rejecting, revitalizing, and reclaiming: First Nations work to set the direction of research and policy development. Canadian Journal of Public Health, 96(1), (s60-s64).

Thistle, P. C. (1986). Indian-European Trade Relations in the Lower Saskatchewan River Region to 1840. Winnipeg, MB: University of Manitoba Press. 
Timpson, A. M. (2006). Stretching the concept of representative bureaucracy: The case of Nunavut. International Review of Administrative Sciences, 72(4), 517-530. doi: $10.1177 / 0020852306070081$

Tootoosis, E. (1975). The Plains Cree remember. In Proceedings of the Plains Cree conference. Regina, SK: Canadian Plains Research Centre.

Tough, F. J. (2004). The forgotten constitution: The natural resources transfer agreements and Indian livelihood rights, CA. 1925-1933. Alberta Law Review, 41(4), 999-1048.

Townshend, R. (2013). The case for Native sovereignty. In M. Charlton \& P. Barker (Eds.), Crosscurrents: Contemporary political issues (7th ed., pp. 38-43). Toronto, ON: Nelson Education Ltd.

Treaty Relations Commission of Manitoba. (2016). Manitoba treaties oral history project treaty Elders'teachings series. Winnipeg, MB: Treaty Relations Commission of Manitoba. Retrieved from http://www.trcm.ca/research/completed-research-projects/manitobatreaties-oral-history-project-treaty-elders-teachings-series/

Troian, M. (2016, March 3). 20 years since Royal Commission on Aboriginal Peoples, still waiting for change. CBC News. Retrieved from http://www.cbc.ca/news/indigenous/20year-anniversary-of-rcap-report-1.3469759

Truth and Reconciliation Commission of Canada. (2012). Canada, Aboriginal peoples, and residential schools: They came for the children. Winnipeg, MB: Truth and Reconciliation Commission of Canada. Retrieved from http://www.myrobust.com/websites/trcinstitution/File/2039_T\&R_eng_web[1].pdf Truth and Reconciliation Commission of Canada. (2015). Honouring the truth, reconciling for the future: Summary of the final report of the truth and reconciliation commission of 
Canada. Winnipeg, MB: Truth and Reconciliation Commission of Canada. Retrieved from

http://www.trc.ca/websites/trcinstitution/File/2015/Honouring_the_Truth_Reconciling_fo r_the_Future_July_23_2015.pdf

Tsawwassen First Nation. (2007). Tsawwassen First Nation Final Agreement. Retrieved from https://www.aadnc-aandc.gc.ca/DAM/DAM-INTER-BC/STAGING/textetext/tfnfa_1100100022707_eng.pdf

Tsilhqot'in Nation v. British Columbia. 44 SCC. (2014). 2 S.C.R. 256. Retrieved from https://scc-csc.lexum.com/scc-csc/scc-csc/en/item/14246/index.do

Tssessaze, G. (2007). Eh chet tay (A way of Life): Re-indigenizing the governance of Lac Brochet (Masters Thesis). Retrieved from ProQuest.

Tuck, E., \& Yang, K. W. (2012). Decolonization is not a metaphor. Decolonization: Indigeneity, Education \& Society, 1(1), 1-40.

Tully, J. (1995). Strange multiplicity: Constitutionalism in an age of diversity. Cambridge, UK: Cambridge University Press.

Turner, D. (2007). This is not a peace pipe: Towards a critical Indigenous philosophy. Toronto, ON: University of Toronto Press.

Turpel, M. E., \& Monture, P. A. (1990). Ode to Elijah: Reflections of two First Nations women on the rekindling of spirit at the wake for the Meech Lake accord. Queen's Law Journal, 15(1-2), 345-359. Retrieved from http://www.heinonline.org.ezproxy.lib.ryerson.ca/HOL/Page?page=345\&handle=hein.jou rnals $\% 2$ Fqueen $15 \&$ collection $=$ journals 
Union of British Columbia Indian Chiefs. (1970). A declaration of Indian rights: The B.C. Indian position paper. Vancouver BC: Union of British Columbia Indian Chiefs.

United Nations. (2007). United Nations declaration on the rights of Indigenous peoples. New York, NY: United Nations. Retrieved from http://www.un.org/esa/socdev/unpfii/documents/DRIPS_en.pdf

United Nations. (2016). Charter of the United Nations. New York, NY: United Nations. Retrieved from http://www.un.org/en/charter-united-nations/index.html

United Nations. (2017). Permanent Forum. New York, NY: United Nations. Retrieved from https://www.un.org/development/desa/indigenouspeoples/unpfii-sessions-2.html

University of Victoria. (2003). Protocols \& principles for conducting research in an Indigenous context. Victoria, BC: University of Victoria. Retrieved from http://web.uvic.ca/igov/uploads/pdf/Indigenous\%20Research\%20Protocols.pdf

University of Victoria. (2013). Indigenous governance (Masters). Victoria, BC: University of Victoria. Retrieved from http://www.uvic.ca/graduatestudies/programs/home/programdescriptions/programs/indige nous-governance-ma.php

Venne, S. H. (1981). Indian Acts and amendments 1868-1975, an indexed collection. Saskatoon, SK: University of Saskatchewan Native Law Centre.

Venne, S. (1997). Understanding treaty 6: An Indigenous perspective. In M. Asch (Ed.), Aboriginal and treaty rights in Canada essays on law, equality, and respect for difference (pp. 173-207). Vancouver, BC: UBC Press.

Venne, S. (1998). Our elders understand our rights: Evolving international law regarding Indigenous rights. Pentiction, BC: Theytus Books Ltd. 
Venne, S. (2016, March). Think Indigenous. Key note presented at the Think Indigenous Conference. Retrieved from https://www.youtube.com/watch?list=PLQptLdMDrox31_bEJcmmUqpsiIW_cudDY\&ti me_continue $=6 \& \mathrm{v}=8$ Empry6oros

Viatori, M. S., \& Ushigua, G. (2007). Speaking sovereignty: Indigenous languages and selfdetermination. Wicazo Sa Review, 22(2), 7-21. doi: 10.1353/wic.2007.0022

von der Porten, S. (2012). Canadian Indigenous governance literature: A review. AlterNative: An International Journal of Indigenous Peoples, 8(1), 1-14.

Wachhaus, A. (2009). Networks in contemporary public administration: A discourse analysis. Administrative Theory \& Praxis, 31(1), 59-77.

Wakeham, P. (2014). At the intersection of apology and sovereignty: The Arctic exile monument project. Cultural Critique, 84, 84-143. Retrieved from Project Muse.

Waldo, D. (1948). The administrative state: A study of the political theory of American public administration. New York, NY: Ronald Press.

Wallace, S. (2012). Prince Albert Grand Council hosting NRTA national summit. Retrieved from http://ckom.com/article/180638/prince-albert-grand-council-hosting-nrta-national-summit Wastesicoot J. (2004). A cultural framework for Cree self-government: Retracing our steps back (Master's Thesis). Retrieved from https://mspace.lib.umanitoba.ca/xmlui/bitstream/handle/1993/3831/Wastesicoot\%2c\%20 A\%20Cultural.pdf?sequence $=1 \&$ isAllowed $=y$

Wastesicoot, J. (2015). Tapwetamowin: Cree spirituality and law for self-governance (Doctoral Dissertation). Retrieved from https://mspace.lib.umanitoba.ca/xmlui/handle/1993/30319 
Weaver, S. (1997). An assessment of the Federal self-government policy. In A. Morrison and I. Cotler (Eds.), Justice for Natives: Searching for common ground (pp. 111-117). Montreal, QC: McGill-Queen's University Press.

Weaver, S. M. (1984). Indian government: A concept in need of a definition. In Littlebear, L., Boldt, J., \& Long, A. (Eds.), Pathways to self-determination: Canadian Indians and the Canadian state (pp. 65-68). Toronto, ON: University of Toronto.

Wheeler, W. (2010). Cree intellectual traditions in history. In A. Finkle, S. Carter, \& P. Fortna, (Eds.), The West and beyond: New perspectives on an imagined region (pp. 47-61). Edmonton, AB: Athabasca University Press.

White, G. (2006). Traditional aboriginal values in a Westminster parliament: The legislative assembly of Nunavut. The Journal of Legislative Studies, 12(1), 8-31. Retrieved from http://journals1.scholarsportal.info/pdf/13572334/v12i0001/8_taviawptlaon.xml

Wildlife Conservation Society. (2016). The buffalo: A treaty of cooperation, renewal, and restoration. Bozeman MT: Wildlife Conservation Society. Retrieved from https://programs.wcs.org/Portals/175/Documents/The\%20Buffalo\%20Treaty_2014.pdf?v er=2016-01-29-184835-080

Wilkins, D. E., \& Stark, H.K. (2011). American Indian politics and the American political system ( $3^{\text {rd }}$ Ed.). Lanham, MD: Rowman \& Littlefield Publishers Inc.

Williams, R. A. (1993). The American Indian in Western legal thought: The discourses of conquest. Oxford, UK: Oxford University Press.

Wilson, A. M. (2007). N'tacimowin inna nah': Coming in to two-spirit identities. (Doctoral Dissertation). Retrieved from ProQuest. 
Wilson, L. S. (1989). Cultural conflict and academic achievement of Cree Indian students: perceptions of schooling from Opasquia Ininiwuk. (Doctoral Dissertation). Retrieved from ProQuest.

Wilson, S. (2001). What is Indigenous research methodology? Canadian Journal of Native Eduction, 25(2), 175-179. Retrieved from ProQuest.

Wilson, S. (2008). Research is ceremony: Indigenous research methods. Halifax, NS: Fernwood Publishing.

Wolvengrey, A. E. (2011). Semantic and pragmatic functions in Plains Cree syntax (Doctoral Dissertation). Utrecht: LOT.

Wotherspoon, T., \& Hansen, J. (2013). The "Idle No More" movement: Paradoxes of First Nations inclusion in the Canadian context. Social Inclusion, 1(1), 21-36.

York, G., \& Pindera, L. (1991). People of the pines: The warriors and the legacy of Oka. Boston MA: Little Brown \& Co.

Zacher, M. W. (2001). The territorial integrity norm: International boundaries and the use of force. International Organization, 55(2), 215-250. doi:10.1162/00208180151140568

Zraly, M., Mugengana, J. P., \& Walton, R. (2015). Values and validity: Navigating messiness in a community-based research project in Rwanda. Technical Communication Quarterly, 24(1), 45-69. doi:10.1080/10572252.2015.975962 